Portland State University

PDXScholar

7-16-2021

\title{
New Perspectives on Prolific and Voluminous Rhyolite Volcanism of the Mahogany Mountain- Three Fingers Rhyolite Field, Eastern Oregon
}

Robert Andrew Jackson

Portland State University

Follow this and additional works at: https://pdxscholar.library.pdx.edu/open_access_etds

Part of the Geochemistry Commons, Geology Commons, and the Stratigraphy Commons Let us know how access to this document benefits you.

\section{Recommended Citation}

Jackson, Robert Andrew, "New Perspectives on Prolific and Voluminous Rhyolite Volcanism of the Mahogany Mountain--Three Fingers Rhyolite Field, Eastern Oregon" (2021). Dissertations and Theses. Paper 5770.

https://doi.org/10.15760/etd.7641

This Thesis is brought to you for free and open access. It has been accepted for inclusion in Dissertations and Theses by an authorized administrator of PDXScholar. Please contact us if we can make this document more accessible: pdxscholar@pdx.edu. 
New Perspectives on Prolific and Voluminous Rhyolite Volcanism of the Mahogany Mountain—-Three Fingers Rhyolite Field, Eastern Oregon

by

Robert Andrew Jackson

A thesis submitted in partial fulfillment of the requirements of the degree of

\author{
Master of Science \\ in \\ Geology
}

Thesis Committee:

Martin J. Streck, Chair

Alex Ruzicka

John Bershaw

Portland State University

2021 


\begin{abstract}
Voluminous silicic volcanism of the Mahogany Mountain-Three Fingers rhyolite field (MM-TFrf) is spatially and temporally associated with mid-Miocene flood basalts of the Columbia River Basalt province. Early studies of the area advocated for a two-caldera model consisting of the Mahogany Mountain and the slightly younger Three Fingers caldera with pre- and post-caldera effusive rhyolite eruptions. Although close in time, the calderas were thought to be spatially offset producing the tuff of Leslie Gulch and the tuff of Spring Creek. Finding that the tuff of Spring Creek, that is exposed in Leslie Gulch, is an altered product of the tuff of Leslie Gulch, Benson \& Mahood (2016) suggested only one large caldera with pre- to post-caldera lavas. With the new data of my study, building on results by Marcy (2013), we can address key outstanding questions regarding the stratigraphic and geochemical evolution of mid-Miocene rhyolite volcanism at the MMTFrf. Abundant and compositionally variable effusive rhyolites largely postdate the tuff of Leslie Gulch, including the Mahogany Mountain as well as the McIntyre Ridge rhyolite that were considered pre-caldera before. New ages of the Mahogany Mountain rhyolite suite (15.82-15.71 Ma) and stratigraphic, mineral \& compositional data, and age relationships along Succor Creek indicate both rhyolites are post-caldera. The only rhyolite underlying the tuff of Leslie Gulch was identified in the Leslie Gulch locality itself, yielding an age of 16.02 Ma. Stratigraphic data reveal that the tuff of Leslie Gulch is a complex, multi-phase deposit with eruptive breaks in between. There are additional discrete explosive events with deposits along Succor Creek and north of Leslie Gulch that are distinguished by age or composition. Similarly, geochronological and compositional data can be used to identify distinct post-caldera rhyolite magmas. In summary, the
\end{abstract}


MM-TFrf represents a prolific rhyolite center that was active from 16.02 to $15.71 \mathrm{Ma}$ thus shifting initiation of rhyolite activity back, to the end of Grande Ronde Basalt volcanism. Rhyolite eruptions recommenced in the SW of the field with the eruption of the 14.94 Ma Birch Creek rhyolite, and 14.42 Ma McCain Creek rhyolite. 


\section{ACKNOWLEDGEMENTS}

Martin Streck has been an outstanding advisor; I am truly grateful for his continuous support and patience. He has been crucial to the success of this project and my progress as a graduate student, and I am truly thankful. I would like to thank my family, especially my father who originally prompted my pursuit of geology. I thank my cohort at Portland State University who provided constant support and encouragement throughout this journey. I thank my thesis committee-Martin Streck, Alex Ruzicka, and John Bershaw — who reviewed and revised my work. I would like to thank Michael Cummings for his knowledge and work in southeast Oregon. I thank Rick Hugo for his expertise and patience with the scanning electron microscope and assistance with data acquisition for this project. I thank Dr. Ilya Bindeman for his direction, patience and assistance with the $\delta^{18} \mathrm{O}$ stable isotope analysis. I thank the Oregon State University Geochronology Laboratory for their help with ${ }^{40} \mathrm{Ar} /{ }^{39} \mathrm{Ar}$ dating. I thank Mike Greeley for giving access to his property on Mahogany Mountain, which provided crucial evidence to this project. Lastly, I thank my field assistants Paul Gerber, Charlie Carr, Nick Roberts, and Vanessa Swenton, who helped keep us safe and acquire the samples of this study. It takes a village. 


\section{TABLE OF CONTENTS}

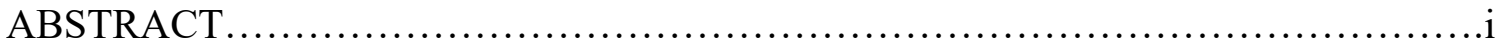

ACKNOWLEDGEMENTS.................................................ii

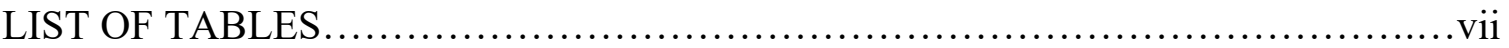

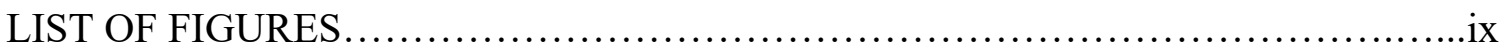

CHAPTER 1: INTRODUCTION ..............................................

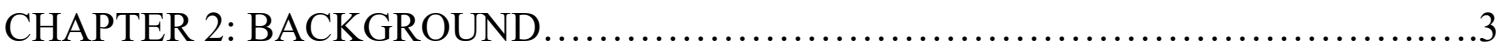

Accreted Terranes....................................................... 3

Columbia River Magmatic Province.........................................5

The Lake Owyhee Volcanic Field ........................................ 8

The Oregon-Idaho Graben.............................................. 10

Previous Studies of the Mahogany Mountain_-Three Fingers Rhyolite Field.....12

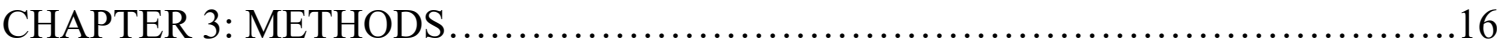

CHAPTER 4: RESULTS .........................................................

New Ages for Rhyolites of Mahogany Mountain — Three Fingers Rhyolite

Field..................................................................... 19

Eruptive Stratigraphy of the Mahogany Mountain-Three Fingers Rhyolite

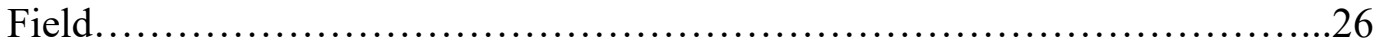

Overview....................................................26

Composite Tuff of Leslie Gulch.................................30

Rhyolite SE of Round Mountain.....................................37

The Mahogany Mountain Rhyolite Suite..............................41

Bannock Ridge Rhyolite.........................................54 


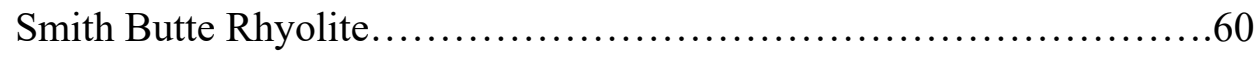

Birch Creek Rhyolite................................................63

McCain Creek Rhyolite.............................................69

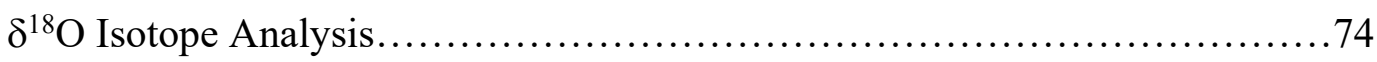

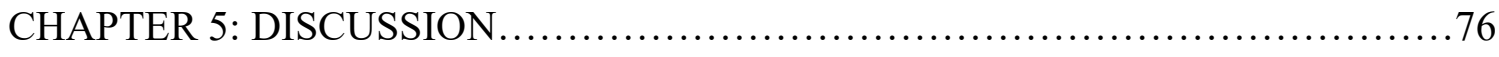

Inferences of ages for $\mathrm{MM}-\mathrm{TF}$ rhyolite field.............................. 76

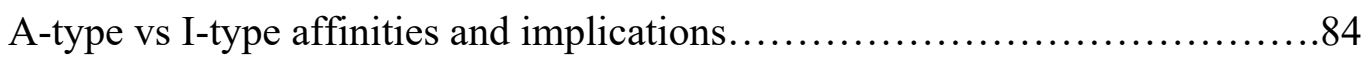

$\delta^{18} \mathrm{O}$ Isotopes for Mahogany Mountain —-Three Fingers rhyolites...............87

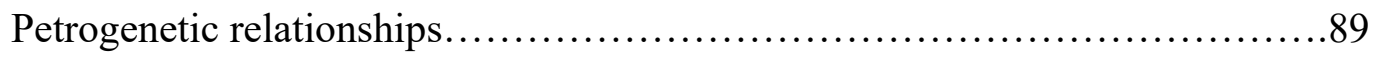

Evolution within the Mahogany Mountain rhyolites....................91

Derivation of Mahogany Mountain rhyolites from Leslie Gulch magma

Relationships amongst post-caldera rhyolites.........................95

Rhyolite Generation at the Mahogany Mountain—Three Fingers rhyolite

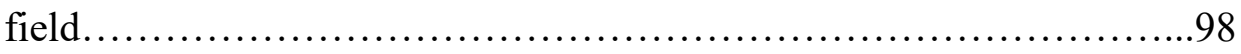

Stratigraphy \& Oregon-Idaho graben development....................101

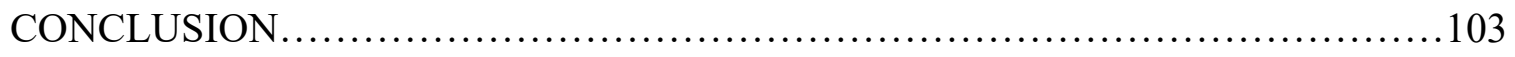

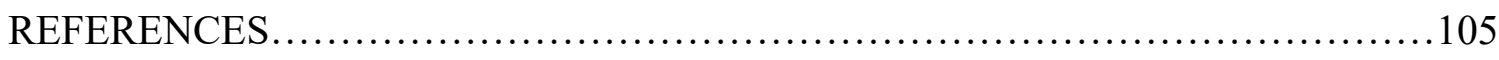

APPENDIX A: ${ }^{40} \mathrm{Ar} /{ }^{39} \mathrm{Ar}$ Dating of Rhyolite Lavas.................................111

APPENDIX B: Thin Sections of Rhyolite Units.................................118

APPENDIX C: X-Ray Fluorescence (XRF) Chemical Data...........................130

APPENDIX D: Inductively Coupled Plasma-Mass Spectrometry (ICP-MS) Chemical

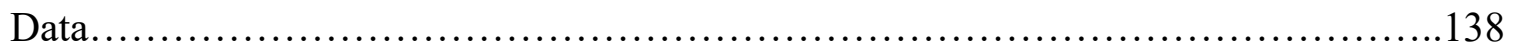




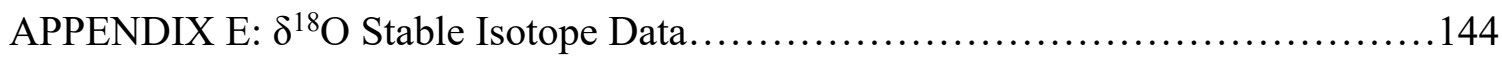

APPENDIX F: Scanning Electron Microscopy with Energy Dispersive X-ray

Spectrometry (SEM-EDX) Chemical Data...................................... 147

APPENDIX G: Geologic Map with sample locations..............................155

APPENDIX H: Partition Coefficients used in geochemical modeling..................156 


\section{LIST OF TABLES}

Table 1. Total fusion ${ }^{40} \mathrm{Ar} /{ }^{39} \mathrm{Ar}$ dates for the glassy rhyolite SE of Round Mt., three flows of the MMR, and the McCain Creek rhyolite. See appendix for sample locations and detailed results of ${ }^{40} \mathrm{Ar} /{ }^{39} \mathrm{Ar}$ sample analyses. Materials dated include plagioclase and sanidine denoted by ' $\mathrm{P}$ ' and ' $\mathrm{S}$ ', respectively. Data in the grey shade are the preferred

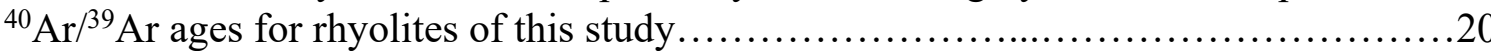

Table 2. The average, minimum, and maximum calculated end-member compositions from scanning electron microscope (SEM-EDX) analyses of Leslie Gulch ash-flow tuff feldspar phenocrysts. Ash-flow tuff sample number: RJ-18-28......................35

Table 3. The average, minimum, and maximum calculated feldspar components from scanning electron microscope (SEM-EDX) data of 'rhyolite SE of Round Mtn' feldspar phenocrysts. 'Rhyolite SE of Round Mtn sample number: RJ-18-05 ..................38

Table 4. The average, minimum, and maximum calculated end-member compositions from scanning electron microscope (SEM-EDX) analyses of 'Rhyolite SE of Round Mtn' pyroxene phenocrysts. 'Rhyolite SE of Round Mtn' sample number: RJ-18-05 ..........39

Table 5. The average, minimum, and maximum calculated feldspar components from scanning electron microscope data of Mahogany Mtn rhyolite feldspar phenocrysts. Rhyolite samples were grouped by flow: flow unit 1 , flow unit $2, \&$ flow unit $3 \ldots \ldots \ldots . .51$

Table 6. The average, minimum, and maximum calculated pyroxene components from scanning electron microscope and electron microprobe data of MMR pyroxene phenocrysts. Rhyolite samples were grouped by flow: flow unit 1 , flow unit $2, \&$ flow

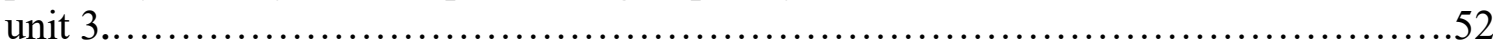

Table 7. The average, minimum, and maximum calculated feldspar components from scanning electron microscope data of Bannock Ridge Rhyolite feldspar phenocrysts. Bannock Ridge Rhyolite sample number: RJ-18-02 \& RJ-18-02A......................57

Table 8 . The average, minimum, and maximum calculated pyroxene components from electron microprobe data of Bannock Ridge rhyolite pyroxene phenocrysts. Bannock

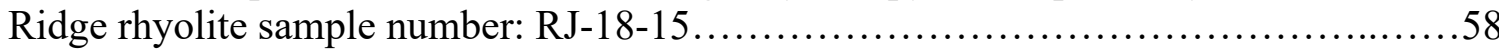

Table 9. The average, minimum, and maximum calculated feldspar components from scanning electron microscope data of Smith Butte Rhyolite feldspar phenocrysts. Smith Butte Rhyolite sample number: RJ-18-04.......................................61

Table 10. The average, minimum, and maximum calculated feldspar components from scanning electron microscope data of Birch Creek rhyolite feldspar phenocrysts. Birch Creek rhyolite sample number: RJ-18-32 \& RJ-18-35 .............................67 
Table 11. The average, minimum, and maximum calculated feldspar components from scanning electron microscope data of McCain Creek Rhyolite feldspar phenocrysts.

McCain Creek Rhyolite sample number: RJ-18-53 \& RJ-18-57........................71

Table 12. The average, minimum, and maximum calculated pyroxene components from electron microprobe data of McCain Creek rhyolite pyroxene phenocrysts. McCain Creek

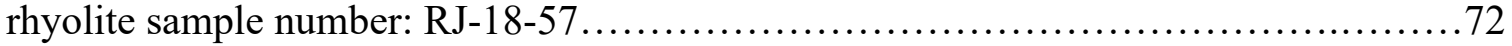

Table 13. Oxygen isotopic compositions acquired from this study. The magmatic $\delta^{18} \mathrm{O}$ values were calculated using equations D-1, D-2, and D-3 as detailed in Appendix E....74

Table $14 .{ }^{40} \mathrm{Ar} /{ }^{39} \mathrm{Ar}$ age data for rhyolites of the Mahogany Mountain-Three Fingers rhyolite field. Age data presented consists of ${ }^{1}$ : samples of this study, ${ }^{2}$ : Streck \& others., 3. Swenton (unpub.), ${ }^{4}$ : Marcy (2013), ${ }^{5}$ : Hess, (2014), ${ }^{6}$ : Benson \& Mahood (2016),

7: Black (2021)............................................................. 


\section{LIST OF FIGURES}

Figure 1. Sketch map showing major Paleozoic-Mesozoic age terrane boundaries in eastern Oregon and western Idaho. Major Mesozoic, Late Jurassic to Early Cretaceous age, intrusions in northeast Oregon are displayed in green. The Mahogany MountainThree Fingers rhyolite field (MM-TFrf) is shown in the orange polygon within the OIG grey shaded area. Regional features depicted are denoted by the following abbreviations: BB, Bald Mountain Batholith; BG, Baker Graben; BT, Baker terrane; CCF, Connor Creek Fault; CJD, Chief Joseph Dike Swarm; LG, La Grande graben; NVF, northern Nevada volcanic field; OIG, Oregon-Idaho graben; OIT, Olds Ferry-Izee terrane; PGD, Picture Gorge dike swarm; SD, Steens Mountain dike swarm; SM, Strawberry Mountain; WB, Wallowa Batholith; WSRP, Western Snake River Plain; WT, Wallowa terrane. Modified from Ferns et al., 2017. ...............................................

Figure 2. Map showing the areal extent of the Columbia River flood basalt province, in shaded area. Figure from Reidel et al. (2013) ......................................

Figure 3. Regional map displaying the areal extents of the Columbia River basalts, as well as contemporaneous rhyolitic centers. The Oregon-Idaho graben is marked by the thick black lines. The Lake Owyhee volcanic field (LOVF) is delineated by the crosshatched polygon. The Mahogany Mountain - Three Fingers rhyolite field (MM-TFrf) is shown in the southeast of the volcanic field. This figure was modified from Benson et al., (2016).

Figure 4. Regional map of the Mahogany Mountain-Three Fingers rhyolite field showing the approximate caldera margins of the Mahogany Mountain and Three Fingers calderas from Rytuba et al., (1991), and the Rooster Comb caldera from Benson \& Mahood (2016). Modified from Ferns (1993) 1:100,000 scale geology map. The yellow-dashed box indicates the extent of this study .................................................

Figure 5. Ideogram of ${ }^{40} \mathrm{Ar} /{ }^{39} \mathrm{Ar}$ dating results for the 'Rhyolite SE of Round Mtn' yielding an age of $15.83 \pm 0.03 \mathrm{Ma}$, sample number: RJ-18-05. The red line signifies age estimates for individual crystals of this sample. The purple line signifies the probability density curve based on age estimates for crystals of the sample.

Figure 6. Ideogram of ${ }^{40} \mathrm{Ar} /{ }^{39} \mathrm{Ar}$ dating results for the Mahogany Mountain rhyolite, flow unit 1, yielding an age of $15.81 \pm 0.02 \mathrm{Ma}$. Sample number: RJ-18-11. The red line signifies age estimates for individual crystals of this sample. The purple line signifies the probability density curve based on age estimates for crystals of the sample .22 
Figure 7. Ideogram of ${ }^{40} \mathrm{Ar} /{ }^{39} \mathrm{Ar}$ dating results for the Mahogany Mountain rhyolite, flow unit 2, yielding an age of $15.82 \pm 0.05 \mathrm{Ma}$. Sample number: RJ-18-50. The red line signifies age estimates for individual crystals of this sample. The purple line signifies the probability density curve based on age estimates for crystals of the sample.... 23

Figure 8. Ideogram of ${ }^{40} \mathrm{Ar} /{ }^{39} \mathrm{Ar}$ dating results for the Mahogany Mountain rhyolite, flow unit 3, yielding an age of yielding an age of $15.71 \pm 0.03 \mathrm{Ma}$. Sample number: RJ-18-03. The red line signifies age estimates for individual crystals of this sample. The purple line signifies the probability density curve based on age estimates for crystals of the sample...

Figure 9. Ideogram of ${ }^{40} \mathrm{Ar} /{ }^{39} \mathrm{Ar}$ dating results of the McCain Creek rhyolite yielding an age of $14.43 \pm 0.02 \mathrm{Ma}$. Sample number: RJ-18-57...........................24

Figure 10. Age plot for ${ }^{40} \mathrm{Ar} /{ }^{39} \mathrm{Ar}$ dating results for rhyolite lavas of this study. Shaded area represents the duration of tuff of Leslie Gulch units (Streck \& McIntosh, in prep.)..................................................................25

Figure 11. Geologic map generated by mapping extents of rhyolite units within the study area, and created using Arcmap 10.6. Faults are based on from Ferns et al. (1993). The dashed line marks the Succor Creek Road and Leslie Gulch Road. Caldera margin is drawn based on the presence of intra-caldera tuff of Leslie Gulch and post-caldera rhyolite units, as well as the topographic high of Mahogany Mtn. Map projection and datum are North American Datum 1983. ........................................ 28

Figure 12. Trace element bivariate plots for Mahogany Mountain-Three Fingers rhyolites. ${ }^{1}$ : samples of this study. ${ }^{2}$ : samples of Streck \& others. ${ }^{3}$ : samples of Swenton, unpub. ${ }^{4}$ : samples of Marcy, 2013. ${ }^{5}$ : samples of Hess, 2014 ........................29

Figure 13. Photograph of composite tuff of Leslie Gulch outcrop featuring an ash-flow tuff member overlying and capping air-fall facies (A). Image B is a closer view of ashflow tuff member. Location of sample RJ-18-28, ash-flow tuff component of composite tuff of Leslie Gulch.............................................................. 31

Figure 14. Photograph of ash-flow tuff sample number RJ-18-28, depicting clast supported matrix and underlying fall-out facies................................. 32

Figure 15. Photomicrographic image of ash flow tuff member of the composite tuff of Leslie Gulch in thin section, sample: RJ-18-28. To the left, is the stratigraphically lower and more fragmented ash layer, and to the right is the overlying ash-flow tuff layer......33

Figure 16. Photomicrographic image of ash-flow tuff member of the composite tuff of Leslie Gulch. In view are fragmented feldspars phenocrysts within a pyroclastic matrix 
Figure 17. Ternary plot displaying the range of calculated end-member compositions from scanning electron microscope (SEM) analyses of feldspar phenocrysts of the composite tuff of Leslie Gulch samples. Ash-flow tuff sample number: RJ-18-28. . .

Figure 18. Trace element concentrations for ash-flow tuff sample (RJ-18-28). Sample was normalized to primitive mantle, Sun \& McDonough (1989).

Figure 19. Rare earth element diagram showing samples of the tuff of the Leslie Gulch, normalized to C1 chondrite, McDonough \& Sun (1995). Ash-flow tuff sample: RJ-1828

Figure 20. Photomicrographic image of 'rhyolite SE of Round Mtn' in thin section. In view are phenocrysts of sanidine, quartz, clinopyroxene, and titanomagnetite within a vitrophyric groundmass.

Figure 21. Ternary plot displaying the range of calculated feldspar components from scanning electron microscope data. 'Rhyolite SE of Round Mountain' sample number: RJ-18-05.

Figure 22. Ternary plot displaying the range of calculated end-member compositions from scanning electron microscope (SEM) of 'Rhyolite SE of Round Mtn' pyroxene

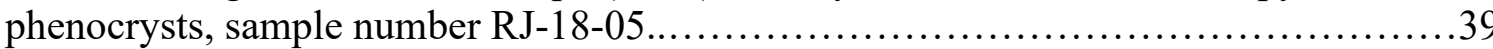

Figure 23. Trace element concentrations for the 'rhyolite SE of Round Mtn', sample number: RJ-18-05. Samples were normalized to primitive mantle, Sun \& McDonough (1989)

Figure 24. Rare earth element concentrations for 'rhyolite SE of Round Mtn' lava sample normalized to C1 chondrite, McDonough \& Sun (1995). 'Rhyolite SE of Round Mtn' sample number: RJ-18-05

Figure 25. Image A shows a stratigraphic view of the north face of Mahogany Mountain, displaying Flow 3 of the Mahogany Mtn Rhyolite overlying tuffaceous intra-caldera sediments. Image B shows an enlarged view of the vertical spines extruded along caldera ring fractures. Image $\mathrm{C}$ displays clasts of glassy rhyolite within the basal breccia of the Mahogany Mountain rhyolite, with a sledgehammer for scale.

Figure 26. Image A shows two spiny domes of Mahogany Mountain rhyolite vertically extruded into intra-caldera lake sediments, with adjacent vitrophyres; view is looking northeast. Image B shows a closer stratigraphic view of the spiny rhyolite dome with near vertical flow banding, view is looking north. 
Figure 27. Image A displays the stratigraphy of the MMR dome on the northeast flank of the mountain with outcrops of vitrophyre and the approximate contact with underlying tuffaceous sediments. Image B displays an outcrop featuring columnar-jointing and flow banding within the MMR vitrophyre. Image $C$ displays an additional outcrop featuring columnar-jointing within MMR vitrophyre. A $4 \mathrm{lb}$. sledgehammer is used for scale in Images B \& C

Figure 28. Photomicrographs of sample RJ-18-11 of the Mahogany Mountain rhyolite, Flow Unit 1, in thin section. Top image is displayed in plane-polarized light and the bottom image is displayed in cross-polarized light. In view are phenocrysts of Oligoclase, clinopyroxene, titanomagnetite, and accessory apatite and zircon within a vitrophyric groundmass. Spherulites are present as secondary product within the groundmass.

Figure 29. Photomicrographs of sample RJ-18-19 of the Mahogany Mountain rhyolite, flow unit 3 , in thin section. Top image is displayed in plane-polarized light and the bottom image is displayed in cross-polarized light. In view are phenocrysts of sanidine, clinopyroxene, titanomagnetite, and accessory apatite and zircon within a vitrophyric groundmass.

Figure 30. Bivariate plot of $\mathrm{SiO}_{2}$ (wt. \%) vs Barium (ppm) for flow units of the Mahogany Mtn rhyolite. Here we can see the Mahogany Mountain rhyolite in red circles, show depletion in Ba concentration with successive flow units and increasing silica content.

Figure 31 . Ternary plot displaying the range of calculated feldspar components from scanning electron microscope data of Mahogany Mountain rhyolite feldspar phenocrysts. Feldspars of flow unit 1 are shown in red, flow unit 2 in purple, and flow unit 3 in blue.

Figure 32. Ternary plot displaying the range of calculated pyroxene components from scanning electron microscope (SEM) and electron microprobe analyses of Mahogany Mountain rhyolite pyroxene phenocrysts. Pyroxenes of flow unit 1 are shown in red, flow unit 2 in purple, and flow unit 3 in blue.

Figure 33. Trace element concentrations of Mahogany Mountain rhyolite samples. Samples of Flow unit 1 are designated as burgundy squares, samples from Flow unit 2 are dark red circles, and samples of Flow unit 3 red diamonds. Samples were normalized to primitive mantle, Sun \& McDonough (1989).

Figure 34. Rare earth element diagram for samples of the Mahogany Mountain rhyolite suite normalized to C1 chondrite of McDonough \& Sun (1995). Samples of flow unit 1 are symbolized with burgundy squares, samples of flow unit 2 are symbolized with dark red circles, and samples of flow unit 3 symbolized with red diamonds.... 
Figure 35. Photomicrographs of sample RJ-18-15 of the Bannock Ridge rhyolite, in thin section. Top image is displayed in plane-polarized light and the bottom image is displayed in cross-polarized light. In view are phenocrysts of sanidine, clinopyroxene, titanomagnetite, and accessory apatite and zircon within a vitrophyric groundmass.....56

Figure 36. Ternary plot displaying the range of calculated feldspar components from scanning electron microscope data of Bannock Ridge rhyolite feldspar phenocrysts. Feldspars display compositions ranging from Oligoclase $\left(\mathrm{An}_{20-18} \mathrm{Ab}_{74-71} \mathrm{Or}_{11-9}\right)$ to Anorthoclase $\left(\mathrm{An}_{13-8} \mathrm{Ab}_{71-66} \mathrm{Or}_{26-15}\right)$. Bannock Ridge rhyolite samples: RJ-18-02 \& RJ-

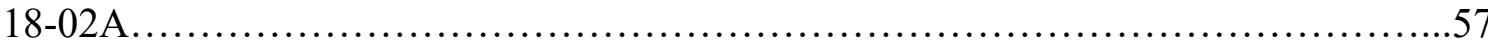

Figure 37. Ternary plot displaying the range of calculated pyroxene components from electron microprobe data of Bannock Ridge rhyolite pyroxene phenocrysts. Bannock Ridge rhyolite samples RJ-18-02 \& RJ-18-15.

Figure 38. Trace element concentrations of Bannock Ridge rhyolite samples: RJ-18-02 \& RJ-18-15. Samples have been normalized to primitive mantle composition, Sun \& McDonough (1989) .............................................................

Figure 39. Rare earth element diagram of Bannock Ridge rhyolite samples normalized to C1 chondrite, McDonough \& Sun (1995).

Figure 40. Ternary plot displaying the range of calculated feldspar components from scanning electron microscope data of Smith Butte rhyolite feldspar phenocrysts. Feldspars display sanidine compositions ( $\left.\mathrm{An}_{3-1} \mathrm{Ab}_{50-47} \mathrm{Or}_{51-47}\right)$. Smith Butte rhyolite sample: RJ-18-04.

Figure 41. Trace element concentrations of Smith Butte rhyolite sample number: RJ-1804. Samples were normalized to primitive mantle, Sun \& McDonough (1989)....

Figure 42. Rare earth element concentrations for Smith Butte rhyolite sample normalized to $\mathrm{C} 1$ chondrite, McDonough \& Sun (1995). Smith Butte rhyolite sample: RJ-18-04...62

Figure 43. Image A is photograph of the Birch Creek rhyolite lava with glassy rhyolite columns exposed on the extents of a dome. Image B displays lithology of the of the rhyolite lava in cross-sectional view.

Figure 44. Image A displays view of Birch Creek rhyolite dome with vitrophyre rind exposed. Image $\mathrm{B}$ is a closer view of the stratigraphy present along the ridge. Image $\mathrm{C}$ gives a view of the glassy-devitrified transition zone, with flow banding observed. Ritein-the-rain notebook for scale.

Figure 45. Petrographic images of the Birch Creek rhyolite lava, in plane-polarized light on the left, and cross-polarized light on the right. In view are glomerocrysts of plagioclase, biotite, hornblende, and magnetite .66 
Figure 46. Ternary plot displaying the range of calculated feldspar components from scanning electron microscope data of Birch Creek rhyolite feldspar phenocrysts. Feldspars display compositions ranging from Labradorite $\left(\mathrm{An}_{55} \mathrm{Ab}_{43} \mathrm{Or}_{2}\right)$ to Oligoclase compositions (An $\left.28-29 \mathrm{Ab}_{63-64} \mathrm{Or}_{7-8}\right)$. Birch Creek rhyolite samples: RJ-18-32 \& RJ-1835

Figure 47. Trace element concentrations of the Birch Creek Rhyolite normalized to primitive mantle composition, Sun \& McDonough (1989). Birch Creek rhyolite samples:

Figure 48. Rare earth element concentrations for Birch Creek rhyolite lava samples, normalized to C1 chondrite, McDonough \& Sun (1995). Birch Creek rhyolite sample numbers: RJ-18-32 \& RJ-18-35.

Figure 49. Photomicrographs of sample RJ-18-57 of the McCain Creek rhyolite, in thin section. In view are phenocrysts of Oligoclase, sanidine, clinopyroxene, titanomagnetite, and accessory apatite and zircon within a vitrophyric groundmass $\ldots \ldots \ldots \ldots \ldots \ldots \ldots . . .70$

Figure 50. Ternary plot displaying the range of calculated feldspar components from scanning electron microscope data of McCain Creek rhyolite feldspar phenocrysts. Feldspars display compositions ranging from Andesine $\left(\mathrm{An}_{55} \mathrm{Ab}_{43} \mathrm{Or}_{2}\right)$ to Sanidine compositions (An $28-29 \mathrm{Ab}_{63-64} \mathrm{Or}_{7-8}$ ). McCain Creek rhyolite samples: RJ-18-53 \& RJ-18-

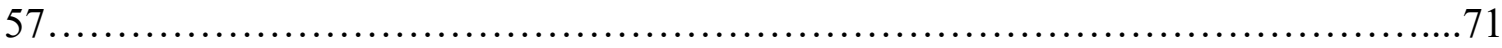

Figure 51. Ternary plot displaying the range of calculated pyroxene components from electron microprobe data of McCain Creek rhyolite pyroxene phenocrysts. McCain Creek rhyolite sample: RJ-18-57.................................................... 72

Figure 52. Trace element concentrations for McCain Creek rhyolite lavas normalized to primitive mantle, Sun \& McDonough (1989). McCain Creek rhyolite samples: RJ-18-53

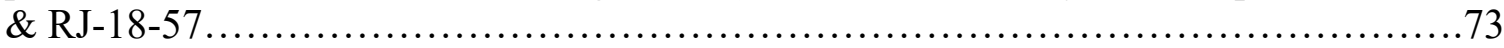

Figure 53. Rare earth element concentrations of McCain Creek rhyolite normalized to C1 chondrite, McDonough \& Sun (1995). McCain Creek rhyolite samples: RJ-18-53 \& RJ-

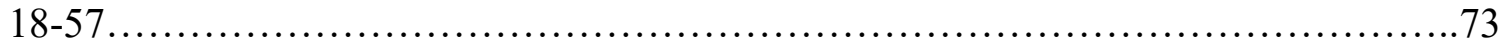

Figure 54. $\delta^{18} \mathrm{O}$ Isotopes for rhyolites of this study, plotted with known age in time. Where applicable, feldspar and quartz phenocryst $\delta^{18} \mathrm{O}$ values are plotted and linked by a dashed or solid line. Feldspars are solid symbols and quartz values are hollow. cTLG refers to composite tuff of Leslie Gulch. Smith Butte rhyolite age data from Benson \& Mahood (2016). 
Figure 55. ${ }^{40} \mathrm{Ar} /{ }^{39} \mathrm{Ar}$ age data for rhyolites of the Mahogany Mountain-Three Fingers rhyolite field. Shaded area depicts the extent of ages for samples of the tuff of Leslie Gulch. Age data presented consists of ${ }^{1}$ : samples of this study, ${ }^{2}$ : Streck \& others., ${ }^{3}$ : Swenton (unpub.), ${ }^{4}$ : Marcy (2013), ${ }^{5}$ : Hess, (2014), ${ }^{6}$ : Benson \& Mahood (2016), ${ }^{7}$ : Black (2021)....

Figure 56. A-type vs I-type plot, showing the characterization of the MM-TF rhyolites based on sums of incompatible elements $\mathrm{Zr}, \mathrm{Ce}, \mathrm{Y}$, and $\mathrm{Nb}$. Birch Creek is the only Itype rhyolite sampled, all other rhyolite units are of A-type affinity. ${ }^{1}$ : samples of this study. ${ }^{2}$ : samples of Streck \& others. ${ }^{3}$ : samples of Swenton, unpub. ${ }^{4}$ : samples of Marcy,

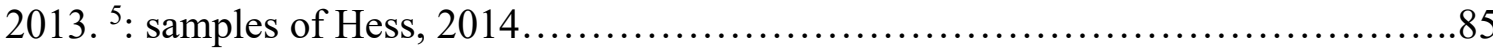

Figure 57. $\delta^{18} \mathrm{O}$ Isotopic values calculated for magmatic values for rhyolites of the MMTFrf plotted with known age in time. Values were calculated from mineral values using equations in Appendix E...................................................... 88

Figure 58. Bivariate plot of $\mathrm{Ba}(\mathrm{ppm}) \mathrm{vs} \mathrm{Nb}(\mathrm{ppm})$, displaying progressive depletion in $\mathrm{Ba}$ and enrichment in $\mathrm{Nb}$, with eruptions of the Mahogany Mountain rhyolite suite and Three Fingers rhyolite. ${ }^{1}$ : units of this study. ${ }^{2}$ : Streck \& others. ${ }^{3}$ : Swenton, unpub. ${ }^{4}$ : Marcy, 2013. ${ }^{5}$ : Hess, 2014.................................................. 90

Figure 59. Fractional crystallization modeling results of a calculated average for the MMR flow unit 1, compared with the average for MMR flow unit 2. Spider diagram has been modified to exclude major elements that could not be modeled, and these results have been normalized to primitive mantle, Sun \& McDonough (1989). . .

Figure 60. Rare earth element diagram of fractional crystallization modeling of MMR flow unit 2, shown to produce similar concentrations to flow unit 3 at 10-20\% fractional crystallization. Samples and modeling results were normalized to $\mathrm{C} 1$ chondrite, McDonough \& Sun (1995)...

Figure 61. Bivariate plot of $\mathrm{Ba}$ vs Eu, displaying feldspar fractionation trends and modeling results for fractional crystallization of successive flows of the MMR. Modeled lines of descent are shown in connected black and grey lines, with degrees of fractional crystallization. Partition coefficients used: $\mathrm{Ba}(7) \& \mathrm{Eu}(4.75) \ldots \ldots \ldots \ldots \ldots \ldots \ldots \ldots . . . \ldots 3$

Figure 62. Fractional crystallization modeling results of tuff of Leslie Gulch, sample number CB-19-67, compared with the average for Mahogany Mountain rhyolite Flow unit 1. Spider diagram has been modified to exclude major elements that could not be modeled, and these results have been normalized to primitive mantle, Sun \& McDonough (1989).

Figure 63. Rare earth element concentrations of the Bannock Ridge rhyolite plotted with averages for Mahogany Mountain rhyolite flow units. Samples are normalized to C1 chondrite, McDonough \& Sun (1995) ........................................... 96 
Figure 64. Fractional crystallization modeling results of the tuff of Leslie Gulch, sample number CB-19-67, compared with the calculated average of the Three Fingers rhyolite. Spider diagram has been modified to exclude major elements that could not be modeled, and these results have been normalized to primitive mantle, Sun $\&$ McDonough

Figure 65. Rhyolite generation model displaying basalts as likely heat source to partially melt crustal material to generate normal to high- $\delta^{18} \mathrm{O}$ signatures. Low- $\delta^{18} \mathrm{O}$ rhyolites are produced through normal faulting and alteration by meteoric waters. Modified from

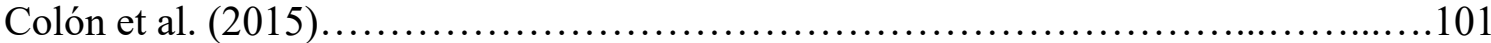




\section{CHAPTER 1: INTRODUCTION}

Mid-Miocene silicic volcanism is widespread and contemporaneous with the main phase of the Columbia River magmatic province. These voluminous eruptive events are thought to be products of bimodal volcanism associated with impingement of the Yellowstone mantle plume on the North American continental lithosphere (Hooper et al., 2002; Coble \& Mahood, 2012). Tholeiitic magmas, generated from the mantle plume, assimilated continental crust in a centralized magma reservoir system between the boundaries of the North American craton and accreted terranes of Idaho and Oregon (Wolff et al., 2008). This magmatic interaction produced eruptions of mafic lavas ranging in composition from basalt to basaltic andesite and silicic lavas dominated by rhyolitic composition. Mafic products consist of the voluminous tholeiitic flood basalt eruptions of the Columbia River Basalt Group, which produced $\sim 230,000 \mathrm{~km}^{3}$ of basalt to basaltic andesite from dike swarms in eastern Oregon, eastern Washington, and western Idaho (Camp et al., 2003). As a result, large volumes $\left(\sim 3,900 \mathrm{~km}^{3}\right)$ of rhyolitic magma were generated, by either partial melting of silicic crustal material or fractional crystallization of tholeiitic magmas, and erupted as ignimbrites and lavas over an area of $\sim 25,000 \mathrm{~km}^{2}$, with the majority of the volume emplaced at the High Rock caldera complex, McDermitt volcanic field, and Lake Owyhee volcanic field (LOVF) (e.g., Coble \& Mahood, 2012).

Silicic volcanism at the LOVF is estimated to account for $\sim 1,115 \mathrm{~km}^{3}$ of the total silicic volume erupted during the main phase of Columbia River basalts and is one of the earliest expressions of silicic volcanism associated with the Snake River PlainYellowstone hotspot (Coble \& Mahood, 2012; Blum et al., 2016). The Mahogany Mountain-Three Fingers rhyolite field (MM-TFrf) accounts for $\sim 25 \%$ of the rhyolitic 
magma erupted within the LOVF and is one of the oldest silicic centers of the volcanic field (Vander Meulen, 1989), playing a key role in illustrating the genesis of silicic volcanism for the LOVF.

The focus of this study is to document the lifespan of hotspot-related rhyolite volcanism at the Mahogany Mountain - Three Fingers rhyolite field in eastern Oregon. Previous studies show inconsistencies with the eruptive history of the rhyolite field and in particular, the Mahogany Mountain rhyolite which accounts for $25 \%$ of all rhyolites of the rhyolite field. Refining the eruptive history of the MM-TFrf is needed to obtain an accurate picture on the timing of rhyolite eruptions at the MM-TFrf and gain insights into the magmatic evolution of the MM-TFrf through time. This study is part of a broader project to determine the extent, duration, and characteristics of silicic volcanism across eastern Oregon which are contemporaneously associated with the Columbia River flood basalts and bimodal province of the High Lava Plains. 


\section{CHAPTER 2: BACKGROUND}

Rhyolite volcanism generated within an intra-continental setting is thought to largely be derived by partial melting of existing country rock. Here I will discuss the regional geology of the area to give context to the existing material from which midMiocene silicic volcanism at the Mahogany Mountain-Three Fingers rhyolite field may have been derived, and then discuss the local geology and more recent volcanism of the area.

\subsection{Accreted Terranes}

The basement of Eastern Oregon is composed of late Paleozoic and early Mesozoic terranes that were accreted via subduction onto the Laurentian margin of North America (Dickinson, 2004). These terranes include, from north to south, the Wallowa terrain, the Baker terrain, and the Olds Ferry-Izee terrain (Fig. 1) (Ferns \& McClaughery, 2013). The three allochthonous crustal blocks are composed of island-arc and oceanic rocks, which are variably faulted and folded, and have been intruded by middle Mesozoic granitic bodies (Dickinson, 2004; Ferns \& McClaughery, 2013). These terranes form a complex suture zone along the North American cratonic margin, which is locally composed of the Idaho Batholith (Hooper et al., 2007). 


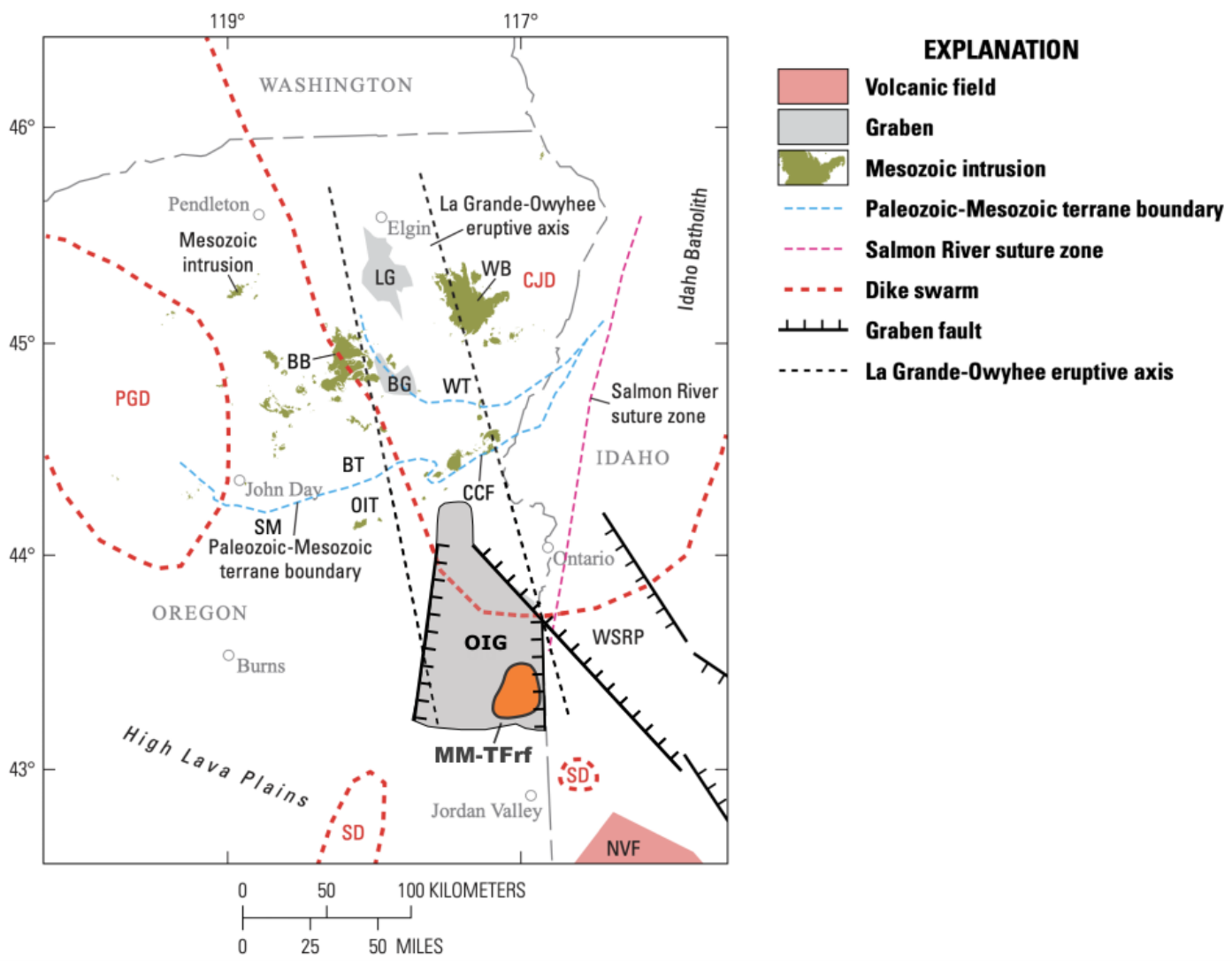

Figure 1. Sketch map showing major Paleozoic-Mesozoic age terrane boundaries in eastern Oregon and western Idaho. Major Mesozoic, Late Jurassic to Early Cretaceous age, intrusions in northeast Oregon are displayed in green. The Mahogany Mountain-Three Fingers rhyolite field (MM-TFrf) is shown in the orange polygon within the OIG grey shaded area. Regional features depicted are denoted by the following abbreviations: BB, Bald Mountain Batholith; BG, Baker Graben; BT, Baker terrane; CCF, Connor Creek Fault; CJD, Chief Joseph Dike Swarm; LG, La Grande graben; NVF, northern Nevada volcanic field; OIG, Oregon-Idaho graben; OIT, Olds Ferry-Izee terrane; PGD, Picture Gorge dike swarm; SD, Steens Mountain dike swarm; SM, Strawberry Mountain; WB, Wallowa Batholith; WSRP, Western Snake River Plain; WT, Wallowa terrane. Modified from Ferns et al., 2017.

The Mahogany Mountain—-Three Fingers rhyolite field (MM-TFrf) lies within the Olds Ferry-Izee terrain (Fig. 1), which is composed of a lower sequence of Permian to Late Triassic volcanic and volcaniclastic rocks, and an upper sequence of Late Triassic to Early Jurassic sedimentary rocks (Ferns et al., 2017). The sedimentary sequence consists of conglomerates with clasts of weathered volcanic Huntington formation, evaporite gypsum deposits and it fines upward into deep water turbidite facies consisting of 
argillites and fine-grained sandstones (Ferns et al., 2017). Additional reports observe metavolcanics consisting mostly of meta-andesite, and also plutonic rocks of the Cuddy and Iron Mountain areas (Tumpane, 2010). Spatially, it is in direct contact with the North American cratonic margin (Tumpane, 2010). The Olds Ferry terrane is thought to represent an accreted continental arc, with $\mathrm{Sr}, \mathrm{Nd}$, and $\mathrm{Pb}$ isotopic data from intrusive rocks of the terrane reflecting an isotopically enriched mantle source (Kurz et al., 2017). The pre-existing magmatic arc associated with the Olds-Ferry terrane may have played a role in the Cenozoic volcanism documented in my study area (Kurz et al., 2017).

\subsection{Columbia River Magmatic Province}

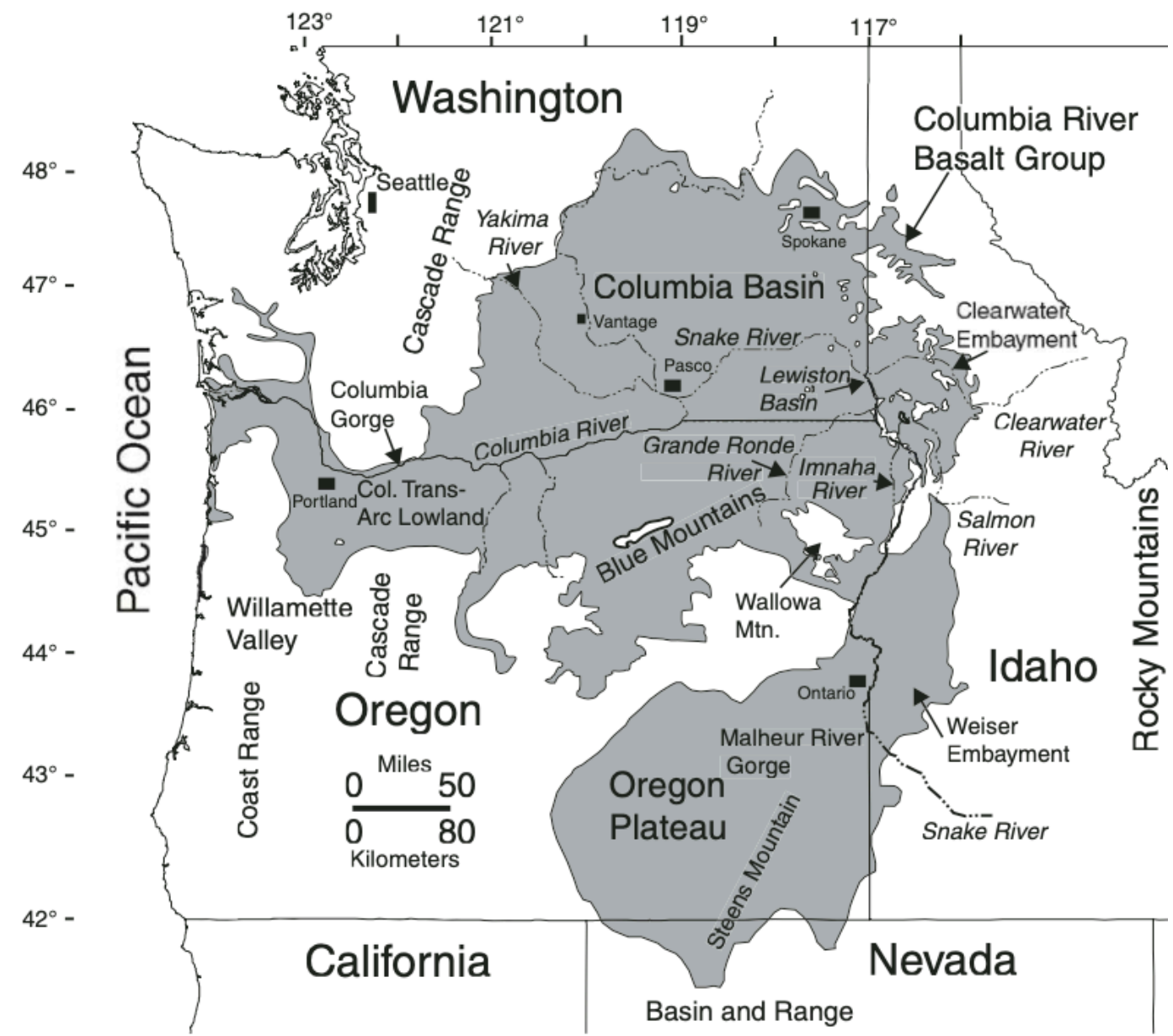

Figure 2. Map showing the areal extent of the Columbia River flood basalt province, in shaded area. Figure from Reidel et al. (2013). 
The middle Miocene Columbia River magmatic province is the youngest large igneous province on Earth, with lavas covering over 210,000 $\mathrm{km}^{2}$ of the Pacific Northwest (Fig. 2) (Reidel et al., 2013). The main phase of the Columbia River magmatic province, consisting of the Picture Gorge, Steens, Imnaha, and Grande Ronde Basalts, erupted over a period of 17.23 to $15.9 \mathrm{Ma}$ (Reidel et al., 2013; Cahoon et al., 2020). Three major dike swarms, the Chief Joseph, Monument and Steens dike swarms are thought to be the main venting sites for the CRBG (Fig. 3) (Camp \& Ross, 2004). Main phase Columbia River basalts volcanism began with fissure eruptions of the Picture Gorge Basalt in central Oregon via the Monument dike swarm, and contemporaneously, the Steens Basalt in southern Oregon via the Steens dike swarm, circa 17 Ma. As eruptions of the Steens Basalt waned, subsequent eruptions of the Imnaha Basalt via the Chief Joseph dike swarm followed, moving progressively northward from the Ontario, Oregon area to southeast Washington, west of and parallel to the Paleozoic craton boundary. Main phase Columbia River basalt volcanism ultimately ends with fissure eruptions of the Grande Ronde Basalt via the Chief Joseph dike swarm (Camp et al., 2003).

The Grande Ronde Basalt is composed of $\sim 100$ major flows, with a cumulative estimated eruptive volume of $150,400 \mathrm{~km}^{3}$ that composes over $71 \%$ of the total volume for the Columbia River Basalt Group and covers an estimated area of $169,600 \mathrm{~km}^{2}$ being emplaced over 0.42 m.y. (Fig. 3) (Camp et al., 2003; Barry et al., 2010; Reidel \& Tolan, 2013). Flows of the Grande Ronde are the largest known on Earth, featuring individual flow volumes ranging from $\sim 100 \mathrm{~km}^{3}$ to over $10,000 \mathrm{~km}^{3}$ (Reidel \& Tolan, 
2013). Grande Ronde Basalt flows are known to have erupted in the eastern part of the Columbia River flood basalt province via the Chief Joseph dike swarm (Reidel \& Tolan, 2013), extending as far north as Spokane Washington, with increasing thickness northward from Malheur Gorge in east central Oregon to the Columbia plateau (Hooper et al., 2007). Grande Ronde lavas are predominantly aphyric, tholeiitic basaltic andesites, and are texturally distinct in comparison to earlier coarse-grained Imnaha and Steens lavas.

Wolff et al., 2008 propose the Grande Ronde magmas are sourced from a principal CRBG magma reservoir system at least partly hosted in a transitional to cratonic crust, at depths of 15-30 km. Grande Ronde Basalt geochemistry has been modelled by Wolff et al., 2008, as being Imnaha magma modified through assimilation of cratonic crust. This reservoir system is proposed to consist of laterally extensive crustal magma chambers hosting Grande Ronde magmas located in the broad region among dike swarms and within other regional tectonic elements, such as the Oregon-Idaho graben and Western Snake River Plain. These reservoirs are thought to converge in eastern Oregon, but also extend eastward through the craton boundary allowing plume-derived basaltic magma to assimilate cratonic crust located east of the suture (Wolff et al., 2008).

More locally, a late-stage Grande Ronde basalt known as the Hunter Creek Basalt has been documented within the stratigraphy of the Malheur Gorge area, and in part of a well-preserved bimodal volcanic sequence just west of the Oregon-Idaho graben (Fig. 1) (Webb et al., 2018). Lava flows and pyroclastic vent deposits of the Hunter Creek basalt are geochemically similar to late-stage Grande Ronde Basalt, and are spatially and temporally associated with high-volume, widespread rhyolitic lavas within the Malheur 
Gorge (Webb et al., 2018). The timing of emplacement of the Hunter Creek Basalt along with the icelandite of Alder Creek has been stratigraphically constrained by the lower and upper Littlefield Rhyolite units placing eruption between 16.16 - 16.01 Ma (Webb et al., 2018). Geochemical modelling by Webb et al. (2018) has shown there is strong evidence for the icelandite of Alder Creek to be a mixing product of Hunter Creek Basalt and upper Littlefield Rhyolite magmas, providing evidence of the presence of a Grande Ronde magma storage site within the greater Malheur Gorge area and the co-existence of rhyolitic and Grande Ronde magma reservoirs.

\subsection{The Lake Owyhee Volcanic Field}

The impingement of the Yellowstone mantle plume is thought to be the cause of intrusion of widespread voluminous basalt magma into the crust, generating the midMiocene silicic volcanism documented at three major volcanic fields: the High Rock caldera complex, the McDermitt volcanic field, and the Lake Owyhee volcanic field (LOVF) (Coble \& Mahood, 2012). Our study focuses on the rhyolite volcanism observed at the Mahogany Mountain-Three Fingers rhyolite field, located in the Lake Owyhee Volcanic Field (Fig. 3), which is nearly contemporaneous with the end of the Grande Ronde Basalt flows of the CRBG.

The LOVF was originally defined by Rytuba et al. (1994) to consist of seven regionally extensive ignimbrites with five associated calderas, with several smaller volcanic centers consisting of coalescing rhyolite domes and minor basalt flows emplaced across $\sim 20,000 \mathrm{~km}^{2}$ of eastern Oregon, bordering Idaho. The source calderas for four of the seven ignimbrites were identified to consist of the tuff of Leslie Gulch forming the Mahogany Mountain caldera $(15.5 \pm 0.05 \mathrm{Ma})$, the tuff of Spring Creek from 
the Three Fingers caldera (ca. 15.3 Ma) in the east-central part of the LOVF, the Dinner Creek Tuff from the "Castle Peak" or Castle Rock caldera (ca. 15.3 Ma) in the northwest part of the LOVF, and the tuff of Birch Creek (estimated age of 15.0 Ma) postulated to be sourced from the "Saddle Butte" caldera (Rytuba et al., 1991). However, the "Saddle Butte" caldera is undefined in the literature, and more recent studies propose new interpretations to source magmas and calderas for the MM-TFrf (Ferns et al., 1997; Benson \& Mahood, 2016).

Recent studies of the area have yielded new ages for select rhyolites of the LOVF, more accurately refining the sequence of events for mid-Miocene silicic volcanism. New ages include the Dinner Creek Tuff unit $1(16.16 \pm 0.02 \mathrm{Ma})$, the Lower Littlefield rhyolite $(16.17 \pm 0.06 \mathrm{Ma}, 16.09 \pm 0.04 \mathrm{Ma})$, and the Upper Littlefield rhyolite $(16.05 \pm$ $0.05 \mathrm{Ma}, 15.98 \pm 0.06 \mathrm{Ma})$, in addition to rhyolites of the MM-TFrf which will be discussed in further detail below (Streck et al.,2015; Ferns et al., 2017; Webb et al., 2018). These new ${ }^{40} \mathrm{Ar} /{ }^{39} \mathrm{Ar}$ ages give higher precision estimates for rhyolite volcanism in the LOVF and shift initiation of silicic volcanism back to be more contemporaneous with late-stage Grande Ronde Basalts than previously thought. 


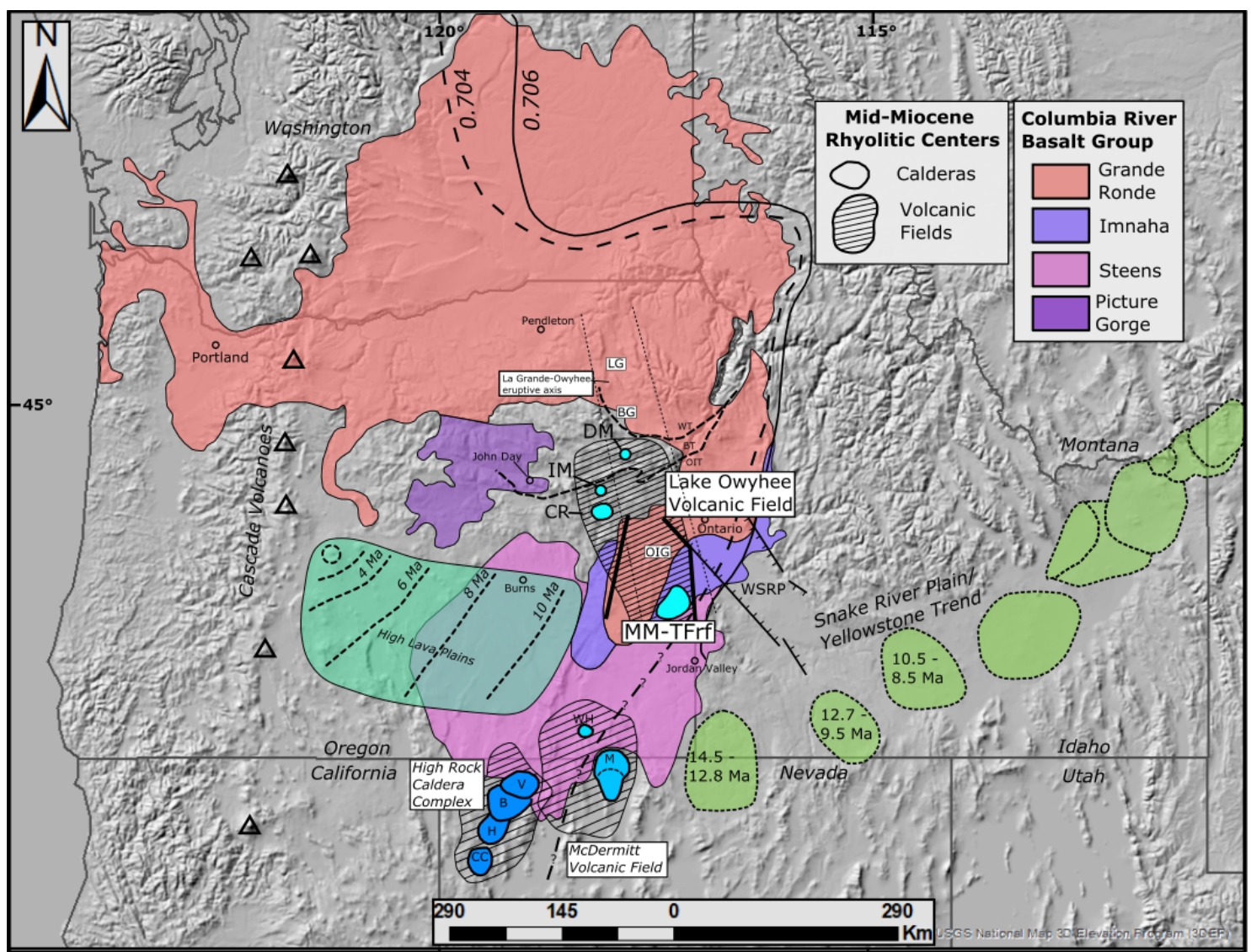

Figure 3. Regional map displaying the areal extents of the Columbia River basalts, as well as contemporaneous rhyolitic centers. The Oregon-Idaho graben is marked by the thick black lines. The Lake Owyhee volcanic field (LOVF) is delineated by the cross-hatched polygon. The Mahogany Mountain-Three Fingers rhyolite field (MM-TFrf) is shown in the southeast of the volcanic field. This figure was modified from Benson et al., (2016).

\subsection{The Oregon-Idaho Graben}

The Mahogany Mountain-Three Fingers rhyolite field (MM-TFrf) is located within the Oregon-Idaho graben (OIG), which is a 50-km-wide north-south trending synvolcanic graben in southeastern Oregon and southwestern Idaho (Figure 1) (Cummings et al., 2000). Mid-Miocene tholeiitic basalts define the graben margins with the basalt of Malheur Gorge on the western flank and the basalt of Bishop's Ranch on the eastern flank (Ferns, 1997; Cummings et al., 2000). The OIG is located at the juncture of several major geologic provinces of the northwestern United States, being the northern extent of 
the Basin and Range, the southern extent of the Columbia Plateau, the western edge of the Snake River Plain, and the eastern extent of the High Lava Plains. The OIG lies along the Mesozoic ${ }^{87} \mathrm{Sr} /{ }^{86} \mathrm{Sr} 0.704$ line and just west of the ${ }^{87} \mathrm{Sr} /{ }^{86} \mathrm{Sr} 0.706$ line (Figure 2), which isotopically represents the boundary between the accreted Olds Ferry-Izee and Baker oceanic terranes and the North American cratonic margin (Leeman et al.,1992).

The OIG evolved as part of a north- to northwest trending mid-Miocene volcanic rift system known as the La Grande-Owyhee eruptive axis, which includes the northern Nevada Rift, La-Grande, and Baker grabens, and the Columbia River basalt dike swarms (Ferns \& McClaughry, 2013). Initial subsidence of the graben (15.5-15.3 Ma) follows the largest eruptions of the Columbia River magmatic province and coincides with eruptions of rhyolite lavas and ash-flow tuffs from vents along the margins and interior of the graben, such as the MM-TFrf (Cummings et al., 2000; Ferns \& McClaughry, 2013).

Several north-trending intra-graben fault zones are observed and may serve as magmatic and hydrothermal conduits, including the Wall Rock Ridge fault zone, Dry Creek fault zone, and Devils Gate fault zone (Ferns, 1997; Cummings et al., 2000). Each fault zone typically consists of an approximately $2-3 \mathrm{~km}$-wide zone of closely spaced, short strike length, steeply dipping normal faults (Cummings et al., 2000). The fault zones are thought to exert controls on rhyolite volcanism, as well as the distribution of sedimentary facies during graben evolution (Cummings et al., 2000). 


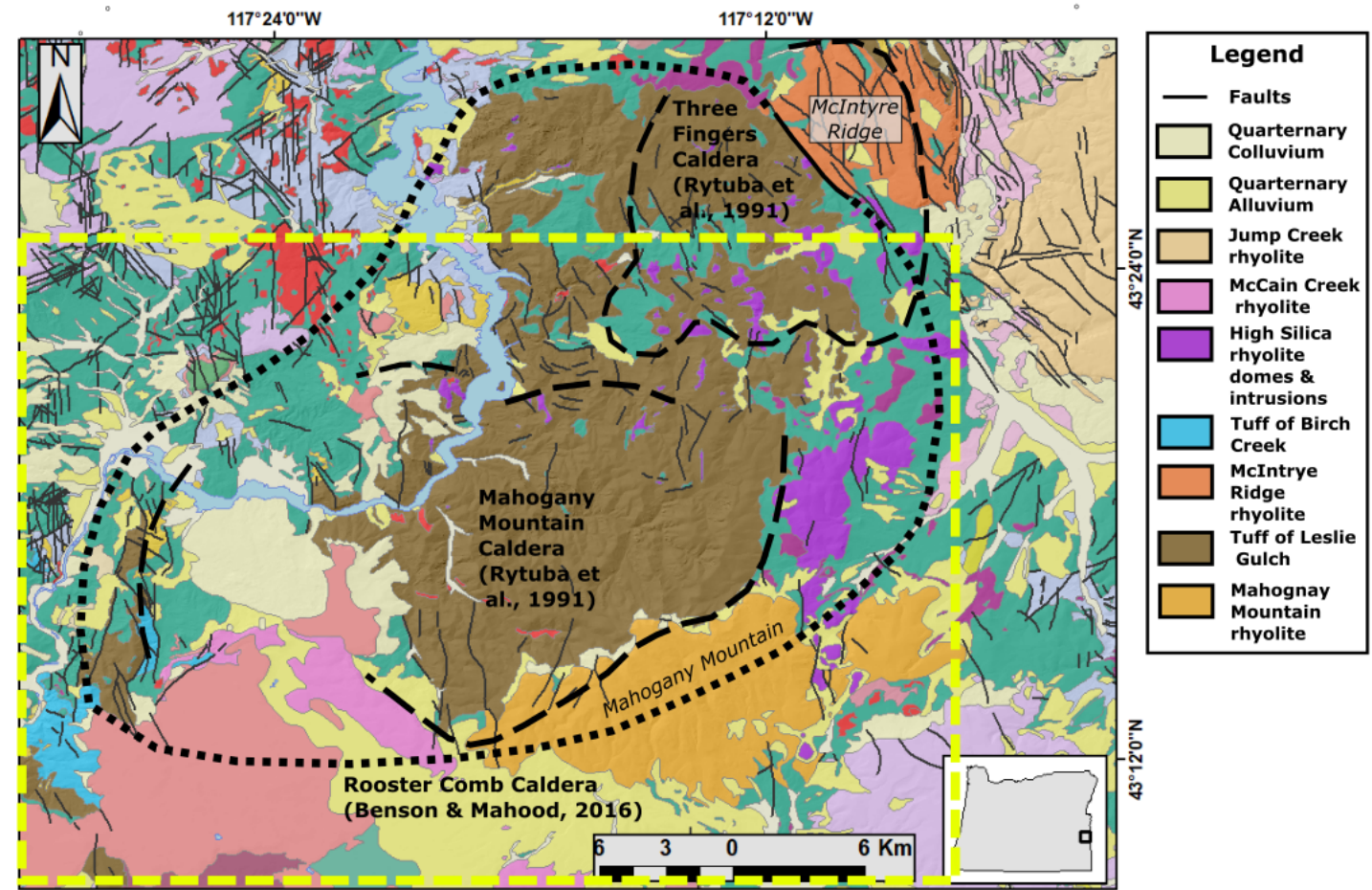

Figure 4. Regional map of the Mahogany Mountain-Three Fingers rhyolite field showing the approximate caldera margins of the Mahogany Mountain and Three Fingers calderas from Rytuba et al., (1991), and the Rooster Comb caldera from Benson \& Mahood (2016). Modified from Ferns (1993) 1:100,000 scale geology map. Yellow-dashed box indicates the extent of this study.

\subsection{Previous Studies of the Mahogany Mountain-Three Fingers Rhyolite Field}

The Mahogany Mountain caldera (MMC) as originally defined by Rytuba et al. (1985), is located mostly along the eastern margin of the Lake Owyhee Reservoir in eastern Oregon, just north of Mahogany Mountain and approximately $15 \mathrm{~km}$ west of the Idaho state line (Fig. 4). The MMC is thought to have formed during the eruption of tuff of Leslie Gulch (Vander Meulen, 1989). A second caldera was proposed by Rytuba et al. (1991) to be located just north of the MMC and it was named the Three Fingers caldera (Fig. 4). The Three Fingers caldera is thought to have formed upon the eruption of the tuff of Spring Creek (Vander Meulen, 1989; Rytuba et al. 1991). The eruptions of the tuff 
of Leslie Gulch and tuff of Spring Creek, both represent expressions of early silicic volcanism for the LOVF (Vander Meulen, 1989; Rytuba et al.,1991).

The MMC spans approximately 15 - by $20-\mathrm{km}$, defined by a $25 \mathrm{mGal}$ gravity low (Vander Meulen, 1989). The southern margin is composed of the high-silica rhyolite lavas and dome complex named the Mahogany Mountain rhyolite (Rytuba et al., 1991). The northern and western margins are poorly defined topographically, with the eastern margin apparently truncated by the Devils Gate fault zone, as defined by spatial relationship of an arcuate mass of thick ash-flow and air-fall deposits with a prominent, arcuate gravity low (Rytuba et al. 1991; Ferns, 1997).

Vander Meulen (1989) interprets the MMC to have evolved in three stages: 1) volcanism initiates with eruption of pre-caldera lavas including the Mahogany Mountain rhyolite, 2) voluminous eruption of ash-flow and air-fall tuff coincident with caldera collapse generating the tuff of Leslie Gulch, and 3) eruptions of rhyolite lavas and tuffs via post-caldera ring-fractures resulting in rhyolite dikes, domes, lavas, plugs and a variety of tuffs. Post-caldera tuffs include the tuff of Spring Creek and the tuff of Birch Creek (Vander Meulen, 1989). Following post-caldera eruptions, a north-trending graben formed in the central resurgent dome producing a caldera moat. The MMC moat was later filled by the tuff of Spring Creek, erupting from the Three Fingers caldera positioned $3 \mathrm{~km}$ to the northeast (Vander Meulen, 1989).

Vander Meulen and others (1987b) report K-Ar ages for the tuff of Leslie Gulch $(15.5 \pm 0.5 \mathrm{Ma})$ marking the timing of caldera formation, an age of $14.0 \pm 0.4 \mathrm{Ma}$ for a north-west striking rhyolite dike within the Mahogany Mountain caldera, and an age of $12.8 \pm 0.3 \mathrm{Ma}$ for the Bannock Ridge rhyolite dome and flow complex. Silicic volcanism 
for the MMC was concluded with two north-trending rhyolite dike systems intruding the caldera interior (14.0 Ma), and several rhyolite domes and plugs intruding the north and eastern margins of the caldera, such as the Bannock Ridge rhyolite (Vander Meulen, 1989). Emplacement of many of the rhyolite lavas mapped and observed within the MM-TFrf are positioned approximately within or near three fault zones within the OIG. These include, from east to west, the Devil's Gate fault zone, the Dry Creek Butte fault zone, and the Wall Rock Ridge fault zone (Cummings et al., 2000).

Initial studies of the MM-TFrf advocated for a two-caldera model with the Mahogany Mountain and Three Fingers calderas, occurring closely in time but with distinct and separate silicic centers (Vander Meulen, 1989; Rytuba et al., 1991). However, a recent study conducted by Marcy (2013), identified much of the "tuff of Spring Creek" mapped within the Three Fingers caldera as dense devitrified intra-caldera rhyolite lavas, subsequently named the 'Three Fingers rhyolite'. This suggests much of the rhyolite thought to characterize the presence of the Three Fingers caldera, could also be one large caldera, effectively reducing the estimated volume of the tuff of Spring Creek. Additionally, Marcy reported an age of $15.74 \pm 0.09$ Ma for the intra-caldera Three Fingers rhyolites, reflecting emplacement atop intra-caldera sediments.

A more recent study conducted by Benson \& Mahood (2016), provided new ${ }^{40} \mathrm{Ar} /{ }^{39} \mathrm{Ar}$ ages and new interpretations for volcanic units of the MM-TFrf including the Birch Creek low-silica rhyolite (16.87 $\pm 1.1 \mathrm{Ma})$, the McIntyre Ridge rhyolite (16.01 \pm $0.27 \mathrm{Ma})$, the tuff of Leslie Gulch $(15.94 \pm 0.05 \mathrm{Ma})$, the tuff of Spring Creek $(15.93 \pm$ $0.04 \mathrm{Ma})$, the Three Fingers rhyolite $(15.82 \pm 0.06 \mathrm{Ma})$, the Mahogany Mountain rhyolite $(15.73 \pm 0.05 \mathrm{Ma})$, and the Smith Butte rhyolite lava dome $(15.71 \pm 0.05 \mathrm{Ma})$. The 
authors proposed an alternative model for the MM-TFrf, suggesting the tuff of Spring Creek is an altered product of the tuff of Leslie Gulch and as a result the Mahogany Mountain and Three Fingers calderas are actually one large caldera. In contrast to previous studies of the area, the authors interpret the Mahogany Mountain rhyolite as an expression of post-caldera volcanism that reflects a recharge event within the chamber, which is supported by their geochemical, mineralogical, and geochronological data. Ages reported here are relative to the Fish Canyon tuff sanidine 28.201 standard. 


\section{CHAPTER 3: METHODS}

\subsection{Geologic Mapping \& Sampling}

Fieldwork was completed over a period of four weeks in the summer of 2019 and consisted of geologic mapping and sampling of eruptive units associated with the Mahogany Mountain caldera. Geologic mapping was conducted at a 1:24,000 scale to investigate the distribution and stratigraphic relationships of the Mahogany Mountain rhyolite as well as neighboring rhyolite domes and lavas. The study area was accessed through use of dirt roads, ATV trails, and hiking.

Sample locations were recorded with an iPhone 8 Plus using the Avenza Maps application and the phone's internal GPS. Samples were collected and documented for lithologic characteristics and location in local stratigraphy or position in the lava dome. Lava dome and flow samples were collected from outcrops or from float pavements when no outcrops were available. Glassy lithologies were preferentially sampled as to avoid potential silicification of devitrified samples. However, devitrified material was sampled when glassy material was lacking. Attention was given to avoid sampling material which had undergone alteration, since the region was susceptible to hydrothermal processes during periods of volcanic subsidence (Cummings et al., 2000). Samples were prepared for future petrographic, geochemical, isotopic, and geochronologic analyses at Portland State University. A geologic map with sample locations is available as Appendix G. 


\section{2 ${ }^{40} \mathrm{Ar} /{ }^{39} \mathrm{Ar}$ Dating}

${ }^{40} \mathrm{Ar} /{ }^{39} \mathrm{Ar}$ ages for the rhyolites of this study were acquired from feldspar phenocrysts separated from fresh sample material and the analysis was performed at the Oregon State University (OSU) ${ }^{40} \mathrm{Ar} /{ }^{39} \mathrm{Ar}$ Geochronology Laboratory. Detailed ${ }^{40} \mathrm{Ar} /{ }^{39} \mathrm{Ar}$ incremental heating methods and age plateaus can be found in Appendix A.

\subsection{Thin Section Petrography}

For petrographic analysis, a set of 12 rhyolite samples were chosen from units present at the Mahogany Mountain caldera. Sample billets were prepared using a rock saw. Sample billets were sent to Spectrum Petrographics in Vancouver, WA, for polished thin section preparation. All samples were polished down to a thickness $30 \mu \mathrm{m}$. Each sample was analyzed using a petrographic in plane polarized and cross polarized light. Mineral assemblages, phenocryst proportions and texture, and groundmass texture were documented. Scanning electron microscope (SEM) analysis was undertaken to obtain mineral data. A complete list of photos of thin sections can be found in Appendix B.

\subsection{Bulk Geochemical Analysis}

A total of 30 samples were analyzed for major and trace element concentrations to better characterize the geochemical variation and composition for each unit. Samples were selected based on preservation, location, and perceived unit, to accurately document the study area. Sample analyses were conducted at the GeoAnalytical Lab at Washington State University, using X-Ray Fluorescence (XRF) and Inductively Coupled Plasma Mass Spectrometry (ICP-MS) following the methods of Johnson et al. (1999). Samples were crushed in house at Portland State University and transported to Washington State University for glass bead and powder preparation and analysis. The GeoAnalytical Lab at 
WSU states the analytical precision for ICP-MS analysis is 5\% (RSD) for Rare Earth Elements and $10 \%(\mathrm{RSD})$ for trace elements. The geochemical data obtained for samples collected during this study are found in Appendix C \& D. All sample preparation was conducted by me at the GeoAnalytical Lab at Washington State University.

\section{$3.5 \delta^{18} O$ Isotope Analysis}

Oxygen isotope analyses were performed on mineral separates of quartz, plagioclase, alkali feldspar, separated from crushed sample material. Three oxygen isotope analysis was performed at University of Oregon. Oxygen was separated from minerals using laser fluorination and a $35 \mathrm{~W}$ Newwave $\mathrm{CO}_{2} \mathrm{IR}$ laser in $\mathrm{O}_{2}$ mode. A Finnigan MAT 253, large radius $10 \mathrm{kv}$ gas source mass spectrometer was used to perform the final oxygen gas analysis. This method yielded values with an error of better than $\pm 0.1 \%$, 1 standard deviation. Magma $\delta^{18} \mathrm{O}$ values were calculated using results from the bulk crystal analyses (Bindeman and Valley, 2002, 2003; Bindeman et al., 2004). Detailed oxygen isotopic methods and further calculations can be found in Appendix E.

\subsection{Scanning Electron Microscopy}

Major element concentrations for feldspar, clinopyroxene, and Fe-Ti oxide phenocrysts, were collected using the Zeiss Sigma VP Scanning Electron Microscope with Energy Dispersive X-Ray Spectrometry (SEM-EDX), at Portland State University. Analysis was conducted on thin sections and epoxy plugs containing hand-picked crystals. Additional microanalytical work consisted of acquiring qualitative imagery of phenocryst phases present in each sample using the back-scatter electron detector (BSE). Detailed SEM methods and data are found in Appendix F. 


\section{CHAPTER 4: RESULTS}

\subsection{New ages for rhyolites of the Mahogany Mountain-Three Fingers Rhyolite}

\section{Field}

${ }^{40} \mathrm{Ar} /{ }^{39} \mathrm{Ar}$ ages results of the five dated samples will be presented first to give a temporal context to units of this study. Samples selected include one sample of the 'rhyolite SE of Round Mt.', three samples of the Mahogany Mountain rhyolite, and one sample of the McCain Creek rhyolite. The resulting age determinations are relative to Fish Canyon Tuff (FC-1) sanidine monitors (28.201 Ma). Full results are listed in Appendix A. 


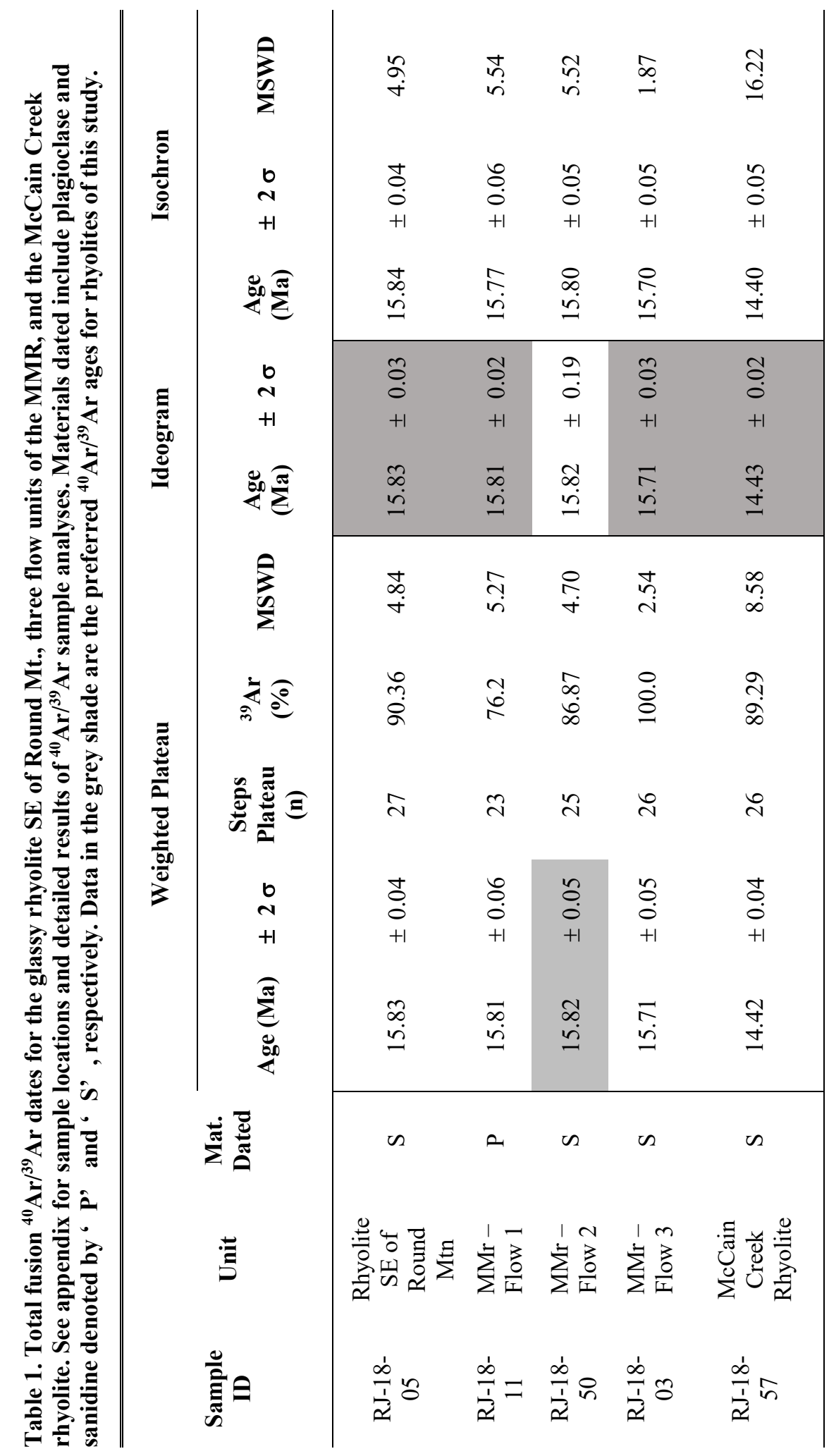




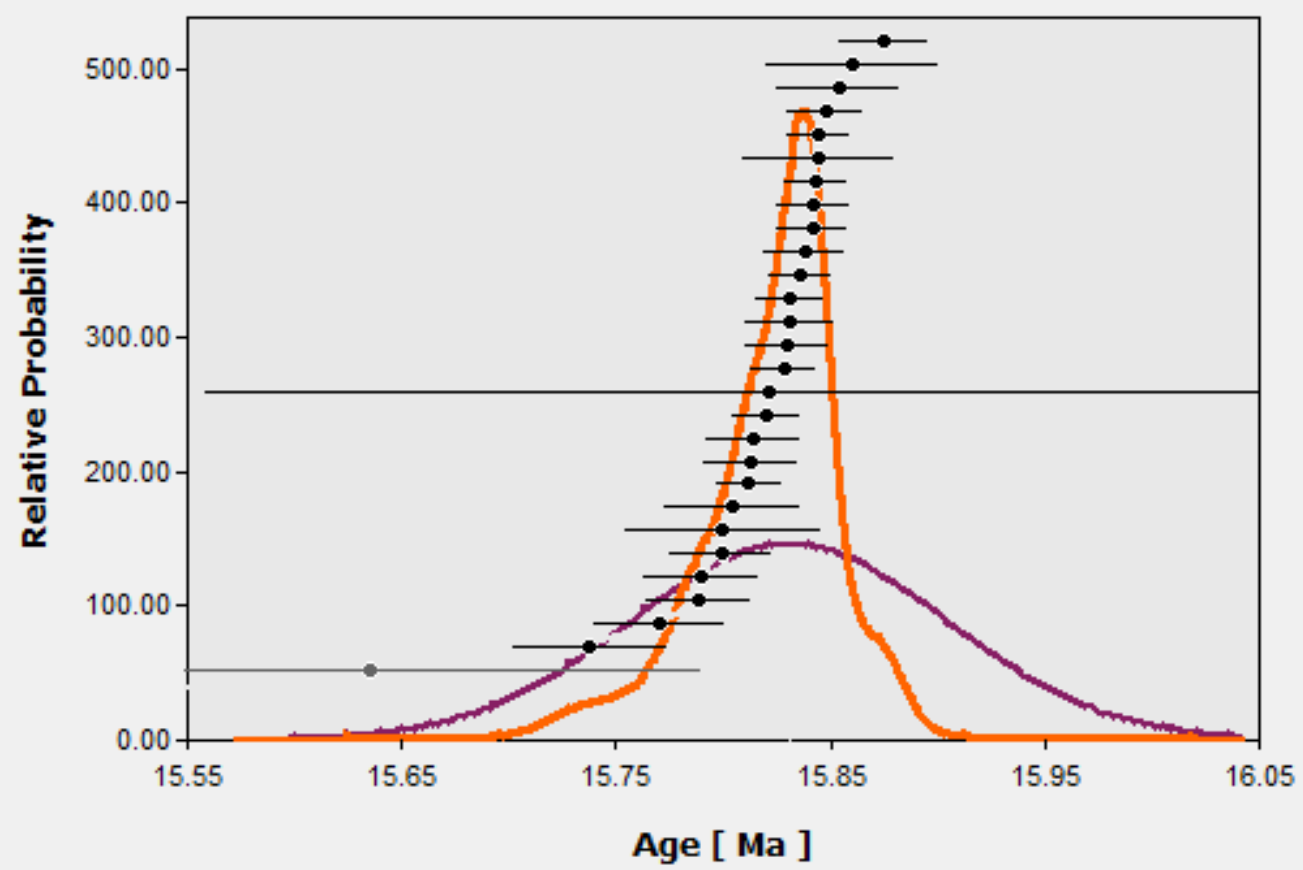

Figure 5. Ideogram of ${ }^{40} \mathrm{Ar} /{ }^{39} \mathrm{Ar}$ dating results for the 'Rhyolite SE of Round Mtn' yielding an age of $15.83 \pm 0.03 \mathrm{Ma}$, sample number: RJ-18-05. The red line signifies age estimates for individual crystals of this sample. The purple line signifies the probability density curve based on age estimates for crystals of the sample.

Obtained eruption ages for rhyolite lavas of this study all indicate post-caldera emplacement, which is supported by stratigraphic observations in the field. Field observations often consist of rhyolite lavas and domes overlying fine-grained tuffaceous sediments in intra-caldera and extra-caldera settings, suggesting their timing of emplacement occurred during either syn- or post-caldera stages of development. The 'Rhyolite SE of Round Mt. sample (RJ-18-05) yielded an ideogram age of $15.83 \pm 0.03$ Ma, putting the estimated timing of eruption close behind the last eruption of the tuff of Leslie Gulch at 15.86 $\pm 0.05 \mathrm{Ma}$ (Streck \& McIntosh, in prep.). 


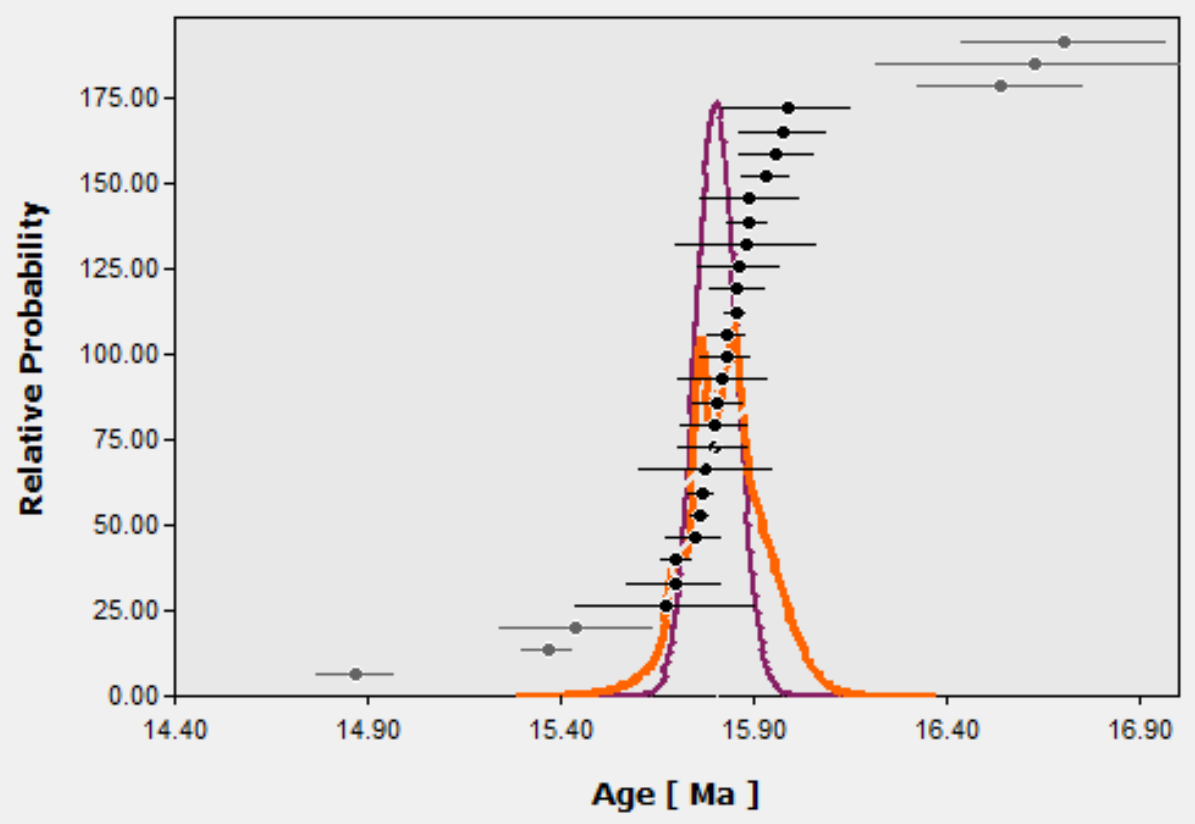

Figure 6. Ideogram of ${ }^{40} \mathrm{Ar} /{ }^{39} \mathrm{Ar}$ dating results for the Mahogany Mountain rhyolite, flow unit 1, yielding an age of $15.81 \pm 0.02 \mathrm{Ma}$. Sample number: RJ-18-11. The red line signifies age estimates for individual crystals of this sample. The purple line signifies the probability density curve based on age estimates for crystals of the sample.

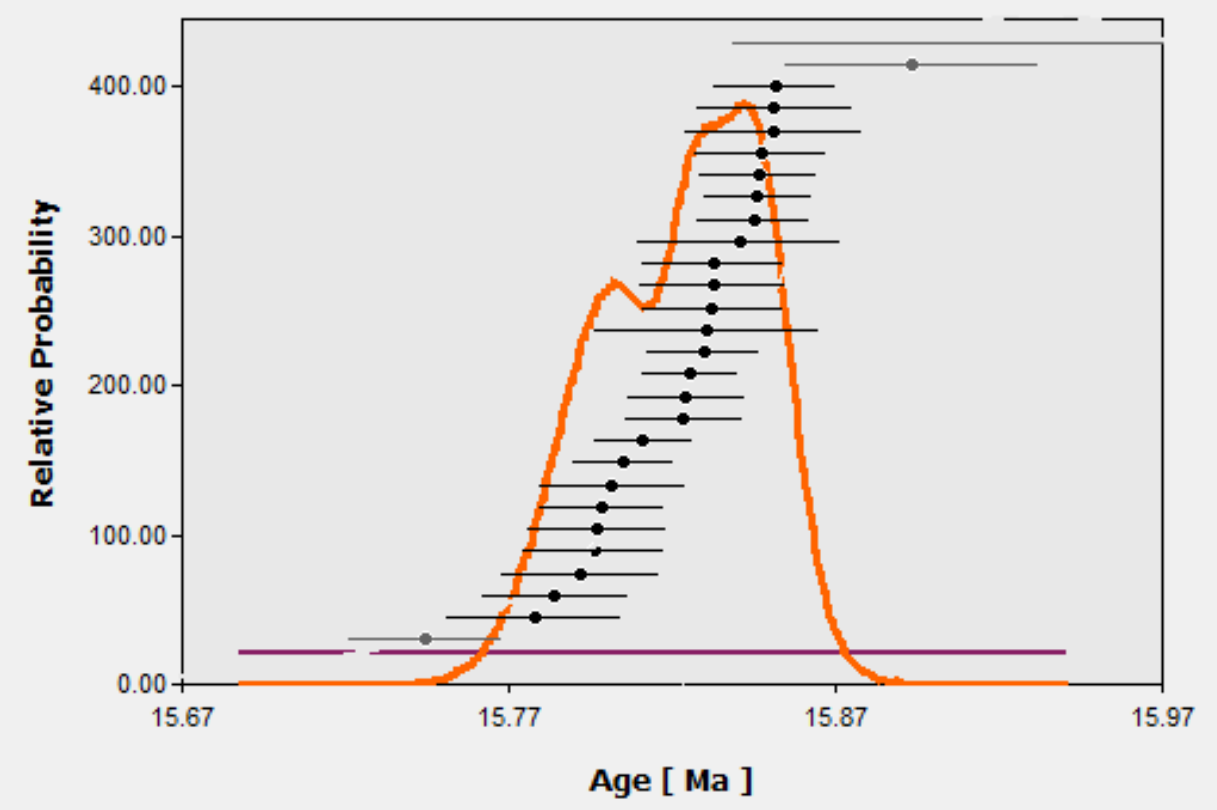

Figure 7. Ideogram of ${ }^{40} \mathrm{Ar} /{ }^{39} \mathrm{Ar}$ dating results for the Mahogany Mountain rhyolite, flow unit 2 , yielding an age of $15.82 \pm 0.05 \mathrm{Ma}$. Sample number: RJ-18-50. The red line signifies age estimates for individual crystals of this sample. The purple line signifies the probability density curve based on age estimates for crystals of the sample. 


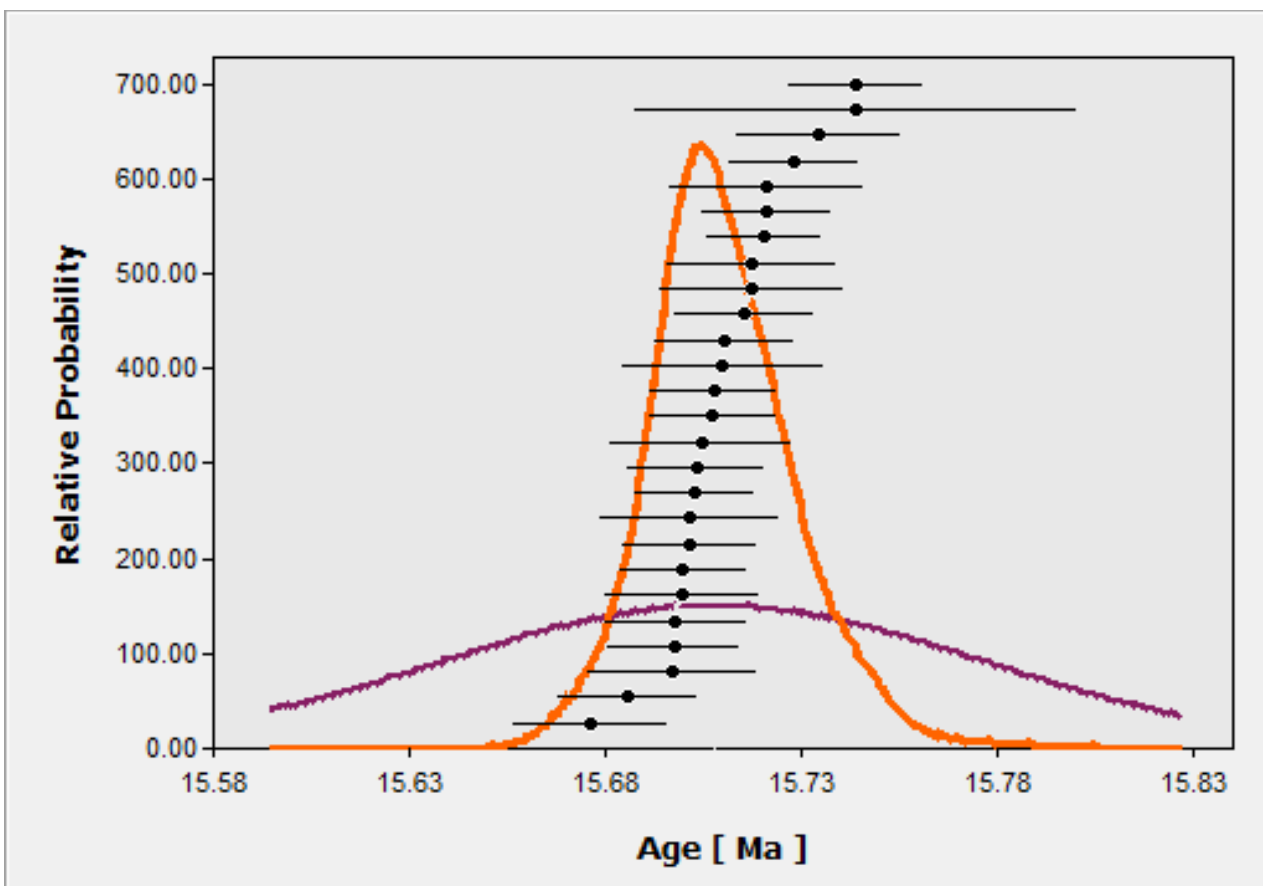

Figure 8. Ideogram of ${ }^{40} \mathrm{Ar} /{ }^{39} \mathrm{Ar}$ dating results for the Mahogany Mountain rhyolite, flow unit 3, yielding an age of yielding an age of $15.71 \pm 0.03 \mathrm{Ma}$. Sample number: RJ-18-03. The red line signifies age estimates for individual crystals of this sample. The purple line signifies the probability density curve based on age estimates for crystals of the sample.

Individual flow units of the Mahogany Mountain rhyolite were dated revealing a three-stage emplacement sequence initiating at $15.82 \pm 0.05 \mathrm{Ma}$, followed by a geochemically similar batch of Mahogany Mountain rhyolite lava erupting at $15.81 \pm$ $0.02 \mathrm{Ma}$, with the final flow unit being emplaced at $15.71 \pm 0.03 \mathrm{Ma}$. The ages for flow unit 1 and 2 are within error of one another, and I base their relative emplacement on compositional data and the interpretation therefore, this will be discussed in the next section. 


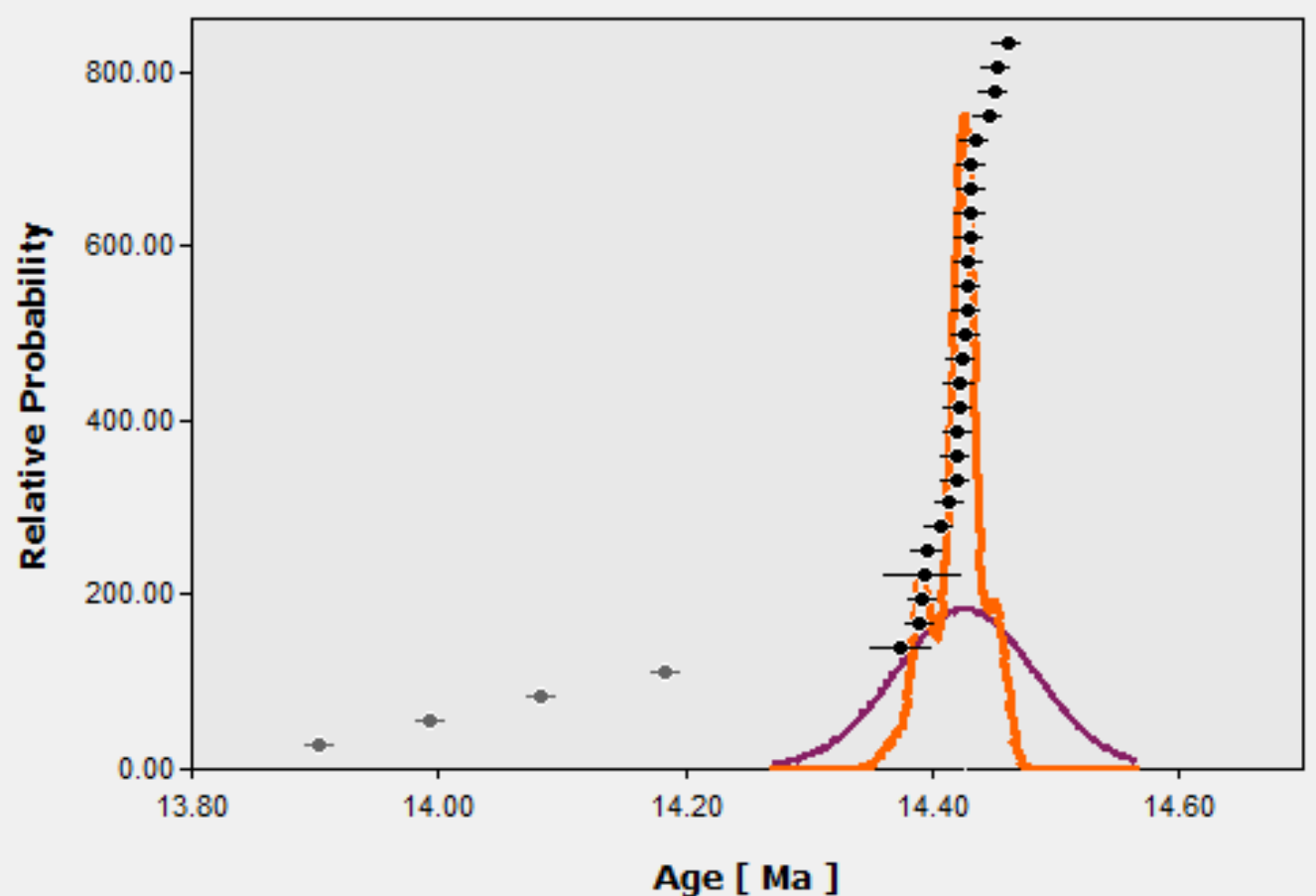

Figure 9. Ideogram of ${ }^{40} \mathrm{Ar} /{ }^{39} \mathrm{Ar}$ dating results of the McCain Creek rhyolite yielding an age of $14.43 \pm 0.02$ Ma. Sample number: RJ-18-57. The red line signifies age estimates for individual crystals of this sample. The purple line signifies the probability density curve based on age estimates for crystals of the sample.

A sample of the McCain Creek rhyolite lava (sample RJ-18-57) yielded an ideogram age of $14.43 \pm 0.02 \mathrm{Ma}$ (Fig. 9). This date indicates the McCain Creek rhyolite was emplaced subsequent to main-phase volcanism for the Mahogany Mountain caldera (Fig. 55). 


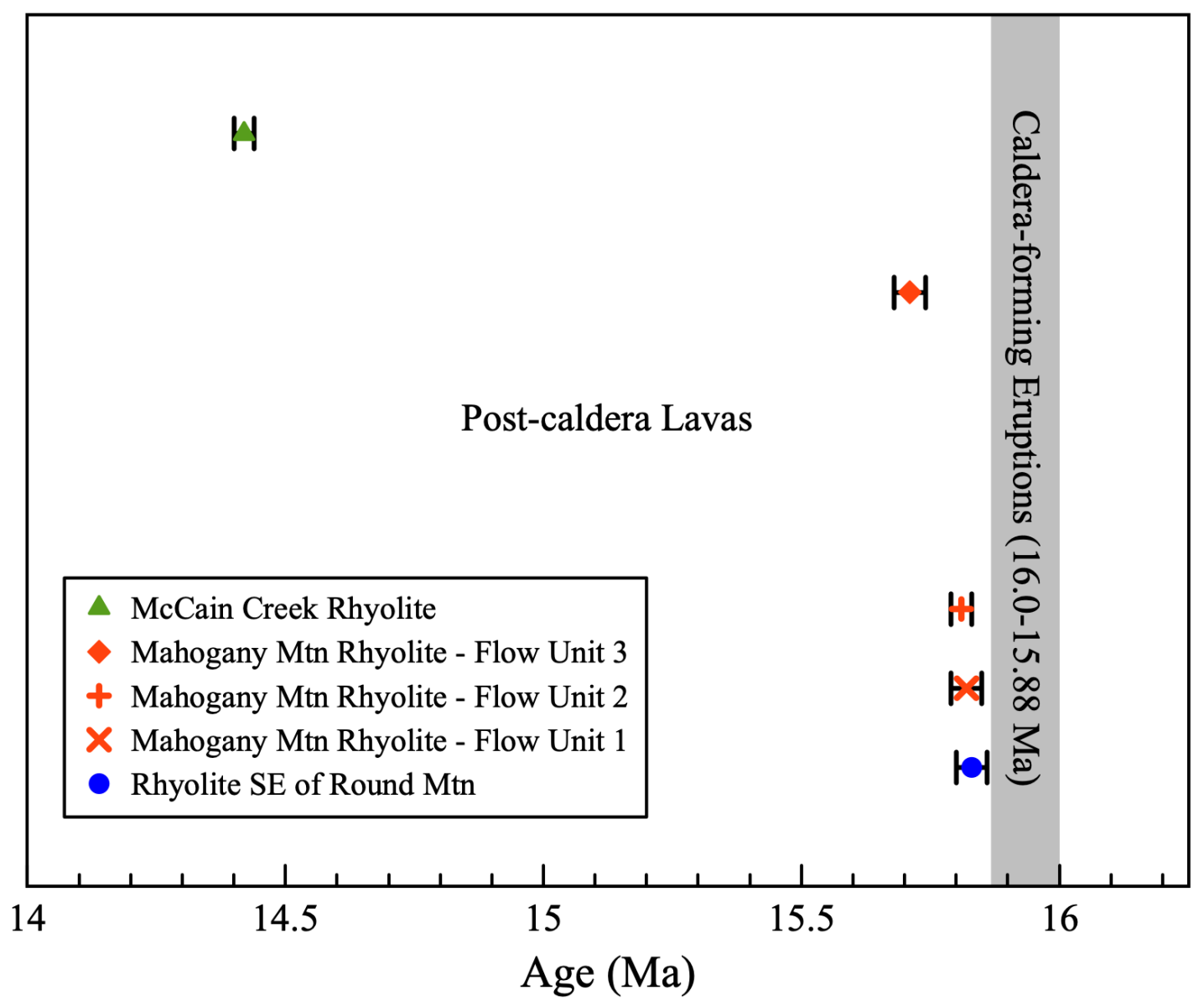

Figure 10. Age plot for ${ }^{40} \mathrm{Ar} /{ }^{39} \mathrm{Ar}$ dating results for rhyolite lavas of this study. Shaded area represents the duration of tuff of Leslie Gulch units (Streck\& McIntosh, in prep.). 


\subsection{Eruptive Stratigraphy of the Mahogany Mountain-Three Fingers Rhyolite}

\section{Field - Overview}

Geologic units of the Mahogany Mountain — Three Fingers rhyolite field (MMTFrf) can be grouped into four major periods of development. The first period is the precaldera stage and is represented by a glassy rhyolite lava identified stratigraphically beneath the tuff of Leslie Gulch and located within Leslie Gulch (Streck \& McIntosh, pers. comm.). The highly explosive caldera-forming stage that followed is represented by the composite tuff of Leslie Gulch. The post-caldera volcanism stage is expressed with rhyolite lavas forming dikes, plugs, domes and flows, cross cutting and capping the caldera-forming tuffs and tuffaceous sediments within and outside of the caldera and smaller pyroclastic units. The final stage of development is characterized by postvolcanism sedimentation within the graben, often obscuring contacts.

A series of rhyolite units can be distinguished among those of the post-caldera stage, consisting of the 'rhyolite SE of Round Mountain', the Bannock Ridge rhyolite, the Mahogany Mountain rhyolite, and Smith Butte rhyolite lavas of this study, in addition to the Devils Gate rhyolite (aka Old McIntyre rhyolite), the McIntyre rhyolite (aka Young McIntyre rhyolite), and the intra-caldera Three Fingers rhyolite (Marcy, 2013; Hess, 2014; Ferns et al., 2017; Black, 2021). Eruptions of these post-caldera lavas are intermittently punctuated with explosive eruptions of pyroclastic material including the tuff of Succor Creek (formerly labeled tuff of Spring Creek along Succor Creek, cf. Ferns et al., 2017) and fallout and ash-flow tuffs that crop out in the northwestern portion of the MM-TFrf belonging to the Honeycomb eruptive unit (Vander Meulen, 1989), as well as intercalated tuffs of the Three Fingers area. Post-rhyolite sedimentation consists of 
tuffaceous sediments of the Succor Creek formation, derived from loosely consolidated material within the basin and the existing volcanic rocks of the Mahogany MountainThree Fingers rhyolite field, as well as arkosic sandstones derived from eroded older rocks to the east of the study area (Ferns et al., 2017), and Quaternary-age alluvium, colluvium, and landslides.

Lava flows and domes of the Birch Creek rhyolite and McCain Creek rhyolite are located on the southwestern and southern flanks of the caldera, respectively (Fig. 11). The Birch Creek rhyolite and McCain Creek rhyolite units are found to have geochemical and mineralogical signatures that set them apart from other rhyolite units of the MMTFrf. Additionally, they have yielded significantly younger eruption ages indicating these units represent rhyolite volcanism subsequent to main-phase volcanism of the MM-TFrf. Rhyolite units will be discussed in greater detail in following sections. 

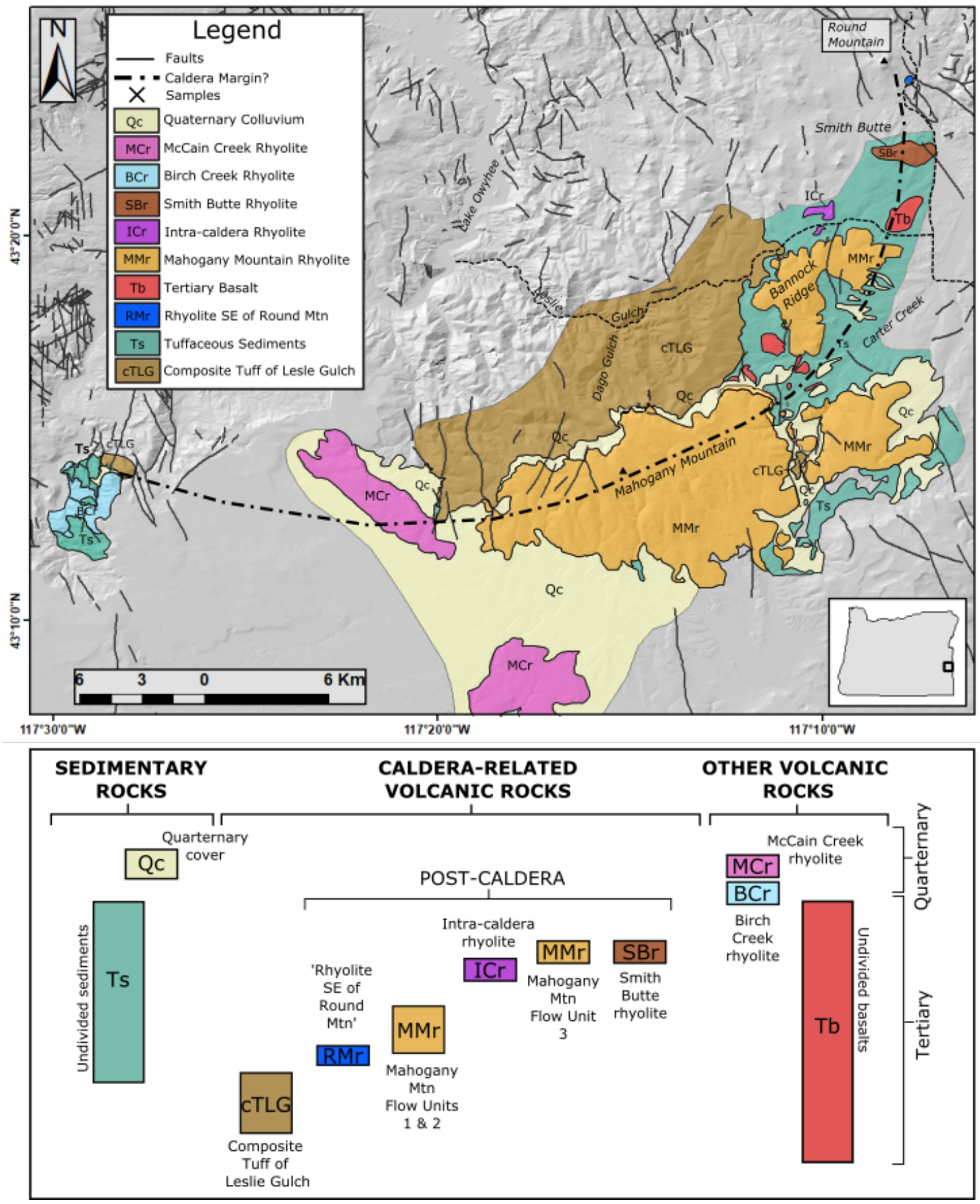

Figure 11. Geologic map generated by mapping extents of rhyolite units within the study area and created using Arcmap 10.6. Faults are based on from Ferns et al. (1993). The dashed line marks the Succor Creek Road and Leslie Gulch Road. Caldera margin is drawn based on the presence of intra-caldera tuff of Leslie Gulch and post-caldera rhyolite units, as well as the topographic high of Mahogany Mtn. Map projection and datum are North American Datum 1983. 

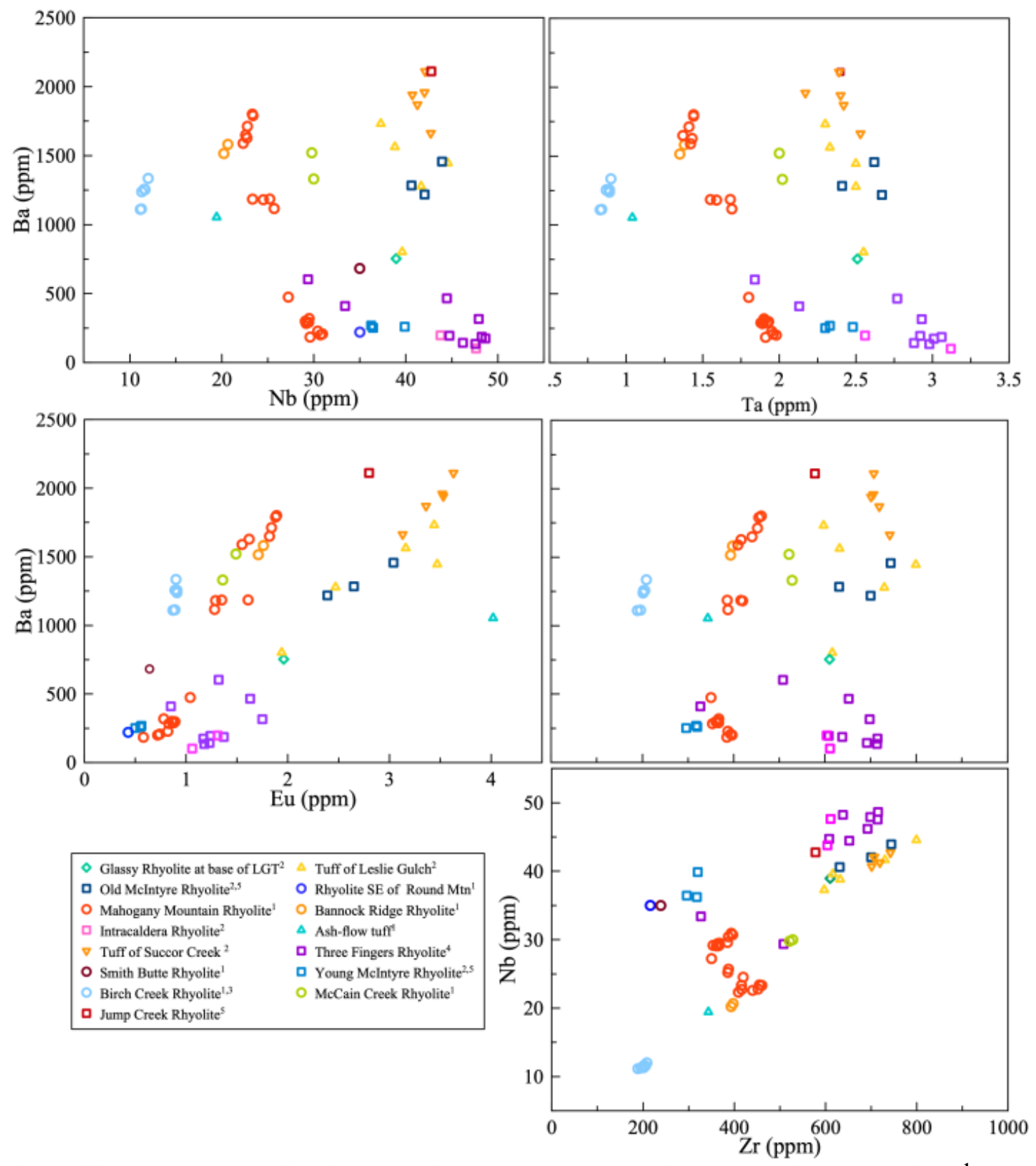

Figure 12. Trace element bivariate plots for Mahogany Mountain-Three Fingers rhyolites. ${ }^{1}$ : samples of this study. ${ }^{2}$ : samples of Streck \& others. ${ }^{3}$ : samples of Swenton, unpub. ${ }^{4}$ : samples of Marcy, 2013. ${ }^{5}$ : samples of Hess, 2014. 


\subsubsection{The Composite Tuff of Leslie Gulch}

\section{Field Observations}

The tuff of Leslie Gulch is comprised of multiple members, with varying clast size and thicknesses. Facies consist of surge deposits, ash-flow tuffs, fallout tuffs, incipiently welded ignimbrites, and reworked sediments. Intra-caldera facies are dominated by incipiently to densely welded beige to greenish-white tuff with varying sizes of lapilli and ash particles, composing many of the ridges in Leslie Gulch. Outside the presumed southeastern caldera margin, outcrops of fallout and ash-flow tuffs are scattered along the flanks of the caldera and preserved beneath resistant rhyolite lavas. Multiple emplacement units as well as occasionally sedimentary interbeds (Sweeten, 2020 BS Thesis) provide evidence for several, episodic pyroclastic eruptions. In turn, we interpret depositional facies to indicate repetitive phreatomagmatic to magmatic eruptions over a duration of time, resulting in formation of the caldera. 


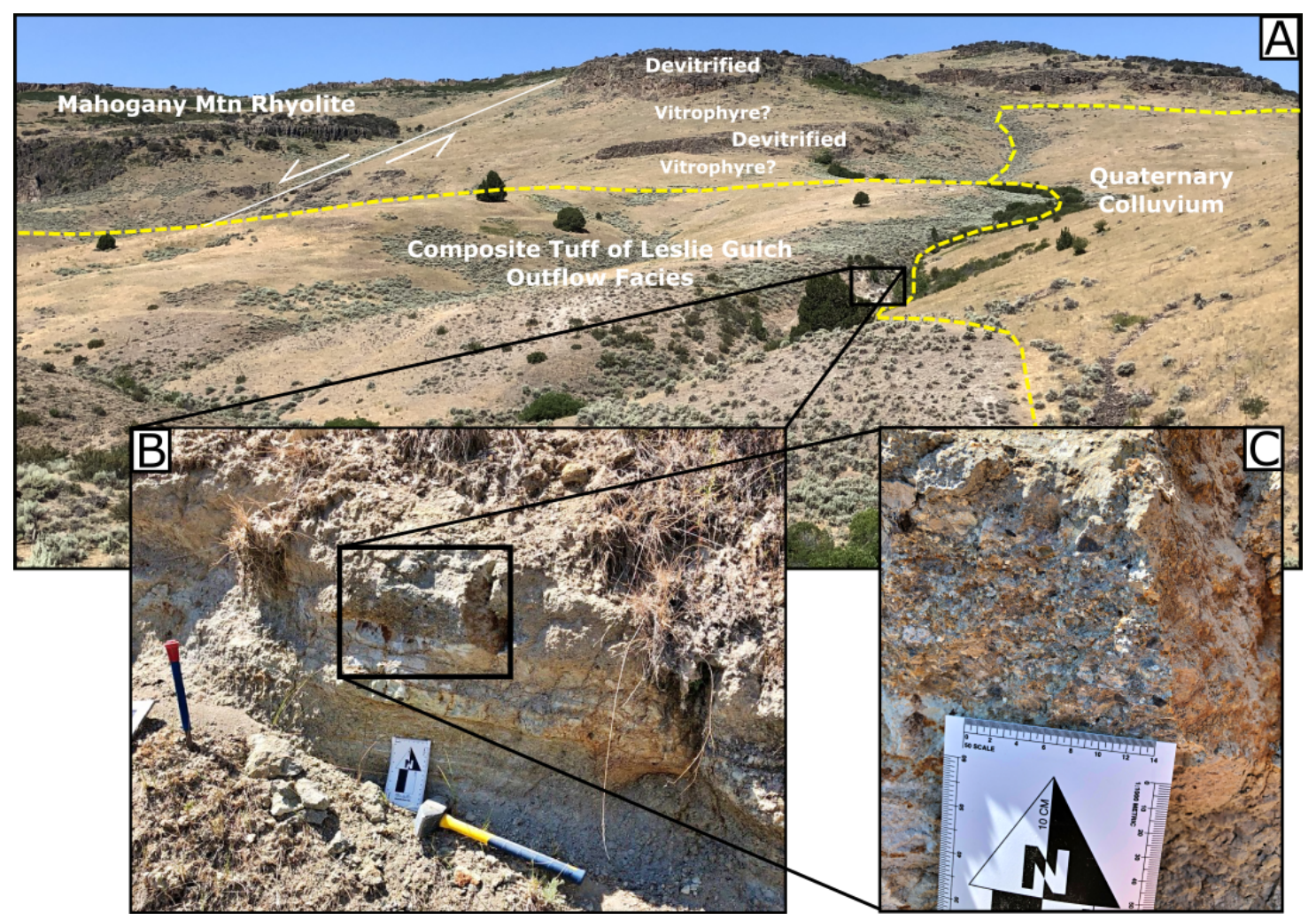

Figure 13. Photograph of composite tuff of Leslie Gulch outcrop featuring an ash-flow tuff member overlying and capping air-fall facies (A). Image B is a closer view of ash-flow tuff member. Location of sample RJ-18-28, ash-flow tuff component of composite tuff of Leslie Gulch.

A small stratigraphic exposure was located on the southeastern flank of Mahogany Mountain, which consisted mostly of reworked tuffaceous sediments, and thin fallout tuffs, capped by a lapilli-rich ash-flow tuff (Fig. 13). The ash-flow tuff (sample RJ-18-28) contains lapilli-sized clasts of 1) lithic fragments, 2) pumiceous and vesiculated glass, 3) dense spherical glass, and 4) $<1-2 \mathrm{~mm}$ angular to subangular sanidine crystals (Fig. 14). The ash-flow tuff is approximately $25 \mathrm{~cm}$ thick, forming a more resistant cap rock over less resistant fallout facies and reworked tuffaceous sediments. Beneath the ash-flow tuff, lies a bed of fine ash of medium thickness $(\sim 23 \mathrm{~cm})$. The tuffaceous facies observed at this exposure were stratigraphically beneath surrounding rhyolite lava domes of the Mahogany Mountain rhyolite. 
Stratigraphically beneath the ash-flow tuff, we observe a transition downward to fine-ash, suggesting this ash-flow eruption was subsequent to a more explosive event with higher degrees of fragmentation, producing the thinly-bedded ash beneath the ashflow tuff member (Fig.13B). Lithologically, we observe a transition from high fragmentation and explosivity to waning eruption intensity with emplacement of the fineash bed and subsequent ash-flow tuff, with no evidence of sedimentation or weathering in between the tuff members (Fig. 14).

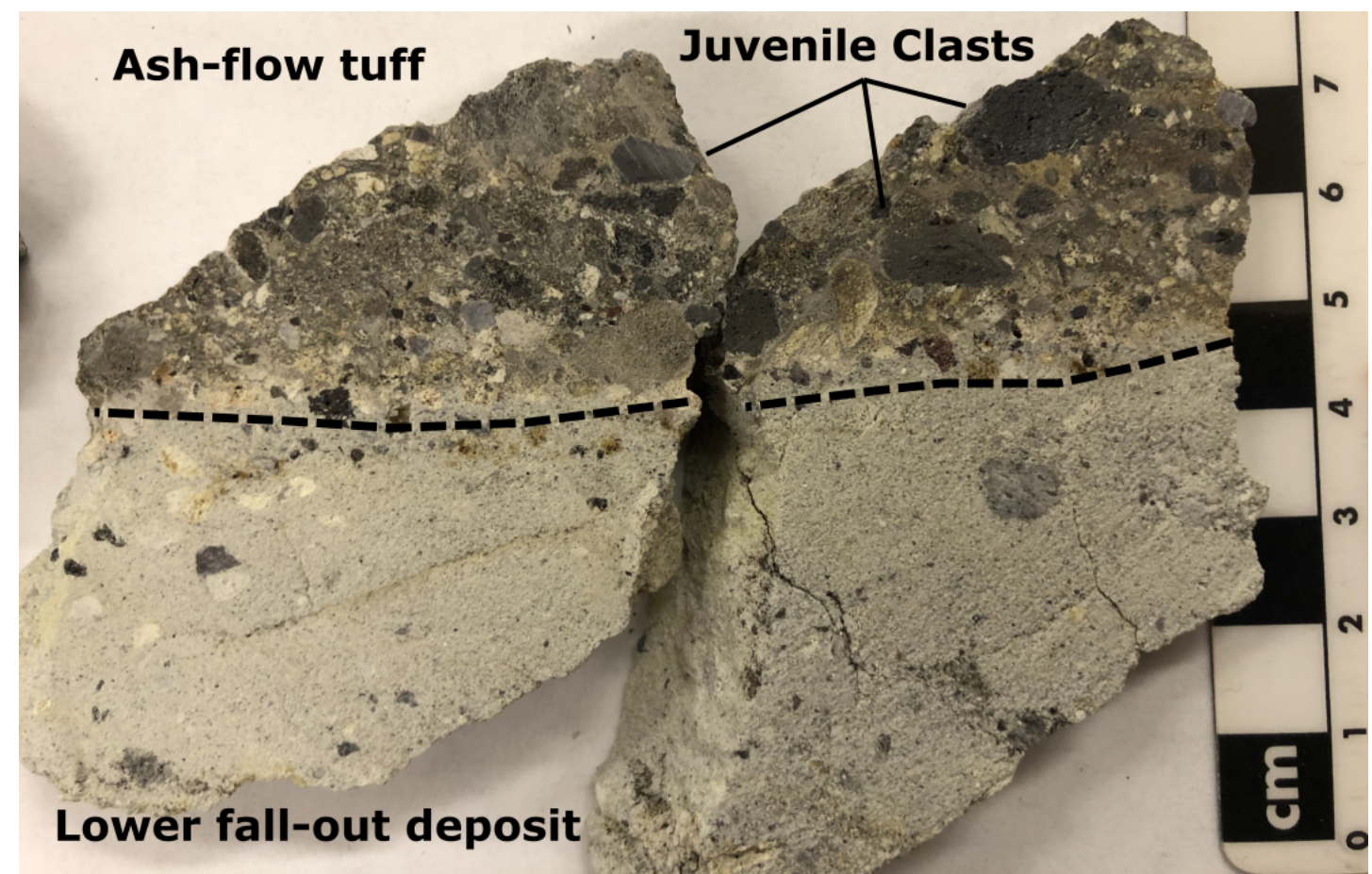

Figure 14. Photograph of ash-flow tuff sample number RJ-18-28, depicting clast supported matrix and underlying fall-out facies.

\section{Geochemistry \& Petrography}

The ash-flow tuff sample was found to contain angular, fragmented, or subhedral feldspars of low-sanidine $\left(\mathrm{An}_{2-1} \mathrm{Ab}_{58-52} \mathrm{Or}_{48-40}\right)$ and labradorite-andesine ( $\mathrm{An}_{62-48} \mathrm{Ab}_{49-37}$ $\mathrm{Or}_{2}$ ) composition (Fig. 15), with clasts of lithics, glass, and pumice in a matrix of ash

(Fig. 14). Sanidine crystals are very sparse, composing $<1 \%$ by volume. 


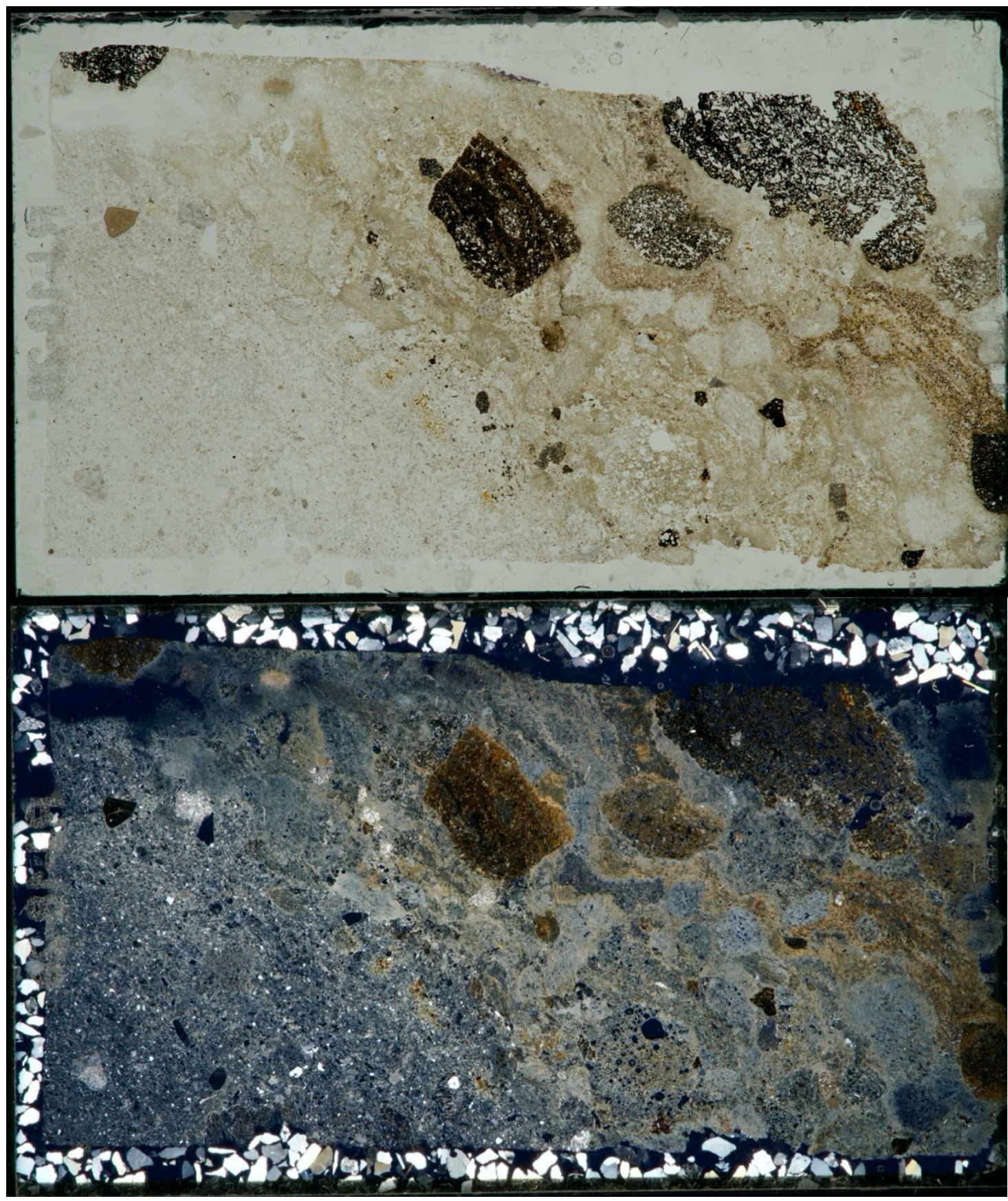

Figure 15. Photomicrographic image of ash-flow tuff member of the composite tuff of Leslie Gulch in thin section, sample: RJ-18-28. To the left, is the stratigraphically lower and more fragmented ash layer, and to the right is the overlying ash-flow tuff layer. 
The ash-flow tuff sample of the composite tuff of Leslie Gulch is classified as a dacite (63 wt. \% $\mathrm{SiO}_{2}$ ) according to the total alkali silica diagram (Le Bas et al., 1985). Bulk composition indicates high $\mathrm{TiO}_{2}(1.58$ wt. \%), $\mathrm{FeO}$ * (9.95 wt. \%), and $\mathrm{MgO}(1.62$ wt. \%). Trace element characteristics display a positive Ba peak (Fig. 18) and a shallow Eu anomaly (Fig. 19), and overall lower incompatible trace element concentrations compared to rhyolites.

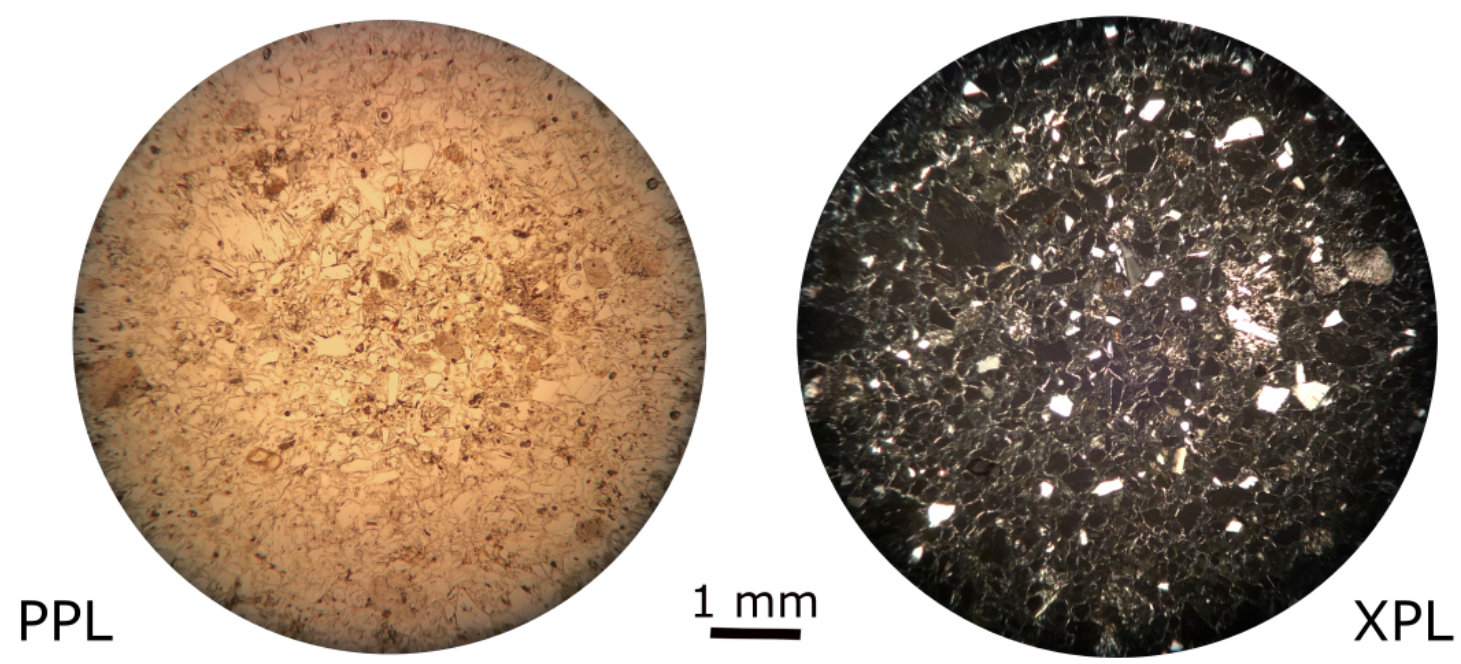

Figure 16. Photomicrographic image of ash-flow tuff member of the composite tuff of Leslie Gulch. In view are fragmented feldspars phenocrysts within a pyroclastic matrix. Ash-flow tuff sample, RJ-18-28. 


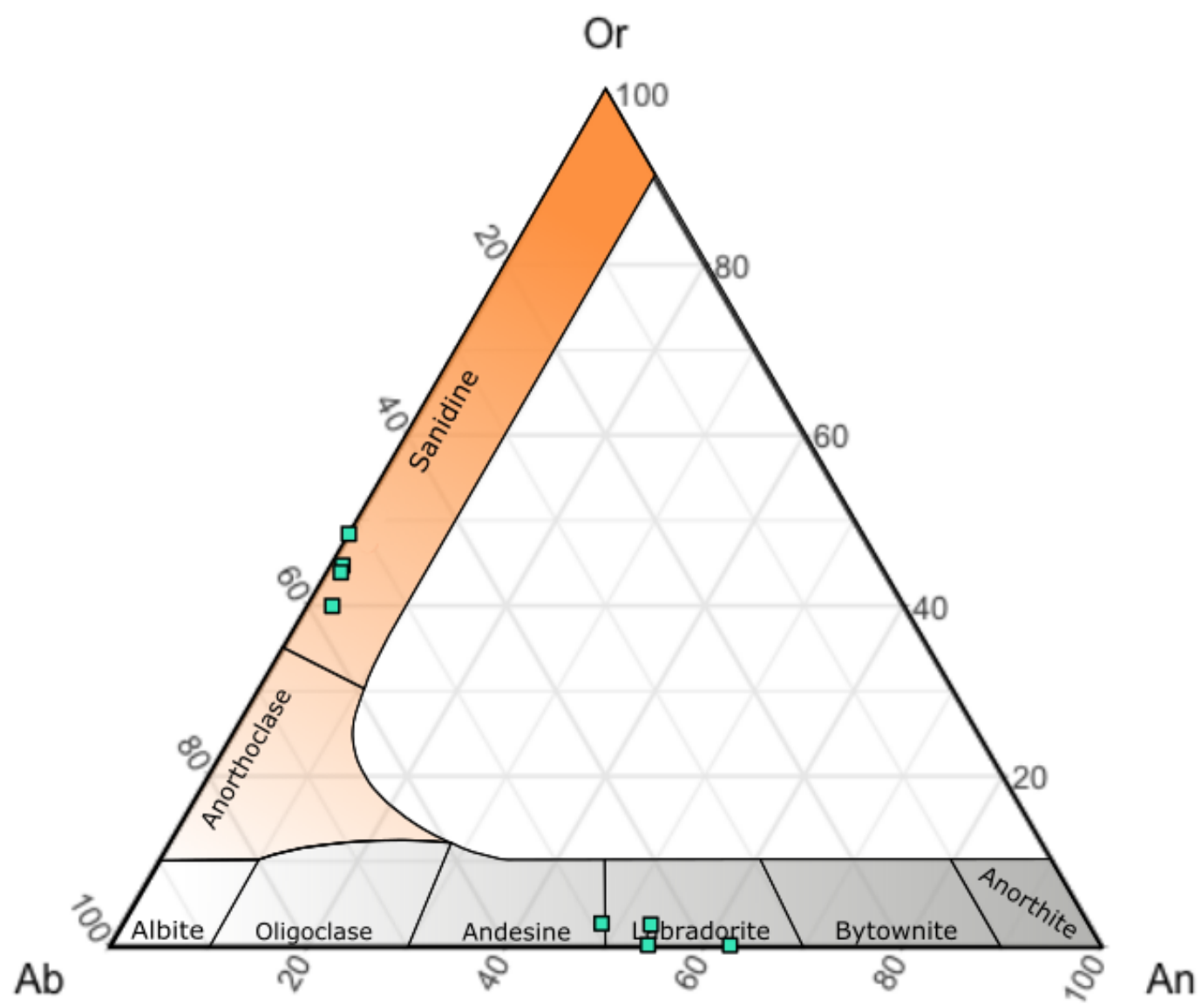

Figure 17. Ternary plot displaying the range of calculated end-member compositions from scanning electron microscope (SEM) analyses of feldspar phenocrysts of the composite tuff of Leslie Gulch samples. Ash-flow tuff sample number: RJ-18-28.

Table 2. The average, minimum, and maximum calculated end-member compositions from scanning electron microscope (SEM-EDX) analyses of Leslie Gulch ash-flow tuff feldspar phenocrysts. Ashflow tuff sample number: RJ-18-28.

\begin{tabular}{llll}
\hline \hline RJ-18-28 & \%An & \%Ab & \%Or \\
\hline Max & 62.5 & 57.9 & 47.9 \\
Mean & 12.1 & 49.1 & 16.7 \\
Min & 1.2 & 37.5 & 2.4
\end{tabular}




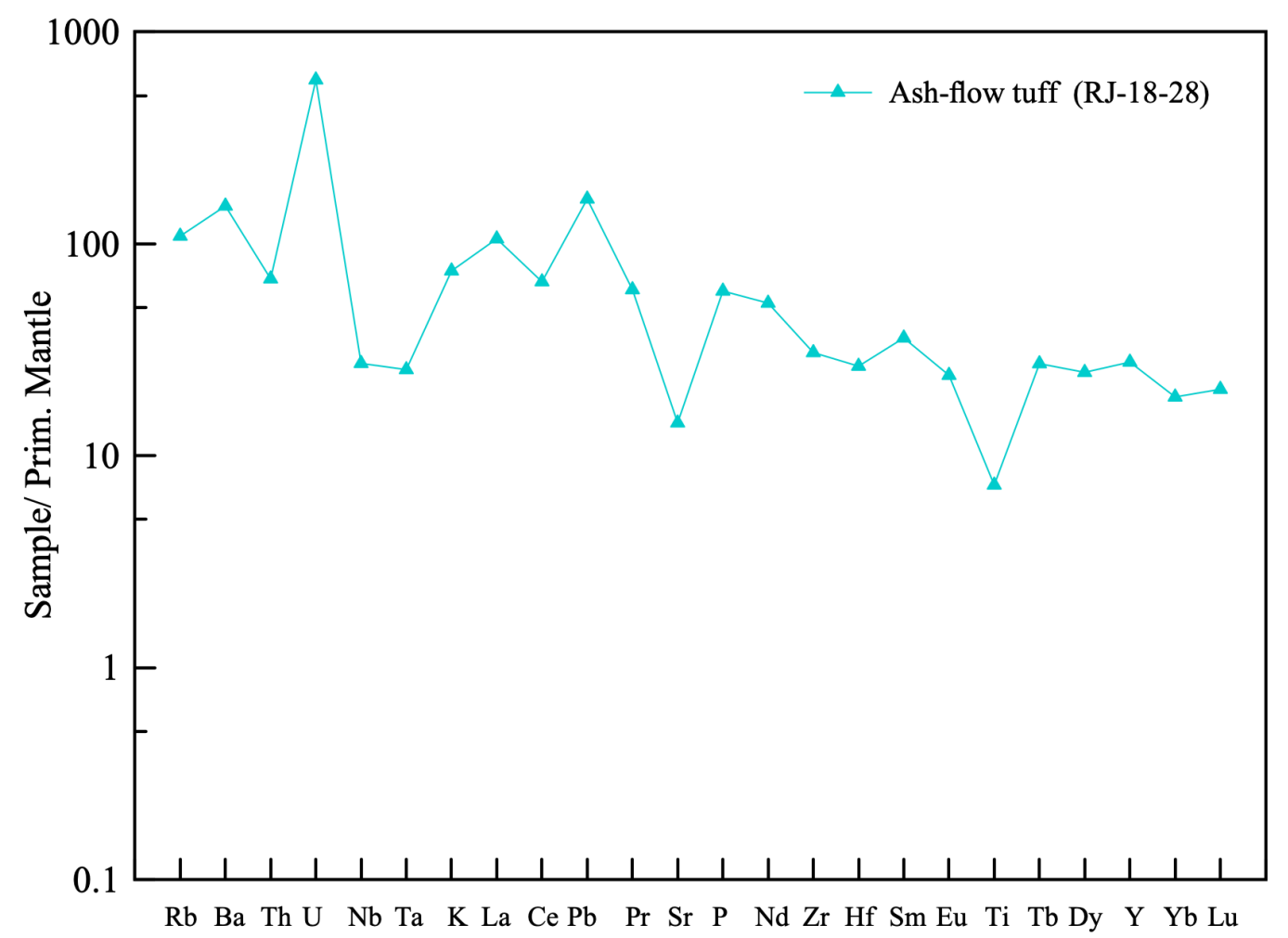

Figure 18. Trace element concentrations for Leslie Gulch ash-flow tuff sample (RJ-18-28). Sample was normalized to primitive mantle, Sun \& McDonough (1989).

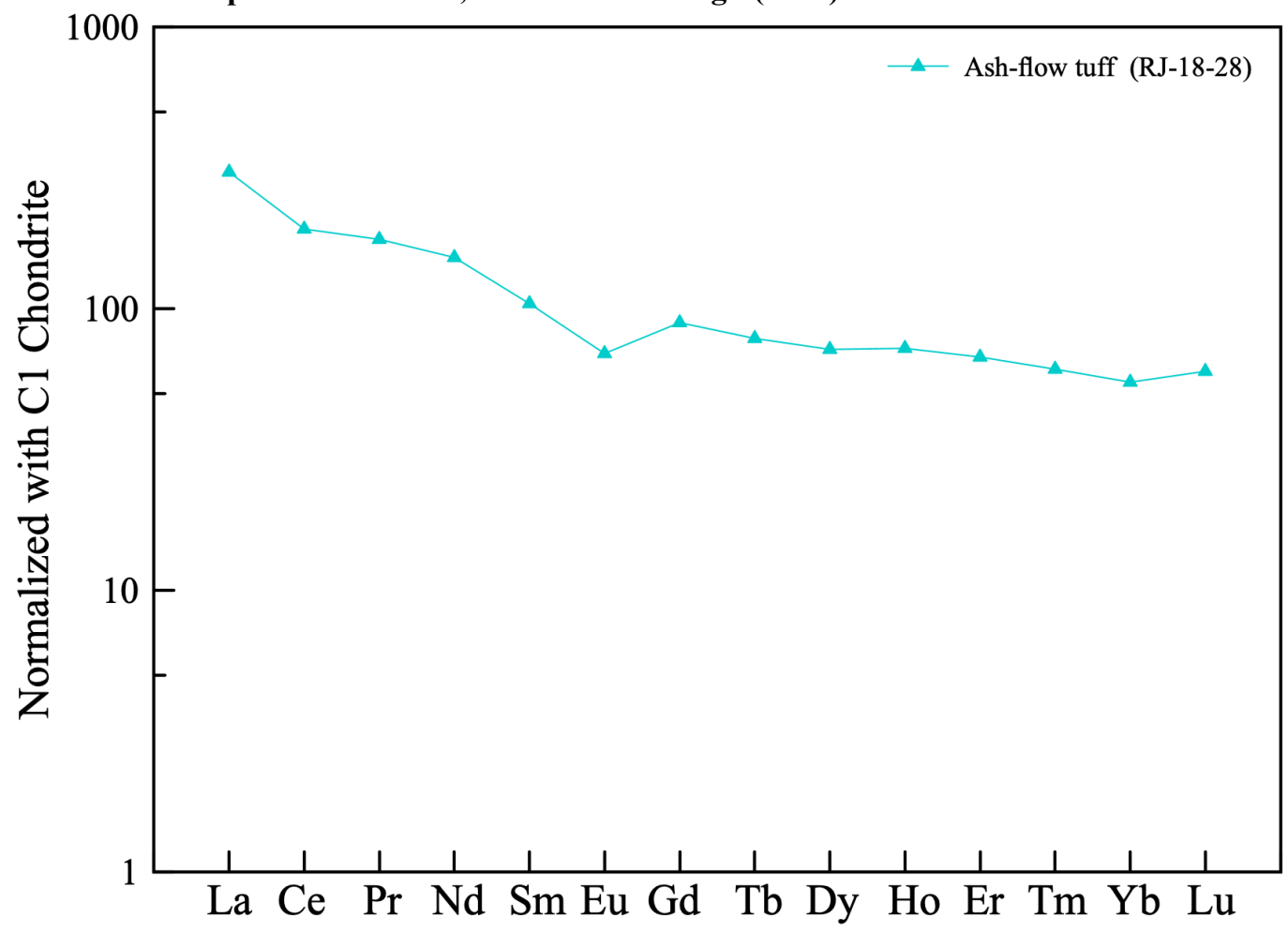

Figure 19. Rare earth element diagram showing samples of the tuff of the Leslie Gulch, normalized to C1 chondrite, McDonough \& Sun (1995). Ash-flow tuff sample: RJ-18-28. 


\subsubsection{Rhyolite SE of Round Mountain}

\section{Field Observations}

In the field, this lava crops out down slope of Round Mountain (Fig. 11). The 'rhyolite SE of Round Mountain' is a porphyritic, crystal-rich lava. Phenocrysts range in size from $1-7 \mathrm{~mm}$ in size and composes $20-22 \%$ by volume. The groundmass is glassy and blueish grey in color. Devitrified facies likely exist but was not observed nor sampled. Spatially the rhyolite crops out just south of the southernmost extent of the Young McIntyre Ridge rhyolite but is geochemically unique to other rhyolite units identified in the area.

\section{Geochemistry \& Petrography}

The 'rhyolite SE of Round Mtn' lava contains euhedral and subhedral sanidine $\left(\mathrm{An}_{3-1} \mathrm{Ab}_{54-46} \mathrm{Or}_{52-46}\right)$ (Fig. 21), subhedral to anhedral quartz, euhedral to subhedral clinopyroxene (En39 $\mathrm{Fs}_{20-19} \mathrm{Wo}_{40}$ ) (Fig. 22), and titanomagnetite, with trace apatite and zircon. Sanidine is the dominant mineral phase featuring sieve texture and simple twinning (Fig. 20). Quartz phenocrysts exhibit resorbed texture with embayments. Perlitic cracks are present in the glass, which is evidence of post-emplacement hydration.

The 'rhyolite SE of Round Mountain' is classified as a high-silica rhyolite ( $\sim 8$ wt. $\% \mathrm{SiO}_{2}$ ). The rhyolite lava displays an evolved signature with 1) high concentrations

of LILEs $\mathrm{Rb}, \mathrm{K}$ and $\mathrm{Pb}, 2$ ) high concentrations of high field strength elements $\mathrm{Th}, \mathrm{Nb}$ and Ta, and 3) depletions of feldspar compatible elements $\mathrm{Ba}, \mathrm{K}, \mathrm{Sr}$ and $\mathrm{Eu}$, along with a low concentration of Ti (Fig. 23). Additionally, the unit exhibits high concentrations of HREEs, and a pronounced Eu anomaly (Fig. 24). 

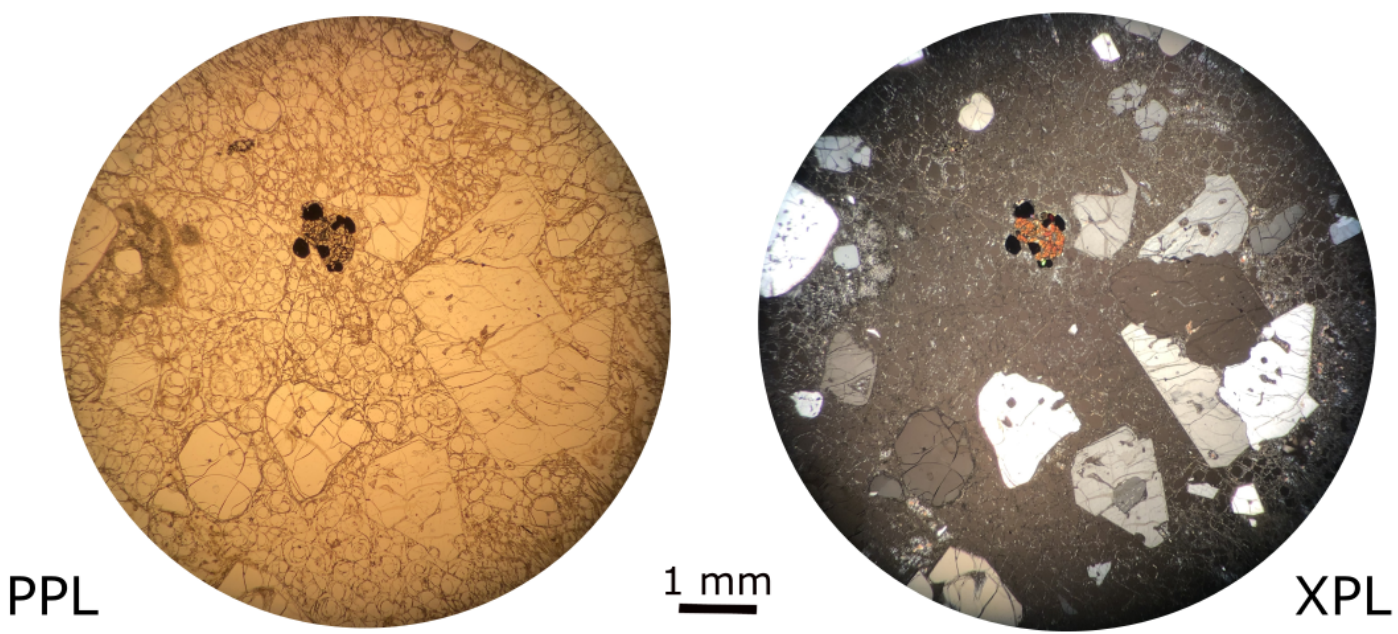

Figure 20. Photomicrographic image of 'rhyolite SE of Round Mtn' in thin section. In view are phenocrysts of sanidine, quartz, clinopyroxene, and titanomagnetite within a vitrophyric groundmass.

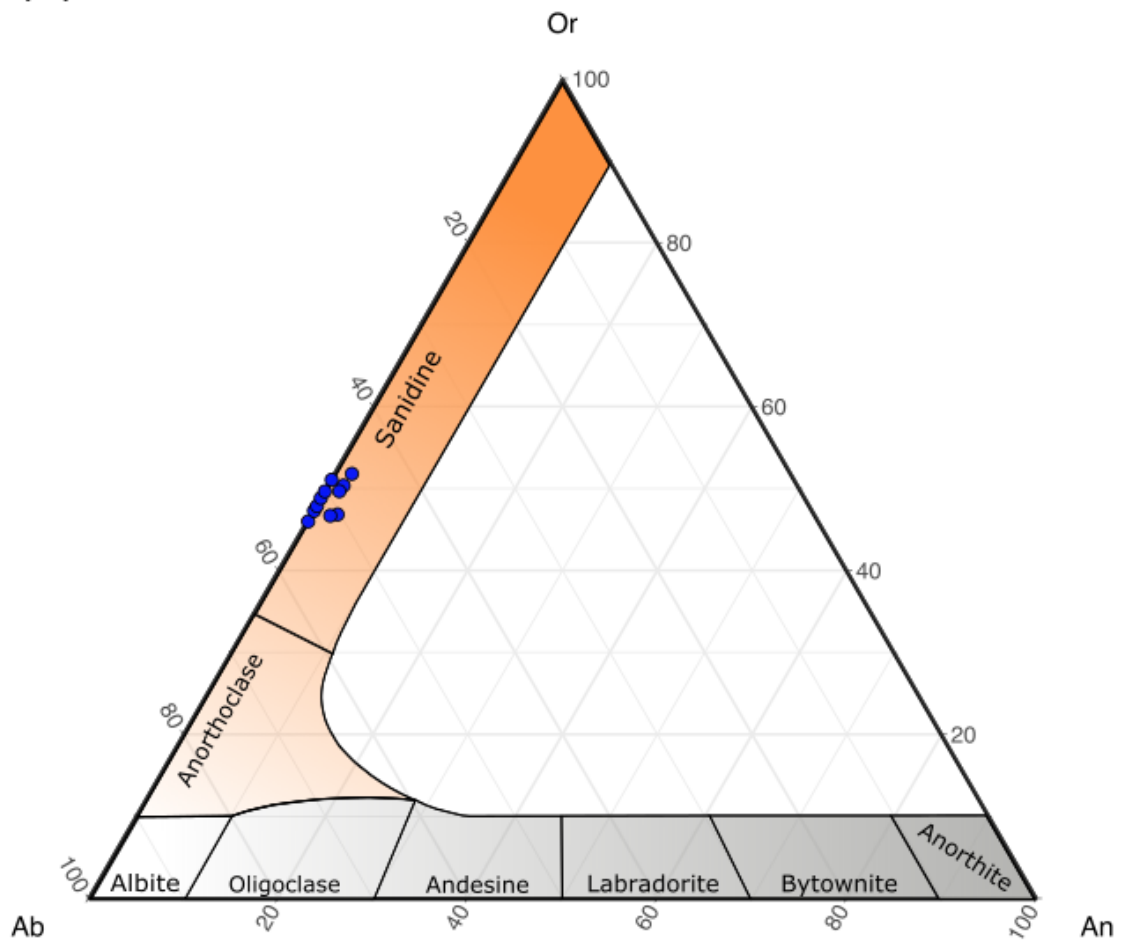

Figure 21. Ternary plot displaying the range of calculated feldspar components from scanning electron microscope data. 'Rhyolite SE of Round Mountain' sample number: RJ-18-05.

Table 3. The average, minimum, and maximum calculated feldspar components from scanning electron microscope (SEM-EDX) data of 'rhyolite SE of Round Mtn' feldspar phenocrysts. 'Rhyolite SE of Round Mtn sample number: RJ-18-05.

\begin{tabular}{llll}
\hline \hline RJ-18-05 & \%An & \%Ab & \%Or \\
\hline Max & 2.9 & 54.0 & 51.7 \\
Mean & 2.0 & 50.2 & 48.8 \\
Min & 1.5 & 46.5 & 46.1 \\
\hline
\end{tabular}




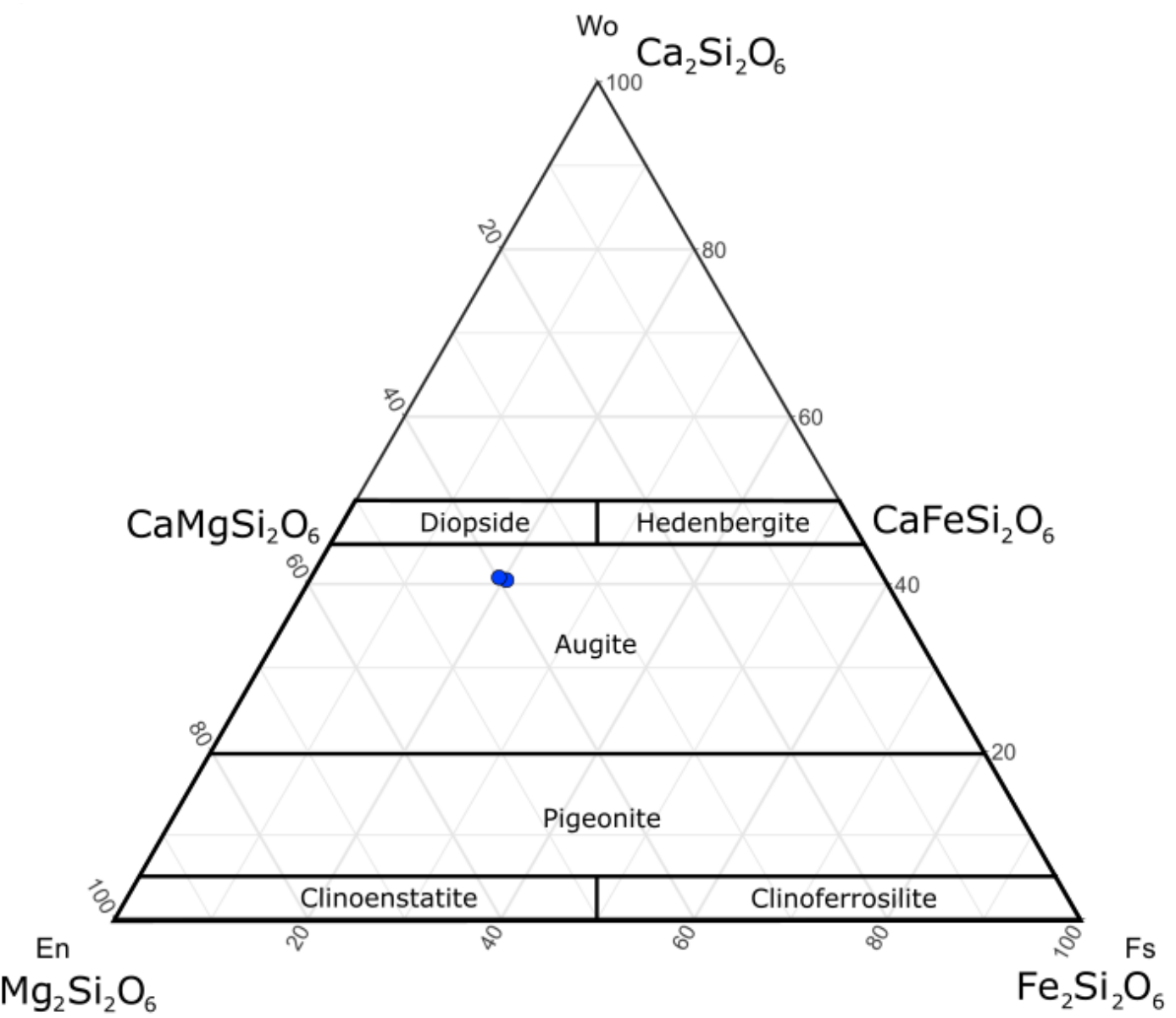

Figure 22. Ternary plot displaying the range of calculated end-member compositions from scanning electron microscope (SEM) of 'Rhyolite SE of Round Mtn' pyroxene phenocrysts, sample number RJ-18-05.

Table 4. The average, minimum, and maximum calculated end-member compositions from scanning electron microscope (SEM-EDX) analyses of 'Rhyolite SE of Round Mtn' pyroxene phenocrysts. 'Rhyolite SE of Round Mtn' sample number: RJ-18-05.

\begin{tabular}{llll}
\hline \hline RJ-18-05 & \%En & \%Fs & \%Wo \\
\hline Max & 39.8 & 20.3 & 40.8 \\
Mean & 39.5 & 19.8 & 40.6 \\
Min & 39.3 & 19.4 & 40.3 \\
\hline
\end{tabular}




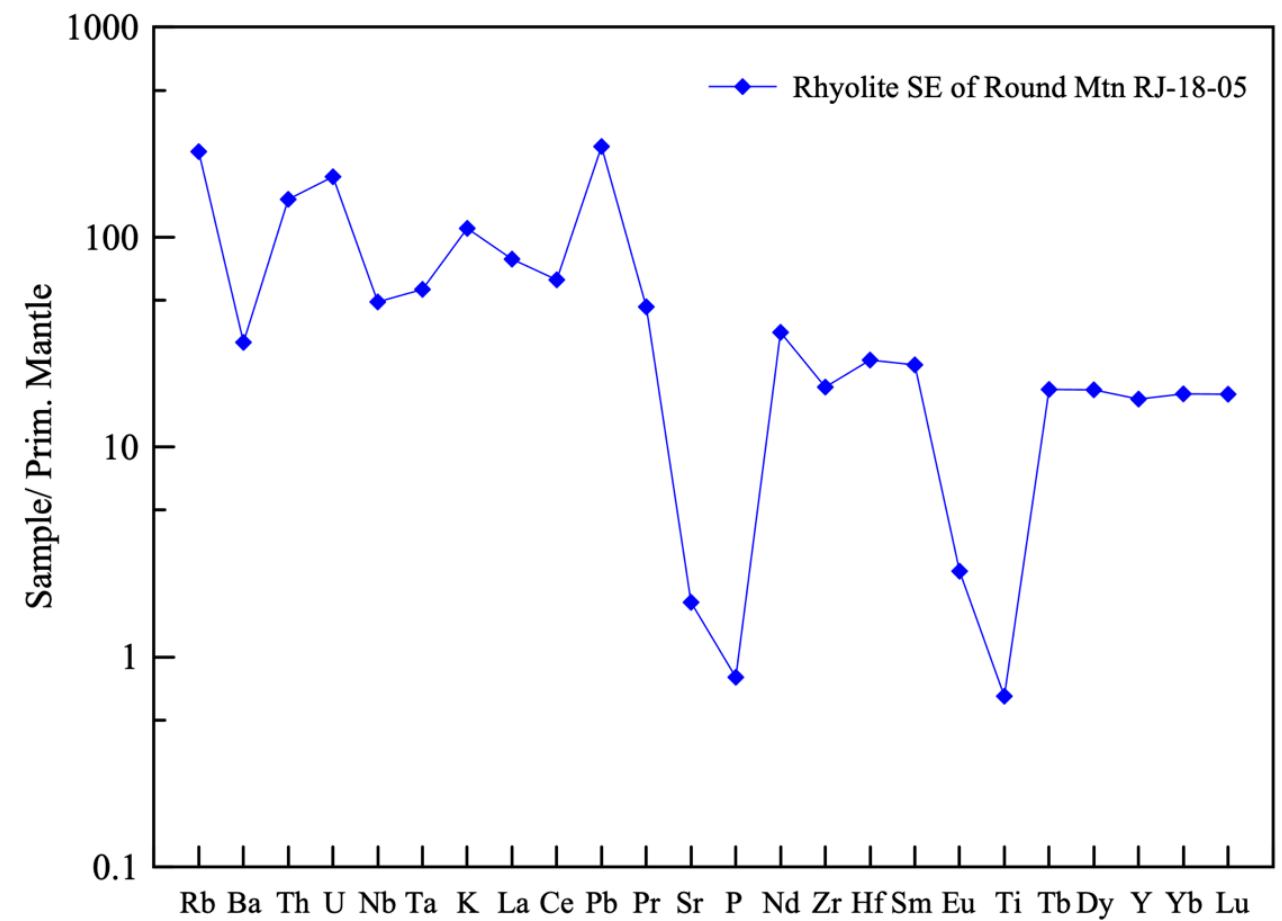

Figure 23. Trace element concentrations for the 'rhyolite SE of Round Mtn', sample number: RJ18-05. Samples were normalized to primitive mantle, Sun \& McDonough (1989).

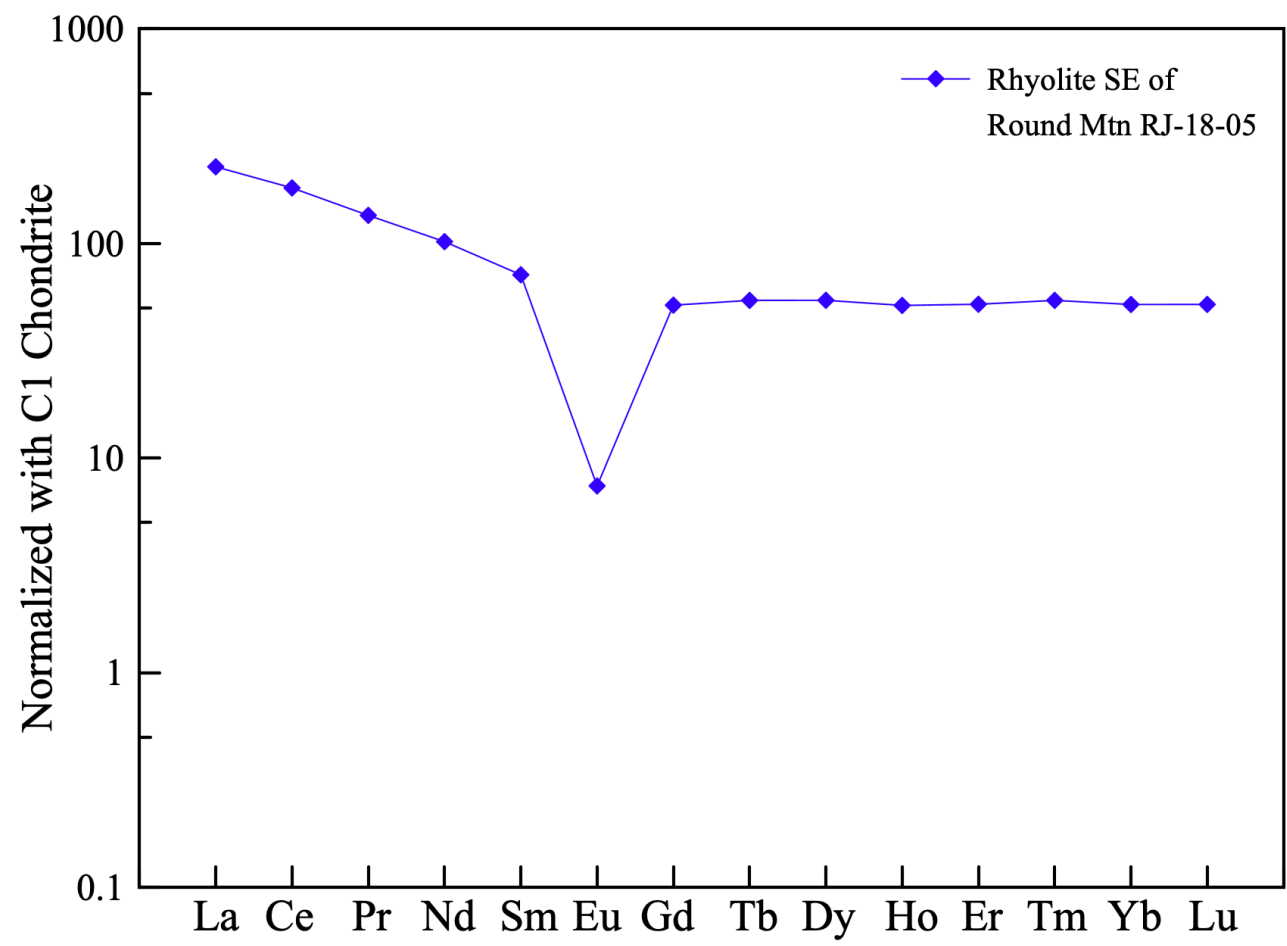

Figure 24. Rare earth element concentrations for 'rhyolite SE of Round Mtn' lava sample normalized to C1 chondrite, McDonough \& Sun (1995). 'Rhyolite SE of Round Mtn' sample number: RJ-18-05. 


\subsubsection{The Mahogany Mountain Rhyolite Suite \\ Field Observations}

The Mahogany Mountain rhyolite (MMR) suite is comprised of porphyritic, crystal-poor rhyolite lavas, which compose several large lava domes along the inferred southeastern margin and flanks of the Mahogany Mountain caldera and cover an area of approximately $75 \mathrm{~km}^{2}$ with an estimated volume of $10.5 \mathrm{~km}^{3}$ (Fig. 11). The sequential accumulation of these lavas make-up the topographic high of the area, named Mahogany Mountain.

The MMR suite consists of at least three geochemically distinct rhyolite flow packages erupting from approximately $15.82 \pm 0.05$ to $15.71 \pm 0.05 \mathrm{Ma}$. Individual flows units were indistinguishable in the field but were later established on mineralogical and geochemical data.

Lava dome characteristics observed range from spiny-type domes with vertically oriented spines and tall, steep sides to more lobate-style domes featuring distinct flow lobes formed by sequential extrusion from the vent, irregular plan forms, and smaller cross-sectional profiles. The main dome is comprised of initial lobate-style domes, with a wider plan view, and subsequently followed by more silica-rich spiny-type dome-forming eruptions. 


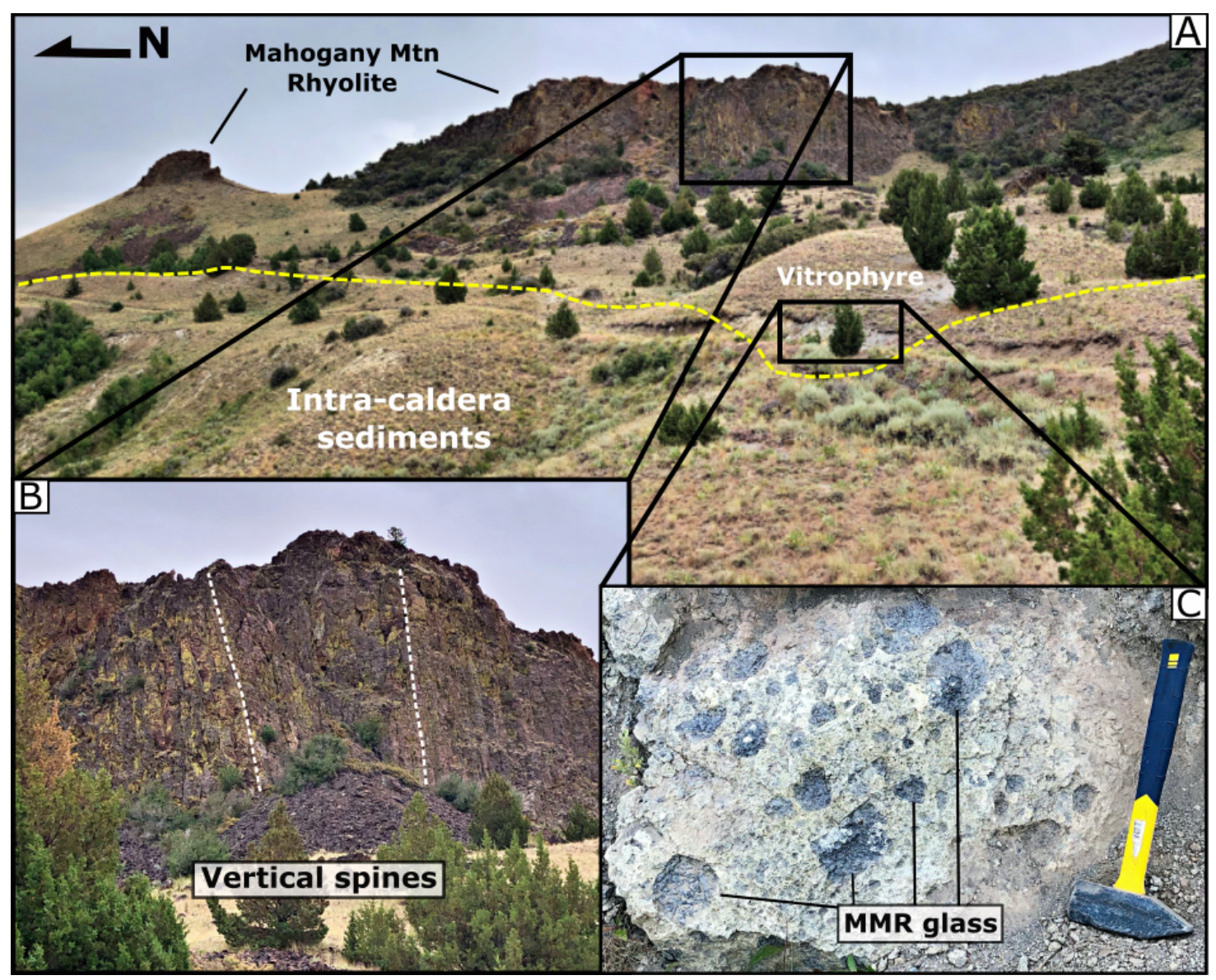

Figure 25. Image A shows a stratigraphic view of the north face of Mahogany Mountain, displaying Flow 3 of the Mahogany Mtn Rhyolite overlying tuffaceous intra-caldera sediments. Image $B$ shows an enlarged view of the vertical spines extruded along caldera ring fractures. Image $C$ displays clasts of glassy rhyolite within the basal breccia of the Mahogany Mountain rhyolite, with a sledgehammer for scale.

Several spiny-type domes were observed on the north face of Mahogany

Mountain, stratigraphically overlying and intruding into the existing intra-caldera lake sediments. A north-facing exposure of Mahogany Mountain dome, approximately $\sim 50 \mathrm{~m}$ thick, features vertical spires of densely devitrified rhyolite lava (Fig. 25b). The other two spiny rhyolite domes were observed extending approximately $1.4 \mathrm{~km}$ northward in a roughly linear trend from the face of the mountain and feature similar lithology and surrounding vitrophyres of eroded grey rhyolite glass (Fig. 26). These vertical spines are evidence of extrusion at these locations, providing evidence for emplacement subsequent 
to formation of the caldera and deposition of intra-caldera sediments. These spiny domes are interpreted to be distal extrusions of MMR magma along fractures in the subsiding caldera floor. The main dome of Mahogany Mountain is interpreted to be vented through the inferred caldera ring fracture, based on its spatial position along the caldera margin, and stratigraphic position above the tuff of Leslie Gulch and intra-caldera sediments.

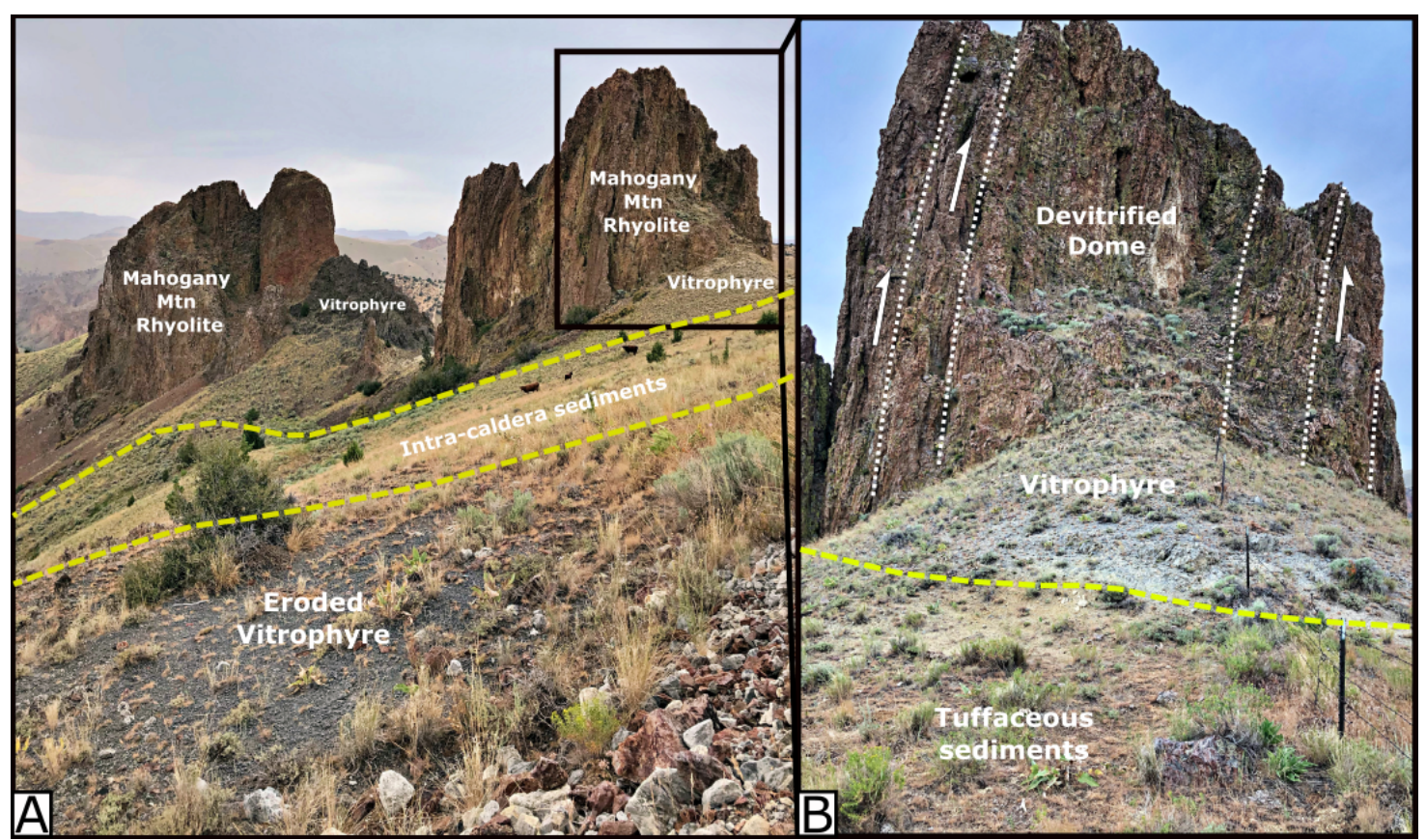

Figure 26. Image A shows two spiny domes of Mahogany Mountain rhyolite vertically extruded into intra-caldera lake sediments, with adjacent vitrophyres; view is looking northeast. Image B shows a closer stratigraphic view of the spiny rhyolite dome with near vertical flow banding, view is looking north.

Lobate-style domes are more commonly observed at more distal extents of the unit, featuring discernible lobes flowing away from the vent and down slope, along the southeastern rim of the Mahogany Mountain caldera. The initial and stratigraphically lowest flow units of the MMR suite exhibit lobate-style emplacement with wider and smoother topography, and evidence of sequential lobe pulsation of emplacement. Stratigraphically, we observe a change in eruptive behavior with a change in dome 
emplacement style to more spiny-type dome emplacement with flow unit 3 (Fig. 26). Geochemical observations will be discussed in greater detail later in this section.

Stratigraphic observations within the caldera feature lava domes of the MMR emplaced onto fine-grained tuffaceous sediments derived from caldera formation. The basal breccia features angular to subangular, dense glassy rhyolite lava clasts entrained within tan, devitrified matrix (Fig. 25C). These tuffaceous sediments were identified above intra-caldera facies of the composite tuff of Leslie Gulch. Deposition of finegrained sediments above intra-caldera tuff suggests a period of sedimentation in the framework of a caldera lake following caldera formation. These observations provide stratigraphic evidence for the MMR being emplaced subsequent to caldera formation. On the southeast flank of the caldera, the MMR was observed to overlie outflow facies of the composite tuff of Leslie Gulch, as well as reworked tuffaceous sediments derived from within the graben. Stratigraphic relationships observed inside and outside of the caldera place eruptions of MMR after eruptions of the composite tuff of Leslie Gulch, and support a post-caldera timing of emplacement.

Outcrop lithologies of the MMR suite feature massive, platy-jointed, or columnarjointed, glassy black to grey-blue vitrophyre, or incipient to fully devitrified rhyolite. Both devitrified and glassy facies have similar mineralogy and geochemistry, and can feature vesicles, flow-banding, and spherulites. In glassy facies, the groundmass color ranges from black in the initial flow to more blue grey with subsequent flows. Phenocrysts in hand sample consist of feldspar and quartz. Glassy material was often observed to exhibit perlitic texture in the groundmass and is known to be a result of hydration following emplacement. Columnar jointing was observed at several outcrops of 
the third flow of MMR, located along the northeast flank of the mountain (Fig. 27).

Columns were approximately $20-40 \mathrm{~cm}$ wide with ranging orientations. For the devitrified facies, flow banding is often reddish-purple, and the groundmass color can vary from light grey to reddish-brown. Vesicularity and alteration vary widely within the extents of the unit. Many of the free-standing structures possessed high vesicle abundance and evidence of secondary mineralization of quartz within vesicles present. Spherulite abundance and size were observed to range from $<1-4 \mathrm{~mm}$ in size. Commonly, the dense devitrified material would form the cap to high standing features due to its more resistant nature as compared with glassy material (Fig. 27).

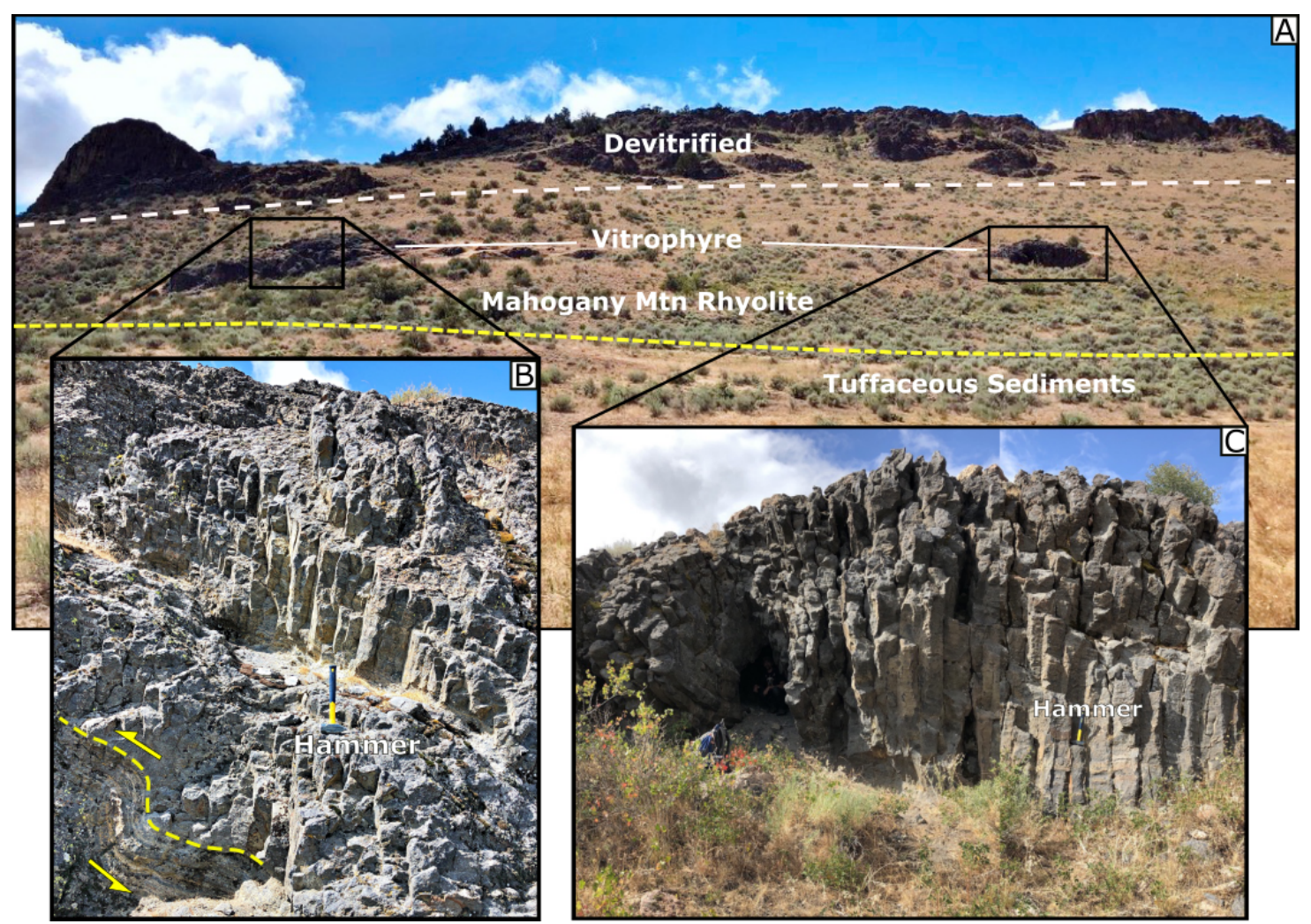

Figure 27. Image A displays the stratigraphy of the MMR dome on the northeast flank of the mountain with outcrops of vitrophyre and the approximate contact with underlying tuffaceous sediments. Image B displays an outcrop featuring columnar-jointing and flow banding within the MMR vitrophyre. Image $C$ displays an additional outcrop featuring columnar-jointing within MMR vitrophyre. A 4 lb. sledgehammer is used for scale in Images B \& C. 


\section{Geochemistry \& Petrography}

Samples are porphyritic with approximately 2-6 \% phenocrysts, containing subhedral to anhedral alkali and plagioclase feldspars, euhedral to subhedral clinopyroxene, anhedral quartz, titanomagnetite, apatite, and zircon within a vitric or devitrified groundmass. Feldspars are the dominant mineral phase and range from $<1-5$ $\mathrm{mm}$ in size. Though all three flow units are crystal-poor, we observe a slight increase in phenocryst content within the MMR suite through time. The first two flow units have similar phenocryst volumes of $2-3 \%$, while flow unit 3 shows an increase in phenocryst abundance (5-6\%) and size (Fig. 29). Plagioclase feldspars are oligoclase $\left(\mathrm{An}_{26-24} \mathrm{Ab}_{69-68}\right.$ $\left.\mathrm{Or}_{6-5}\right)$, while alkali feldspars range from anorthoclase to low-sanidine $\left(\mathrm{An}_{12-1} \mathrm{Ab}_{69-47} \mathrm{Or}_{53-}\right.$ 19). With progressive flow emplacement, we observe an evolution through time from oligoclase to sanidine (Fig. 31). Clinopyroxenes display compositions ranging from

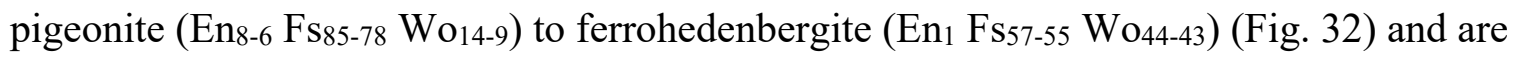
observed to be larger and more abundant in flow unit 3 than previous flow units (Fig. 29). 


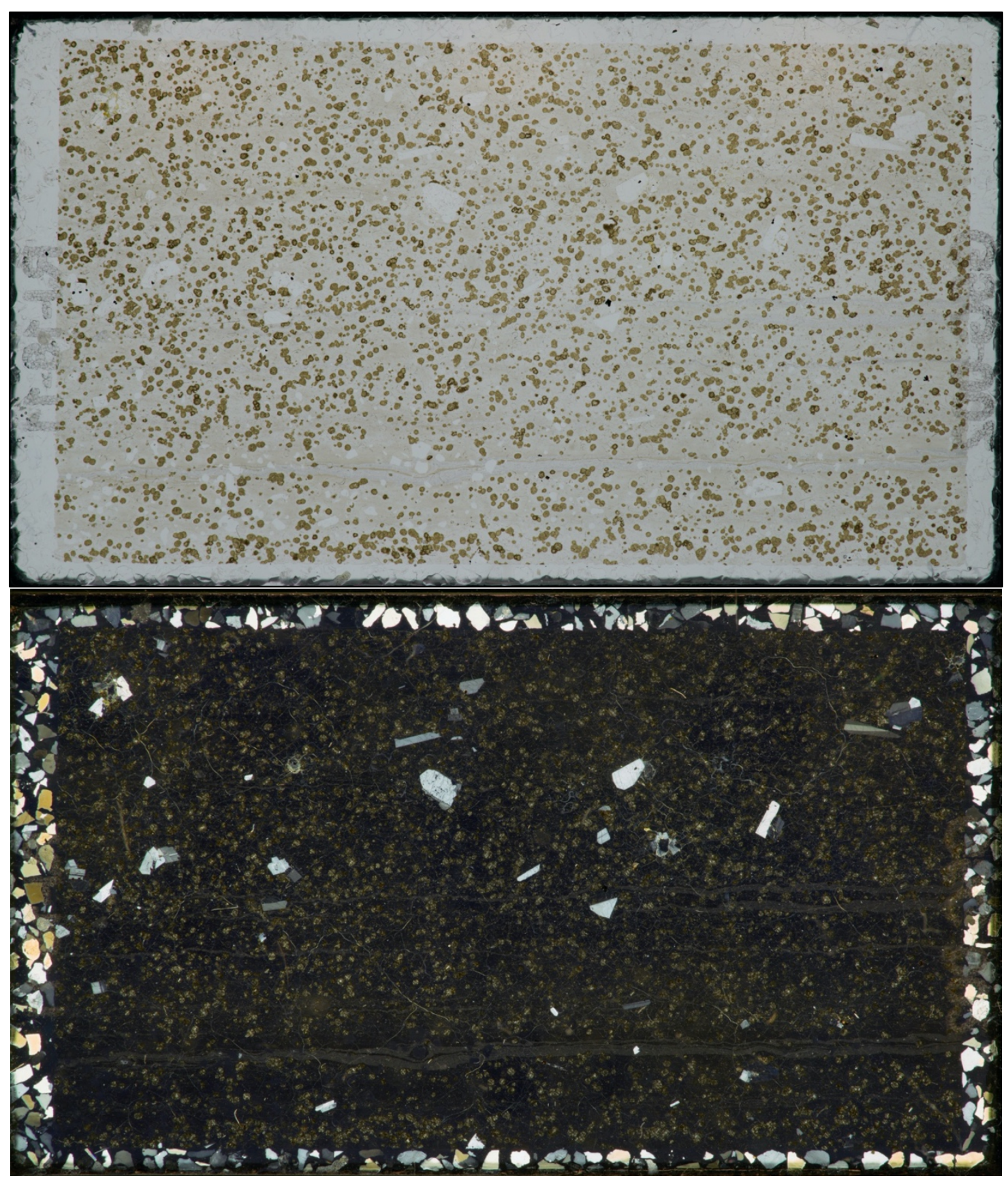

Figure 28. Photomicrographs of sample RJ-18-11 of the Mahogany Mountain rhyolite, flow unit 1, in thin section. Top image is displayed in plane-polarized light and the bottom image is displayed in cross-polarized light. In view are phenocrysts of Oligoclase, clinopyroxene, titanomagnetite, and accessory apatite and zircon within a vitrophyric groundmass. Spherulites are present as secondary product within the groundmass. 


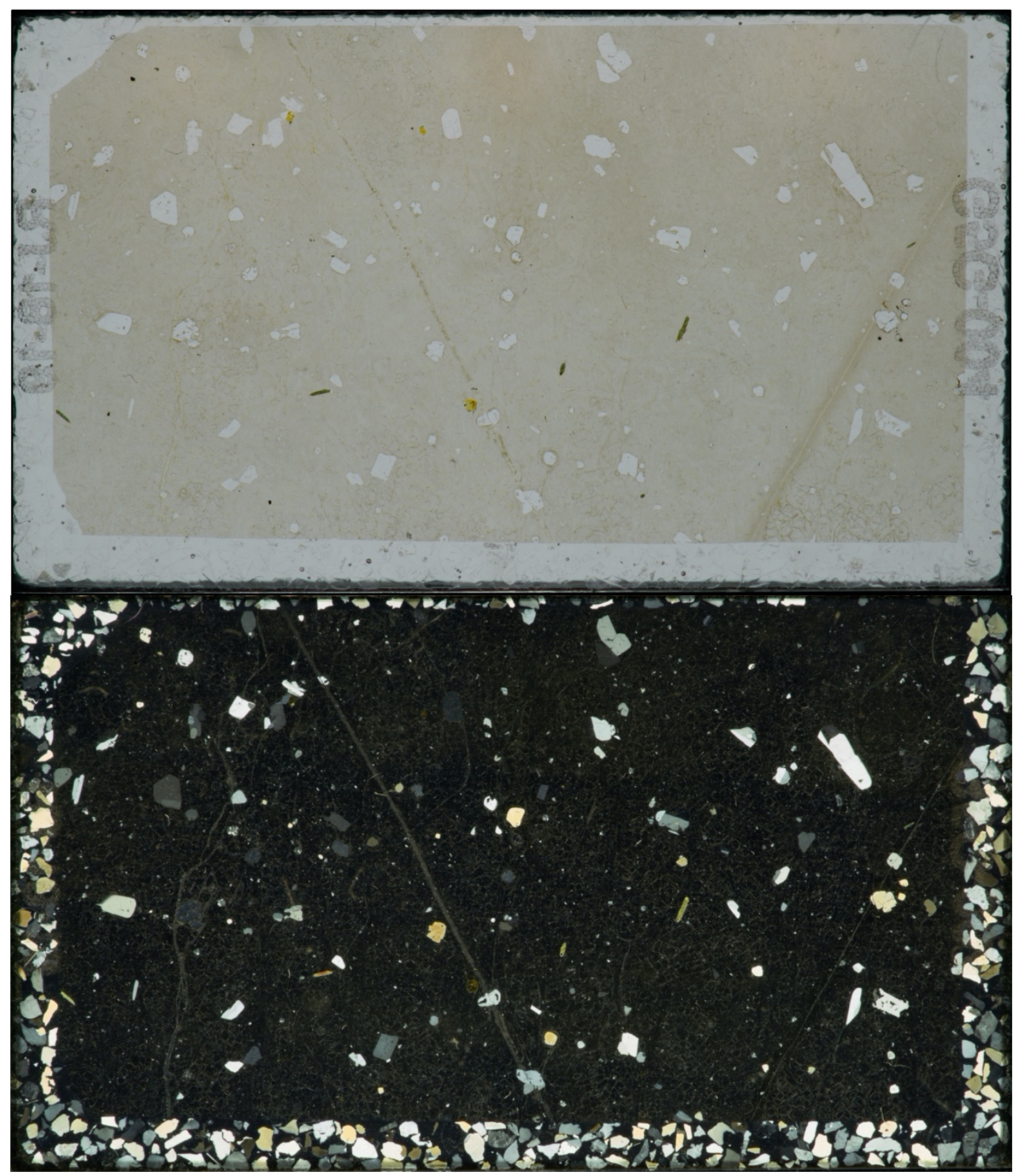

Figure 29. Photomicrographs of sample RJ-18-19 of the Mahogany Mountain rhyolite, flow unit 3, in thin section. Top image is displayed in plane-polarized light and the bottom image is displayed in cross-polarized light. In view are phenocrysts of sanidine, clinopyroxene, titanomagnetite, and accessory apatite and zircon within a vitrophyric groundmass. 
Though often indistinguishable in the field, our data reveals the MMR consists of three geochemically distinct rhyolite flows units, designated here as 'flow unit 1', 'flow unit 2', and 'flow unit 3'. These flows are distinguished by $\mathrm{Ba}, \mathrm{Eu}, \mathrm{Zr}, \mathrm{Nb}, \mathrm{Ta}, \mathrm{Yb}$, and $\mathrm{TiO}_{2}$ (Fig. 33). ${ }^{40} \mathrm{Ar} /{ }^{39} \mathrm{Ar}$ ages also show a range from $15.82 \pm 0.05 \mathrm{Ma}$ to $15.71 \pm 0.05$ Ma, respectively. Age dates for flow unit 1 and flow unit 2 are within error of one another and are considered with stratigraphic relationships and geochemical evolutionary trends, supporting an eruptive sequence of this nature (Table 1, Fig 30). Geochemically, the MMR is a high-silica rhyolite, with silica content ranging from $\sim 74$ to 79 wt. $\% \mathrm{SiO}_{2}$, increasing with time and subsequent flow units. Several devitrified samples within the sample suite of this study contain $>79.0 \mathrm{wt} . \% \mathrm{SiO}_{2}$, this is attributed to a slight secondary gain of silica and hence have been excluded from geochemical assessments to preserve a more accurate representation of Mahogany Mountain rhyolite lava geochemical signatures. 


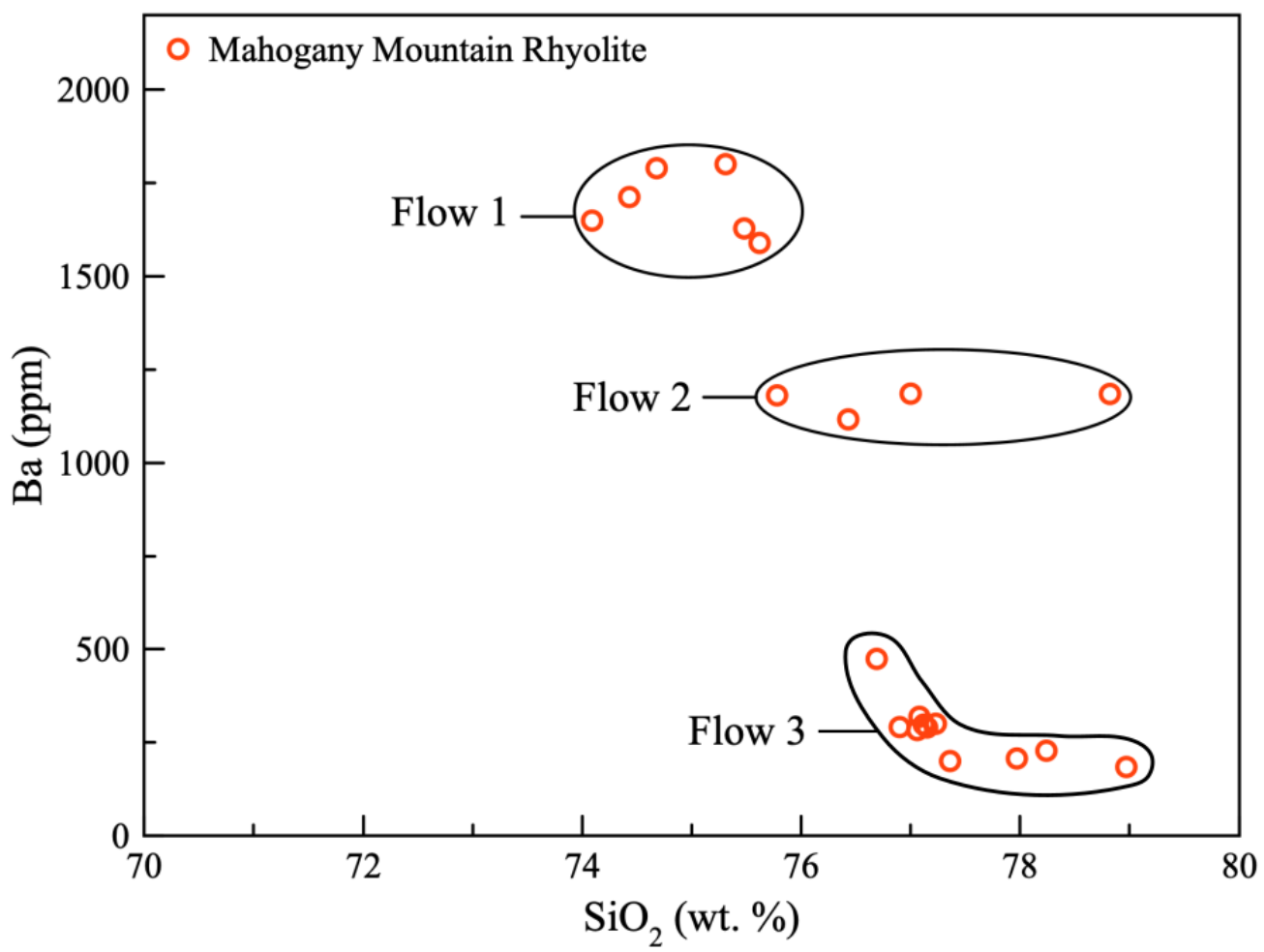

Figure 30. Bivariate plot of $\mathrm{SiO}_{2}$ (wt. \%) vs Barium (ppm) for flow units of the Mahogany Mtn rhyolite. Here we can see the Mahogany Mountain rhyolite in red circles, show depletion in Ba concentration with successive flow units and increasing silica content.

Barium has been found to be the best trace element for distinguishing between flow units, showing groupings with concentrations varying from $\sim 1600 \mathrm{ppm}, \sim 1100 \mathrm{ppm}$, and $2300 \mathrm{ppm}$ (Fig. 30). Ba, Eu and Sr concentrations are observed to decrease with time and successive flows (Fig. 33), increasing the Eu anomaly with time (Fig. 34). While concentrations of more incompatible elements such as $\mathrm{Nb}$ and $\mathrm{Ta}$, and concentrations of heavy rare earth elements increase with successive flows and time (Fig. 34). 


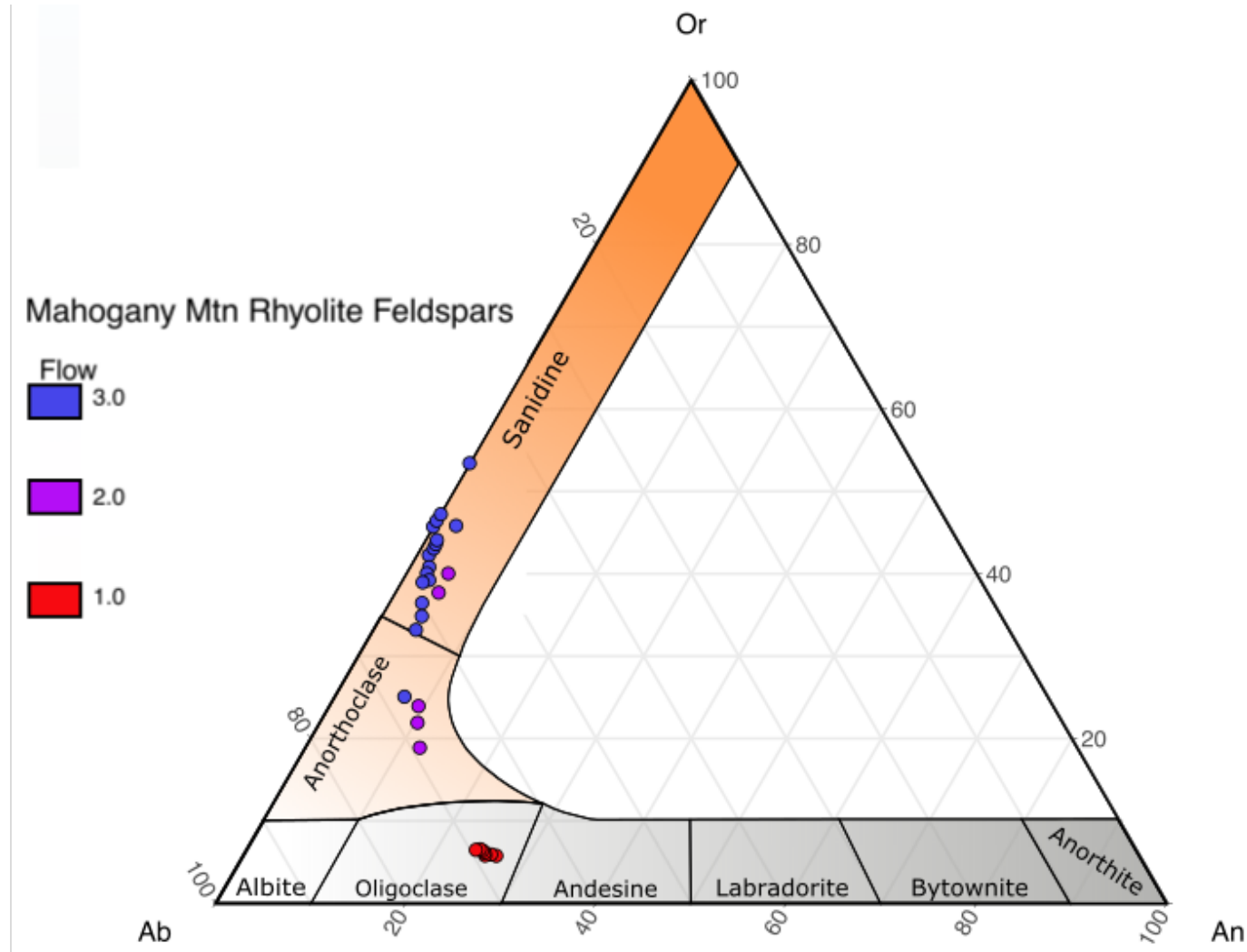

Figure 31. Ternary plot displaying the range of calculated feldspar components from scanning electron microscope data of Mahogany Mountain rhyolite feldspar phenocrysts. Feldspars of flow unit 1 are shown in red, flow unit 2 in purple, and flow unit 3 in blue.

Table 5. The average, minimum, and maximum calculated feldspar components from scanning electron microscope data of Mahogany Mtn rhyolite feldspar phenocrysts. Rhyolite samples were grouped by flow: flow unit 1 , flow unit $2, \&$ flow unit 3 .

\begin{tabular}{llll}
\hline \hline Flow Unit 1 & \%An & \%Ab & \%Or \\
\hline Max & 26.6 & 69.4 & 6.6 \\
Mean & 25.1 & 68.7 & 6.2 \\
Min & 24.1 & 67.7 & 5.7 \\
Flow Unit 2 & & & \\
\hline Max & 12.1 & 69.1 & 40.1 \\
Mean & 7.5 & 63.1 & 27.2 \\
Min & 4.4 & 55.5 & 18.9 \\
Flow Unit 3 & & & 53.4 \\
\hline Max & 7.3 & 67.6 & 40.3 \\
Mean & 2.5 & 57.0 & 25.1 \\
Min & 1.2 & 46.6 & \\
\hline
\end{tabular}




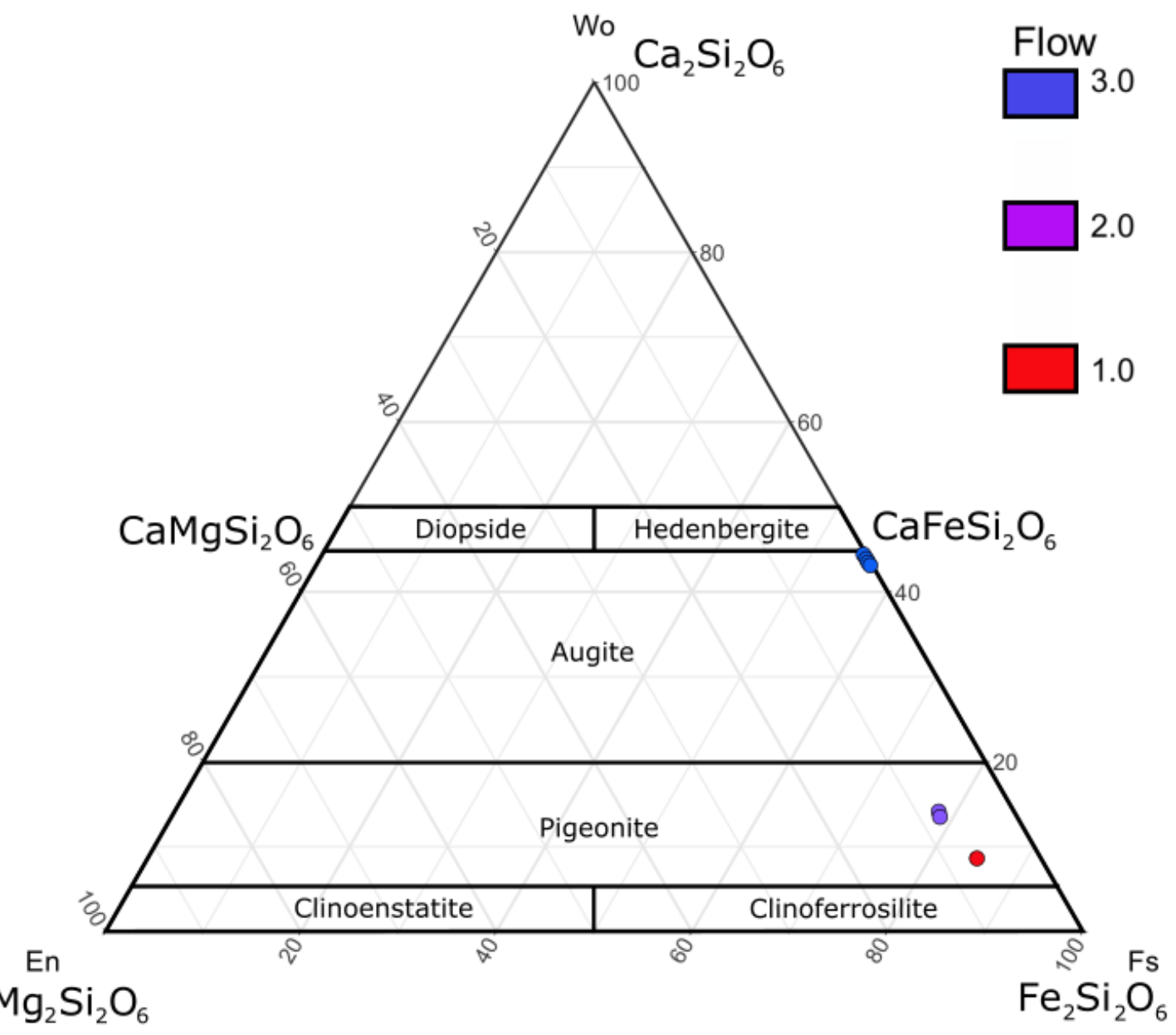

Figure 32. Ternary plot displaying the range of calculated pyroxene components from scanning electron microscope (SEM) and electron microprobe analyses of Mahogany Mountain rhyolite pyroxene phenocrysts. Pyroxenes of flow unit 1 are shown in red, flow unit 2 in purple, and flow unit 3 in blue.

Table 6. The average, minimum, and maximum calculated pyroxene components from scanning electron microscope and electron microprobe data of MMR pyroxene phenocrysts. Rhyolite samples were grouped by flow: flow unit 1 , flow unit $2, \&$ flow unit 3 .

\begin{tabular}{llll}
\hline \hline Flow Unit 1 & \%En & \%Fs & \%Wo \\
\hline RJ-18-11 & 6.7 & 84.6 & 8.7 \\
Flow Unit 2 & & & 14.1 \\
\hline Max & 7.9 & 78.5 & 13.8 \\
Mean & 7.8 & 78.3 & 13.6 \\
Min & 7.8 & 78.1 & \\
Flow Unit 3 & & & 44.3 \\
\hline Max & 0.2 & 56.7 & 43.9 \\
Mean & 0.2 & 55.9 & 43.2 \\
Min & 0.1 & 55.5 & \\
\hline
\end{tabular}




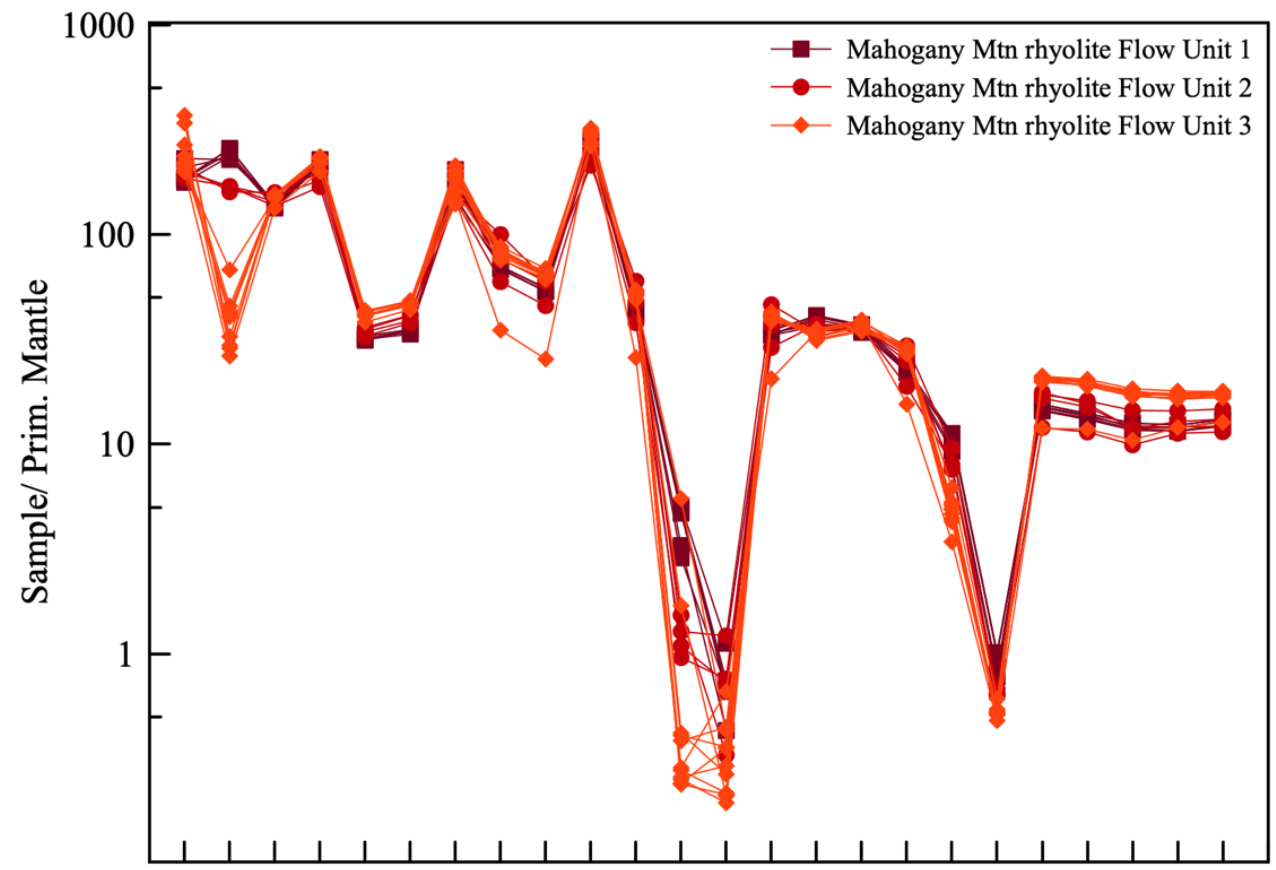

$\mathrm{Rb} \mathrm{Ba}$ Th U Nb Ta K La Ce Pb Pr Sr P Nd Zr Hf Sm Eu Ti Tb Dy Y Yb Lu

Figure 33. Trace element concentrations of Mahogany Mountain rhyolite samples. Samples of Flow unit 1 are designated as burgundy squares, samples from flow unit 2 are dark red circles, and samples of flow unit 3 red diamonds. Samples were normalized to primitive mantle, Sun \& McDonough (1989).

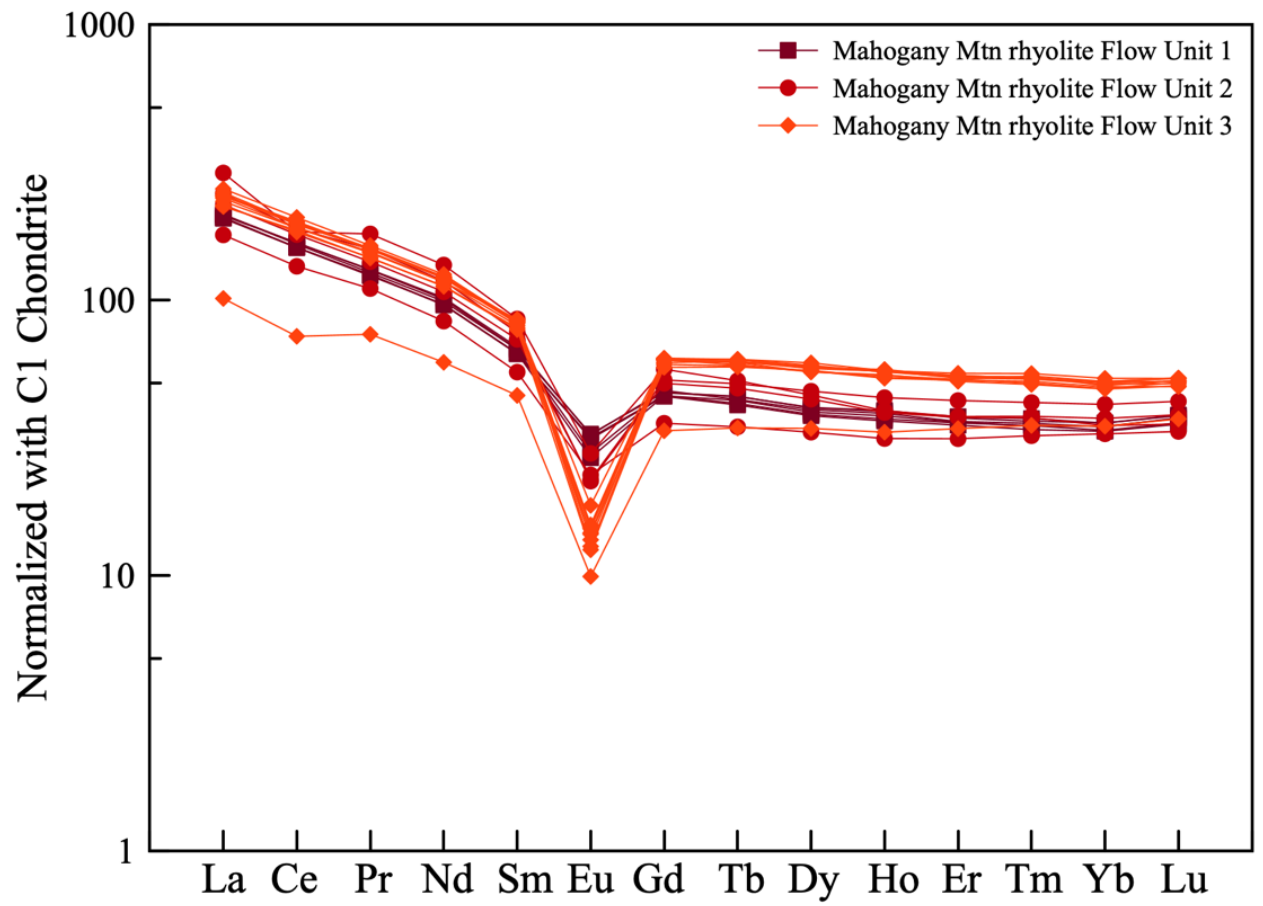

Figure 34. Rare earth element diagram for samples of the Mahogany Mountain rhyolite suite normalized to C1 chondrite of McDonough \& Sun (1995). Samples of flow unit 1 are symbolized with burgundy squares, samples of flow unit 2 are symbolized with dark red circles, and samples of flow unit 3 symbolized with red diamonds. 


\subsubsection{The Bannock Ridge Rhyolite}

\section{Field Observations}

The Bannock Ridge rhyolite (BRR) is a porphyritic, crystal-poor rhyolite lava which makes up a lava dome oriented N-S, known as Bannock Ridge (Fig. 11). The lava dome is located just north north-east of Mahogany Mountain. The BRR comprises a single dome approximately $50 \mathrm{~m}$ thick, and covers an area of approximately $13 \mathrm{~km}^{2}$, comprising approximately $1.6 \mathrm{~km}^{3}$ of erupted rhyolite lava.

The BRR lava features platy jointing in devitrified lava exposures and relatively smooth dome topography, resembling lobate-style dome characteristics. However, no discernible lobes were observed along the dome, and may have been covered by colluvium. The unit features glassy and devitrified facies. Glassy facies are dense, dark grey to black in color, and exhibit perlitic texture. Devitrified facies are dense, with red to light pink flow banding in a light grey to white groundmass. Platy jointing was observed in devitrified outcrops, while glassy facies displayed massive layers. Glassy and devitrified facies contained similar mineral assemblages composed of sparse feldspar phenocrysts approximately 1-2 mm in size. Basal breccias were not observed but may outcrop along the dome.

Along the south western edge of the dome, there is an exposure displaying Bannock Ridge rhyolite overlying beige fine-grained tuffaceous sediments, with a grey glassy vitrophyre underlying the devitrified lava. These tuffaceous sediments are observed to stratigraphically overlie the spatially adjacent intra-caldera tuff of Leslie Gulch to the west. The observed stratigraphic relationship suggests, similarly to what was observed with the MMR, a period of sedimentation following caldera formation, and 
subsequent emplacement of the rhyolite lava, possibly in a wet, lacustrine setting result of OIG development. The orientation and stratigraphic relationship observed at Bannock Ridge rhyolite dome could be indicating the location of either a caldera ring fracture, similar to the neighboring Mahogany Mountain rhyolite (Fig. 11), or N-S trending normal faults of the Devils Gate fault zone. Crustal extension within the graben would provide a path for ascent to the surface, and several normal faults have been mapped along Bannock Ridge as evidence of post-emplacement faulting.

\section{Geochemistry \& Petrography}

The Bannock Ridge rhyolite (BRR) contains approximately 2-3\% phenocrysts, consisting of euhedral and subhedral plagioclase and alkali feldspar, euhedral to

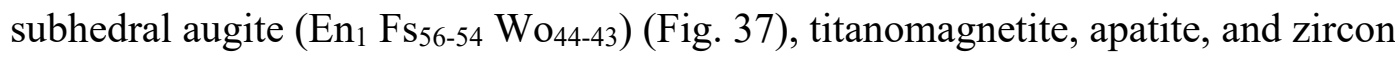
within a vitric or densely devitrified groundmass. Compositions for feldspars of the BRR range from Oligoclase $\left(\mathrm{An}_{20-18} \mathrm{Ab}_{74-71} \mathrm{Or}_{11-9}\right)$ to Anorthoclase $\left(\mathrm{An}_{13-8} \mathrm{Ab}_{71-66} \mathrm{Or}_{26-15}\right)$, and display a transition from more mafic composition e.g., Ca-rich, to more alkali-rich compositions (Fig. 36).

The Bannock Ridge rhyolite is classified as a high-silica rhyolite ( 75 wt. \% $\mathrm{SiO}_{2}$ ). Samples of the Bannock Ridge rhyolite display relatively high concentrations of LILEs $\mathrm{K}, \mathrm{Ba}, \mathrm{Rb}, \mathrm{Pb}$, and $\mathrm{Eu}$. The BRR also displays high concentrations of HFSEs including Th, U, Zr, and Hf, with low concentrations of $\mathrm{Nb}$ and Ta (Fig. 38). We can also observe a shallow europium anomaly in the REE pattern (Fig. 39). 


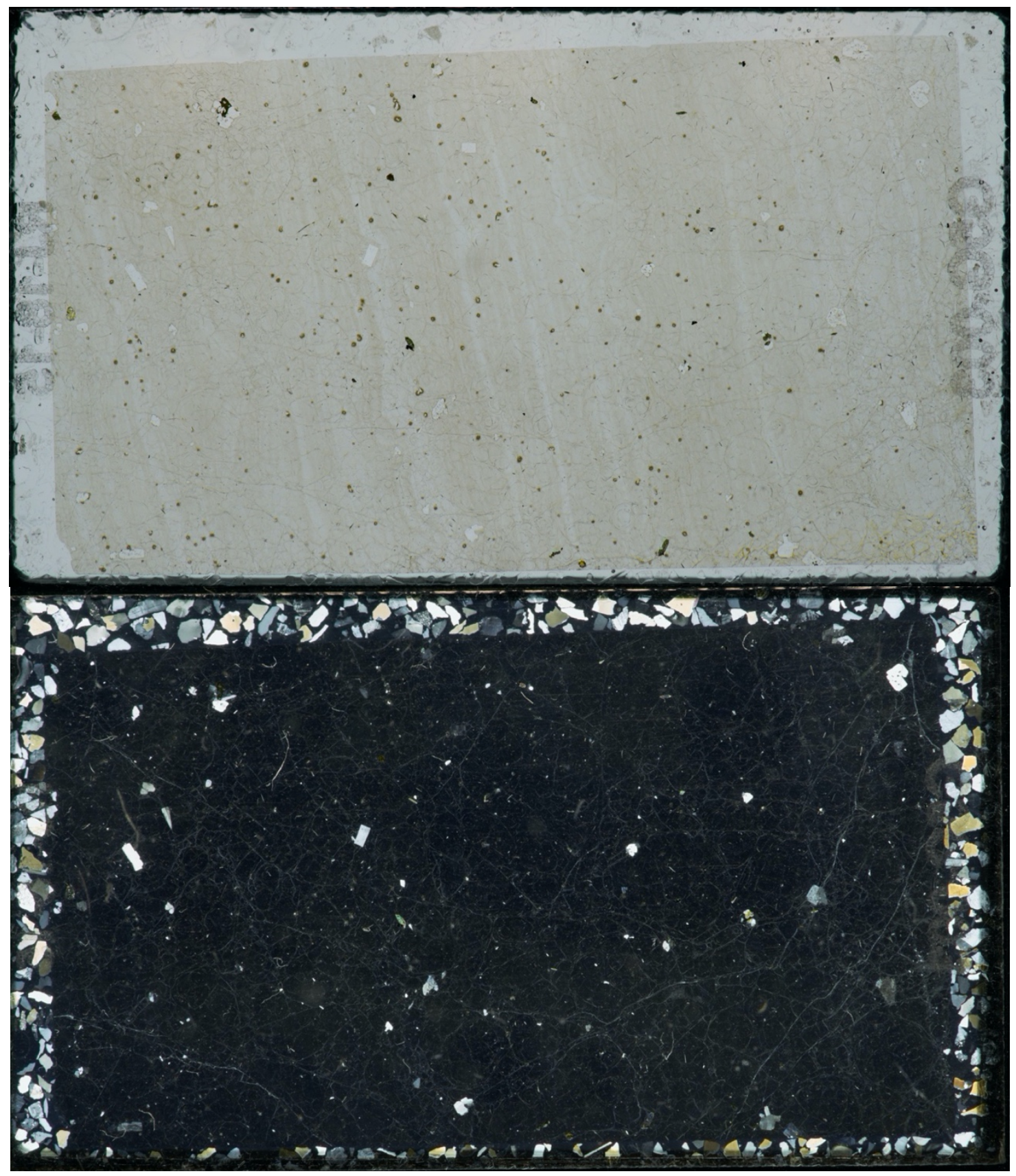

Figure 35. Photomicrographs of sample RJ-18-15 of the Bannock Ridge rhyolite, in thin section. Top image is displayed in plane-polarized light and the bottom image is displayed in crosspolarized light. In view are phenocrysts of sanidine, clinopyroxene, titanomagnetite, and accessory apatite and zircon within a vitrophyric groundmass. 


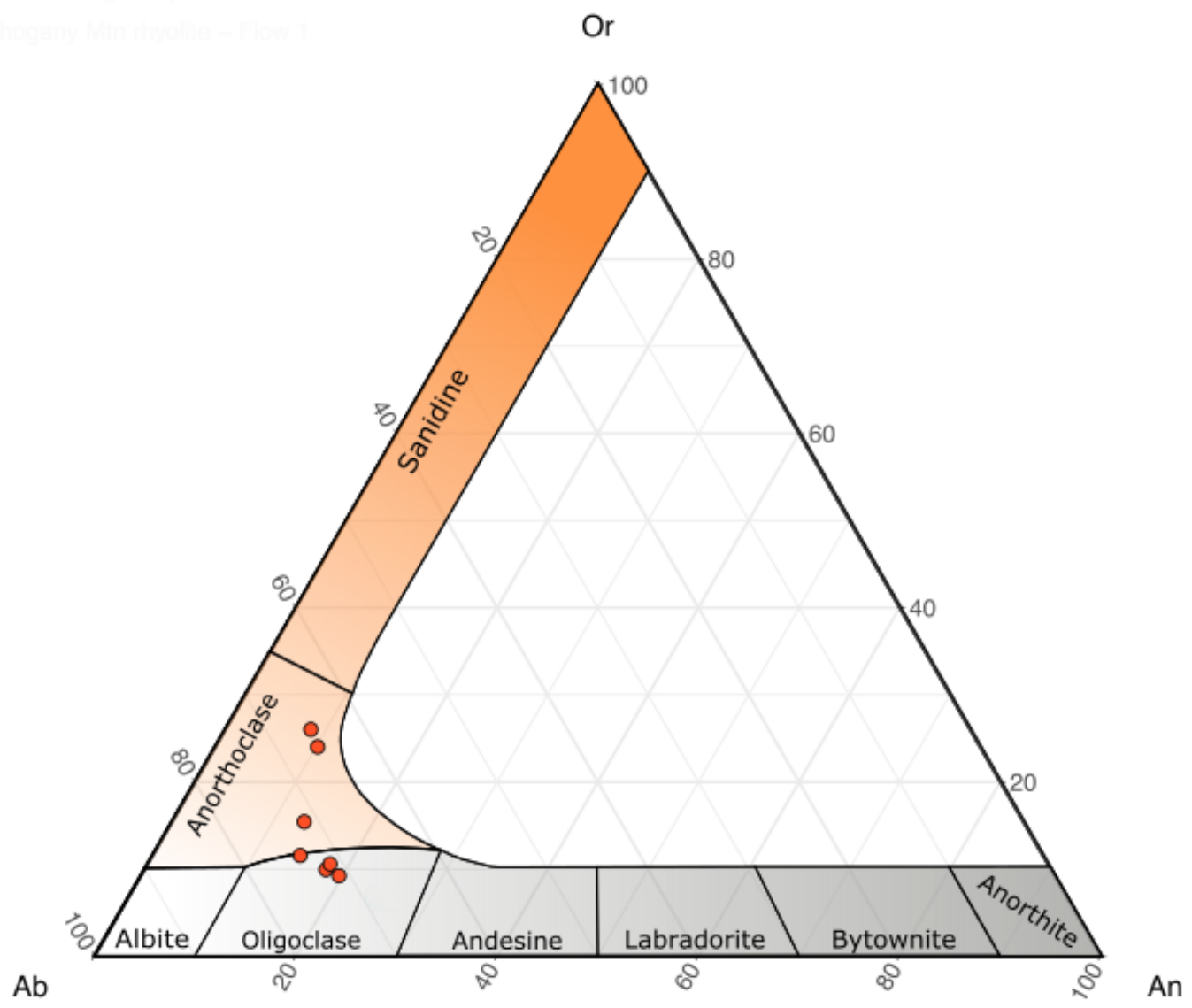

Figure 36. Ternary plot displaying the range of calculated feldspar components from scanning electron microscope data of Bannock Ridge rhyolite feldspar phenocrysts. Feldspars display compositions ranging from Oligoclase (An20-18 $\mathrm{Ab}_{74-71} \mathrm{Or}_{11-9)}$ to Anorthoclase (An $\mathrm{An}_{13-8} \mathrm{Ab}_{71-66} \mathrm{Or}_{26-}$ 15). Bannock Ridge rhyolite samples: RJ-18-02 \& RJ-18-02A.

Table 7. The average, minimum, and maximum calculated feldspar components from scanning electron microscope data of Bannock Ridge rhyolite feldspar phenocrysts. Bannock Ridge rhyolite sample number: RJ-18-02 \& RJ-18-02A.

\begin{tabular}{llll}
\hline \hline RJ-18-02 & \%An & \%Ab & \%Or \\
\hline Max & 18.1 & 73.9 & 15.4 \\
Mean & 24.3 & 72.3 & 12.2 \\
Min & 13.1 & 71.5 & 10.3 \\
RJ-18-02A & & & \\
\hline Max & 19.6 & 71.9 & 26.0 \\
Mean & 19.8 & 68.6 & 15.5 \\
Min & 8.5 & 65.6 & 9.2 \\
\hline
\end{tabular}




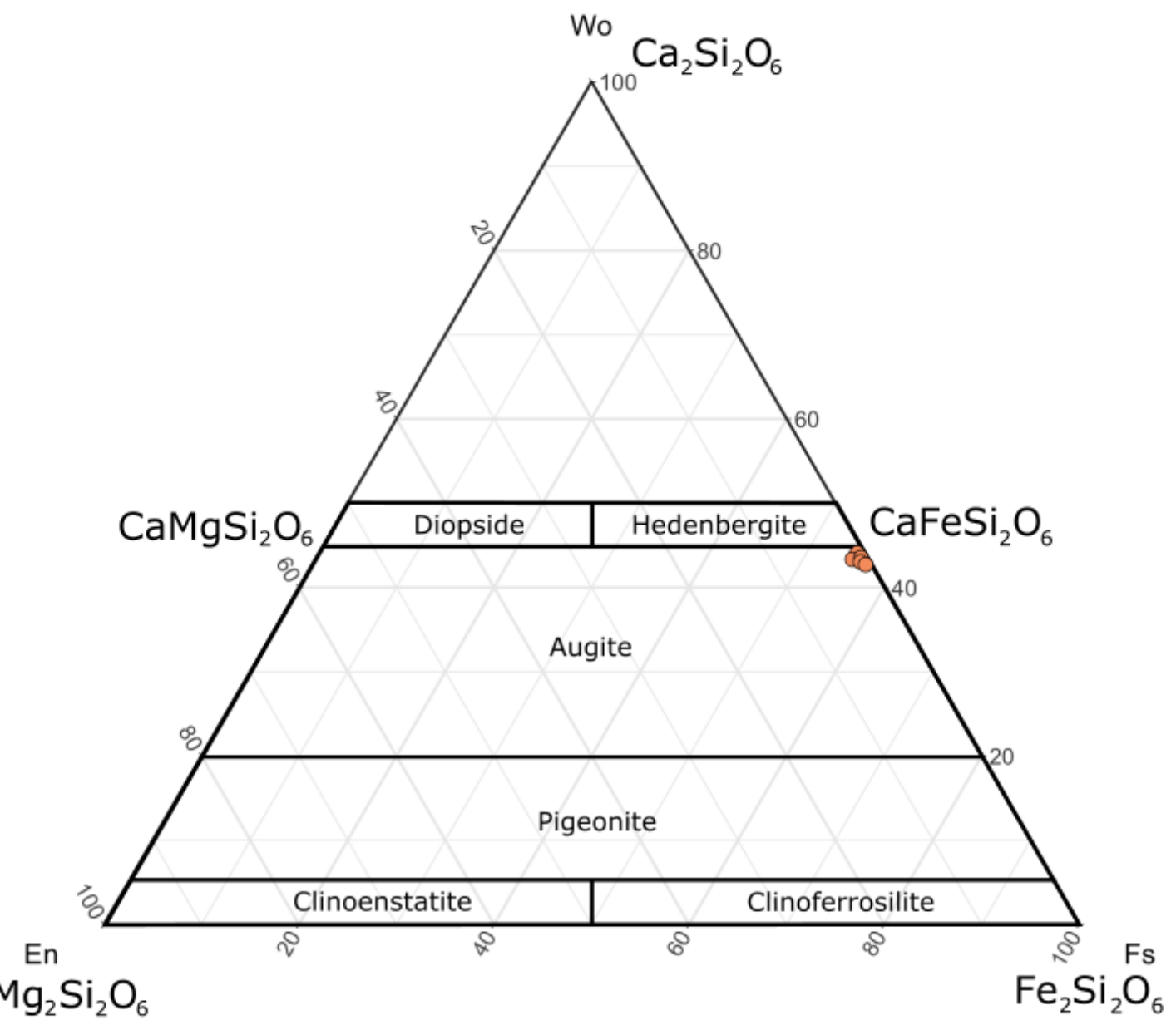

Figure 37. Ternary plot displaying the range of calculated pyroxene components from electron microprobe data of Bannock Ridge rhyolite pyroxene phenocrysts. Pyroxenes are shown in orange, Bannock Ridge rhyolite samples RJ-18-02 \& RJ-18-15.

Table 8. The average, minimum, and maximum calculated pyroxene components from electron microprobe data of Bannock Ridge rhyolite pyroxene phenocrysts. Bannock Ridge rhyolite sample number: RJ-18-15.

\begin{tabular}{llll}
\hline RJ-18-15 & \%En & \%Fs & \%Wo \\
\hline Max & 1.5 & 56.3 & 44.0 \\
Mean & 0.9 & 55.5 & 43.6 \\
Min & 0.6 & 54.9 & 43.0
\end{tabular}




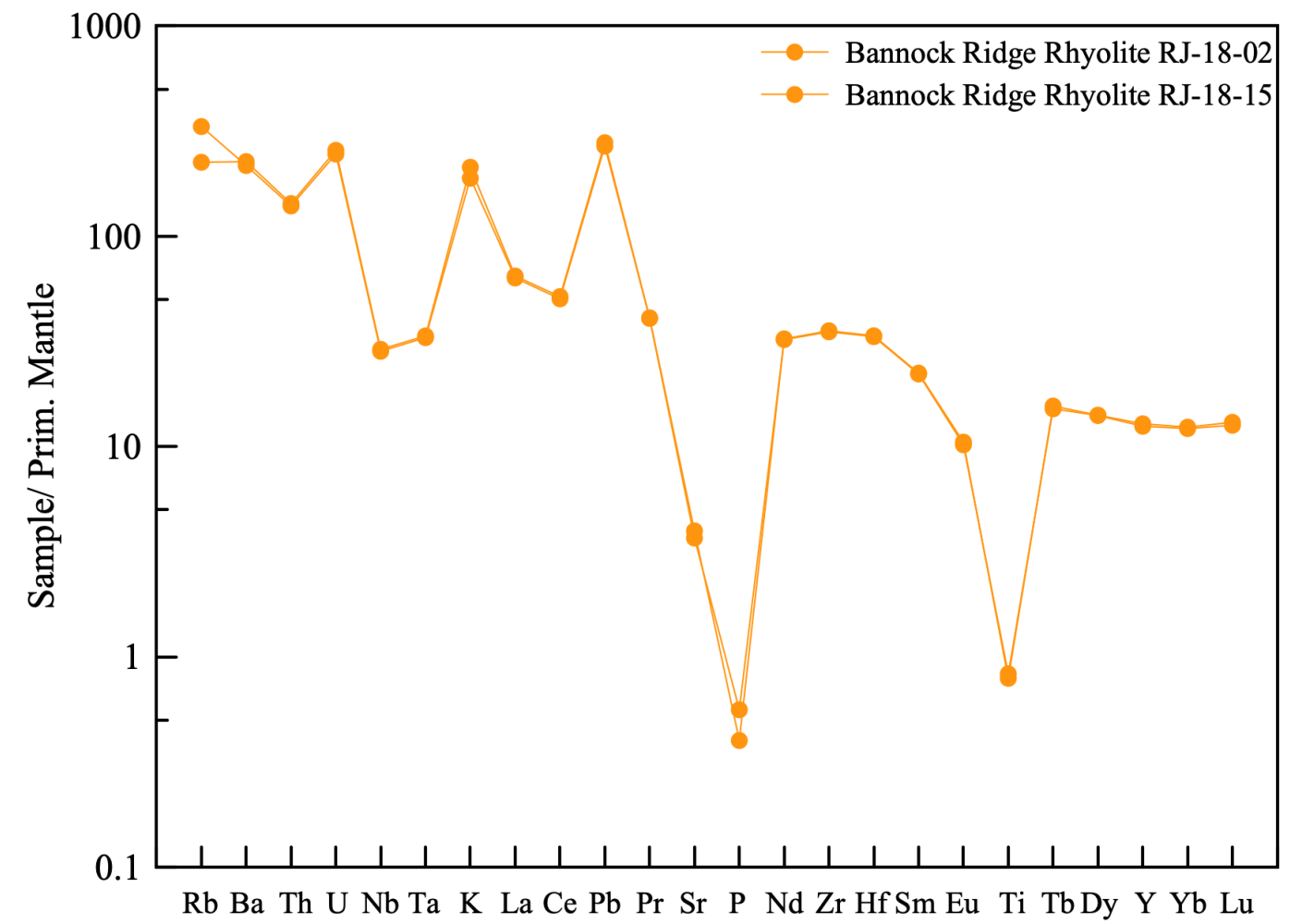

Figure 38. Trace element concentrations of Bannock Ridge rhyolite samples: RJ-18-02 \& RJ-1815. Samples have been normalized to primitive mantle composition, Sun \& McDonough (1989).

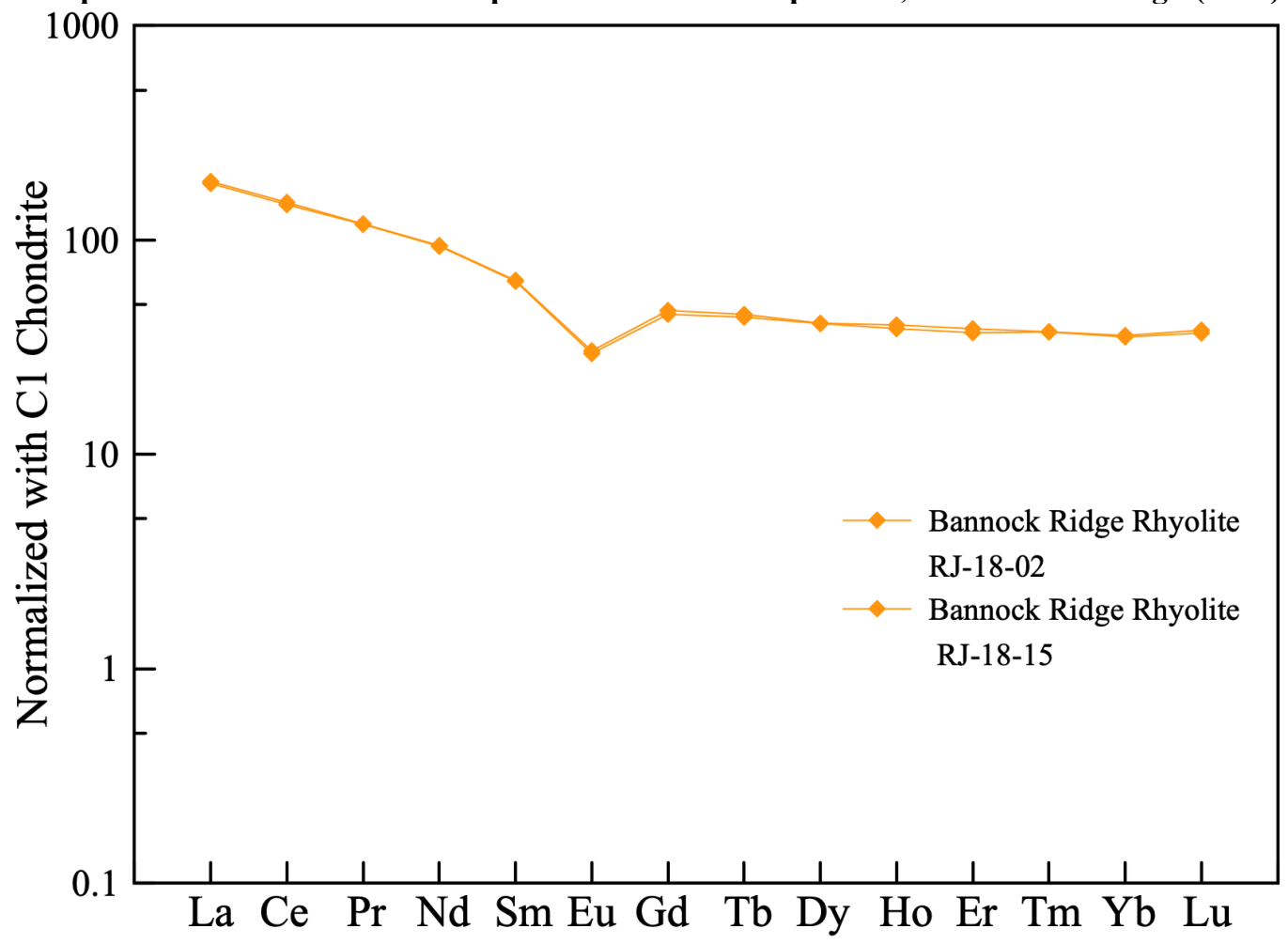

Figure 39. Rare earth element diagram of Bannock Ridge rhyolite samples normalized to $\mathrm{C} 1$ chondrite, McDonough \& Sun (1995). 


\subsubsection{Smith Butte Rhyolite}

\section{Field Observations}

The Smith Butte rhyolite (SBR) is a porphyritic, crystal-poor rhyolite lava making up a relatively small dome on the inferred eastern margin of the caldera (Fig. 11), approximately $1.8 \mathrm{~km}^{2}$ in area and $0.1 \mathrm{~km}^{3}$ in volume.

Smith Butte rhyolite lithology features massive or platy-jointed, incipiently devitrified rhyolite. Phenocrysts consist of feldspar and quartz set in a beige devitrified groundmass. Glassy facies may outcrop along the dome but were not observed. Stratigraphically, the SBR lava overlies surrounding fine-grained tuffaceous sediments, suggesting emplacement in a post-caldera setting. The position of the Smith Butte rhyolite dome could be indicative of a normal faults of the Devil's Gate Fault zone or indicate the position of a caldera ring fracture activated by caldera subsidence. The former is the more likely scenario given the timing and position of Smith Butte rhyolite eruption within the history of silicic volcanism for the MM-TFrf.

\section{Geochemistry \& Petrography}

The Smith Butte rhyolite is a porphyritic high-silica rhyolite $\left(77\right.$ wt. \% $\left.\mathrm{SiO}_{2}\right)$ lava with approximately 6-8 \% phenocrysts of alkali feldspar and quartz in a beige devitrified groundmass. Glassy facies may exist but were not observed. Feldspars are low-sanidine $\left(\mathrm{An}_{3-1} \mathrm{Ab}_{50-47} \mathrm{Or}_{51-47}\right)$ composition (Fig. 40).

Trace element characteristics include relatively low abundances of LILEs Rb, Ba, and high concentrations of HFSEs $\mathrm{Nb}$ and Ta (Fig. 41). In the REE pattern (Fig. 42) the SBR lava exhibits a strong negative Eu anomaly, signifying substantial feldspar fractionation from the source magma. The feldspar composition and geochemical 
signature suggest the SBR represents an evolved rhyolite lava emplaced during postcaldera volcanism.

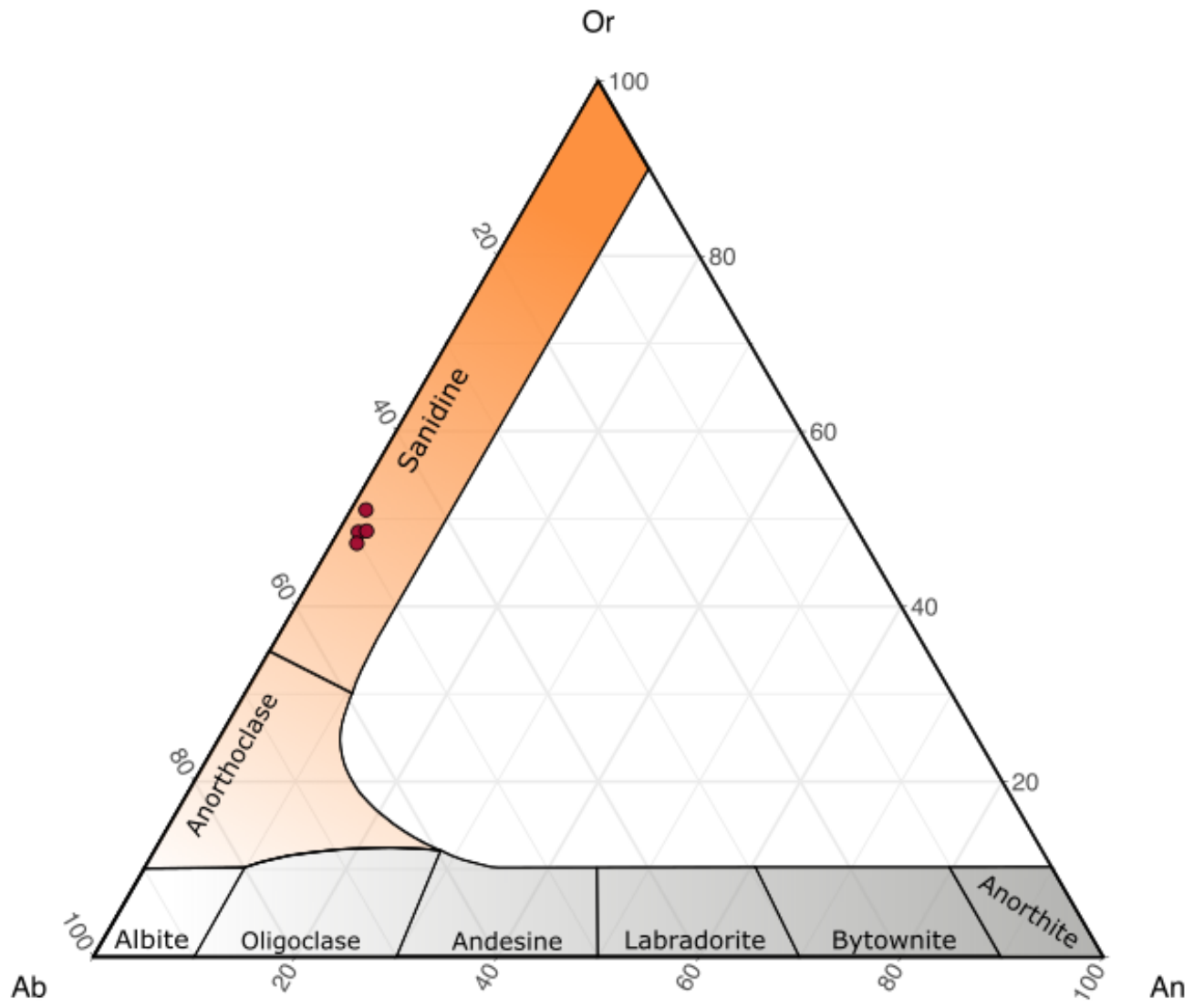

Figure 40. Ternary plot displaying the range of calculated feldspar components from scanning electron microscope data of Smith Butte rhyolite feldspar phenocrysts. Feldspars display sanidine compositions ( $\mathbf{A n}_{3-1} \mathbf{A b}_{50-47} \mathrm{Or}_{51-47)}$. Smith Butte rhyolite sample: RJ-18-04.

Table 9. The average, minimum, and maximum calculated feldspar components from scanning electron microscope data of Smith Butte rhyolite feldspar phenocrysts. Smith Butte rhyolite sample number: RJ-18-04.

\begin{tabular}{llll}
\hline RJ-18-04 & \%An & \%Ab & \%Or \\
\hline Max & 2.7 & 50.3 & 50.9 \\
Mean & 2.1 & 49.0 & 48.8 \\
Min & 1.5 & 47.5 & 47.3 \\
\hline
\end{tabular}




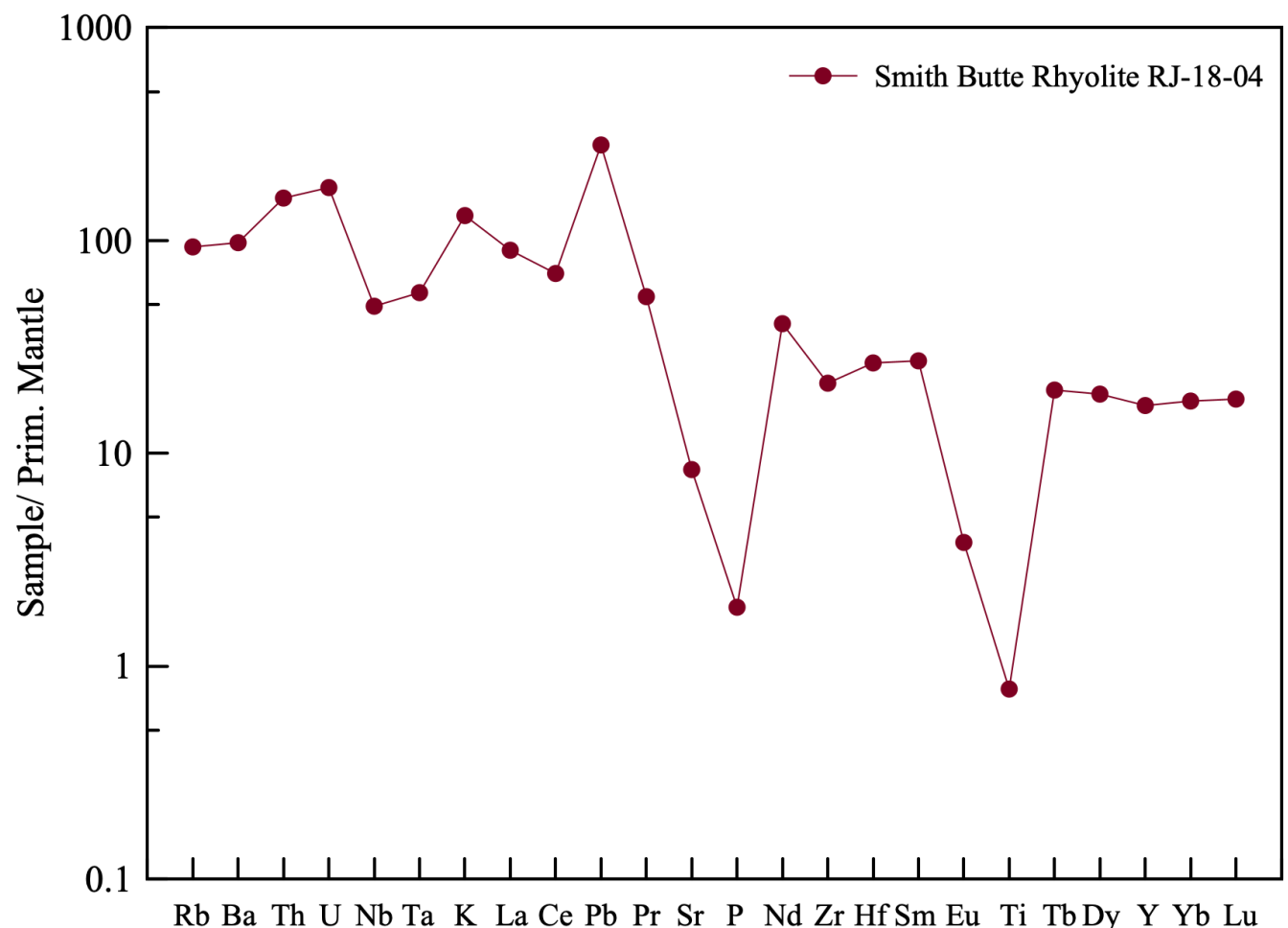

Figure 41. Trace element concentrations of Smith Butte rhyolite sample number: RJ-18-04. Samples were normalized to primitive mantle, Sun \& McDonough (1989).

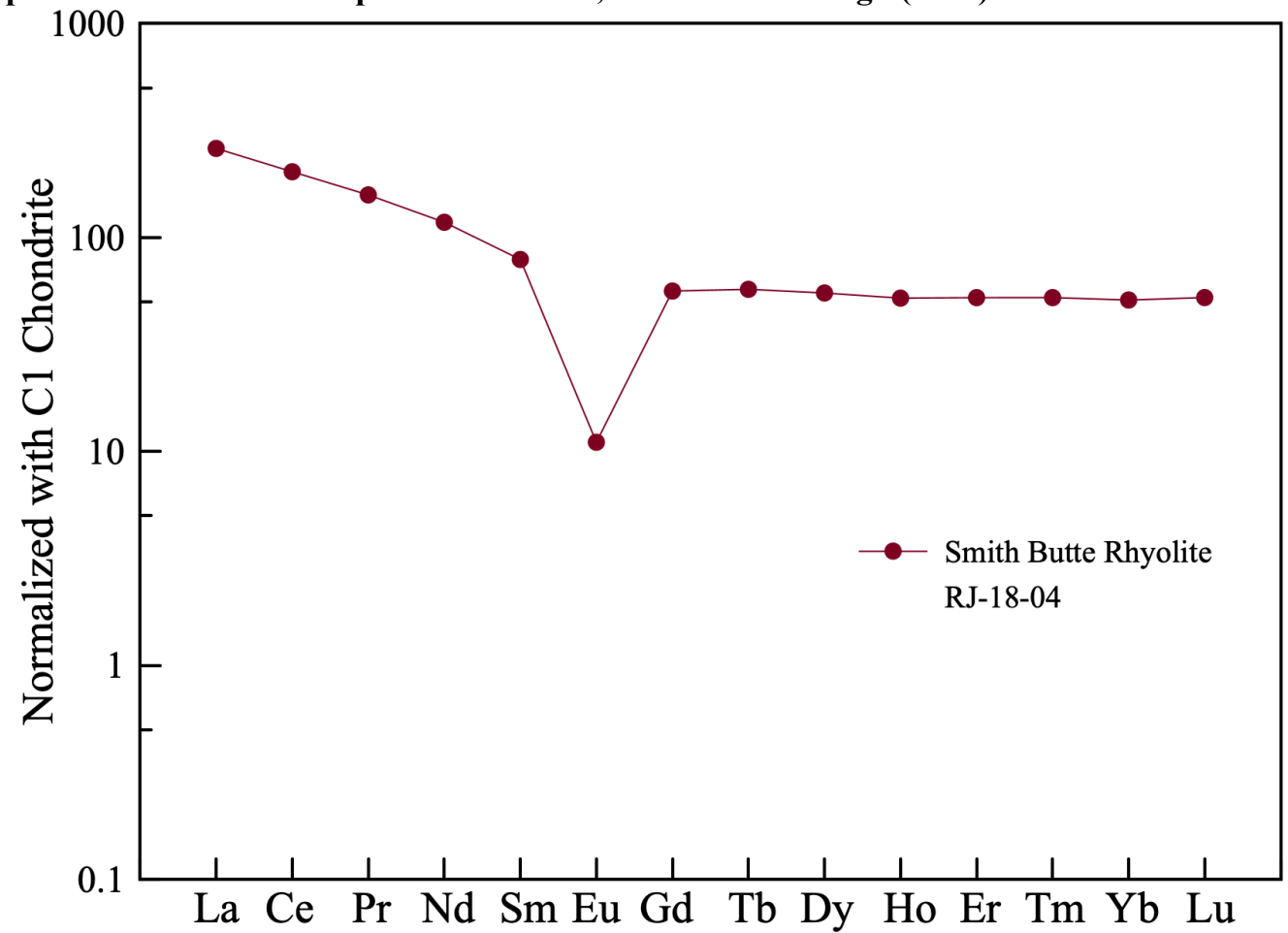

Figure 42. Rare earth element concentrations for Smith Butte rhyolite sample normalized to $\mathrm{C} 1$ chondrite, McDonough \& Sun (1995). Smith Butte rhyolite sample: RJ-18-04. 


\subsubsection{The Birch Creek Rhyolite}

\section{Field Observations}

The Birch Creek rhyolite (BCR) is a porphyritic rhyolite lava making-up several domes located at the southwestern margin of the MMC (Fig. 11), covering an area of approximately $3.8 \mathrm{~km}^{2}$. The Birch Creek rhyolite lava features dense devitrified and dense glassy facies, with similar mineral assemblages. The dense devitrified material is highly resistant to weathering and composes many of the high-standing features of the Birch Creek Historic Ranch area.

Based on field observations, the BCR lava domes exhibit characteristics which align with spiny-type to lobate-type dome features. Several of the domes present exhibit steep sides and can have semi-circular plan views. Additionally, flow lobes can be observed along the margins of flow fronts, marking the extent of the flow lobe prior to weathering and erosion (Fink \& Anderson, 2000).

Stratigraphically, the BCR lava is also observed to be overlying tuffaceous sediments and likely fallout facies of the composite tuff of Leslie Gulch, thought to be locally derived during graben development and successive phreatomagmatic eruptions. The northern most BCR dome was observed to be emplaced adjacent to the southwestern edge of the intra-caldera facies of the composite tuff of Leslie Gulch (Fig. 11). These observations place the BCR's timing of emplacement in the post-caldera stage of development, given sedimentation has taken place prior to emplacement of the rhyolite lava.

The lithology of the Birch Creek rhyolite in outcrop features massive, platyjointed, or columnar-jointed, glassy dark grey vitrophyre and beige devitrified rhyolite. 
Platy jointing is most often observed in devitrified facies, with some occurrences

observed in glassy facies. Columnar jointing was observed at one vitrophyric exposure, featuring columns ranging from $\sim 2-5 \mathrm{~m}$ in length and $\sim 0.5 \mathrm{~m}$ wide, vertically oriented (Fig. 43B). The presence of columnar jointing in exposed cross section of the lava dome is evidence of high temperature emplacement, similar to columnar jointing in basaltic material.

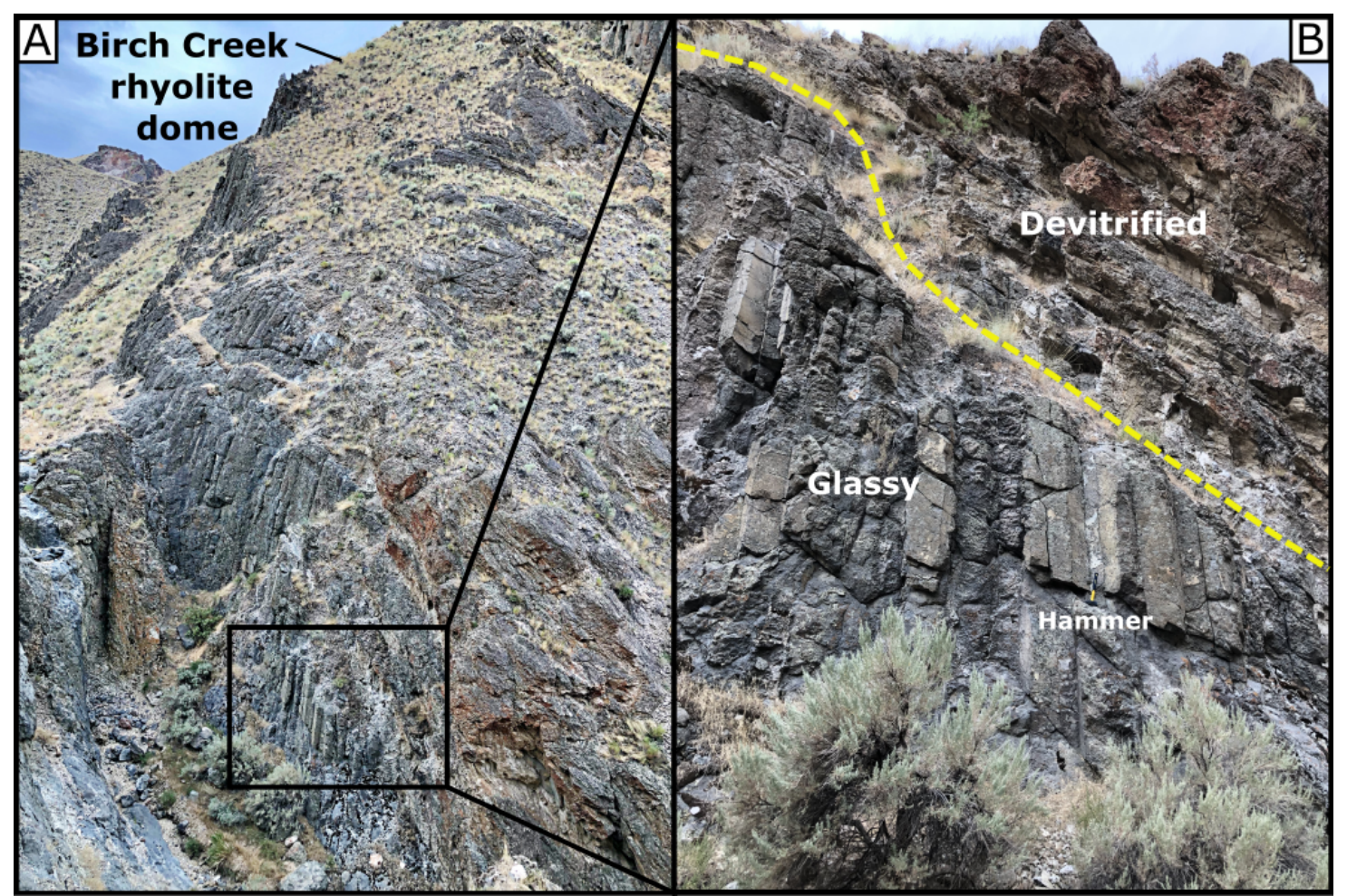

Figure 43. Image $A$ is photograph of the Birch Creek rhyolite lava with glassy rhyolite columns exposed on the extents of a dome. Image B displays lithology of the of the rhyolite lava in crosssectional view.

Groundmass of the dense devitrified material is light grey to beige and features small-scale flow banding evident near the glassy-devitrified transition zone (Fig. 44C). The groundmass of the dense glassy material is dark grey. At one location, a transitional zone between the underlying dense glassy rhyolite and overlying dense devitrified 
rhyolite was observed by successive bands of devitrified material intermingling with the glassy material.

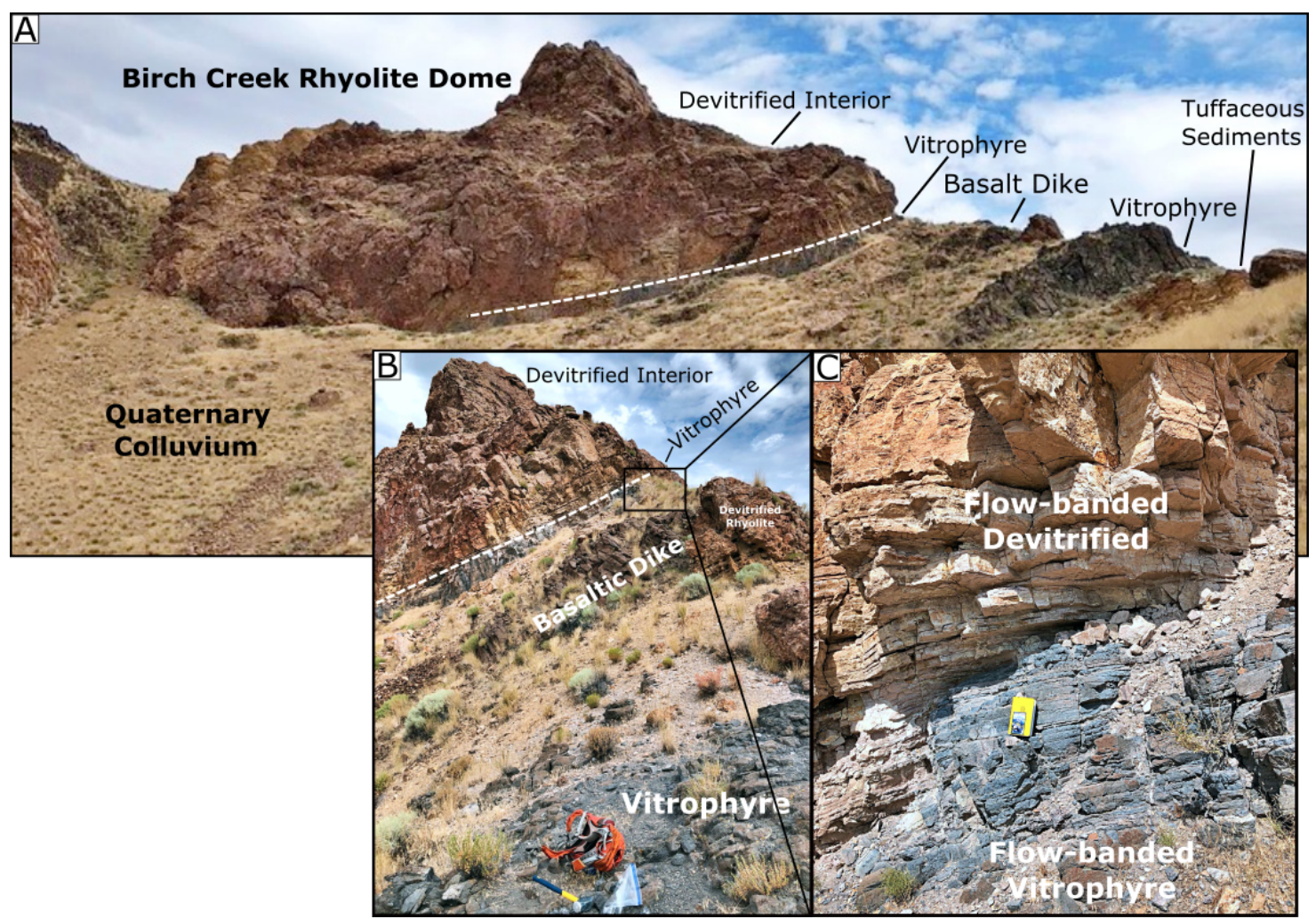

Figure 44. Image A displays view of Birch Creek rhyolite dome with vitrophyre rind exposed. Image $B$ is a closer view of the stratigraphy present along the ridge. Image $C$ gives a view of the glassy-devitrified transition zone, with flow banding observed. Rite-in-the-rain notebook for scale.

\section{Geochemistry \& Petrography}

The Birch Creek rhyolite is a porphyritic low-silica rhyolite lava with approximately $10-12 \%$ phenocrysts. Major mineral phases consisting of euhedralanhedral plagioclase feldspars (Labradorite- Oligoclase), subhedral to anhedral biotite, subhedral to anhedral hornblende, and accessory phases consisting of magnetite and apatite, within a vitric or devitrified groundmass. The BCR is commonly observed to be cumulophyric with glomerocrysts of plagioclase, biotite, hornblende, and magnetite (Fig. 45). 
Plagioclase compositions range from Labradorite $\left(\mathrm{An}_{55} \mathrm{Ab}_{43} \mathrm{Or}_{2}\right)$ to Oligoclase $\left(\mathrm{An}_{28-29} \mathrm{Ab}_{63-64} \mathrm{Or}_{7-8}\right)$ (Fig. 46). Plagioclase phenocrysts exhibit concentric compositional zoning and polysynthetic twinning, with some crystals exhibiting sieve texture. Perlitic cracks are present in the glass, which is evidence of rehydration after emplacement. Secondary quartz is sparsely present and is found crystallized within cracks of the glass. Biotite and hornblende are present composing $\sim 3-4 \%$ by volume.
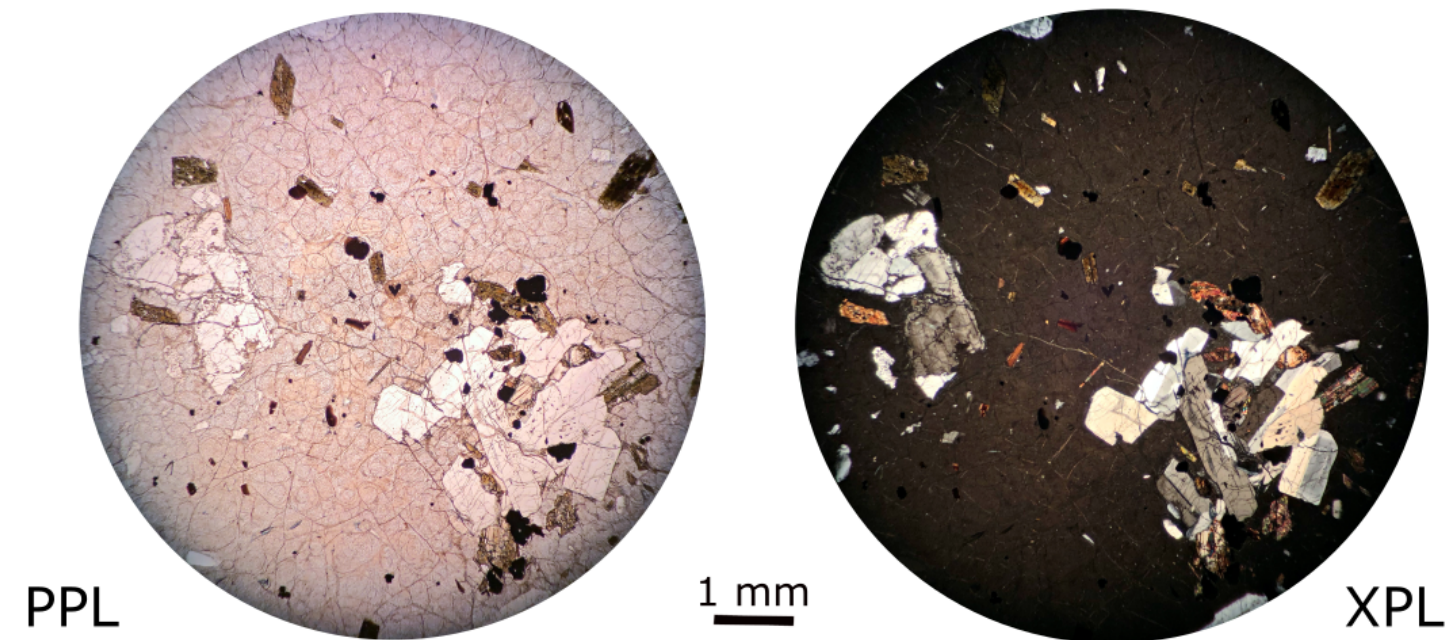

Figure 45. Petrographic images of the Birch Creek rhyolite lava, in plane-polarized light on the left, and cross-polarized light on the right. In view are glomerocrysts of plagioclase, biotite, hornblende, and magnetite.

The Birch Creek rhyolite is classified as a low-silica rhyolite $\left(\sim 72 \mathrm{wt} . \% \mathrm{SiO}_{2}\right)$.

Focusing on major element abundances, the $\mathrm{BCR}$ displays high concentrations of $\mathrm{MgO}$ (0.55 wt. \%), $\mathrm{CaO}\left(1.80\right.$ - 2.03 wt. \%), and $\mathrm{Na}_{2} \mathrm{O}$ (4.65 - 4.83 wt. \%) for rhyolite lavas of this study. In terms of trace elements, the BCR lava displays low concentrations of HFSEs Th, U, Nb, Ta, Zr, and Hf, with relatively high abundances of LILEs Rb, Ba, and Sr (Fig. 47). 


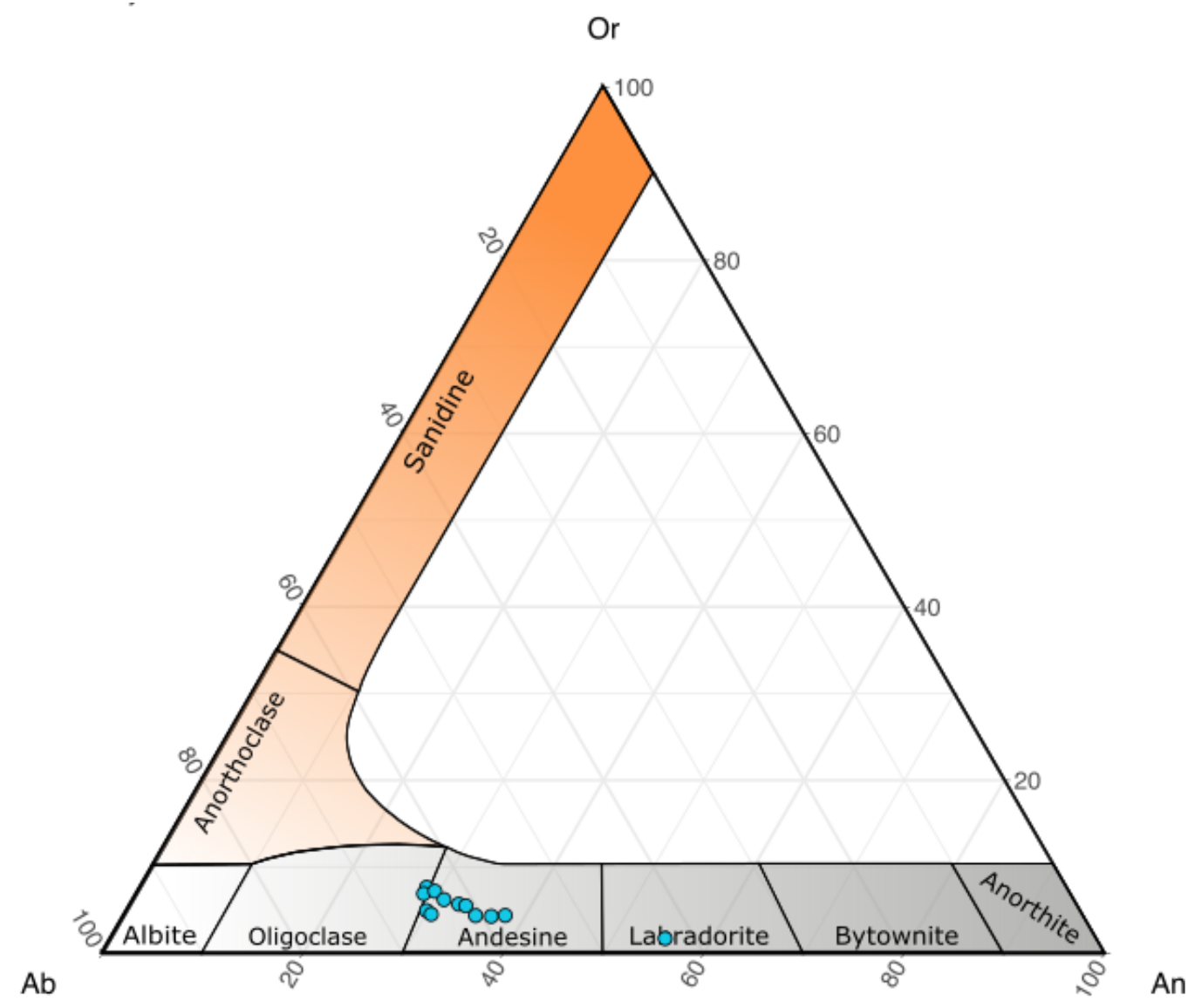

Figure 46. Ternary plot displaying the range of calculated feldspar components from scanning electron microscope data of Birch Creek rhyolite feldspar phenocrysts. Feldspars display compositions ranging from Labradorite ( $\left.\mathrm{An}_{55} \mathrm{Ab}_{43} \mathrm{Or}_{2}\right)$ to Oligoclase compositions (An 28-29 $\mathrm{Ab}_{63-64}$ Or7-8). Birch Creek rhyolite samples: RJ-18-32 \& RJ-18-35.

Table 10. The average, minimum, and maximum calculated feldspar components from scanning electron microscope data of Birch Creek rhyolite feldspar phenocrysts. Birch Creek rhyolite sample number: RJ-18-32 \& RJ-18-35.

\begin{tabular}{llll}
\hline \hline RJ-18-32 & \%An & \%Ab & \%Or \\
\hline Max & 32.7 & 64.5 & 7.6 \\
Mean & 29.9 & 63.3 & 6.7 \\
Min & 28.5 & 61.6 & 5.6 \\
RJ-18-35 & & & 7.2 \\
\hline Max & 55.4 & 65.2 & 4.5 \\
Mean & 34.8 & 59.3 & 1.6 \\
Min & 29.6 & 43.0 & \\
\hline
\end{tabular}




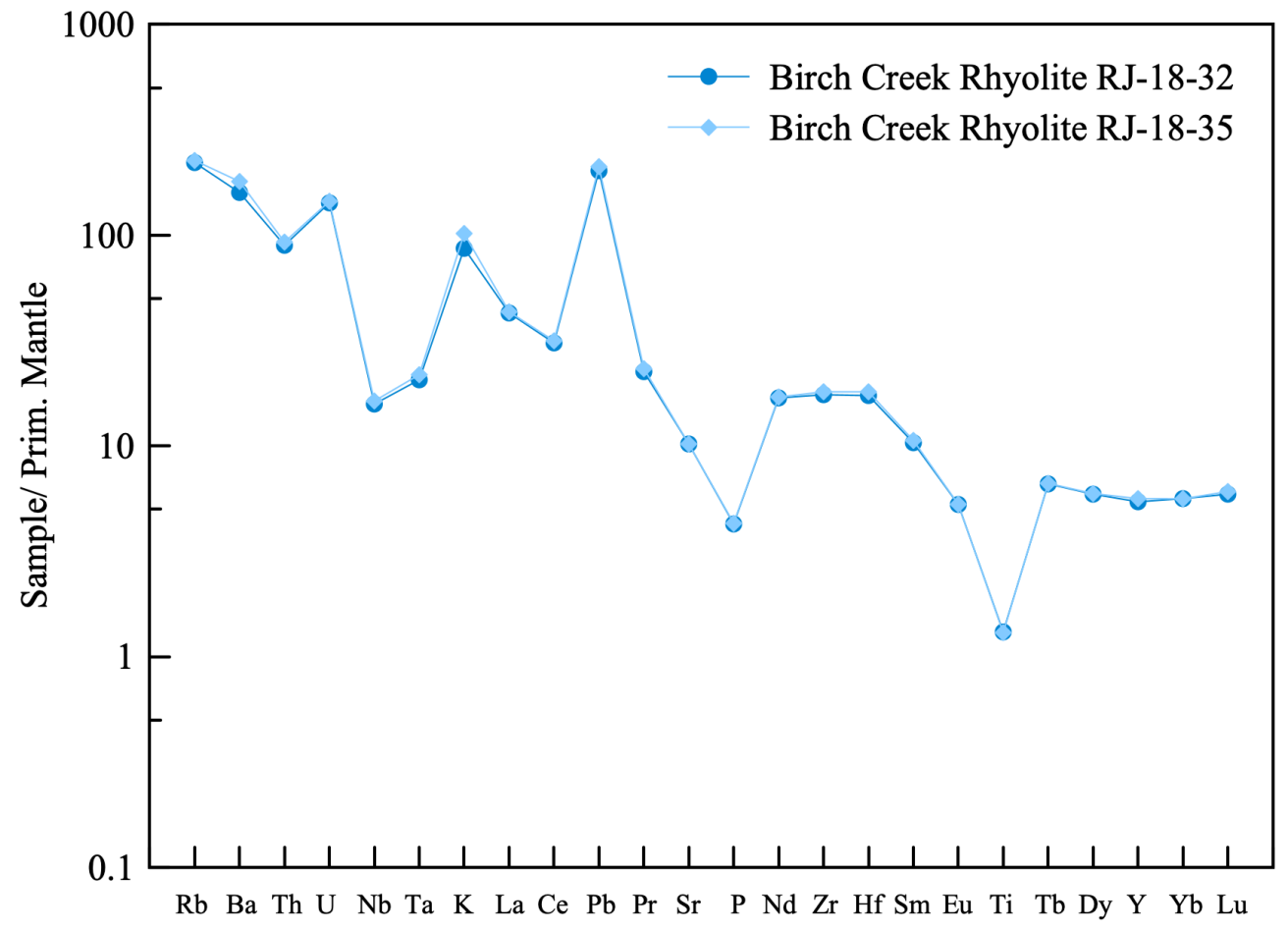

Figure 47. Trace element concentrations of the Birch Creek Rhyolite normalized to primitive mantle composition, Sun \& McDonough (1989). Birch Creek rhyolite samples: RJ-18-32 \& RJ-1835.

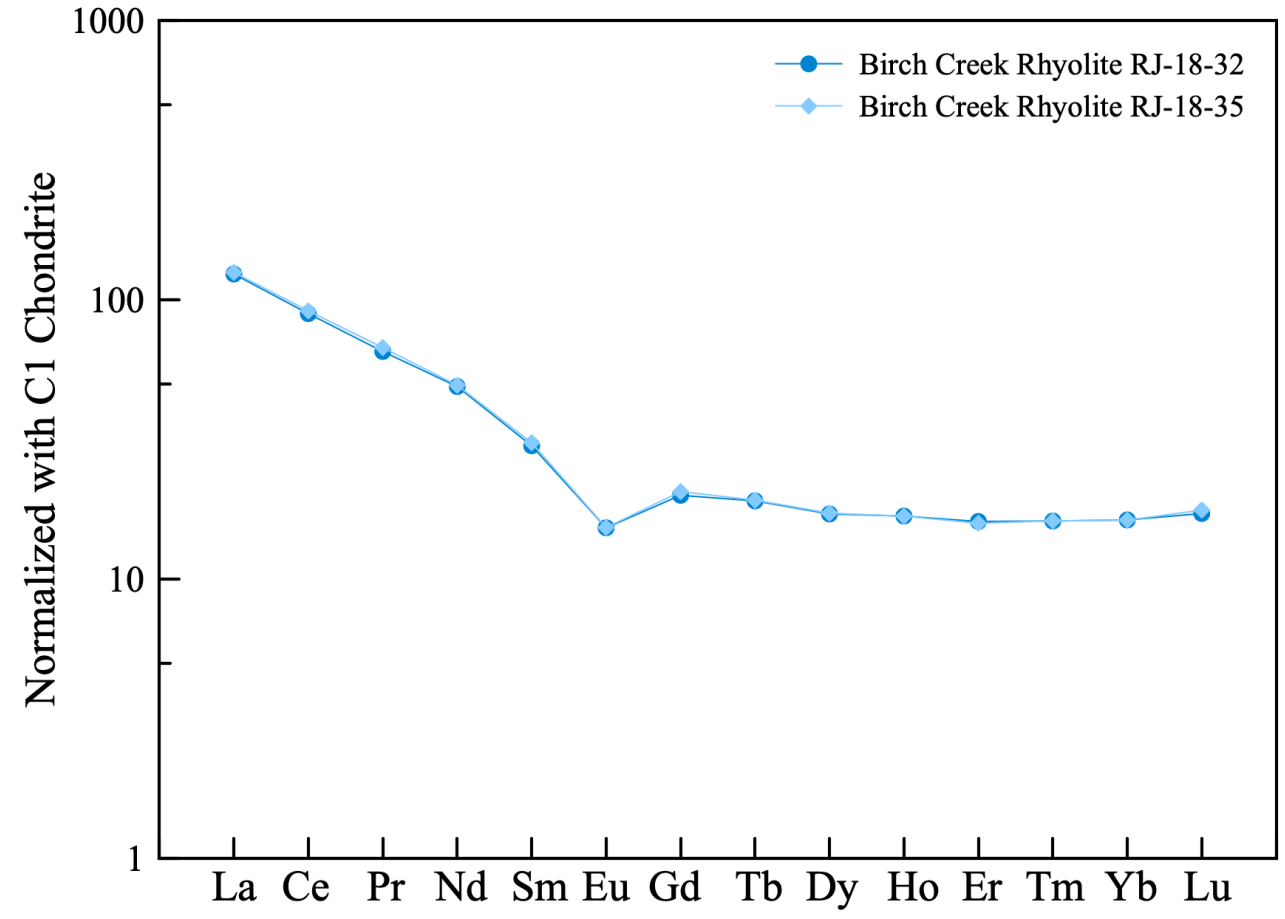

Figure 48. Rare earth element concentrations for Birch Creek rhyolite lava samples, normalized to C1 chondrite, McDonough \& Sun (1995). Birch Creek rhyolite sample numbers: RJ-18-32 \& RJ18-35. 


\subsubsection{The McCain Creek Rhyolite}

\section{Field Observations}

The McCain Creek rhyolite (MCR) is a crystal-rich, porphyritic rhyolite lava that makes up three lava domes on the southwestern and southern flanks of the Mahogany Mountain Caldera, covering an area of approximately $25 \mathrm{~km}^{2}$. The domes are oriented in a crudely northwest trending lineation. The northern most dome, located along the inferred margin of the MMC, was observed to stratigraphically overly the intra-caldera facies of the composite tuff of Leslie Gulch and fine-grained tuffaceous sediments, thought to be deposited following caldera formation and possibly result of graben development.

McCain Creek rhyolite outcrop lithology features massive, glassy black vitrophyre or dark-brown devitrified rhyolite. The glassy facies feature phenocrysts of feldspar, ranging from $\sim 2-7 \mathrm{~mm}$ in size. Glassy groundmass is observed to be black at the most northerly dome and black with red-orange banding in the southern dome. The dense devitrified facies groundmass ranges from dark brown to dark purple.

\section{Geochemistry \& Petrography}

Samples were porphyritic with approximately $18-20 \%$ phenocrysts, commonly cumulophyric (Fig. 49), consisting of subhedral and anhedral sanidine (An5-3 $\mathrm{Ab}_{63-61} \mathrm{Or}_{60-}$ 55), subhedral and anhedral andesine-oligoclase ( $\left.\mathrm{An}_{30-26} \mathrm{Ab}_{63-61} \mathrm{Or}_{11-9}\right)$ (Fig. 50), subhedral and anhedral augite (En30-27 Fs46-31 Wo39-23) and pigeonite (En30 Fs62-61 Wo7-8) (Fig. 51), ilmenite, apatite, and zircon. 

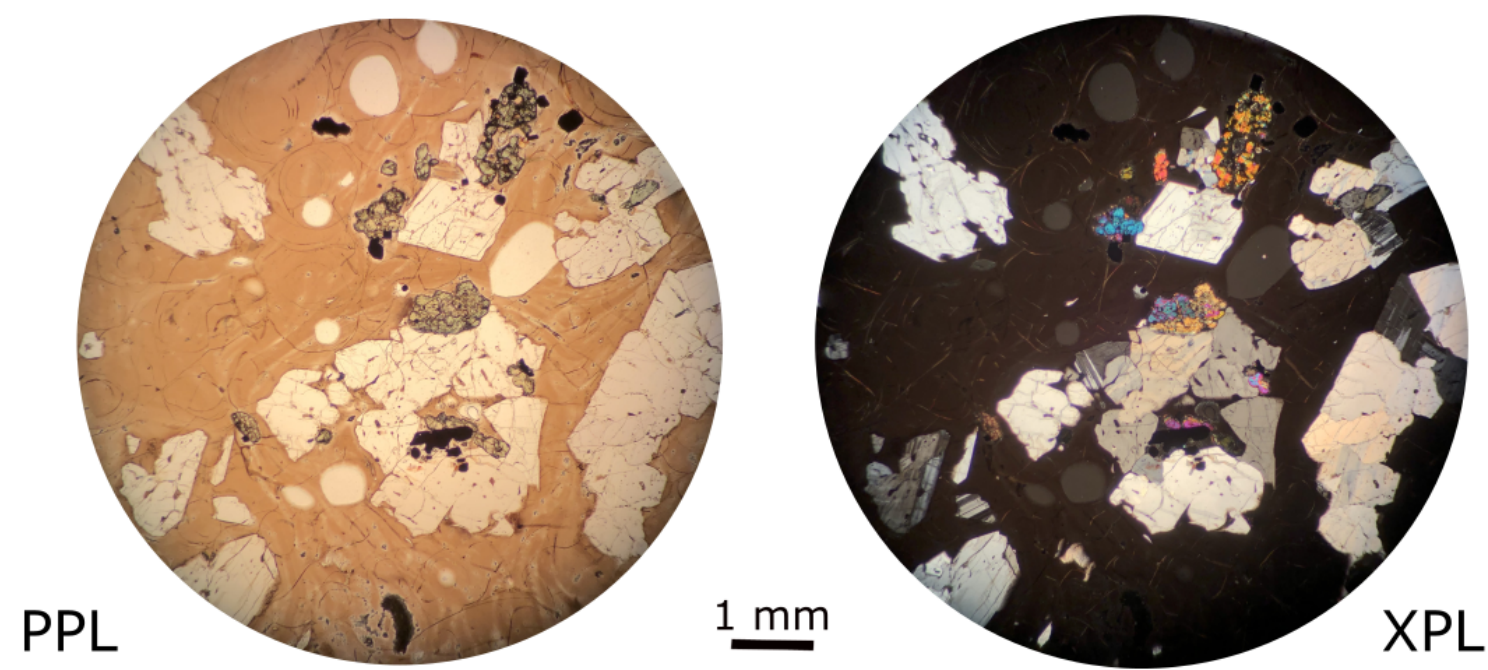

Figure 49. Photomicrographs of sample RJ-18-57 of the McCain Creek rhyolite, in thin section. In view are phenocrysts of Oligoclase, sanidine, clinopyroxene, titanomagnetite, and accessory apatite and zircon within a vitrophyric groundmass.

The McCain Creek rhyolite is a low-silica rhyolite (73 wt. \% $\left.\mathrm{SiO}_{2}\right)$. Focusing on major element abundances, the MCR displays high concentration of $\mathrm{TiO}_{2}(0.45$ wt. \%) and $\mathrm{FeO}^{*}(2.99$ wt. \%) as compared with rhyolites of this study. In terms of trace elements, the unit displays high abundances of HFSEs Th, $\mathrm{U}, \mathrm{Nb}, \mathrm{Ta}, \mathrm{Zr}, \mathrm{Hf}$, and $\mathrm{Ti}$, and LILEs $\mathrm{Rb}, \mathrm{Ba}, \mathrm{Pb}, \mathrm{K}$, and $\mathrm{Eu}$ (Fig. 52). In the REE diagram (Fig. 53), we observe a relatively steep pattern, reflecting an enrichment in LREEs relative to the more compatible heavy rare earth elements. 


\section{McCain Creek Rhyolite Feldspars}

\section{SampleID}

- RJ-18-53

- RJ-18-57

Or

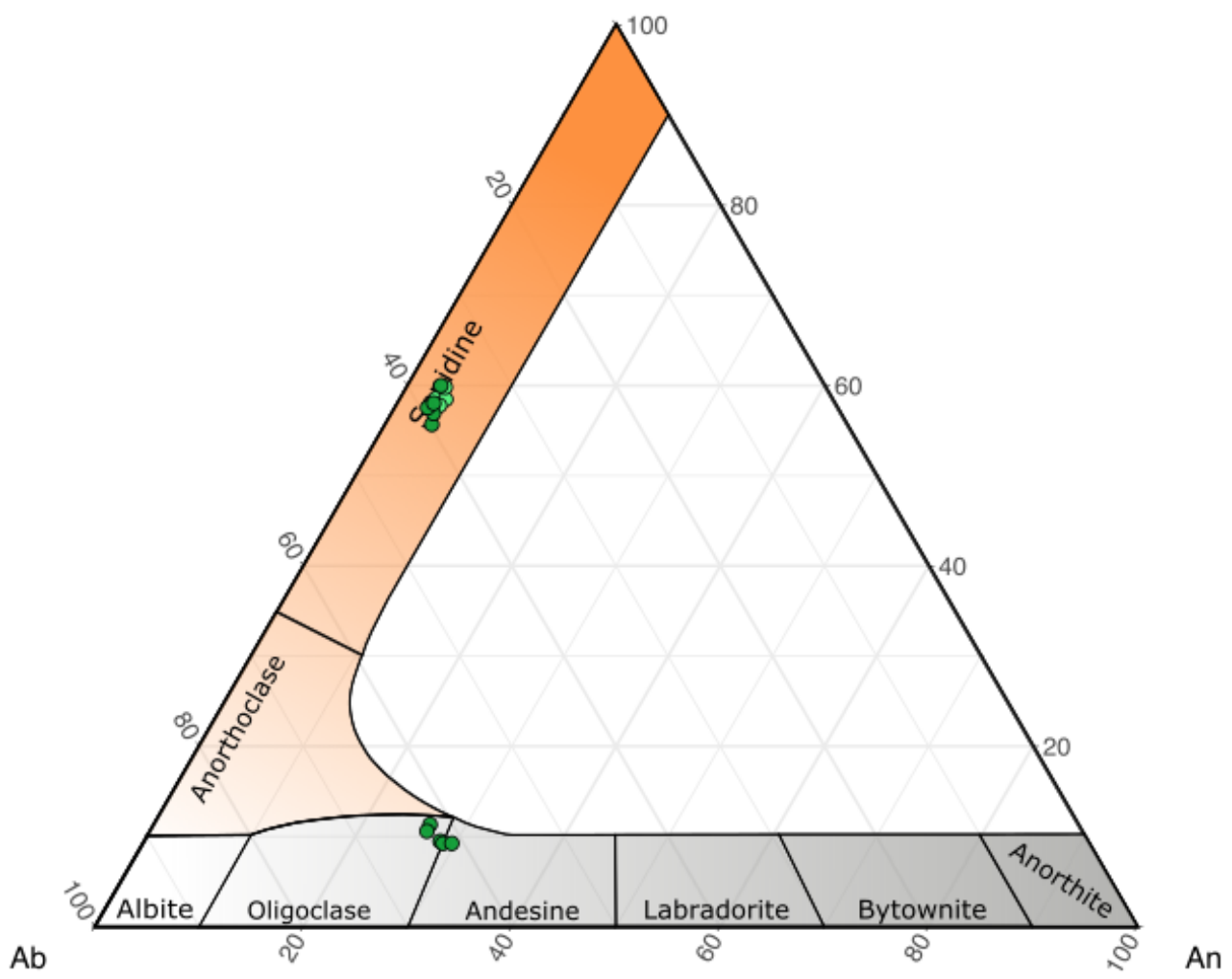

Figure 50. Ternary plot displaying the range of calculated feldspar components from scanning electron microscope data of McCain Creek rhyolite feldspar phenocrysts. Feldspars display compositions ranging from Andesine (An55 $\mathrm{Ab}_{43} \mathrm{Or}_{2}$ ) to Sanidine compositions (An28-29 Ab63-64 Or78). McCain Creek rhyolite samples: RJ-18-53 \& RJ-18-57.

Table 11. The average, minimum, and maximum calculated feldspar components from scanning electron microscope data of McCain Creek rhyolite feldspar phenocrysts. McCain Creek rhyolite sample number: RJ-18-53 \& RJ-18-57.

\begin{tabular}{llll}
\hline RJ-18-53 & \%An & \%Ab & \%Or \\
\hline Max & 4.2 & 38.2 & 59.9 \\
Mean & 3.8 & 37.5 & 58.7 \\
Min & 3.5 & 36.6 & 57.9 \\
RJ-18-57 & & & \\
\hline Max & 29.6 & 62.6 & 60.0 \\
Mean & 8.6 & 46.8 & 27.8 \\
Min & 3.3 & 36.7 & 9.2 \\
\hline
\end{tabular}




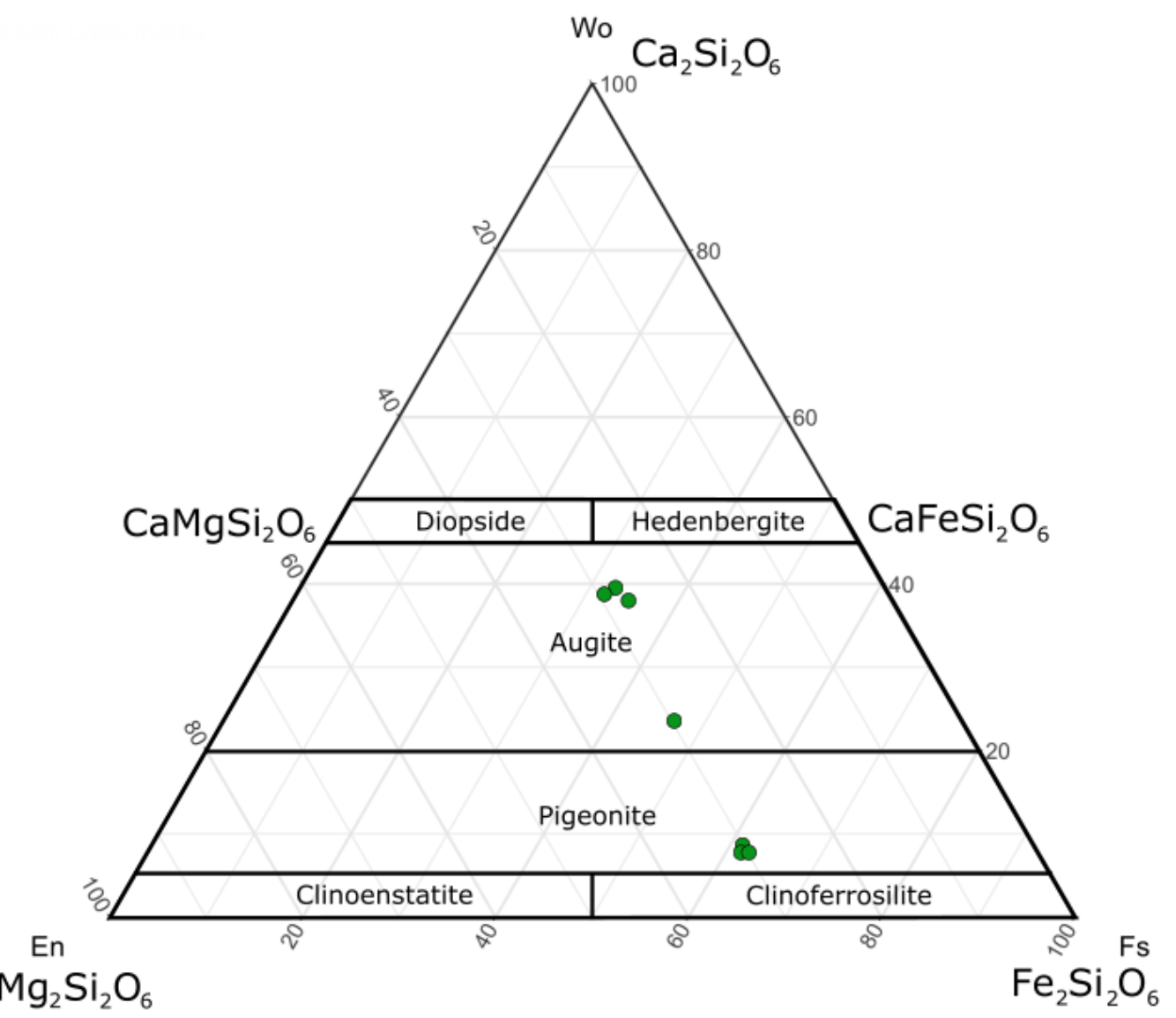

Figure 51. Ternary plot displaying the range of calculated pyroxene components from electron microprobe data of McCain Creek rhyolite pyroxene phenocrysts. Pyroxenes are shown in green, McCain Creek rhyolite sample: RJ-18-57.

Table 12. The average, minimum, and maximum calculated pyroxene components from electron microprobe data of McCain Creek rhyolite pyroxene phenocrysts. McCain Creek rhyolite sample number: RJ-18-57.

\begin{tabular}{llll}
\hline \hline RJ-18-57 & \%En & \%Fs & \%Wo \\
\hline Max & 30.6 & 62.3 & 39.4 \\
Mean & 29.3 & 45.4 & 18.3 \\
Min & 27.3 & 31.8 & 7.7
\end{tabular}




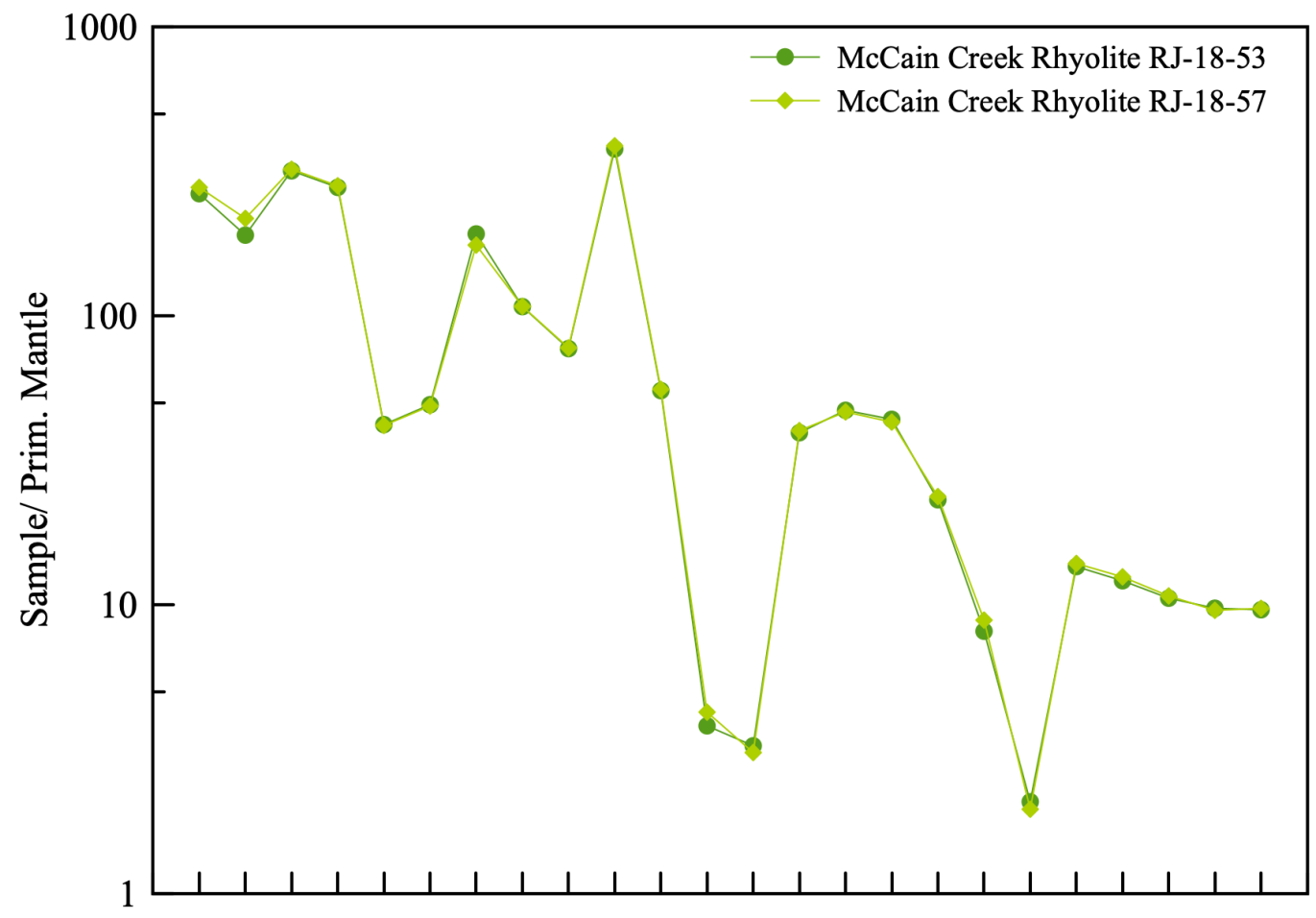

$\mathrm{Rb} \mathrm{Ba}$ Th U Nb Ta K La Ce Pb Pr Sr P Nd Zr Hf Sm Eu Ti Tb Dy Y Yb Lu

Figure 52. Trace element concentrations for McCain Creek rhyolite lavas normalized to primitive mantle, Sun \& McDonough (1989). McCain Creek rhyolite samples: RJ-18-53 \& RJ-18-57.

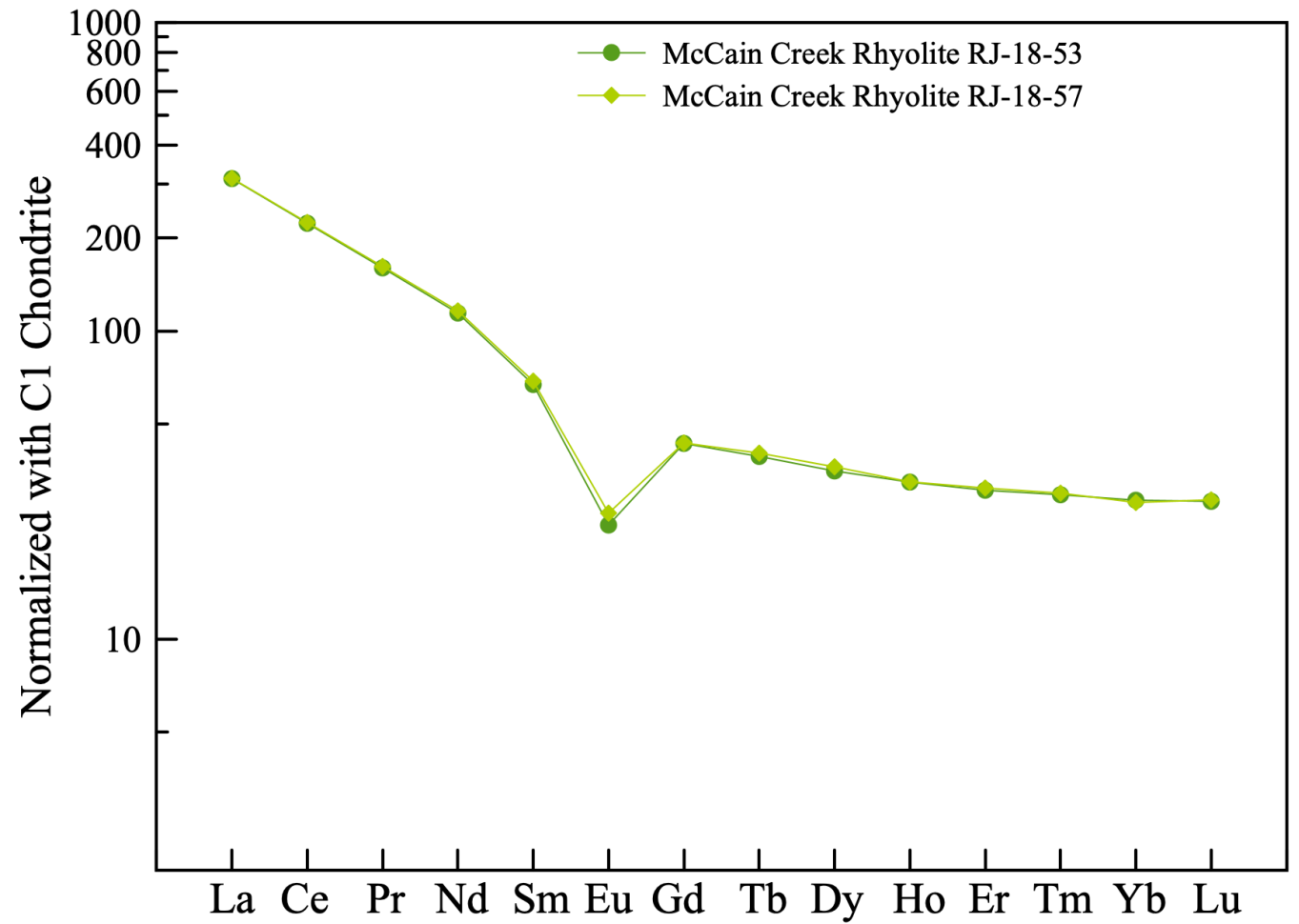

Figure 53. Rare earth element concentrations of McCain Creek rhyolite normalized to C1 chondrite, McDonough \& Sun (1995). McCain Creek rhyolite samples: RJ-18-53 \& RJ-18-57. 


\section{3 $\delta^{18} \mathrm{O}$ Isotope Analysis}

Mineral separates of alkali feldspar, plagioclase, or quartz, where available, were analyzed for $\delta^{18} \mathrm{O}$ stable isotopic composition. Table 13 contains oxygen isotope results for samples of this study and individual mineral separates, these data are plotted in Fig. 54 against known ${ }^{40} \mathrm{Ar} /{ }^{39} \mathrm{Ar}$ ages. $\delta^{18} \mathrm{O}$ isotope values for rhyolites of the MM-TFrf display normal to slightly high $\delta^{18} \mathrm{O}$ values ranging from +5.1 to $+7.1 \%$, with the McCain Creek rhyolite lava displaying a relatively low $\delta^{18} \mathrm{O}$ value $\left(\delta^{18} \mathrm{O}=+3.9 \%\right.$.

Approximate $\delta^{18} \mathrm{O}$ magma compositions were calculated using correction equations formulated by Dr. Ilya Bindeman and others (Eqns. D-2, Bindeman \& Valley, 2002; D-3, Bindeman and Valley, 2003; D-1, Bindeman et al., 2004). After applying the correction, we see the rhyolites of the MM-TFrf exhibit $\delta^{18} \mathrm{O}$ calculated magma values ranging from +5.4 to $+6.9 \%$ ), with the McCain Creek rhyolite lava displaying a relatively low $\delta^{18} \mathrm{O}$ value $\left(\delta^{18} \mathrm{O}_{\text {melt }}=+4.2 \%\right)$. Appendix E contains the complete $\delta^{18} \mathrm{O}$ stable isotope results.

Table 13. Oxygen isotopic compositions acquired from this study. The magmatic $\delta^{18} O$ values were calculated using equations D-1, D-2, and D-3 as detailed in Appendix E.

\begin{tabular}{ccccc}
\hline \hline Unit & Sample ID & Material & $\mathbf{\delta}^{\mathbf{1 8}} \mathbf{O}(\mathbf{\% o})$ & $\begin{array}{c}\text { Calculated } \boldsymbol{\delta}^{\mathbf{1 8}} \mathbf{O} \\
\text { magma (\%o) }\end{array}$ \\
\hline $\begin{array}{c}\text { Rhyolite SE of } \\
\text { Round Mtn' }\end{array}$ & RJ-18-04 & Sanidine & 6.152 & 6.442 \\
$\begin{array}{c}\text { Ash-flow tuff } \\
\text { (cTLG) }\end{array}$ & RJ-18-28 & Quartz & 6.528 & 6.078 \\
$\begin{array}{c}\text { Mahogany Mtn } \\
\text { rhyolite }\end{array}$ & Sanidine & 5.28 & 5.57 \\
$\begin{array}{c}\text { Smith Butte } \\
\text { rhyolite }\end{array}$ & Quartz & 7.135 & 6.685 \\
$\begin{array}{c}\text { Birch Creek } \\
\text { rhyolite }\end{array}$ & RJ-18-50 & Oligoclase & 5.993 & 6.283 \\
$\begin{array}{c}\text { McCain Creek } \\
\text { rhyolite }\end{array}$ & RJ-18-32 & Anorthoclase & 6.635 & 6.925 \\
& RJ-18-57 & Qunidine & 6.023 & 6.267 \\
\hline
\end{tabular}




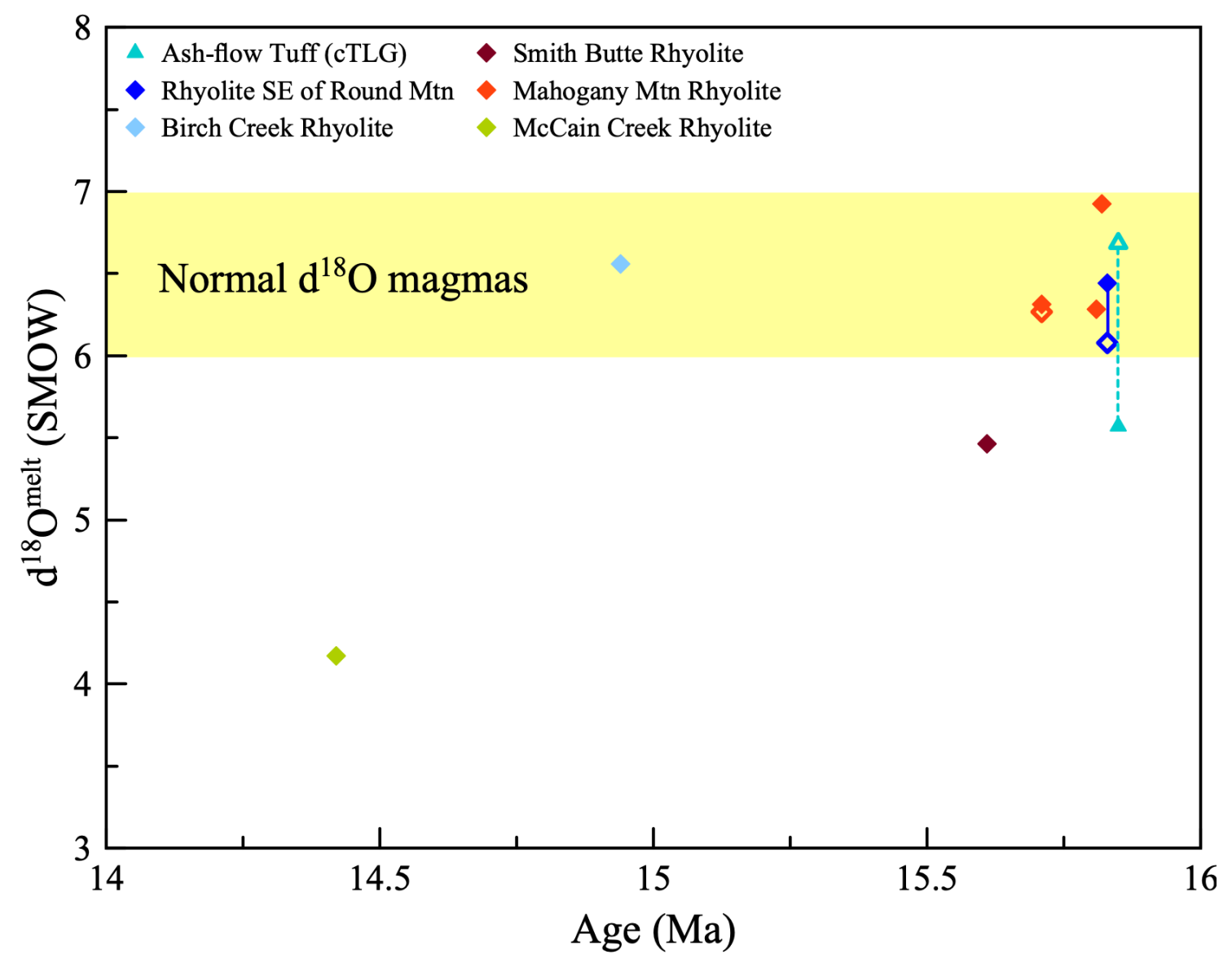

Figure 54. $\delta^{18} \mathrm{O}$ Isotopes for rhyolites of this study, plotted with known age in time. $\delta^{18} \mathrm{O}_{\text {melt }}$ values were calculated using feldspar and quartz phenocryst $\delta^{18} O$ values, shown linked by a dashed or solid line. Feldspars are solid symbols and quartz values are hollow. cTLG, composite tuff of Leslie Gulch. Smith Butte rhyolite age data from Benson \& Mahood (2016). 


\section{CHAPTER 5: DISCUSSION}

\subsection{Inferences of ages for MM-TF rhyolite field}

\subsubsection{Pre-caldera rhyolite lava}

Previously studies of the MM-TFrf have interpreted the "McIntyre Ridge rhyolite" and the Mahogany Mountain rhyolite to be pre-caldera rhyolite lavas, emplaced prior to the eruption of the large-volume, caldera-forming tuff of Leslie Gulch (Ferns, 1993; Benson \& Mahood, 2016). However, ${ }^{40} \mathrm{Ar} /{ }^{39} \mathrm{Ar}$ ages of this study and of Hess (2014) find that the McIntyre rhyolite is in fact composed of two geochemically and mineralogically distinct units that also have different eruption ages. Hence, Hess (2014) and Black \& Streck (2021) name these rhyolites the Old McIntyre and Young McIntyre rhyolites, respectively. The Mahogany Mountain rhyolite lavas were also previously considered to be pre-caldera (Vander Meulen, 1989; Rytuba et al., 1991; Ferns, 1993) but this study obtained ${ }^{40} \mathrm{Ar} /{ }^{39} \mathrm{Ar}$ ages placing their timing of eruption to be subsequent to pyroclastic eruptions of the composite tuff of Leslie Gulch, giving them post-caldera stratigraphic positions.

A pre-caldera rhyolite lava was identified and sampled by Streck, yielding an ${ }^{40} \mathrm{Ar} /{ }^{39} \mathrm{Ar}$ age of $16.019 \pm 0.012 \mathrm{Ma}$ (Fig. 55), and was found to be stratigraphically beneath intra-caldera facies of the tuff of Leslie Gulch. Petrographically, the sample appears to be a rhyolite lava with no evidence of pyroclastic origin, and thus interpreted to represent a pre-caldera unit emplaced prior to any of the ignimbrites of the composite tuff of Leslie Gulch (Streck, pers. comm., 2020). 


\subsubsection{The Composite Tuff of Leslie Gulch}

From stratigraphic evidence collected by Black \& Streck (2021), in combination with ${ }^{40} \mathrm{Ar} /{ }^{39} \mathrm{Ar}$ age dates from this study, Streck \& others, Marcy (2013), and Black (2021), we interpret the composite tuff of Leslie Gulch to be composed of a series of pyroclastic flow deposits ranging from ignimbrites, to surges, to fall-out deposits as also suggested by Vander Meulen (1989) which began erupting at 16 Ma (Black, 2021) and continued through approximately 15.8 Ma (Marcy, 2013). Stratigraphic observations along the Succor Creek road, indicate the tuff of Leslie Gulch is directly overlain by the Old McIntyre rhyolite along the Devil's Gate, that erupted $\sim 16 \mathrm{Ma}$ as well, and by the Young McIntyre rhyolite, yielding an age of $15.76 \pm 0.02 \mathrm{Ma}$, just south of the Devil's Gate along the Succor Creek Road (Hess, 2014; Black, 2021). The pyroclastic flow deposits at Succor Creek have yielded the nominal oldest ages of the tuff of Leslie Gulch identified in the MM-TFrf shifting initiation of highly explosive silicic eruptions back approximately 100 thousand years earlier than previously thought. Additionally, this also shifts the initiation of rhyolite volcanism for the MM-TFrf backward to be more temporally overlap with the waning phases of Grande Ronde Basalt volcanism.

Age estimates for the tuff of Leslie Gulch display a range of eruption ages, with the tuff of Leslie Gulch in Leslie Gulch yielding an age of 15.86 $\pm 0.06 \mathrm{Ma}$ and pyroclastic deposits outside the caldera yielding a slightly older age of $15.98 \pm 0.05 \mathrm{Ma}$ (Streck \& McIntosh, in prep.; Black, 2021). Similar results were obtained by Benson \& Mahood (2016) with ages of $15.94 \pm 0.05,15.93 \pm 0.04 \mathrm{Ma}$ (both recalculated with FCT $=28.201 \mathrm{Ma}$ ). In addition, early work found two ignimbrites in Leslie Gulch thought to represent two distinct caldera-forming eruptions occurring spatially and temporally close 
to one another (Vander Meulen, 1989; Rytuba et al., 1991). Benson \& Mahood (2016) interpret the tuff of Leslie Gulch and tuff of Spring Creek to be altered versions of the same ignimbrite and to have be emplaced contemporaneously. Based on the age dates and lithological variation that our research group observe in Leslie Gulch (e.g., Sweeten, 2020; Fig. 54) and that were also documented in part by previous workers (e.g., Vander Meulen, 1989) and along Succor Creek (Black, 2021), we interpret the following. What is called tuff of Leslie Gulch is a complex and composite deposit consisting of several ignimbrites, numerous surges and some fallout deposits probably emplaced over a significant time span of thousands of years as is also evidenced by the eruptive stratigraphy along Succor Creek (Black, 2021) and interbeds of surge deposits in Leslie Gulch (Sweeten, 2020). The eruption of this composite tuff of Leslie Gulch was closely followed by post-caldera rhyolites which will be discussed later in this section (Table 14) (Fig. 55). The single caldera model of Benson and Mahood (2016) may indeed apply but it was not a single ignimbrite eruption, and the caldera may actually be smaller than proposed by Benson \& Mahood (2016). The thick intra-caldera facies of the cTLG are more restricted spatially than the proposed caldera margins (Fig. 11) and with the lack of an outflow sheet, we interpret this to indicate a smaller caldera size and also smaller eruptive volume for the composite tuff of Leslie Gulch than that proposed by Benson \& Mahood (2016).

The complexity of the explosive stratigraphy within the caldera is highlighted by the discovery of several meter thick, but relatively thin tuff, stratigraphically below a lava belonging to the Three Fingers rhyolite just north of Leslie Gulch. This thin ( $\sim \mathrm{m}$ thick) tuff was identified by Streck and yielded an ${ }^{40} \mathrm{Ar} /{ }^{39} \mathrm{Ar}$ age of $15.95 \pm 0.009 \mathrm{Ma}$. The tuff 
is geochemically distinct from samples of Leslie Gulch tuff indicating explosive eruptions from the MM-TFrf happened elsewhere (like in the northern part of the field known before as the Honeycomb volcanic center). This suggests that this ignimbrite erupted more or less contemporaneously, to the eruptions forming the tuff of Leslie Gulch and adds to the abundance rhyolitic volcanism for the system.

A later ignimbrite eruption for the MM-TFrf as a whole, is represented by the newly identified, post-caldera tuff of Succor Creek, yielding an ${ }^{40} \mathrm{Ar} /{ }^{39} \mathrm{Ar}$ age of $15.74 \pm$ $0.08 \mathrm{Ma}$ (Marcy, 2013) and thin, fine grained and nonwelded ignimbrites that top the section along Succor Creek (Black \& Streck, 2021) and that crop out in the Three Fingers Rock area mapped by Marcy (2013). The welded ignimbrites of the tuff of Succor Creek takes place approximately 30k years before the final eruption of the Mahogany Mountain rhyolite, and end of rhyolite volcanism for the MM-TFrf.

Table 14. ${ }^{40} \mathrm{Ar} /{ }^{39} \mathrm{Ar}$ age data for rhyolites of the Mahogany Mountain-Three Fingers rhyolite field. Age data presented consists of ${ }^{1}$ : samples of this study, ${ }^{2}:$ Streck \& others., ${ }^{3}$ : Swenton (unpub.), ${ }^{4}$ : Marcy (2013), ${ }^{5}$ : Hess, (2014), ${ }^{6}$ : Benson \& Mahood (2016), ${ }^{7}$ : Black (2021).

\begin{tabular}{|c|c|c|c|c|}
\hline Unit & Sample ID & Method & Age (Ma) & Error $( \pm 2 \sigma)$ \\
\hline Old McIntyre rhyolite $^{7}$ & CB-19-65 & ${ }^{40} \mathrm{Ar} /{ }^{39} \mathrm{Ar}$ & 16.02 & 0.02 \\
\hline 'Glassy rhyolite at base of Leslie Gulch'2 & MS-17-15 & ${ }^{40} \mathrm{Ar} /{ }^{39} \mathrm{Ar}$ & 16.019 & 0.012 \\
\hline Tuff of Leslie Gulch ${ }^{7}$ & CB-18-02 & ${ }^{40} \mathrm{Ar} /{ }^{39} \mathrm{Ar}$ & 15.98 & 0.05 \\
\hline Old McIntyre rhyolite $^{7}$ & CB-19-44 & ${ }^{40} \mathrm{Ar} /{ }^{\beta 9} \mathrm{Ar}$ & 15.95 & 0.03 \\
\hline Old McIntyre rhyolite 5 & EJ-12-12 & ${ }^{40} \mathrm{Ar} /{ }^{39} \mathrm{Ar}$ & 15.94 & 0.16 \\
\hline Tuff below Three Fingers rhyolite ${ }^{2}$ & MS-13-27 & ${ }^{40} \mathrm{Ar} /{ }^{39} \mathrm{Ar}$ & 15.91 & 0.01 \\
\hline $\begin{array}{l}\text { Tuff of Leslie Gulch/ Old McIntyre rhy. } \\
\qquad(?)^{2}\end{array}$ & MS-10-06 & ${ }^{40} \mathrm{Ar} /{ }^{39} \mathrm{Ar}$ & 15.88 & 0.03 \\
\hline Tuff of Leslie Gulch ${ }^{2}$ & MS-12-39B & ${ }^{40} \mathrm{Ar} /{ }^{39} \mathrm{Ar}$ & 15.86 & 0.05 \\
\hline 'Rhyolite SE of Round Mtn'" & RJ-18-05 & ${ }^{40} \mathrm{Ar} /{ }^{39} \mathrm{Ar}$ & 15.83 & 0.03 \\
\hline Mahogany Mtn rhyolite - Flow $1^{1}$ & RJ-18-11 & ${ }^{40} \mathrm{Ar} /{ }^{39} \mathrm{Ar}$ & 15.81 & 0.06 \\
\hline Mahogany Mtn rhyolite - Flow $2^{1}$ & RJ-18-50 & ${ }^{40} \mathrm{Ar} /{ }^{39} \mathrm{Ar}$ & 15.82 & 0.05 \\
\hline Young McIntyre rhyolite ${ }^{5}$ & EJ-12-14 & ${ }^{40} \mathrm{Ar} /{ }^{39} \mathrm{Ar}$ & 15.76 & 0.02 \\
\hline Tuff of Succor Creek² & MS-11-15 & ${ }^{40} \mathrm{Ar} /{ }^{\beta 9} \mathrm{Ar}$ & 15.74 & 0.09 \\
\hline Three Fingers intra-caldera rhyolite ${ }^{4}$ & TF-88A & ${ }^{40} \mathrm{Ar} /{ }^{39} \mathrm{Ar}$ & 15.74 & 0.09 \\
\hline Mahogany Mtn rhyolite - Flow $3^{1}$ & RJ-18-03 & ${ }^{40} \mathrm{Ar} /{ }^{39} \mathrm{Ar}$ & 15.71 & 0.05 \\
\hline Smith Butte rhyolite ${ }^{6}$ & TB-193 & ${ }^{40} \mathrm{Ar} /{ }^{39} \mathrm{Ar}$ & 15.71 & 0.05 \\
\hline Birch Creek rhyolite $^{3}$ & VS19-79 & ${ }^{40} \mathrm{Ar} /{ }^{\beta 9} \mathrm{Ar}$ & 14.94 & 0.2 \\
\hline McCain Creek rhyolite ${ }^{1}$ & RJ-18-57 & ${ }^{40} \mathrm{Ar} /{ }^{39} \mathrm{Ar}$ & 14.42 & 0.04 \\
\hline
\end{tabular}




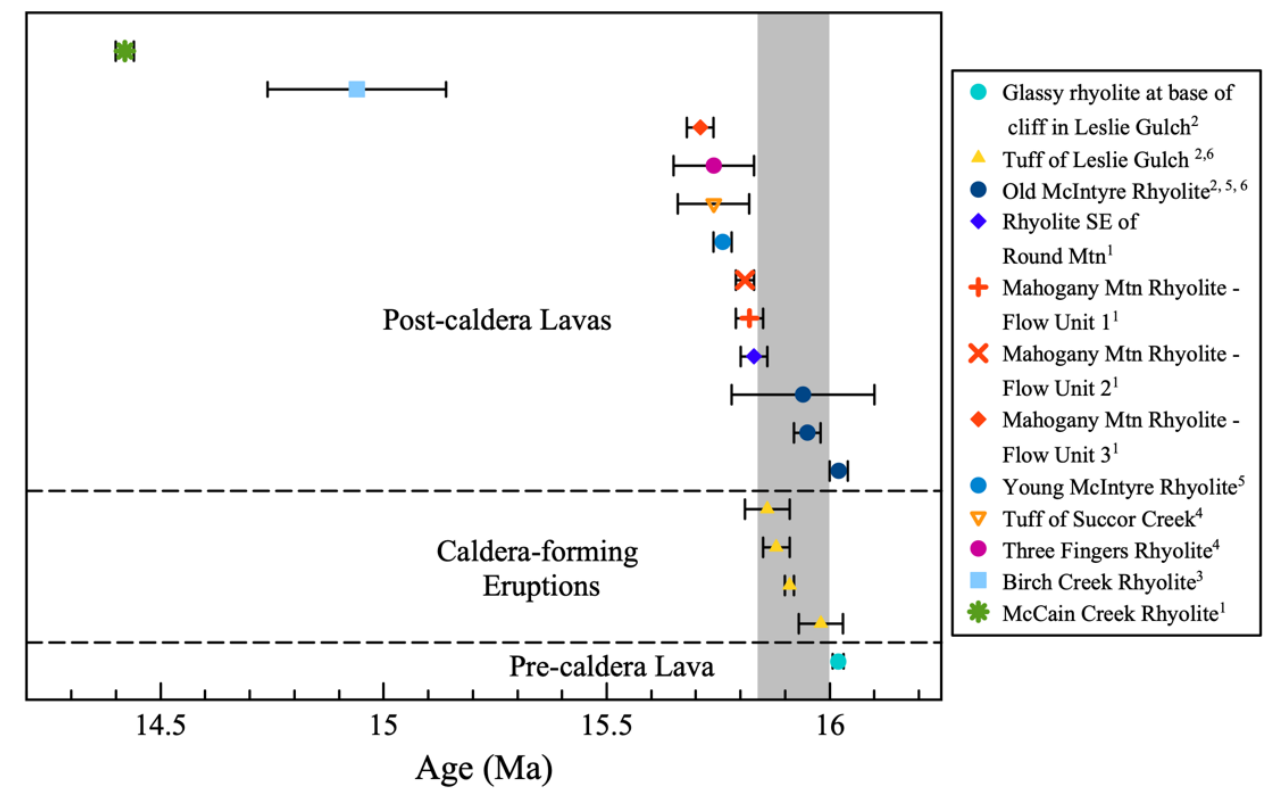

Figure 55. ${ }^{40} \mathrm{Ar} /{ }^{39} \mathrm{Ar}$ age data for rhyolites of the Mahogany Mountain-Three Fingers rhyolite field. Shaded area depicts the extent of ages for samples of the tuff of Leslie Gulch. Age data presented consists of ${ }^{1}$ : samples of this study, ${ }^{2}$ : Streck \& others., ${ }^{3}$ : Swenton (unpub.), ${ }^{4}$ : Marcy (2013), ${ }^{5}$ : Hess, (2014), ${ }^{6}$ : Benson \& Mahood (2016), ${ }^{7}$ : Black (2021).

\subsubsection{Rhyolite SE of Round Mountain}

The 'rhyolite SE of Round Mountain' yielded an ${ }^{40} \mathrm{Ar} /{ }^{39} \mathrm{Ar}$ age of $15.83 \pm 0.04$ Ma, putting the timing of emplacement at the end of caldera formation and following the eruption and emplacement of the composite tuff of Leslie Gulch (Table 14). In the timeline of the volcanism of the MM-TFrf, the 'rhyolite SE of Round Mtn' occurs as the second rhyolite lava to erupt subsequent to formation of the caldera. The position and timing of eruption of this lava could indicate the position of the caldera's eastern ring fracture and been emplaced as result of caldera subsidence (Fig.11). 


\subsubsection{The Mahogany Mountain rhyolite Suite}

Flow units of the Mahogany Mountain rhyolite suite yielded ages displaying an episodic emplacement sequence spanning approximately 15.82-15.71 Ma (Fig. 55). The first two flow units yielded ${ }^{40} \mathrm{Ar} /{ }^{39} \mathrm{Ar}$ ages of $15.81 \pm 0.06 \mathrm{Ma}$ and $15.82 \pm 0.05 \mathrm{Ma}$, which are within error of each other. To better interpret the timing and emplacement sequence for the initial two flow units of the MMR, we combine their respective trace element concentrations with their approximated ages to suggest a quick, but discrete twostage emplacement sequence, where flow unit 1 with the highest concentration of $\mathrm{Ba}$ represents the first pulse of Mahogany Mountain rhyolite magma, followed shortly by MMR flow unit 2 magma with a lower Ba concentration reflecting the earlier geochemical depletion from flow unit 1 . Flow unit 3 of the MMR yielded an ${ }^{40} \mathrm{Ar} /{ }^{39} \mathrm{Ar}$ age of $15.71 \pm 0.05 \mathrm{Ma}$, placing the final flow unit for the MMR long after the first two flow units and also at the end of the silicic volcanism for the MM-TFrf.

With the ${ }^{40} \mathrm{Ar} /{ }^{39} \mathrm{Ar}$ ages acquired from this study, we classify and confirm the Mahogany Mountain rhyolite as a post-caldera rhyolite, as identified by Benson \& Mahood (2016) and in contrast to the interpretations of previous studies (Vander Meulen, 1989; Rytuba et al., 1991), emplaced in a three-stage sequence over a time interval of approximately $110 \mathrm{k}$ years.

\subsubsection{The Bannock Ridge Rhyolite}

The Bannock Ridge rhyolite was not directly dated as a part of this study; however, we interpret the Bannock Ridge rhyolite lava to have erupted contemporaneously with flow unit 1 of the Mahogany Mountain rhyolite $(15.81 \pm 0.06$ 
Ma), due to the strong chemical and petrological similarity between samples of each unit. This age reflects a post-caldera position, erupting relatively early for known post-caldera lavas of the MM-TFrf, possibly via the southeastern caldera ring fracture or a N-S trending normal fault in the caldera floor through resurgence and doming on the eastern half of the caldera.

\subsubsection{The Three Fingers Rhyolite}

Marcy (2013) reported an ${ }^{40} \mathrm{Ar} /{ }^{39} \mathrm{Ar}$ age of $15.74 \pm 0.09 \mathrm{Ma}$ for the intra-caldera Three Fingers rhyolite lava (Fig. 55) (recalculated for FCT $=28.201 \mathrm{Ma}$ ). The estimated timing of eruption is contemporaneous with the eruption of the tuff of Succor Creek, which yielded an ${ }^{40} \mathrm{Ar} /{ }^{39} \mathrm{Ar}$ age of $15.74 \pm 0.08 \mathrm{Ma}$ (Marcy, 2013), previously mapped as the tuff of Spring Creek of Rytuba et al. (1991).

\subsubsection{The Smith Butte Rhyolite}

The Smith Butte Rhyolite was not dated as a part of this study but was dated by Benson \& Mahood (2016), yielding an ${ }^{40} \mathrm{Ar} /{ }^{39} \mathrm{Ar}$ age of $15.71 \pm 0.05 \mathrm{Ma}$ (recalculated for $\mathrm{FCT}=28.201 \mathrm{Ma})$. This age is in agreement with stratigraphic relations observed at Smith Butte and places the Smith Butte rhyolite to be one of the last rhyolite lavas to erupt for mid-Miocene volcanism experienced at the MM-TFrf.

\subsubsection{The Birch Creek Rhyolite}

The Birch Creek rhyolite lava yielded an ${ }^{40} \mathrm{Ar} /{ }^{39} \mathrm{Ar}$ age of $14.94 \pm 0.2 \mathrm{Ma}$ (Fig. 55 , Table 14), erupting approximately 700-800 thousand years after the last rhyolite eruption of the MM-TFrf (Swenton, unpub.). The BCR lava is observed to be emplaced within the Wall Rock Ridge fault zone and along the inferred southwest margin of the 
Mahogany Mountain caldera. Spatially and stratigraphically, the BCR is observed to overlie and intrude tuffaceous sediments and likely air-fall facies of the composite tuff of Leslie Gulch. Given the observed stratigraphic position and ${ }^{40} \mathrm{Ar} /{ }^{39} \mathrm{Ar}$ age of $14.94 \pm 0.2$ Ma, we interpret the BCR to be a post-caldera rhyolite unit, emplaced via faults of the Wall Rock Ridge fault zone or existing caldera ring fractures of the MMC, by a renewed heating event and possibly crustal extension during graben subsidence and development.

The stratigraphic and temporal relationship observed between the BCR and cTLG supports a post-caldera emplacement, in contrast to pre-caldera emplacement interpretations of Benson \& Mahood (2016), with the timing of emplacement occurring approximately 700-800 thousand years after the final rhyolite eruption of the Mahogany Mountain caldera.

\subsubsection{The McCain Creek Rhyolite}

The McCain Creek rhyolite was dated to yield an ${ }^{40} \mathrm{Ar} /{ }^{39} \mathrm{Ar}$ age of $14.42 \pm 0.04$ Ma (Fig. 55, Table 14), placing the timing of eruption long after main phase rhyolite volcanism for the MM-TFrf. The position of the northern most dome of the MCR, lies along the inferred southern margin of the MMC, and within the Dry Creek fault zone (Cummings et al., 2000). With the spatial location and timing of emplacement of the MCR, this could suggest the MCR magma was transported by a combination of normal faults of Dry Creek fault zone and possibly an existing caldera ring fracture, located adjacent to northern most dome (Fig. 11). The timing of the McCain Creek rhyolite eruption is contemporaneous with volcanism of the Western Snake River Plain and could be a distal expression of rhyolite volcanism associated with the Western Snake River 
Plain, as the mantle plume-tail moved farther east toward southern Idaho (Reference). The MCR displays the youngest age of rhyolites of this study, and signifies the last rhyolite eruption prior to emplacement of the Jump Creek rhyolite (11.1 $\pm 0.2 \mathrm{Ma})$ (Armstrong et al., 1980)

\subsection{A-type to I-type affinities \& implications}

Mahogany Mountain - Three Fingers rhyolites can be separated into "A-type" and "I-type" based on the classifications of Whalen et al. (1987) using the relative abundance of $\mathrm{Nb}, \mathrm{Y}, \mathrm{Ta}, \mathrm{Yb}$, and $\mathrm{Rb}$ trace element data. A-type rhyolites are known to have higher $\mathrm{SiO}_{2}$, are rich in $\mathrm{Fe}$ and $\mathrm{Nd}$, and have sums of concentrations of $\mathrm{Zr}, \mathrm{Nb}, \mathrm{Y}$, and Ce above $350 \mathrm{ppm}$ (Fig. 56). A-type rhyolites display higher Ba/Sr ratios, lower $\mathrm{La} / \mathrm{Yb}$ ratios, have higher concentrations of high field strength elements and rare earth elements, and have a high $\mathrm{Fe} / \mathrm{Mg}$ ratio as compared with I-type rhyolites (Whalen et al., 1987). Typical phenocryst phases consist of Fe-rich pyroxene, fayalite, and anorthoclase or Na-rich sanidines. A-type rhyolites are described as originating from "hot and dry" magmas typically associated with bimodal provinces or flood basalt provinces (Whalen et al., 1987; Anderson et al., 2008; Christiansen et al., 2008). Whereas, I-type rhyolites, also known as "calc-alkaline", rhyolites have often lower $\mathrm{SiO}_{2}$, higher concentrations of $\mathrm{MgO}$, $\mathrm{Al}_{2} \mathrm{O}_{3}$, and $\mathrm{Sr}$, and display sums of $\mathrm{Zr}, \mathrm{Nb}, \mathrm{Y}$, and Ce below $350 \mathrm{ppm}$ (Whalen et al., 1987). I-type rhyolites are described as typically crystal-rich, commonly containing hydrous phases, and if they contain pyroxene, it is typically augite or orthopyroxene with lower Fe/Mg ratios. They are described as "cool and wet" magmas, with higher water content, and are often associated with volcanic arcs (Whalen et al., 1987; Christiansen et al., 2008). 


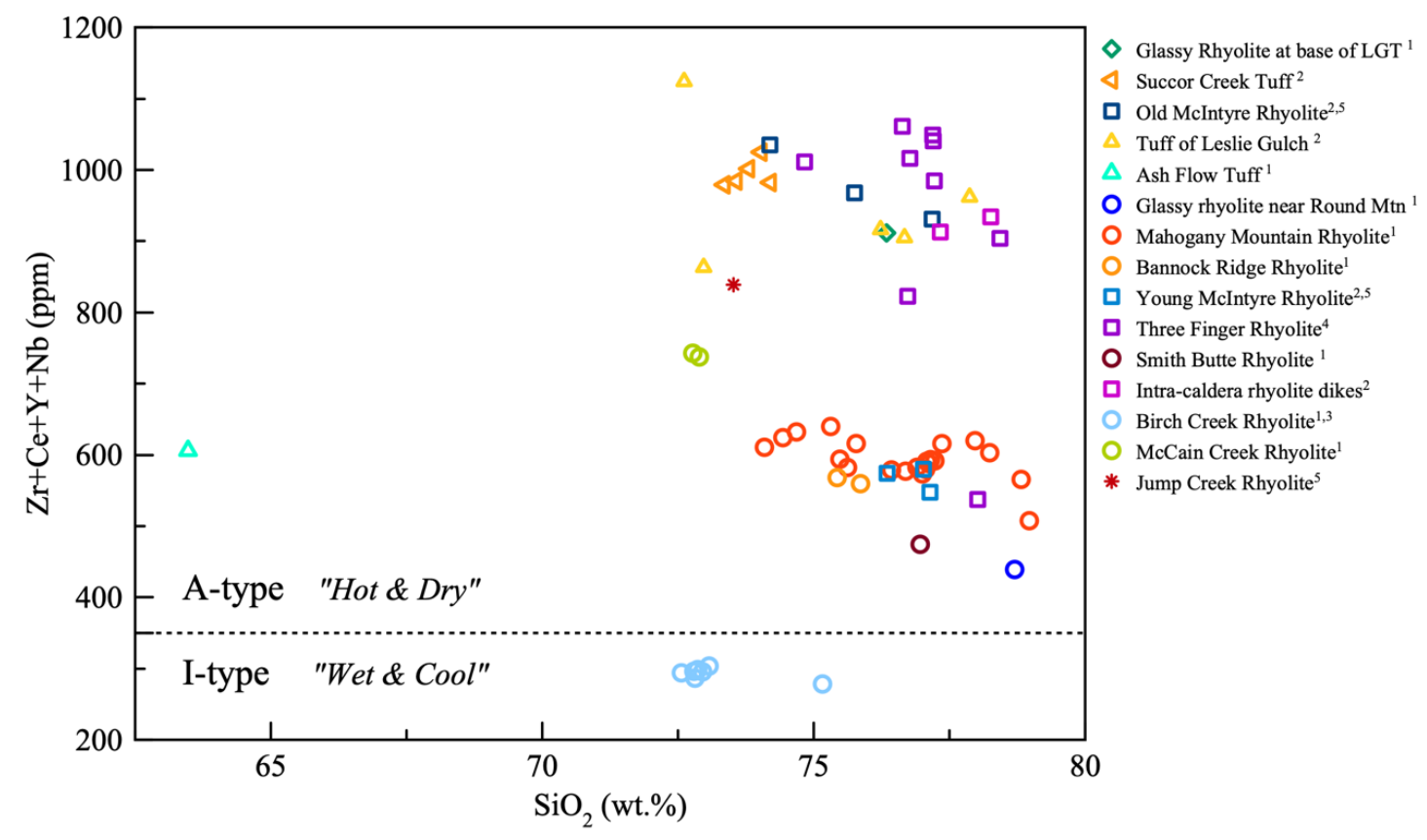

Figure 56. A-type vs I-type plot, showing the characterization of the MM-TF rhyolites based on sums of incompatible elements $\mathrm{Zr}, \mathrm{Ce}$, Y, and $\mathrm{Nb}$. Birch Creek is the only I-type rhyolite sampled, all other rhyolite units are of A-type affinity. ${ }^{1}$ : samples of this study. ${ }^{2}$ : samples of Streck \& others. ${ }^{3}$ : samples of Swenton, unpub. ${ }^{4}$ : samples of Marcy, 2013. ${ }^{5}$ : samples of Hess, 2014.

Rhyolites of the MM-TFrf dominantly exhibit an A-type affinity, with mineral assemblages reflecting this geochemical distinction (Fig. 56). A-type rhyolites of this study typically display a single feldspar, Na-rich sanidine, anorthoclase, or low-An plagioclase, Fe-rich clinopyroxene, such as ferrohedenbergite and ferroaugite, Fe-Ti oxides, and zircon. These mineral assemblages are consistent with dry conditions within the magmatic source (Christiansen et al., 2008). The one volatile-containing phase identified within the A-type rhyolites was apatite, which occurs in trace amounts and crystallizes as the main host of phosphorous. However, there are two distinct groups of rhyolites, one that display higher sums of $\mathrm{Zr}, \mathrm{Nb}, \mathrm{Y}, \mathrm{Ce}$, and one with lower, with a few others that fall in between such as the McCain Creek rhyolite which displays A-type characteristics with a mineral assemblage and sums of values of $\mathrm{Zr}, \mathrm{Nb}, \mathrm{Y}$, and $\mathrm{Ce}$ above 
$350 \mathrm{ppm}$, in agreement with having been sourced from a hotter, drier, more reduced parental source.

The Birch Creek rhyolite was the only unit found to exhibit I-type characteristics, having a mineral assemblage comprised of hydrous mineral phases, i.e., biotite and amphibole, and sum of high field strength element values below $350 \mathrm{ppm}$ (Fig. 56). This mineral assemblage is in agreement with having been sourced from a cooler, wetter, more oxidized magma, likely generated by heating of hydrous, accreted oceanic crust along the cratonic margin.

Given the country rock of the MM-TFrf is likely composed of the Old's Ferry terrane, which represents accreted oceanic crust considered to be quite hydrous due to interaction with seawater (Tumpane, 2010), it follows that a renewed heating event could produce an I-type rhyolite initially from partial melting of a hydrous source material and follow with more anhydrous, A-type rhyolites with continued heating. This aligns well with the timing and geochemical similarities of the Birch Creek and McCain Creek rhyolites, and provides additional support to their genetic relation. Interestingly, rhyolites with less enriched signature, contain pyroxene phenocrysts becoming slightly more $\mathrm{Mg}$ rich and feldspars becoming more like those observed in I-type rhyolites (Streck, person. comm., 2020).

The mineral assemblages of the A-type rhyolites of this study are consistent with those reported for rhyolites of the Snake River Plain (SRP) (Girard \& Stix, 2009). SRP rhyolites are often described as anhydrous with $\mathrm{SiO}_{2}$ content ranging from $70-75 \%$, high $\mathrm{FeO} * \mathrm{MgO}$, and high concentrations of high field strength elements $(\mathrm{Zr}+\mathrm{Nb}+\mathrm{Ce}+\mathrm{Y}$ values between 500-1000 ppm reported) (Christiansen, 2005; Bonnichsen et al., 2007). 
The common minerals reported for SRP rhyolites are plagioclase, alkali feldspar (most often as sanidine, some anorthoclase), Fe-rich pyroxene (commonly as ferroaugite or pigeonite), Fe-Ti oxides, and rare occurrences of fayalite, along with accessory apatite and zircon (Christiansen, 2005).

Typically, A-type rhyolites in a continental setting are associated with bimodal provinces, commonly flood basalt provinces, whereas I-type rhyolites are associated with calc-alkaline volcanic suites in volcanic arc and intra-continental settings (Streck \& Grunder, 2008). The majority of the rhyolites of this study are classified as A-type rhyolites and are associated with bimodal volcanism and high temperature emplacement. The production of the hot \& dry magmas is thought to be result of impingement of the Yellowstone mantle plume, heating and partial melting of Mesozoic-age granodioritic plutons and accreted oceanic crust along the North American cratonic margin. With this supplied heat and relative buoyancy, these hot $\&$ dry magmas are thought to rise and erupt within the MM-TFrf as expressions of silicic volcanism produced by Grande Ronde Basalt magmas underplating the Old's Ferry accreted terrane.

\section{$5.3 \delta^{18} \mathrm{O}$ Isotopes for Mahogany Mountain-Three Fingers rhyolites}

Rhyolites of the Mahogany Mountain-Three Fingers rhyolite field display low to normal (4.2 to $6.9 \%$ ) $\delta^{18} \mathrm{O}_{\text {melt }}$ values (Fig. 57). Low $\delta^{18} \mathrm{O}$ units consist of the Old McIntyre rhyolite, tuff of Leslie Gulch, the ash-flow tuff unit of this study, the tuff of Succor Creek, the Smith Butte rhyolite and the McCain Creek rhyolite. The ash-flow tuff and tuff of Succor Creek display $\delta^{18} \mathrm{O}_{\text {melt }}$ values of 5.5 and $4.8 \%$, respectively. Benson et al. (2013) reports a $\delta^{18} \mathrm{O}_{\text {melt }}$ value for the tuff of Leslie Gulch $\left(\delta^{18} \mathrm{O}_{\text {melt }}=+4.8 \%\right.$ ), which agrees with other members of the composite tuff of Leslie Gulch. The Jump Creek 
rhyolite displays the only high $\delta^{18} \mathrm{O}$ value $(8.7 \%$ ) for the MM-TFrf but is considered to belong to the rhyolites of the Owyhee Front and known to erupt much later than most rhyolites of the MM-TFrf (Hess, 2014).

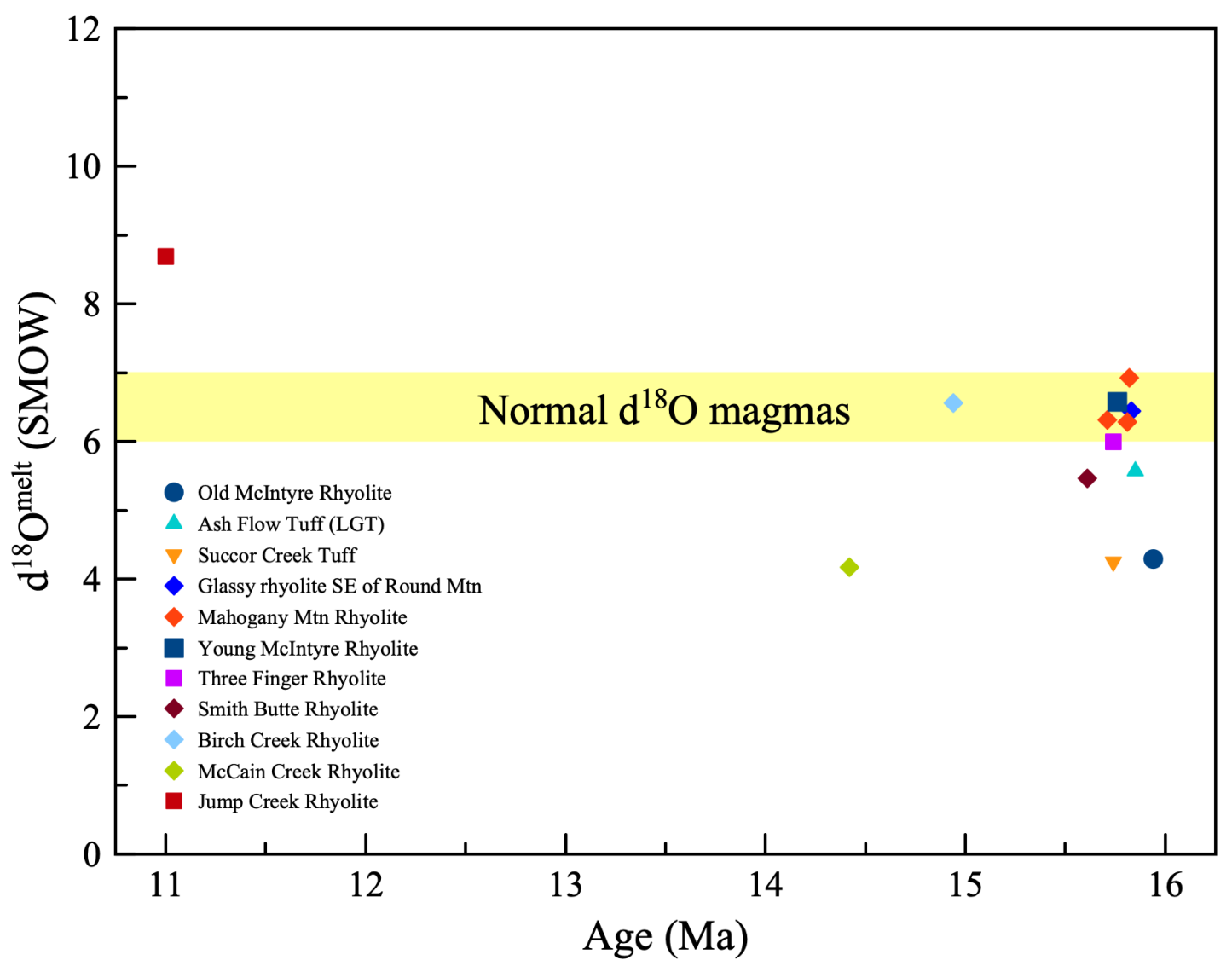

Figure 57. $\delta^{18} \mathrm{O}$ Isotopic values calculated for magmatic values for rhyolites of the MM-TFrf plotted with known age in time. Values were calculated from mineral values using equations in Appendix E.

Rhyolites with low- $\delta^{18} \mathrm{O}$ magmatic values $\left(\delta^{18} \mathrm{O}<6.0 \%\right)$ are thought to be generated by either the assimilation or melting of existing low- $\delta^{18} \mathrm{O}$ rock (Bindeman et al., 2004; Colón et al, 2015), or by extensional tectonics aiding in circulation of low- $\delta^{18} \mathrm{O}$ meteoric waters altering existing material (Blum et al., 2016). Bindeman \& Simakin (2014) propose a three-stage process for producing low- $\delta^{18}$ O rhyolites, consisting of 1 ) 
hydrothermal alteration of the protolith by low $\delta^{18} \mathrm{O}$ meteoric waters at large water/rock ratios; 2) remelting and convective mixing of low $\delta^{18} \mathrm{O}$ oxygen is homogenized in a newly formed magma batch; and 3) nucleation of new crystals representing batchaveraged $\delta^{18} \mathrm{O}$ compositions. The production of low- $\delta^{18} \mathrm{O}$ rhyolites is constrained to shallow depths due to meteoric water equilibrating with surrounding country rock before reaching depths of 5-10 km (Bindeman \& Simakin, 2014). With circulation of meteoric water being aided by syn-volcanic extension within the Oregon-Idaho graben during MM-TFrf volcanism, Colón et al. (2015) and Blum et al. (2016) propose models facilitating the normal faulting and hydrothermal alteration as the main drivers for the production of low- ${ }^{18} \mathrm{O}$ rhyolites in the $\mathrm{MM}-\mathrm{TFrf}$ as result of heating and extension from the Yellowstone mantle plume. This model is in agreement with the country rock of the Old's Ferry terrane likely having a more normal $\delta^{18} \mathrm{O}$ signature as displayed in the Mahogany Mountain and Young McIntyre rhyolites, and low- $-\delta^{18} \mathrm{O}$ rhyolites of the MM-TFrf being product of plume-driven hydrothermal alteration aided by normal faulting and extension in the Oregon-Idaho graben (Colón et al., 2015; Blum et al., 2016).

\subsection{Petrogenetic relationships}

Post-caldera volcanism in terms of geochemical evolution and genetic relationships can be modeled using batch melting, also known as 'partial melting', and Raleigh fractionation, also known as 'fractional crystallization', equations to better understand the magmatic processes potentially responsible for producing the rhyolite lavas observed at the MM-TFrf. Here we explore potential genetic relationships of MM-TFrf units using partial melting and fractional crystallization. 


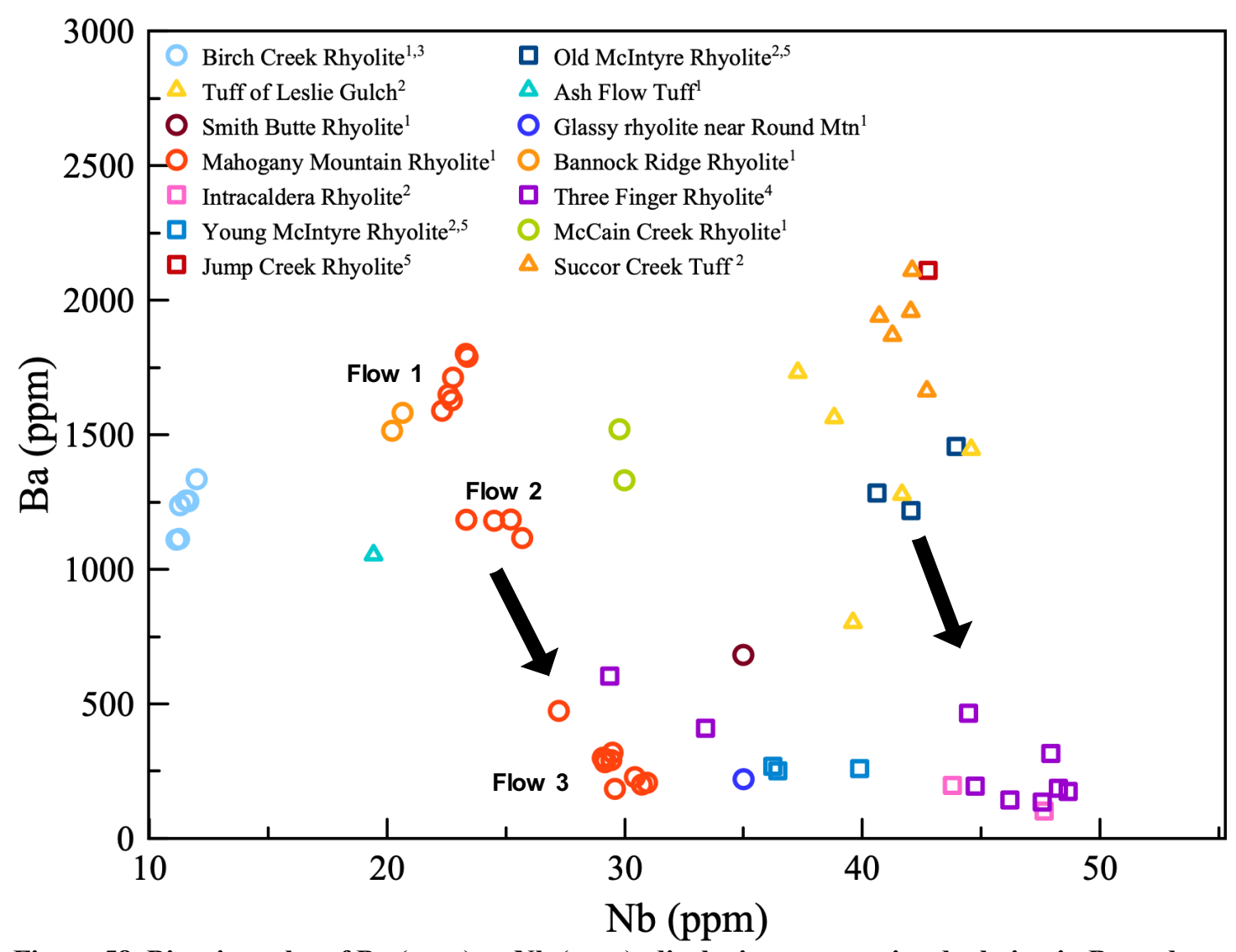

Figure 58. Bivariate plot of $\mathrm{Ba}(\mathrm{ppm})$ vs $\mathrm{Nb}(\mathrm{ppm})$, displaying progressive depletion in Ba and enrichment in Nb, with eruptions of the Mahogany Mountain rhyolite suite and Three Fingers rhyolite. ${ }^{1}$ : units of this study. ${ }^{2}$ : Streck \& others. ${ }^{3}$ : Swenton, unpub. ${ }^{4}$ : Marcy, 2013. ${ }^{5}$ : Hess, 2014.

Using the ages and geochemical signatures of rhyolites of the MM-TFrf, we can observe trends in depletion of $\mathrm{Ba}$ and enrichment of $\mathrm{Nb}$ with time and successive eruptions of the Mahogany Mountain rhyolite, and possibly with evolution of the tuff of Leslie Gulch rhyolite magma to the post-caldera effusive eruptions of the Three Fingers intra-caldera rhyolite lavas (Fig. 58). With these observations, we explore the potential magmatic processes to explain these trends using partial melting and fractional crystallization modelling of known unit signatures to determine the potential of a parentdaughter relationships of subsequent units in the MM-TFrf. 


\subsubsection{Evolution within the Mahogany Mountain rhyolites}

Through time and successive flow units, we observe depletions in $\mathrm{Ba}, \mathrm{Eu}$, and $\mathrm{Sr}$, as well as enrichment in $\mathrm{Nb}$ and Ta. With feldspar as the dominant mineral phase for the MMR, the depletion in feldspar compatible elements ( $\mathrm{Ba}, \mathrm{Eu}$, and $\mathrm{Sr}$ ) would be indicative of feldspar fractionation from the parent magma and would also enrich the melt in large ion lithophile elements (LILEs) and high field strength elements (HFSEs) not compatible with minerals nucleating in the melt. Modeling of the Mahogany Mountain rhyolite flow unit 1 supports fractional crystallization as the likely process responsible for production of the subsequent flow units of the Mahogany Mountain rhyolite suite. Our modeling results suggest the MMR flow unit 2 can be produced via approximately $\sim 5-10 \%$ fractional crystallization of flow unit 1 (Fig. 59 \& 61), displaying similar depletions in $\mathrm{Ba}, \mathrm{Sr}$, and Eu as observed in subsequent flow units. Additionally, flow unit 3 could be produced with $\sim 10-20 \%$ fractional crystallization from the MMR flow unit 2 magma (Fig. 60 \& 61). Modeling results, paired with observed geochemical evolution of the MMR, provide strong evidence for fractional crystallization being the dominant process responsible for geochemical evolution within the MMR suite. 


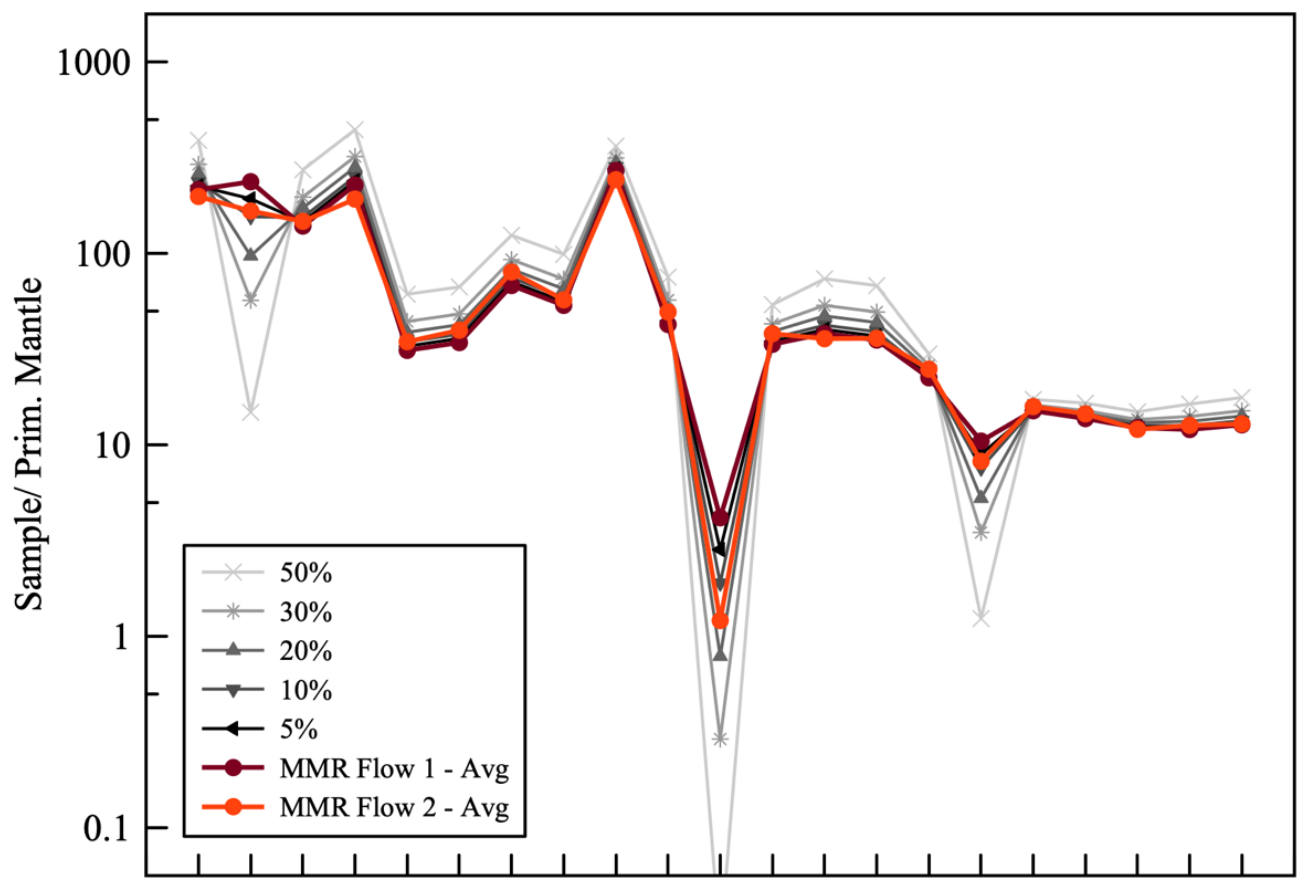

$\mathrm{Rb} \mathrm{Ba} T \mathrm{Th} \mathrm{Nb}$ Ta La Ce Pb Pr $\mathrm{Sr} \mathrm{Nd} \mathrm{Zr}$ Hf Sm Eu Tb Dy Y Yb Lu

Figure 59. Fractional crystallization modeling results of a calculated average for the MMR flow unit 1, compared with the average for MMR flow unit 2. Spider diagram has been modified to exclude major elements that could not be modeled, and these results have been normalized to primitive mantle, Sun \& McDonough (1989).

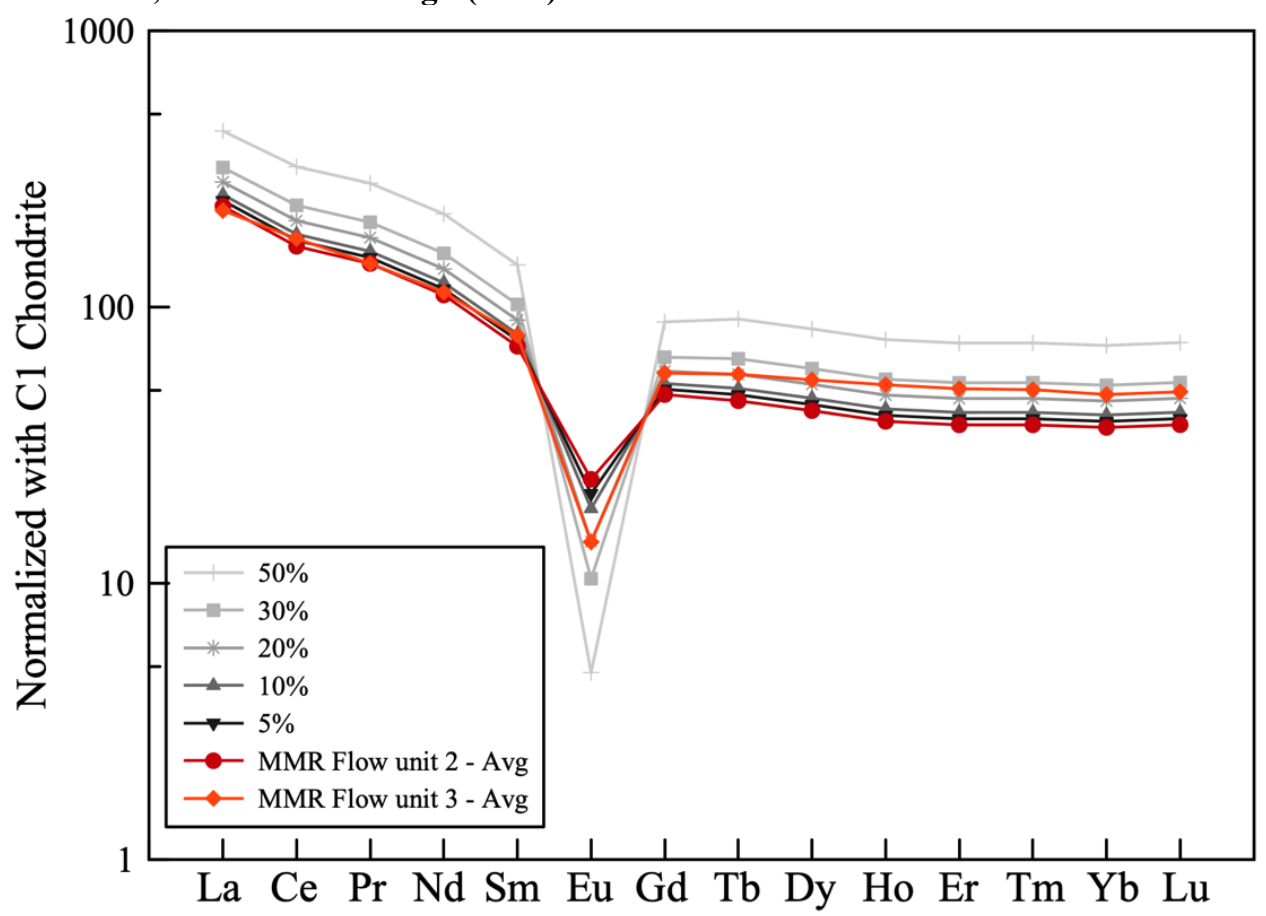

Figure 60. Rare earth element diagram of fractional crystallization modeling of MMR flow unit 2, shown to produce similar concentrations to flow unit 3 at 10-20\% fractional crystallization. Samples and modeling results were normalized to C1 chondrite, McDonough \& Sun (1995). 


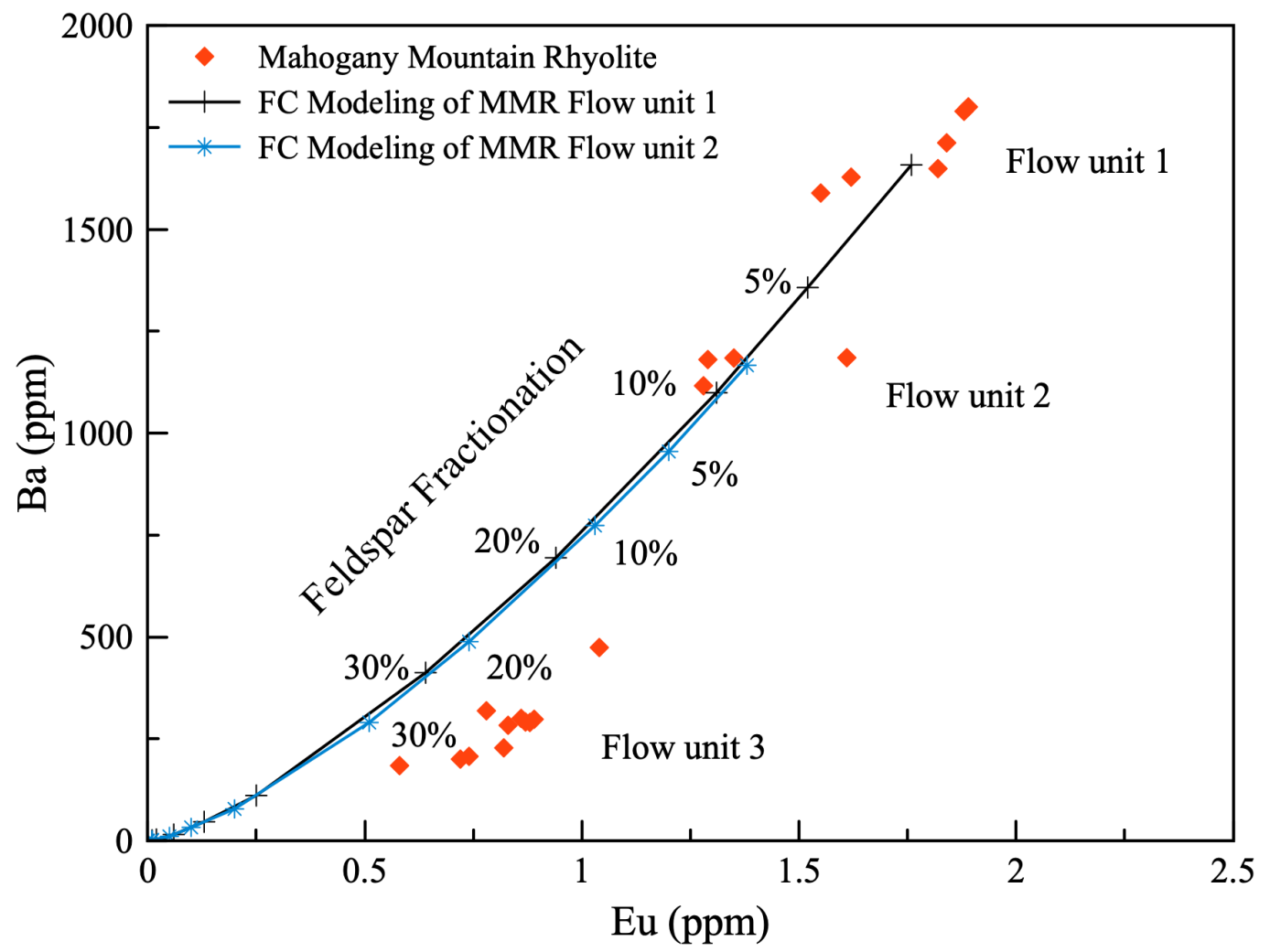

Figure 61. Bivariate plot of Ba vs Eu, displaying feldspar fractionation trends and modeling results for fractional crystallization of successive flows of the MMR. Modeled lines of descent are shown in connected black and grey lines, with degrees of fractional crystallization. Partition coefficients used: Ba (7) \& Eu (4.75).

Flow units of the Mahogany Mountain rhyolite suite all reflect normal $\delta^{18} \mathrm{O}_{\text {melt }}$ values (6.3-6.9\%) and display small variations between units. The interpreted initial flow unit of the MMR $(15.81 \pm 0.06 \mathrm{Ma})$, displays a $\delta^{18} \mathrm{O}_{\text {melt }}$ value of $6.5 \%$. The second flow unit (15.82 $\pm 0.05 \mathrm{Ma})$, erupting temporally close to the initial flow unit, exhibits a $\delta^{18} \mathrm{O}_{\text {melt }}$ value of $6.9 \%$. The timing and an apparent increase in $\delta^{18} \mathrm{O}_{\text {melt }}$ value from flow unit 1 to flow unit 2, could be slight variation from heterogeneity of $\delta^{18} \mathrm{O}$ values in the melt. Flow unit 3 of the MMR, displays a lower $\delta^{18} \mathrm{O}_{\text {melt }}$ value of $6.3 \%$. Geochemical modeling of has shown subsequent flows could be produced with small degrees of fractionation. If partial melting was the dominant process, then the trend of lower Ba but 
higher $\mathrm{Nb}$ would signify lower degree of melting to enrich $\mathrm{Nb}$ and that alkali-feldspar is a significant residual phase in the source during lower degree of melting to generate low $\mathrm{Ba}$ in partial melt. There is no evidence that Olds Ferry crustal rocks are high in alkalifeldspar. In other words, we would not expect such depletion in feldspar compatible elements (Ba, $\mathrm{Sr}, \mathrm{Eu})$ with relatively small increases in incompatible elements (e.g., $\mathrm{Nb})$. Therefore, we interpret flow units of the MMR suite to be products of fractional crystallization and with normal $\delta^{18} \mathrm{O}$ values reflecting the signature of their shared source magma.

\subsubsection{Derivation of Mahogany Mountain rhyolites from the Leslie Gulch magma}

Emplacement of the post-caldera MMR suite right after the Tuff of Leslie Gulch begs the question whether tuff of Leslie Gulch type of magma or source rock could yield rhyolites of the MMR suite either by fractional crystallization or partial melting, respectively. Through application of partial melting and fractional crystallization modeling of trace element concentrations of the tuff of Leslie Gulch, we evaluate the potential means of derivation for the subsequent Mahogany Mountain rhyolite suite. We observe similar Ba concentrations compared with the tuff of Leslie Gulch, but significantly lower $\mathrm{Nb}$ concentrations in all of the Mahogany Mountain rhyolites (Fig. 58). Modeling results suggest that the Mahogany Mountain rhyolite cannot be produced by means of fractional crystallization or partial melting of the tuff of Leslie Gulch rhyolite magma (Fig. 62), given the MMR displays a less incompatible element enriched geochemical signature. All Mahogany Mountain rhyolites, the ones at higher concentration of $\mathrm{Ba}$ to those at low Ba concentrations, all have distinctly lower concentrations of most incompatible trace elements. Additional evidence is provided by 
the difference in $\delta^{18} \mathrm{O}$ values with the composite tuff of Leslie Gulch displaying a low$\delta^{18} \mathrm{O}$ values, and the subsequent MMR possessing a normal $\delta^{18} \mathrm{O}$ value. This would support the interpretation that the Mahogany Mountain rhyolite represents a new batch of rhyolite and is not derived from recycling of a solidified Leslie Gulch type of rock or magma.

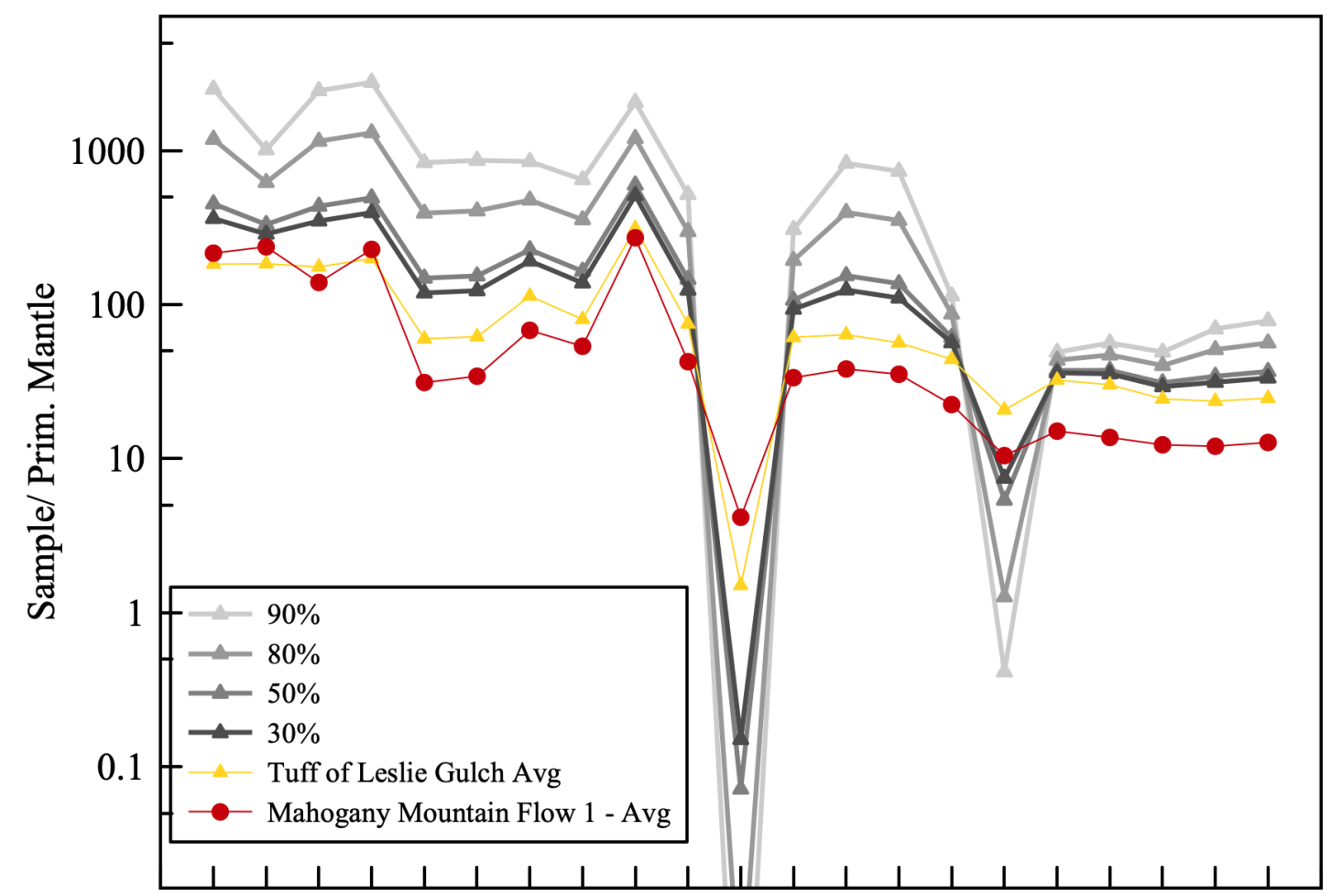

$\mathrm{Rb} \mathrm{Ba}$ Th $\mathrm{U}$ Nb Ta La Ce Pb Pr Sr Nd Zr Hf Sm Eu Tb Dy Y Yb Lu

Figure 62. Fractional crystallization modeling results of tuff of Leslie Gulch, sample number CB19-67, compared with the average for Mahogany Mountain rhyolite flow unit 1. Spider diagram has been modified to exclude major elements that could not be modeled, and these results have been normalized to primitive mantle, Sun \& McDonough (1989).

\subsubsection{Relationships among post-caldera rhyolites}

Most of the rhyolites of the MM-TFrf are linked spatially and temporally so the question arises to the nature of their genetic relationships. The majority of these rhyolites represent distinct rhyolite batches likely generated by partial melting of compositional 
heterogeneities in the crust yielding unique $\mathrm{Ba}$ and $\mathrm{Nb}$ concentrations (Fig. 58). Modeling of potential genetic relationships for most of the rhyolites of this study proved insufficient, suggesting many of these rhyolites are sourced from compositionally similar parent magmas but were not directly derived from one another.

The Mahogany Mountain suite is an exception, providing evidence for a genetic links between flow units through small degrees of fractional crystallization to produce successive flow unit signatures. Additionally, the MMR flow unit 1 was found to be compositionally and mineralogically similar to the Bannock Ridge rhyolite, suggesting these two lavas are sourced from the same magma (Fig. $58 \& 63$ ). Therefore, we rename the "Bannock Ridge rhyolite" and group it with flow unit 1 of the MMR suite.

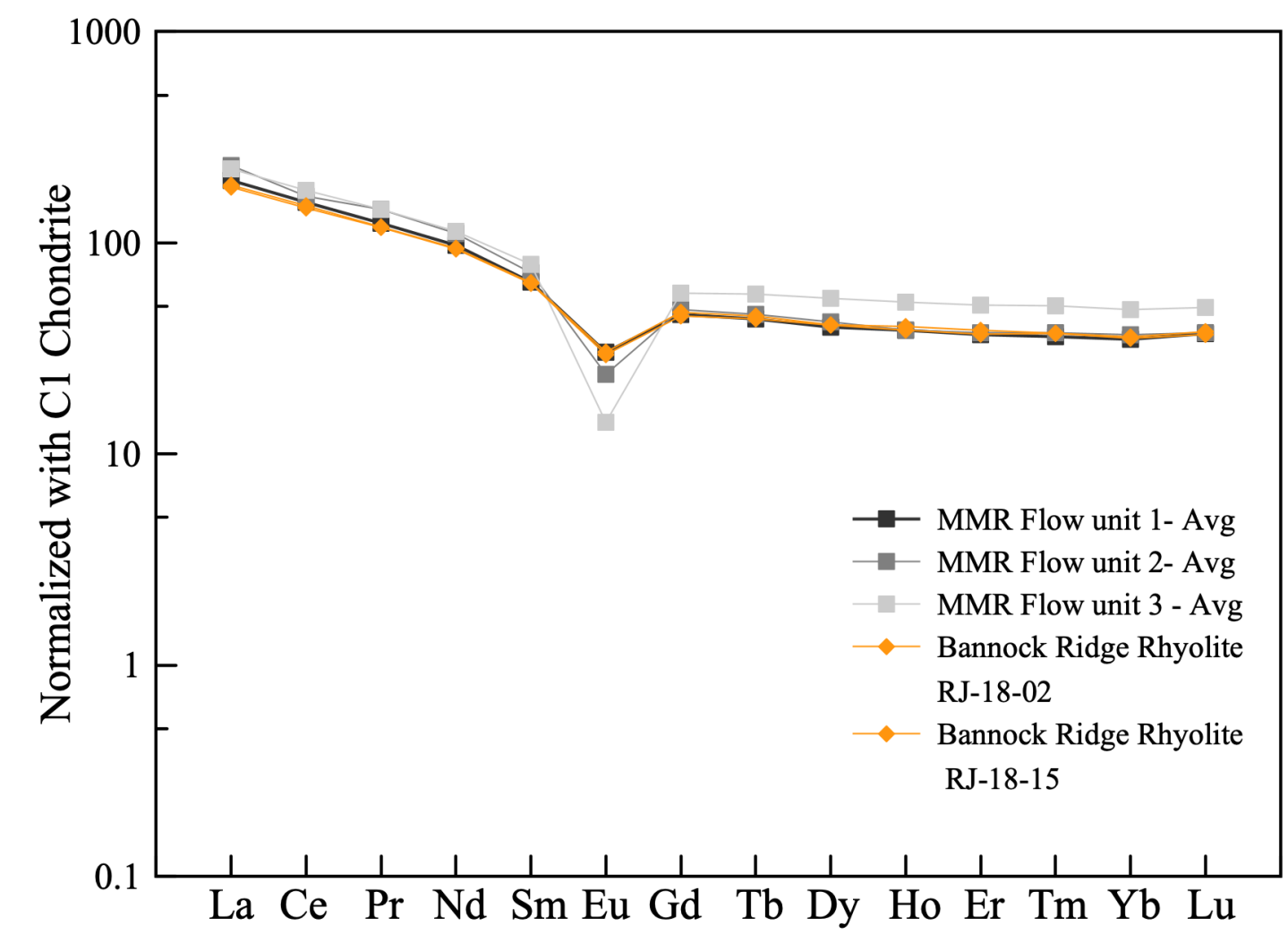

Figure 63. Rare earth element concentrations of the Bannock Ridge rhyolite plotted with averages for Mahogany Mountain rhyolite flow units. Samples are normalized to $\mathrm{C} 1$ chondrite, McDonough \& Sun (1995). 
The Three Fingers rhyolite was thought to potentially share a genetic relationship with the precursor tuff of Leslie Gulch magma, based on Three Fingers samples falling at the end of the "high $\mathrm{Nb}$ suite" of figure 58. However, both units have similar LILEs, HFSEs, and HREEs concentrations yet have substantially different concentrations in feldspar compatible elements ( $\mathrm{Ba}, \mathrm{Sr}, \& \mathrm{Eu})$. Modeling of fractional crystallization of the tuff of Leslie Gulch proved insufficient to produce observed depletions in feldspar compatible elements while keeping incompatible elements at comparable concentrations of Leslie Gulch samples (Fig. 64).

Furthermore, the tuff of Leslie Gulch was not analyzed for $\delta^{18} \mathrm{O}$ stable isotopes as a part of this study, however Benson et al. (2013) report a $\delta^{18} \mathrm{O}_{\text {melt }}$ value of $4.8 \%$. Using this $\delta^{18} \mathrm{O}_{\text {melt }}$ signature paired with $\delta^{18} \mathrm{O}_{\text {melt }}$ values of the tuff of Succor Creek $\left(\delta^{18} \mathrm{O}_{\text {melt }}=\right.$ $+4.8 \%$ ) and ash-flow tuff $\left(\delta^{18} \mathrm{O}_{\text {melt }}=+5.5 \%\right.$ of this study, we characterize the tuff of Leslie Gulch and associated units as low- $\delta^{18} \mathrm{O}$ rhyolites. The Three Fingers rhyolite displays a $\delta^{18} \mathrm{O}_{\text {melt }}$ value of $6.3 \%$, reflecting a normal $\delta^{18} \mathrm{O}$ signature. This stark difference and increase in $\delta^{18} \mathrm{O}_{\text {melt }}$ signatures from the composite tuff of Leslie Gulch to the subsequent Three Fingers rhyolite suggests these two units are not directly related by a parent-daughter scenario, but more likely that the parent magma to yield the Three Fingers rhyolite by fractional crystallization was generally compositionally similar to Leslie Gulch magma but slightly less enriched and with a normal $\delta^{18} \mathrm{O}$ signature. 


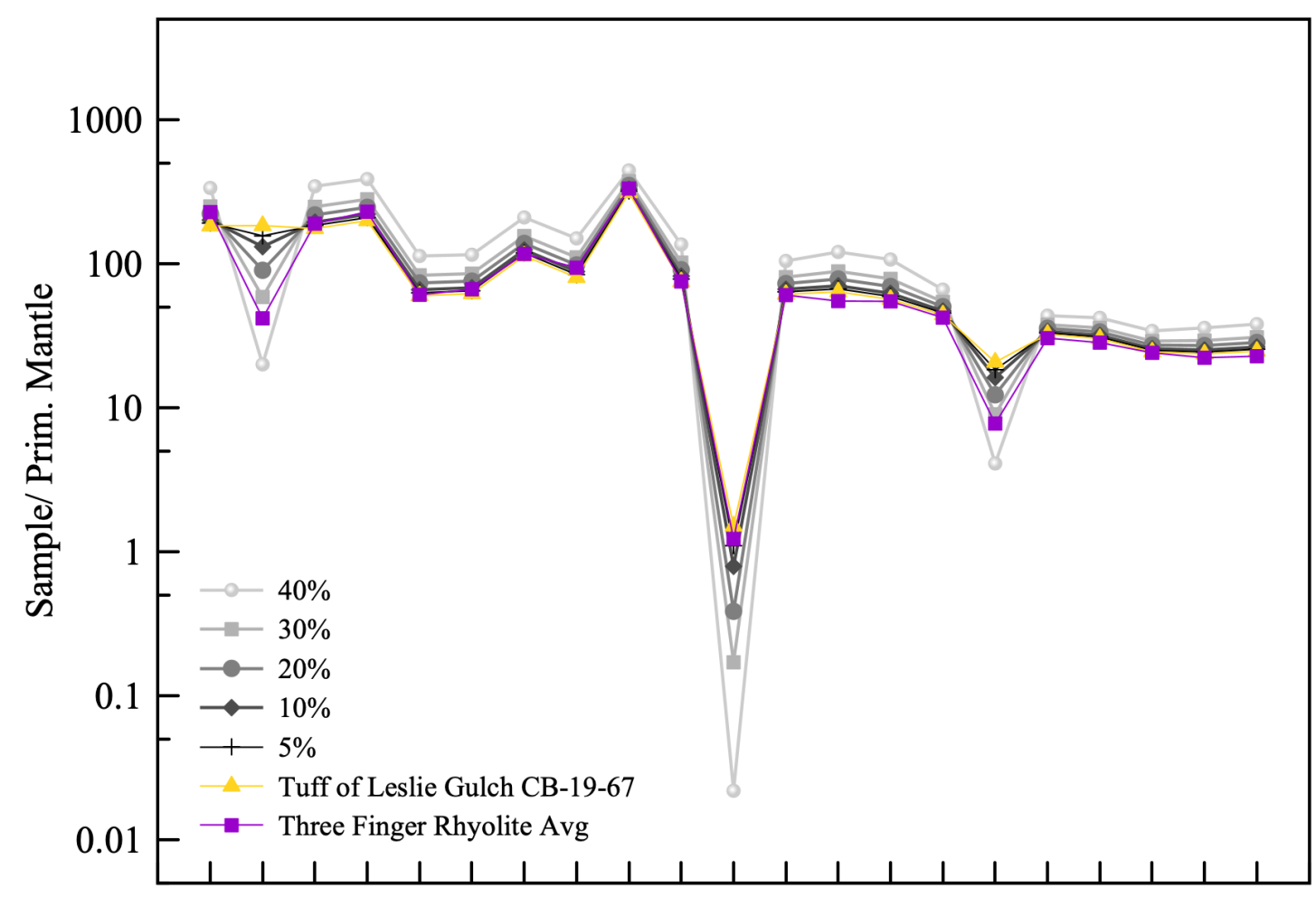

$\mathrm{Rb} \mathrm{Ba}$ Th $\mathrm{U}$ Nb Ta La Ce Pb Pr Sr Nd Zr Hf Sm Eu Tb Dy Y Yb Lu

Figure 64. Fractional crystallization modeling results of the tuff of Leslie Gulch, sample number CB-19-67, compared with the calculated average of the Three Fingers rhyolite. Spider diagram has been modified to exclude major elements that could not be modeled, and these results have been normalized to primitive mantle, Sun \& McDonough (1989).

\subsection{Rhyolite Generation at the Mahogany Mountain-Three Fingers rhyolite field}

Mid-Miocene silicic volcanism at the MM-TFrf is temporally and spatially related with flood basalt eruptions of Columbia River Basalt province, and rhyolite generation is largely attributed to heating and extensional tectonics result of the Yellowstone mantle plume thought to be positioned at the base of the lithosphere beneath Oregon, Idaho and Nevada (Camp et al., 2003; Coble \& Mahood, 2012; Colón et al, 2015). Approximately, $1115 \mathrm{~km}^{3}$ of rhyolitic material was emplaced within the Lake Owyhee Volcanic Field, including the Castle Rock caldera and Mahogany MountainThree Fingers rhyolite field (Coble \& Mahood, 2012). Silicic volcanism is active from 
16.02 to $15.71 \mathrm{Ma}$, with emplacement of at least 9 geochemically distinct rhyolite batches in the span of approximately 300 thousand years. These rhyolites are thought to be generated by basaltic underplating of a Grande Ronde-like magma, which could provide sufficient heat to partially melt intermediate to felsic crust and produce the rhyolites observed at the surface. This is proposed based on 1) the timing of rhyolite volcanism with the end of Grande Ronde volcanism (ca. 16.0 Ma) (Wolff \& Ramos, 2013; Webb et al., 2018), 2) the spatial and temporal association with the Hunter Creek Basalt, and Lower and Upper Littlefield rhyolites (16.11 and 16.02 Ma, respectively) along the western border of the Oregon-Idaho graben (Webb et al., 2018), and 3) the spatial and temporal relationship to the Castle Rock caldera and Dinner Creek tuff (16.15 Ma), which has been shown to contain Grande Ronde mafic components and provide evidence for Grande Ronde magma storage beneath the Dinner Creek tuff eruptive center (Streck et al., 2015). Rhyolite magma chambers in the upper crust can act as rheological and possible density barriers to rising mafic magmas, causing them to pond and erupt subsequent to rhyolites or be redirected to peripheral areas (Streck et al., 2015). This likely played a large role in the rhyolite petrogenesis experienced at the MM-TFrf, with silicic magmas acting as rheological barriers to underplating basaltic magmas of the Grande Ronde emplaced along the western edge of the Oregon-Idaho graben and within the Malheur Gorge area (Webb et al., 2018).

Rhyolites of the MM-TFrf are dominantly A-type rhyolites associated with hot, dry, and reduced magmas. A-type rhyolites sourced from presumably hydrated, oceanic crust with low- to normal $\delta^{18} \mathrm{O}$ values show strong evidence for having been generated by intrusion of a hot basalt magma in the crust by a deep-seated mantle plume (Fig. 65) 
(Coble \& Mahood, 2012; Colón et al, 2015). Most of the rhyolite units present appear to be unique magma batches derived likely by either partial melting or fractional crystallization of a granodioritic pluton and subsequent extraction of interstitial melt from a crystal mush (Bachman \& Bergantz, 2004; Streck \& Grunder, 2008). It is also possible heat supplied from the basaltic underplating partially melted the accreted oceanic material of the Olds Ferry terrane (Tumpane, 2010), which comprises the country rock surrounding the Lake Owyhee Volcanic Field prior to mid-Miocene volcanism, and could generate the silicic magmas of the MM-TFrf with normal $\delta^{18} \mathrm{O}$ signatures, and subsequent alteration via meteoric water could influence existing magmas to produce the low- $-\delta^{18} \mathrm{O}$ signatures of select Mahogany Mountain—Three Fingers rhyolites. Through time, composite tuff of Leslie Gulch and Smith Butte rhyolite magmas erupt following and along with normal $\delta^{18} \mathrm{O}$ rhyolites, suggesting normal faulting may have initiated earlier than previously thought altering their respective signatures, and low- $\delta^{18} \mathrm{O}$ rhyolite magmas likely reside at shallow depths relative to normal $\delta^{18} \mathrm{O}$ rhyolite magmas (Fig. $65)$. 


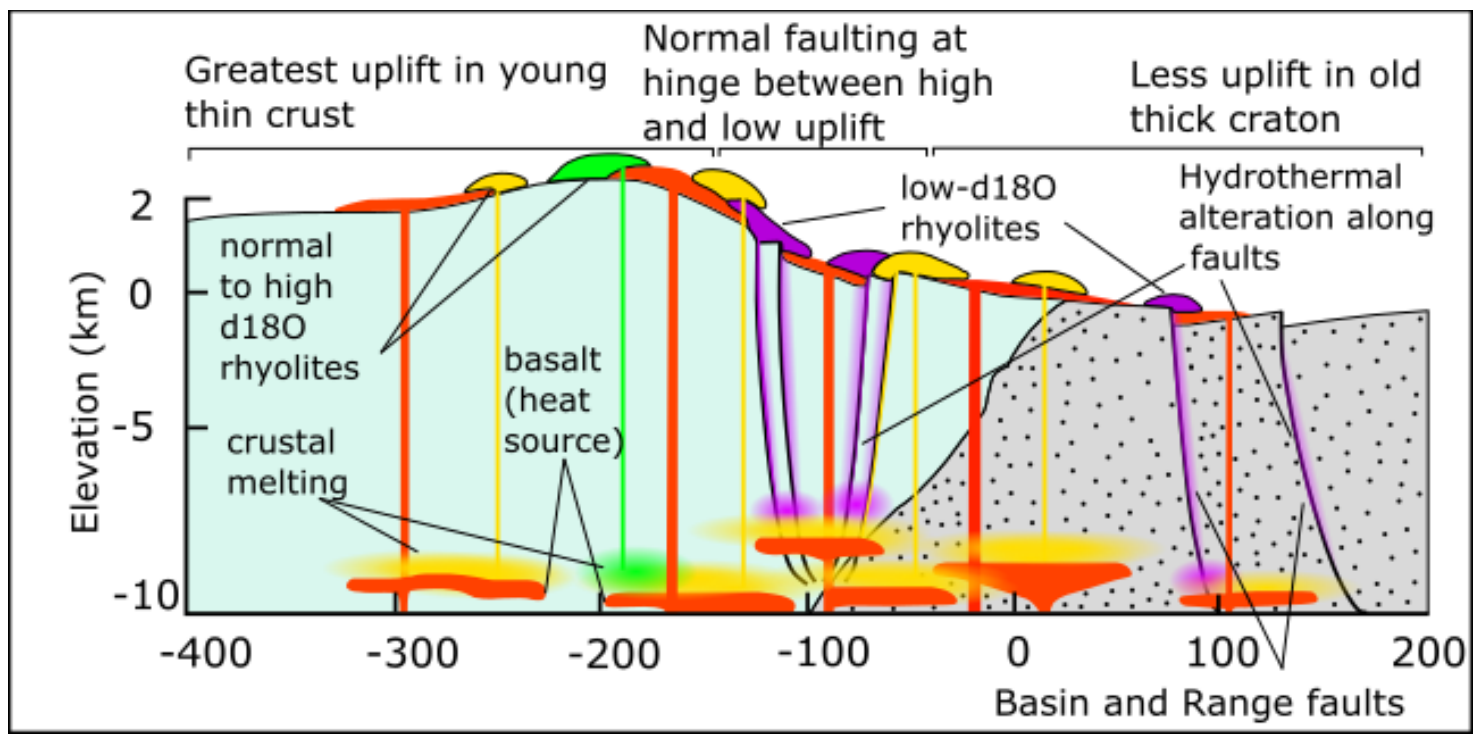

Figure 65. Rhyolite generation model displaying basalts as likely heat source to partially melt crustal material to generate normal to high $-\delta^{18} O$ signatures. Low- $\delta^{18} O$ rhyolites are produced through normal faulting and alteration by meteoric waters. Modified from Colón et al. (2015).

\subsection{Stratigraphy \& Oregon-Idaho Graben development}

Mahogany Mountain - Three Fingers rhyolites can be divided into syn- and postcaldera units based on stratigraphic evidence and ${ }^{40} \mathrm{Ar} /{ }^{39} \mathrm{Ar}$ ages. Pairing this distinction with any observed evidence of normal faulting can provide clues to the history of volcanism for the rhyolite field as well as document Oregon-Idaho graben development. Syn-caldera units are likely derived from active volcanism of the MM-TFrf and could indicate locations of caldera ring fractures or vents to the underlying system. Whereas the location and timing of post-caldera rhyolite lavas may provide clues to the position of silicic magmas and normal faults, which provide pathways from the underlying magma chambers to the surface, as well as document extension related volcanism for the rhyolite field and Oregon-Idaho graben.

The ash-flow tuff member of the cTLG is the only syn-caldera unit of this study, emplaced at the waning stages of caldera formation and as a final member of the 
composite tuff of Leslie Gulch sequence. Post-caldera units include the 'rhyolite SE of Round Mtn', flow units of the Mahogany Mountain rhyolite suite, the Bannock Ridge rhyolite, the Smith Butte rhyolite, the Birch Creek rhyolite, and McCain Creek rhyolite. These units are emplaced atop tuffaceous sediments, and often show evidence of being cut by normal faulting. Additionally, there are three N-S trending fault zones within the MM-TFrf which are from east to west, the Devil's Gate fault zone, the Dry Creek Butte fault zone, and the Wall Rock Ridge fault zone (Cummings et al., 2000), with many postcaldera units located adjacent to or within these fault zones (Fig. 11). The presence of normal faults, and presence of an existing caldera ring fracture, could not only provide pathways for these rhyolite magma's ascent to the surface but also provides a means for meteoric waters to alter their respective $\delta^{18} \mathrm{O}$ signature. The Smith Butte rhyolite could be a product of these interactions given its location within the Devil's Gate fault zone and its low- $\delta^{18} \mathrm{O}$ signature $(+5.4 \%)$.

Oregon-Idaho graben development is thought to have begun ca. 15.5 Ma with eruptions of rhyolite tuffs and lavas within and peripheral to the OIG (Cummings et al., 2000). We find the timing of two low- $\delta^{18} \mathrm{O}$ magmas (e.g., Old McIntyre rhyolite and tuff of Leslie Gulch) to be emplaced prior to post-caldera, normal- $-\delta^{18} \mathrm{O}$ magmas (e.g., Mahogany Mountain rhyolite and Young McIntyre rhyolite) (Fig. 57) suggesting graben development began prior to $16 \mathrm{Ma}$, producing normal faults within the graben as conduits for alteration. Additionally, observations of post-caldera units often being cut by N-S trending normal faults and many being emplaced within major fault zones of the OIG, we infer crustal extension during graben development played a role in the emplacement of post-caldera MM-TF rhyolites. 


\section{CONCLUSION}

Our data suggest mid-Miocene rhyolite volcanism at the MM-TFrf is voluminous and diverse with emplacement of at least nine geochemically distinct, high temperature rhyolite lavas and tuffs, marking the initiation of rhyolite petrogenesis for the Oregon-Idaho graben and following the rhyolite eruptions of the Upper and Lower Littlefield rhyolite flow units and the Dinner Creek Tuff to the west. Rhyolite generation is attributed to basaltic underplating of likely Grande Ronde Basalt magmas, which could provide sufficient heat to induce partial melting and subsequent fractional crystallization of silicic crustal material required to produce the volume of rhyolite volcanism present in the MM-TFrf.

New ${ }^{40} \mathrm{Ar} /{ }^{39} \mathrm{Ar}$ ages for Mahogany Mountain-Three Fingers rhyolites illustrate initiation ca. 16.02 Ma with emplacement of a pre-caldera rhyolite lava prior to the episodic composite tuff of Leslie Gulch, erupting over an interval of 15.98 to $15.74 \mathrm{Ma}$, and interpreted to represent repetitive phreatomagmatic eruptions. The Mahogany Mountain rhyolite suite represent post-caldera effusive rhyolite eruptions sourced from a new rhyolite batch and emplaced in a three-stage sequence from 15.82 to $15.71 \mathrm{Ma}$ along the inferred southeastern caldera ring fracture. Geochemical modeling strongly suggests subsequent flow units of the MMR were produced via small degrees ( $\sim 5-20 \%)$ of fractional crystallization. Additional modeling suggests the remainder of $\mathrm{MM}-\mathrm{TF}$ rhyolite units represent distinct rhyolite batches generated from compositionally similar silicic crust, each with unique $\mathrm{Ba}$ and $\mathrm{Nb}$ concentrations from their respective parent material. Main phase rhyolite volcanism concluded ca. 15.71 Ma with eruption of the third flow unit of the Mahogany Mountain rhyolite and the Smith Butte rhyolite within 
the Devils Gate Fault zone. Following quiescence, reheating of the crust from magmatism of the Western Snake River Plain generated the Birch Creek rhyolite (14.94 Ma) and McCain Creek rhyolite (14.42 Ma) lavas in the southern end of the field. These new data constrain rhyolite volcanism of the MM-TFrf from to 16.02 to $15.71 \mathrm{Ma}$, spanning approximately 300 thousand years, and shift initiation of silicic activity back to be more contemporaneous with the end of the Grande Ronde Basalt. 


\section{REFERENCES}

Bachmann, O., \& Bergantz, G. W., 2004, On the origin of crystal-poor rhyolites:

extracted from batholithic crystal mushes: Journal of Petrology, v. 45, p. 1565-1582.

Bacon, C.R., \& Druitt, T., 1988, Compositional evolution of the zoned calc-alkaline magma chamber of Mount Mazama, Crater Lake, Oregon: Contributions to Mineralogy and Petrology, v. 98, p. 224-256.

Barry, T. L., Kelley, S. P., Reidel, S. P., Camp, V. E., Self, S., Jarboe, N. A., ... \& Wells, R. E., 2013, Eruption chronology of the Columbia River Basalt Group. The Columbia River Flood Basalt Province: Geological Society of America Special Paper, v. 497, p. 4566.

Bas, M. L., Maitre, R. L., Streckeisen, A., Zanettin, B., \& IUGS Subcommission on the Systematics of Igneous Rocks., 1986, A chemical classification of volcanic rocks based on the total alkali-silica diagram: Journal of Petrology, v. 27, p. 745-750.

Bea, F., Pereira, M. D., \& Stroh, A., 1994, Mineral/leucosome trace-element partitioning in a peraluminous migmatite (a laser ablation-ICP-MS study): Chemical Geology, v. 117, p. 291-312.

Benson, T. R., Mahood, G. A., \& Grove, M., 2013, New geologic and geochronologic data on the Lake Owyhee Volcanic Field, Oregon: A silicic center contemporaneous with flood basalt volcanism: In Geological Society of America Abstracts with Programs, v. 45, p. 14.

Benson, T. R., \& Mahood, G. A., 2016, Geology of the mid-Miocene Rooster Comb caldera and Lake Owyhee volcanic field, eastern Oregon: Silicic volcanism associated with Grande Ronde flood basalt: Journal of Volcanology and Geothermal Research, v. 309, p. 96-117, doi: https://doi.org/10.1016/j.jvolgeores.2015.11.011

Bindeman, I. N., \& Valley, J. W., 2000, Formation of low- $\delta 18$ O rhyolites after caldera collapse at Yellowstone, Wyoming, USA: Geology, v. 28, p. 719-722.

Bindeman, I. N., \& Valley, J. W., 2001, Low- $\delta 18$ O rhyolites from Yellowstone: Magmatic evolution based on analyses of zircons and individual phenocrysts: Journal of Petrology, v. 42, p. 1491-1517.

Bindeman, I., 2008, Oxygen isotopes in mantle and crustal magmas as revealed by single crystal analysis: Reviews in Mineralogy and Geochemistry, v. 69, p. 445-478.

Bindeman, I. N., \& Simakin, A. G., 2014, Rhyolites-Hard to produce, but easy to recycle and sequester: Integrating microgeochemical observations and numerical models: Geosphere, v. 10, p. 930-957. 
Black, C., Streck, M. J., 2021, Stratigraphy of the Succor Creek Area: updating the explosive and effusive chronology at the Mahogany Mountain-Three Fingers rhyolite field: Geological Society of America Abstracts with Programs, v. 53, no. 4, doi:10.1130/abs/2021CD-363253

Blum, T. B., Kitajima, K., Nakashima, D., Strickland, A., Spicuzza, M. J., \& Valley, J. W., 2016, Oxygen isotope evolution of the Lake Owyhee volcanic field, Oregon, and implications for the low- $\delta 18 \mathrm{O}$ magmatism of the Snake River Plain-Yellowstone hotspot and other low- $\delta 18 \mathrm{O}$ large igneous provinces: Contributions to Mineralogy and Petrology, v. 171, p. 1-23.

Bonnichsen, B., Leeman, W. P., Honjo, N., McIntosh, W. C., \& Godchaux, M. M., 2008, Miocene silicic volcanism in southwestern Idaho: geochronology, geochemistry, and evolution of the central Snake River Plain: Bulletin of Volcanology, v. 70, p. 315-342.

Broderick, C.A., 2008, The origin of sulfur-rich apatites in silicic magmas [M.Sc. thesis]: Portland State University.

Brown, E.A., 2017, Rhyolite petrogenesis at Tower Mountain caldera, Oregon [M.Sc. thesis]: Portland State University.

Camp, V. E., Ross, M. E., \& Hanson, W. E., 2003, Genesis of flood basalts and Basin and Range volcanic rocks from Steens Mountain to the Malheur River Gorge, Oregon: Geological Society of America Bulletin, v. 115, p. 105-128.

Christiansen, E. H., 2005, Contrasting processes in silicic magma chambers: evidence from very large volume ignimbrites: Geological Magazine, v. 142, p. 669-681.

Christiansen, E. H., \& McCurry, M., 2008, Contrasting origins of Cenozoic silicic volcanic rocks from the western Cordillera of the United States: Bulletin of Volcanology, v. 70, p. 251-267.

Coble, M. A., \& Mahood, G. A., 2012, Initial impingement of the Yellowstone plume located by widespread silicic volcanism contemporaneous with Columbia River flood basalts: Geology, v. 40, p. 655-658. doi: https://doi.org/10.1130/G32692.1

Colón, D. P., Bindeman, I. N., Stern, R. A., \& Fisher, C. M., 2015, Isotopically diverse rhyolites coeval with the Columbia River Flood Basalts: evidence for mantle plume interaction with the continental crust: Terra Nova, v. 27, p. 270-276.

Cummings, M. L., Evans, J. G., Ferns, M. L., \& Lees, K. R., 2000, Stratigraphic and structural evolution of the middle Miocene syn-volcanic Oregon-Idaho graben: Geological Society of America Bulletin, v. 112, p. 668-682. 
Darold, A., \& Humphreys, E., 2013, Upper mantle seismic structure beneath the Pacific Northwest: A plume-triggered delamination origin for the Columbia River flood basalt eruptions: Earth and Planetary Science Letters, v. 365, p. 232-242. Doi:

https://doi.org/10.1016/j.eps1.2013.01.024

Dickinson, W. R., 2004, Evolution of the North American cordillera: Annu. Rev. Earth Planet. Sci., v. 32, p. 13-45.

Ferns, M. L., 1997, Field Trip guide to the eastern margin of the Oregon-Idaho graben and the middle Miocene calderas of the Lake Owyhee volcanic field, in Oregon Geology, 59th, Field Trip Guidebook, Oregon Department of Geology and Mineral Industries, 9 p.

Ferns, M. L., \& Cummings, M. L., 1996, Geologic resources of the Vale and Mahogany Mountain 30' x 60' Quadrangles: State of Oregon Department of Geology and Mineral Industries Open File Report 0-94-10, 1 p.

Ferns, M. L., \& McClaughry, J. D., 2013, Stratigraphy and volcanic evolution of the middle Miocene to Pliocene La Grande-Owyhee eruptive axis in eastern Oregon. The Columbia River Flood Basalt Province: Geological Society of America Special Paper, v. 497, p. 401-427.

Ferns, M. L., and others, 1993, Geologic map of the Mahogany Mountain $30^{\prime} \times 60^{\prime}$ quadrangle, Malheur County, Oregon and Owyhee County, Idaho: State of Oregon Department of Geology and Mineral Industries GMS-78, scale 1:100,000.

Ferns, M. L., Streck, M. J., \& McClaughry, J. D., 2017, Field-trip guide to Columbia River flood basalts, associated rhyolites, and diverse post-plume volcanism in eastern Oregon (No. 2017-5022-O). US Geological Survey, 30-38 p.

Girard, G., \& Stix, J., 2009, Magma recharge and crystal mush rejuvenation associated with early post-collapse Upper Basin Member rhyolites, Yellowstone caldera, Wyoming: Journal of Petrology, v. 50, p. 2095-2125.

Hagemen, P. L., King, H. D., \& Jones, J. L., 1993, Analytical results and sample locality map of the stream-sediment, heavy-mineral concentrate, and rock samples from the Upper Leslie Gulch (OR-003-074) and Slocum Creek (OR-003-075) Wilderness Study Areas, Malheur County, Oregon: U.S. Geological Survey Open-File Report 93-259-A, $11-22 \mathrm{p}$.

Hooper, P. R., Binger, G. B., \& Lees, K. R., 2002, Ages of the Steens and Columbia River flood basalts and their relationship to extension-related calc-alkalic volcanism in eastern Oregon: Geological Society of America Bulletin, v. 114, p. 43-50. 
Hooper, P. R., Camp, V. E., Reidel, S. P., \& Ross, M. E., 2007, The origin of the Columbia River flood basalt province: Plume versus nonplume models. Geological Society of America Special Papers, v. 430, p. 635-668.

Jordan, B. T., Grunder, A. L., Duncan, R. A., \& Deino, A. L., 2004, Geochronology of age-progressive volcanism of the Oregon High Lava Plains: Implications for the plume interpretation of Yellowstone: Journal of Geophysical Research: Solid Earth, v. 109. doi: https://doi.org/10.1029/2003JB002776

Kurz, G. A., Schmitz, M. D., Northrup, C. J., \& Vallier, T. L., 2017, Isotopic compositions of intrusive rocks from the Wallowa and Olds Ferry arc terranes of northeastern Oregon and western Idaho: Implications for Cordilleran evolution, lithospheric structure, and Miocene magmatism: Lithosphere, v. 9, p. 235-264.

Leeman, W. P., Oldow, J. S., \& Hart, W. K., 1992, Lithosphere-scale thrusting in the western US Cordillera as constrained by $\mathrm{Sr}$ and $\mathrm{Nd}$ isotopic transitions in Neogene volcanic rocks, Geology, v. 20, p. 63-66.

Lipman, P. W., Self, S., \& Heiken, G., 1984, Introduction to Calderas Special Issue: Journal of Geophysical Research: Solid Earth, v. 89, p. 8219-8221.

Mahood, G. A., \& Benson, T. R., 2017, Using ${ }^{40} \mathrm{Ar} /{ }^{39} \mathrm{Ar}$ ages of intercalated silicic tuffs to date flood basalts: Precise ages for Steens Basalt Member of the Columbia River Basalt Group: Earth and Planetary Science Letters, v. 459, p. 340-351. doi: https://doi.org/10.1016/j.epsl.2016.11.038

Marcy, P. I., 2013, Revisiting volcanology and composition of rhyolites and associated REE rich mafic clasts of the Three Fingers caldera, eastern Oregon [M.Sc. thesis]: Portland State University.

McDonough, W. F., \& Sun, S. S., 1995, The composition of the Earth: Chemical Geology, v. 120, p. 223-253.

Reidel, S. P., Camp, V. E., Tolan, T. L., \& Martin, B. S., 2013, The Columbia River flood basalt province: Stratigraphy, areal extent, volume, and physical volcanology. The Columbia River flood basalt province: Geological Society of America Special Paper, v. 497, p. 1-43.

Reidel, S. P., \& Tolan, T. L., 2013, The Grande Ronde Basalt, Columbia River Basalt Group: Geological Society of America Special Papers, v. 497, p. 117-153.

Rytuba, J. J., Vander Meulen, D. B., \& Barlock, V. E., 1991, Tectonic and stratigraphic controls on epithermal precious metal mineralization in the northern part of the Basin and Range, Oregon, Idaho, and Nevada: Geology and ore deposits of the Great Basin —Field Trip Guidebook Compendium, 636-644. 
Rytuba, J. J., Vander Meulen, D. B., \& Raines, G., 1991, Hot-spring precious-metal systems in the Lake Owyhee volcanic field, Oregon-Idaho. In Geology and ore deposits of the Great Basin: Geological Society of Nevada Symposium Proceedings, v. 2, p. 1085 1096.

Rytuba, J. J., 1994, Evolution of volcanic and tectonic features in caldera settings and their importance in localization of ore deposits: Economic Geology, v. 89, p. 1687-1696.

Sun, S. S., \& McDonough, W. F., 1989, Chemical and isotopic systematics of oceanic basalts: implications for mantle composition and processes: Geological Society, London, Special Publications, v. 42, p. 313-345.

Streck, M.J., and Grunder, A.L., 1997, Compositional gradients and gaps in high-silica rhyolites of the Rattlesnake Tuff, Oregon: Journal of Petrology, v. 38, no. 1, p. 133-163.

Streck, M. J., \& Grunder, A. L., 2008, Phenocryst-poor rhyolites of bimodal, tholeiitic provinces: the Rattlesnake Tuff and implications for mush extraction models: Bulletin of Volcanology, v. 70, p. 385-401.

Streck, M. J., Ferns, M. L., \& McIntosh, W., 2015, Large, persistent rhyolitic magma reservoirs above Columbia River Basalt storage sites: The Dinner Creek Tuff eruptive center, eastern Oregon: Geosphere, v. 11, p. 226-235. doi:

https://doi.org/10.1130/GES01086.1

Sun, S. S., \& McDonough, W. F., 1989, Chemical and isotopic systematics of oceanic basalts: implications for mantle composition and processes: Geological Society, London, Special Publications, v. 42, p. 313-345.

Sweeten, R. A., 2020, Stratigraphy of the Tuff of Leslie Gulch: Implications for eruptive processes and style during the formation of the Mahogany Mountain Caldera [B.Sc. thesis]: Portland State University.

Tumpane, K. P., 2010, Age and isotopic investigations of the Olds Ferry terrane and its relations to other terranes of the Blue Mountains province, eastern Oregon and westcentral Idaho [M.Sc. thesis]: Boise State University.

Webb, B. M., Streck, M. J., McIntosh, W. C., \& Ferns, M. L., 2018, The Littlefield Rhyolite and associated mafic lavas: Bimodal volcanism of the Columbia River magmatic province, with constraints on age and storage sites of Grande Ronde Basalt magmas: Geosphere, v. 15, p. 60-84. doi: https://doi.org/10.1130/GES01695.1

Whalen, J. B., Currie, K. L., \& Chappell, B. W., 1987, A-type granites: geochemical characteristics, discrimination and petrogenesis: Contributions to mineralogy and petrology, v. 95, p. 407-419. 
Wolff, J. A., Ramos, F. C., Hart, G. L., Patterson, J. D., \& Brandon, A. D., 2008, Columbia River flood basalts from a centralized crustal magmatic system: Nature geoscience, v. 1, p. 177.

Wolff, J. A., Ramos, F. C., Reidel, S. P., Camp, V. E., Ross, M. E., Martin, B. S., ... \& Wells, R. E. (2013). Source materials for the main phase of the Columbia River Basalt Group: Geochemical evidence and implications for magma storage and transport. The Columbia River Flood Basalt Province: Geological Society of America Special Paper, v. 497, p. 273-291.

Vander Meulen, D. B., 1989, Intracaldera tuffs and central-vent intrusion of the Mahogany Mountain caldera, eastern Oregon: US Geological Survey Open File Report 89-77, doi: https://doi.org/10.3133/ofr8977 


\section{APPENDIX A: ${ }^{40} \mathrm{Ar} /{ }^{39} \mathrm{Ar}$ DATING OF RHYOLITE LAVAS}

Sample preparation for total fusion ${ }^{40} \mathrm{Ar} /{ }^{39} \mathrm{Ar}$ age dating of rhyolite lava samples of this study were initiated at Portland state University, and then completed at Oregon State University's Geochronology Laboratory. Sample preparation began with, crushing sample material in a Braun Chipmunk to reduce material size to a range of fine gravel to sand. The resultant material is sieved, to isolate the largest size fraction containing whole sanidine crystals. The best range of material was found to be 850-355 microns. The resultant whole sanidine crystals were washed with deionized water to remove fine debris. The crystals were then processed with a Frantz magnetic separator to remove all magnetic minerals and crystals with ferrous inclusions. The magnetic separator was set to 1.75A non-mag. The resultant crystals were then leached in $15 \% \mathrm{HF}$ in order to dissolve glass / groundmass grains, and to dissolve any groundmass attached to sanidine grains. This was performed by pouring $15 \%$ HF into plastic beakers and putting them into an ultrasonic water bath for 6 minutes. The samples were rinsed with deionized water, dried, and re-sieved to remove fines. No heavy-liquid separation was necessary, because all the feldspars in the separates were identified to be sanidine using petrographic methods. This was also verified by viewing small amounts of the separates in wintergreen oil, confirming the feldspar composition as an alkali feldspar. The crystals were then packaged in aluminum capsules for irradiation. Irradiation was conducted for 6 hours, and subsequently sample material was left to cool for two weeks prior to analysis.

Total fusion ${ }^{40} \mathrm{Ar} /{ }^{39} \mathrm{Ar}$ age dates for 4 rhyolite samples were performed at the Oregon State University's Geochronology Laboratory under the supervision of Dan Miggins. The resulting age determinations are relative to the Fish Canyon Tuff (28.201) sanidine monitors. A summary of the results is provided below. Detailed results are shown in the pages that follow.

Weighted plateau ages are preferred over inverse isochron ages based on the weighted mean of ${ }^{39} \mathrm{Ar}(\%)$, providing a more reliable age estimate that is less susceptible to alteration and fluctuations of ${ }^{39}$ Ar within the crystal framework. The weighted plateau is produced through step heating of a group of feldspar crystals for that sample.

Temperature is increased as heating continues, producing variable amounts of ${ }^{39} \mathrm{Ar}$ 
released from the outer shells of the crystal framework moving inward with continued heating. Once the amounts of ${ }^{39} \mathrm{Ar}(\%)$ begin to return with some consistency, these steps are measured and summed to give more reliable estimations of age based on the 'plateau' and number of steps, produced through step heating of that sample. Whereas inverse isochron ages are determined by off gassing of ${ }^{39} \mathrm{Ar}$ from individual crystals and plotted to give a mean age based on the variability of individual crystals.

\section{APPENDIX A: ${ }^{40}$ Ar $/{ }^{39}$ Ar DATING OF RHYOLITE LAVAS}

Table 15. Total fusion ${ }^{40} \mathrm{Ar} /{ }^{39} \mathrm{Ar}$ dates for the 'Rhyolite SE of Round Mt.', the Mahogany Mt. rhyolite suite, and the McCain Creek rhyolite.

\begin{tabular}{|c|c|c|c|c|c|c|c|c|c|c|}
\hline \multirow[b]{2}{*}{$\begin{array}{c}\text { Sample } \\
\text { ID }\end{array}$} & \multirow[b]{2}{*}{ Unit } & \multirow[b]{2}{*}{$\begin{array}{c}\text { Material } \\
\text { Dated }\end{array}$} & \multicolumn{4}{|c|}{ Plateau } & \multirow{2}{*}{$\begin{array}{l}\text { Weighted } \\
\text { Plateau } \\
\text { MSWD }\end{array}$} & \multicolumn{3}{|c|}{ Isochron } \\
\hline & & & $\begin{array}{l}\text { Age } \\
\text { (Ma) }\end{array}$ & $\pm 2 \sigma$ & $\begin{array}{c}\text { Steps } \\
\text { Plateau } \\
(\mathbf{n})\end{array}$ & $\begin{array}{l}{ }^{39} \mathrm{Ar} \\
(\%)\end{array}$ & & $\begin{array}{c}\text { Age } \\
\text { (Ma) }\end{array}$ & $\pm 2 \sigma$ & $\begin{array}{c}\text { Isochron } \\
\text { MSWD }\end{array}$ \\
\hline RJ-18-05 & $\begin{array}{c}\text { Rhyolite } \\
\text { SE of } \\
\text { Round } \\
\text { Mtn }\end{array}$ & Sanidine & $\begin{array}{c}15.8 \\
3\end{array}$ & \pm 0.04 & 27 & $\begin{array}{c}90.3 \\
6\end{array}$ & 4.84 & 15.84 & \pm 0.04 & 4.95 \\
\hline RJ-18-11 & $\begin{array}{l}\mathrm{MMr}- \\
\text { Flow } 1\end{array}$ & Plag. & $\begin{array}{c}15.8 \\
1\end{array}$ & \pm 0.06 & 23 & 76.2 & 5.27 & 15.77 & \pm 0.06 & 5.54 \\
\hline RJ-18-50 & $\begin{array}{l}\mathrm{MMr}- \\
\text { Flow } 2\end{array}$ & Sanidine & $\begin{array}{c}15.8 \\
2\end{array}$ & \pm 0.05 & 25 & $\begin{array}{c}86.8 \\
7\end{array}$ & 4.70 & 15.80 & \pm 0.05 & 5.52 \\
\hline RJ-18-03 & $\begin{array}{l}\text { MMr - } \\
\text { Flow } 3\end{array}$ & Sanidine & $\begin{array}{c}15.7 \\
1\end{array}$ & \pm 0.05 & 26 & $\begin{array}{c}100 . \\
0\end{array}$ & 2.54 & 15.70 & \pm 0.05 & 1.87 \\
\hline RJ-18-57 & $\begin{array}{c}\text { McCain } \\
\text { Creek } \\
\text { Rhyolite }\end{array}$ & Sanidine & $\begin{array}{c}14.4 \\
2\end{array}$ & \pm 0.04 & 26 & $\begin{array}{c}89.2 \\
9\end{array}$ & 8.58 & 14.40 & \pm 0.05 & 16.22 \\
\hline
\end{tabular}




\section{APPENDIX A: ${ }^{40} \mathrm{Ar} /{ }^{39} \mathrm{Ar}$ DATING OF RHYOLITE LAVAS}

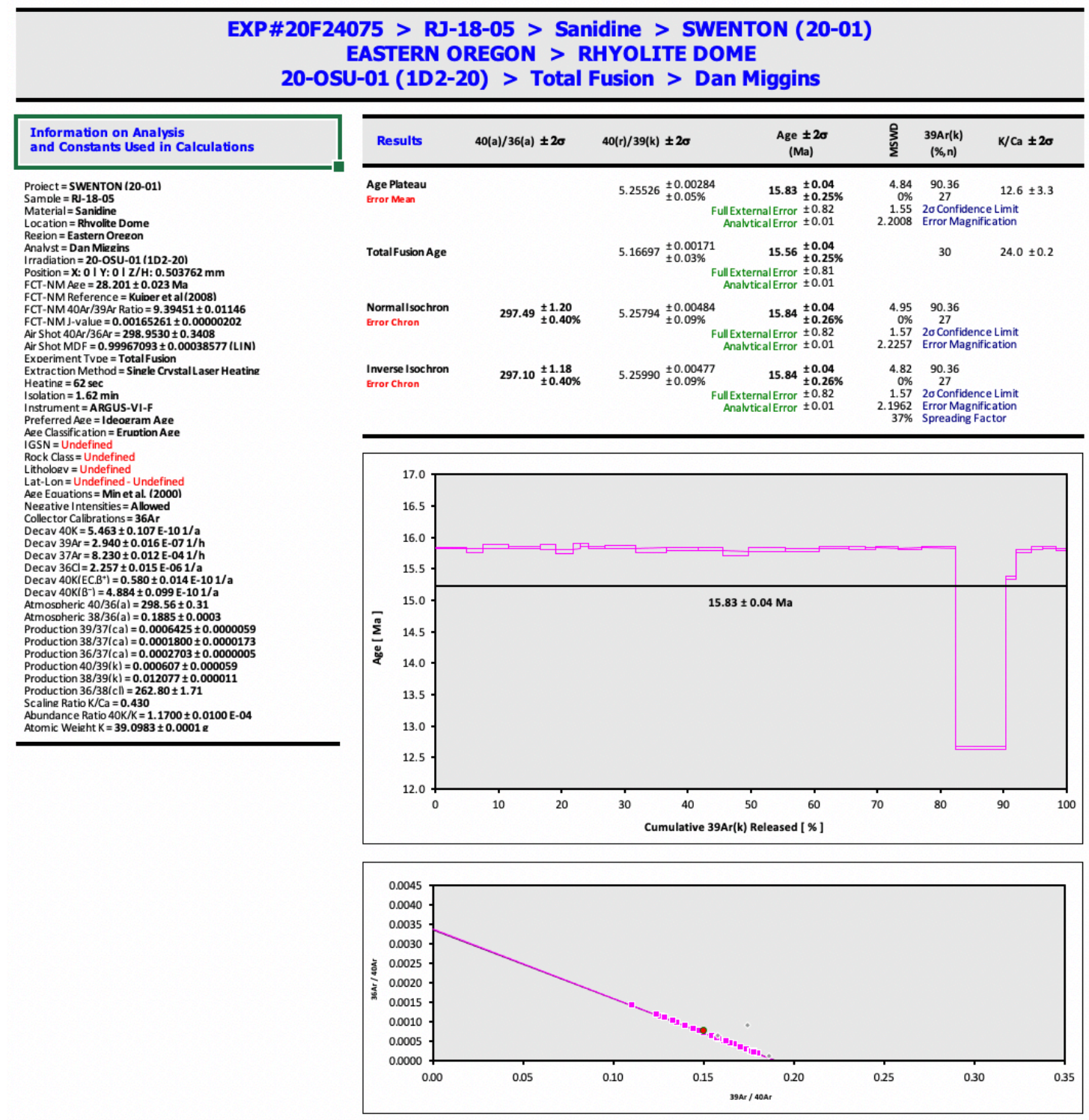

Figure 62. Total fusion ${ }^{40} \mathrm{Ar} /{ }^{39} \mathrm{Ar}$ age dating of 'Rhyolite SE of Round Mtn', sample RJ-18-05. 


\section{APPENDIX A: ${ }^{40}$ Ar $/{ }^{39}$ Ar DATING OF RHYOLITE LAVAS}

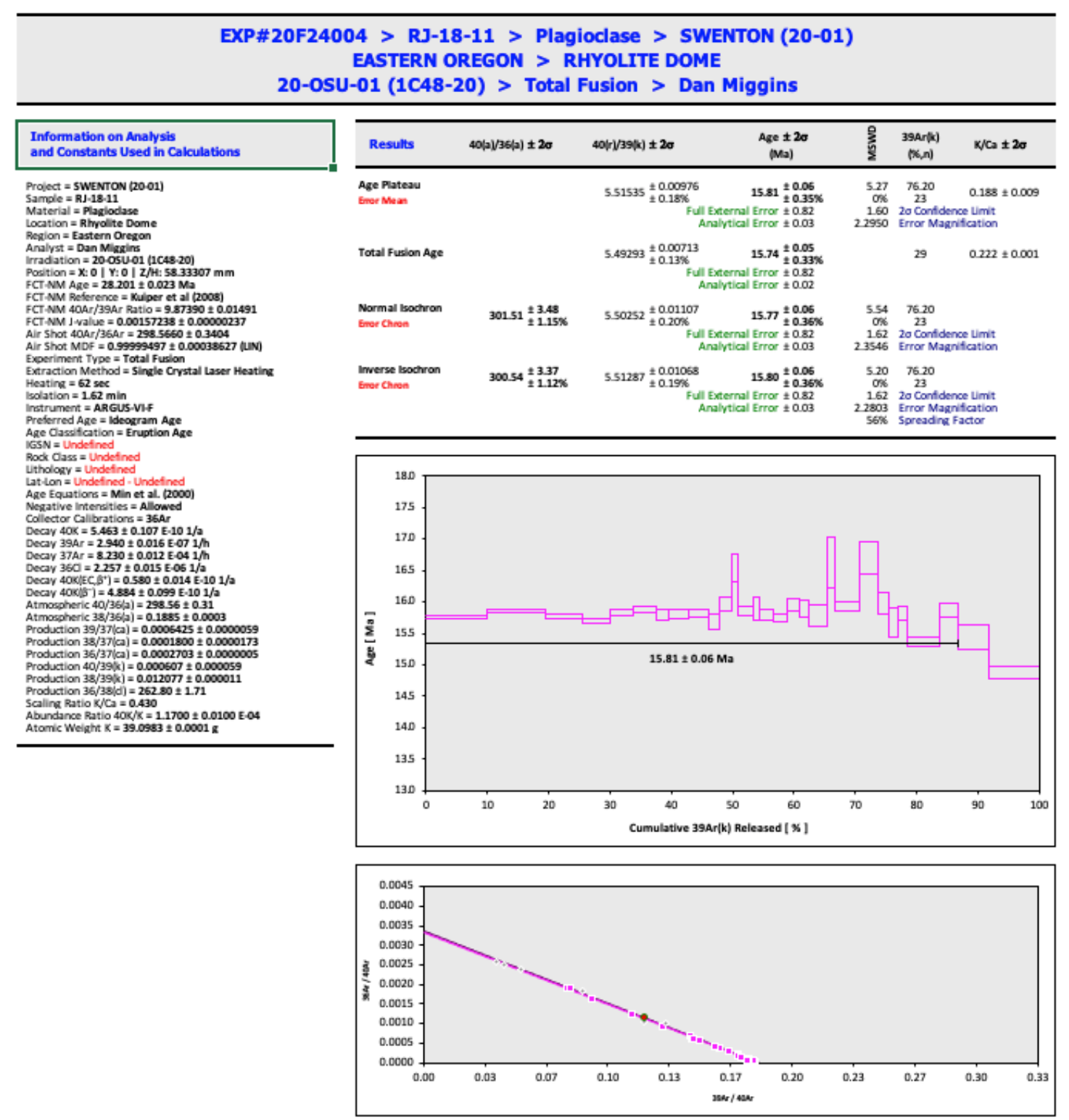

Figure 63. Total fusion ${ }^{40} \mathrm{Ar} /{ }^{39} \mathrm{Ar}$ age dating of Mahogany Mountain Rhyolite flow unit 1, sample RJ-18-11. 


\section{APPENDIX A: ${ }^{40} \mathrm{Ar} /{ }^{39} \mathrm{Ar}$ DATING OF RHYOLITE LAVAS}
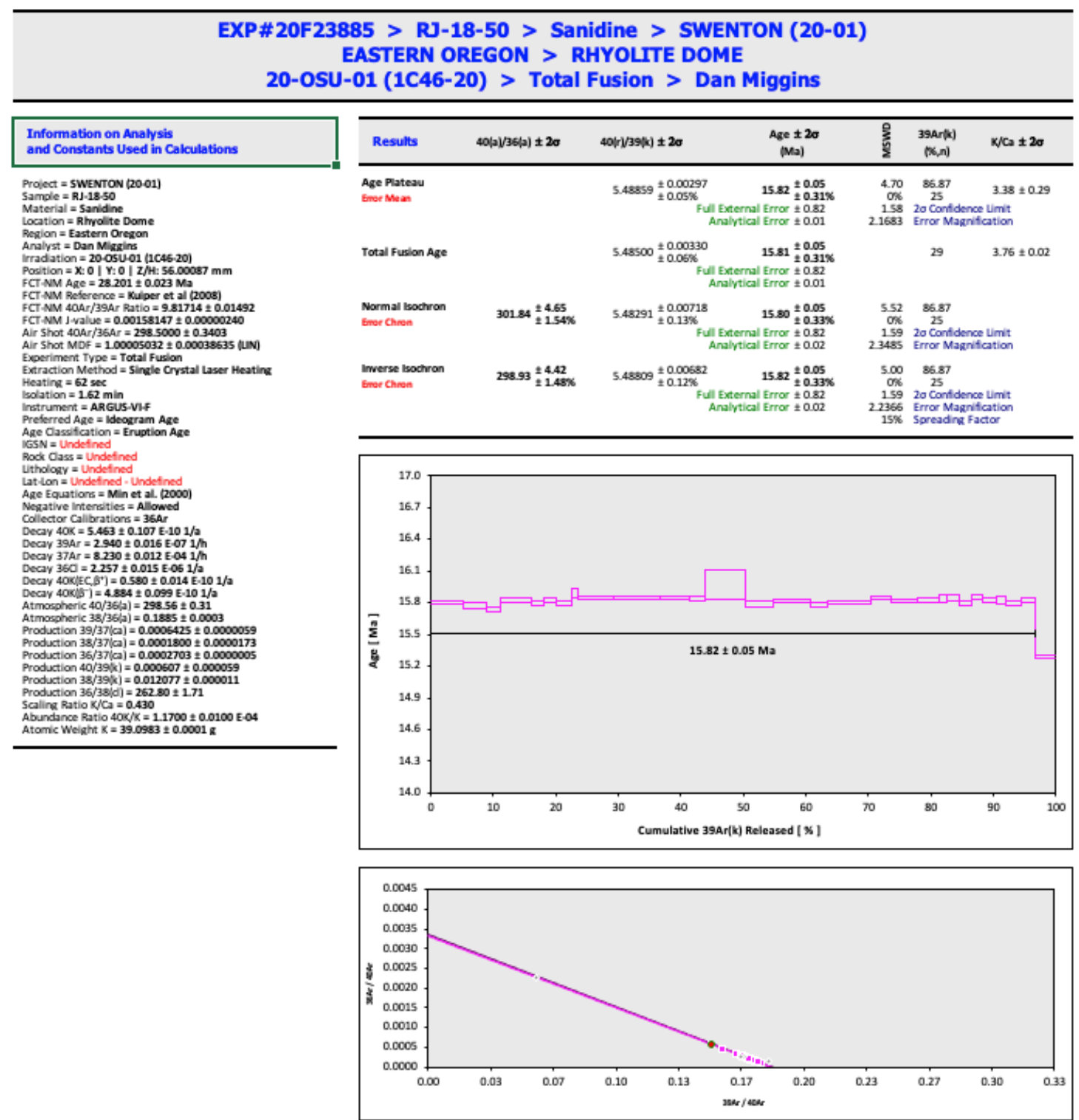

Figure 64. Total fusion ${ }^{40} \mathrm{Ar} /{ }^{39} \mathrm{Ar}$ age dating of Mahogany Mountain Rhyolite Flow unit 2, sample RJ-18-50. 


\section{APPENDIX A: ${ }^{40}$ Ar $/{ }^{39}$ Ar DATING OF RHYOLITE LAVAS}

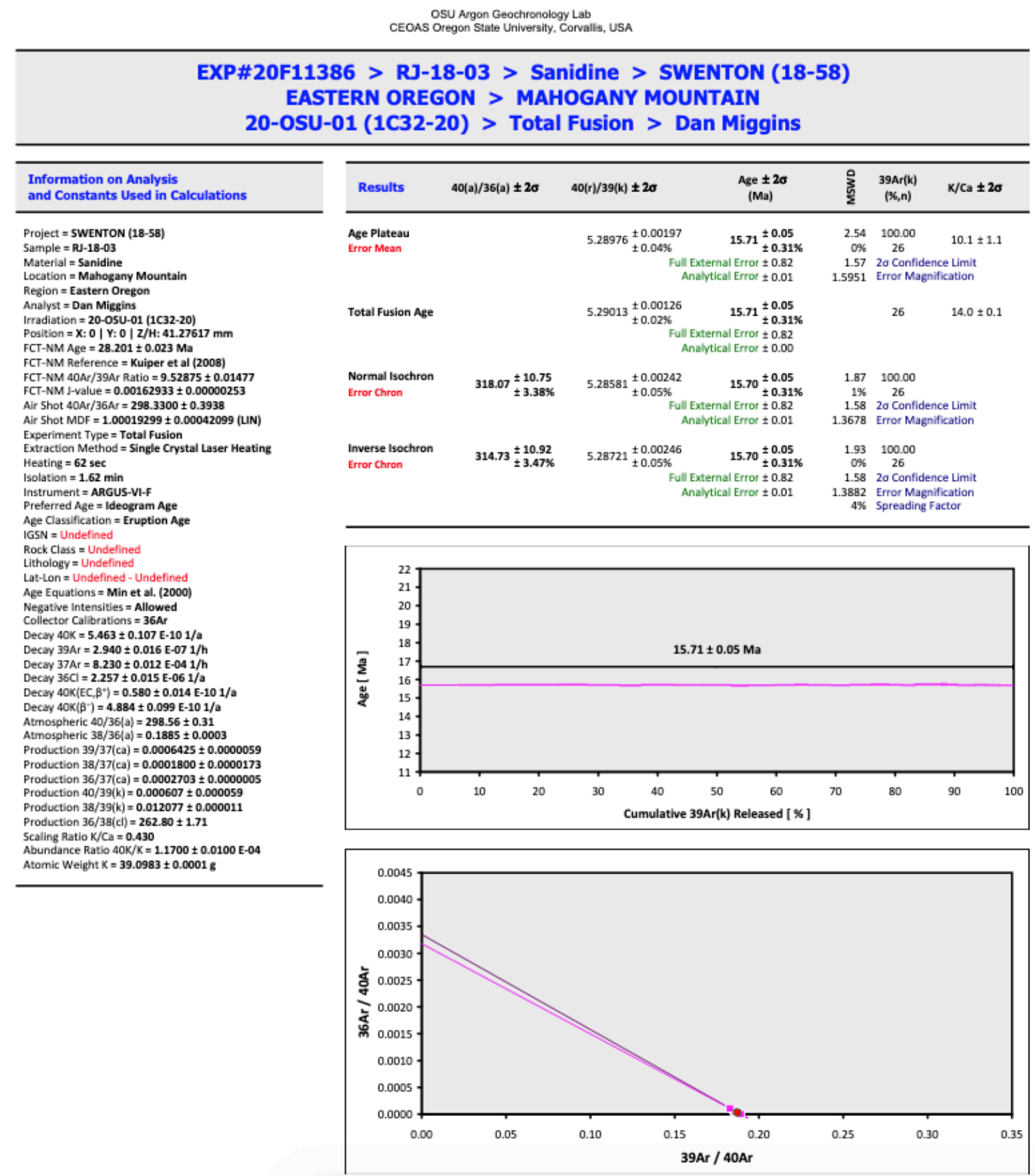

Figure 65. Total fusion ${ }^{40} \mathrm{Ar} /{ }^{39} \mathrm{Ar}$ age dating of Mahogany Mountain Rhyolite Flow unit 3, sample RJ-18-03. 


\section{APPENDIX A: ${ }^{40} \mathrm{Ar} /{ }^{39} \mathrm{Ar}$ DATING OF RHYOLITE LAVAS}

\section{EXP\#20F23212 > RJ-18-57 > Sanidine > SWENTON (20-01) EASTERN OREGON > RHYOLITE DOME \\ 20-0SU-01 (1C38-20) > Total Fusion > Dan Miggins}

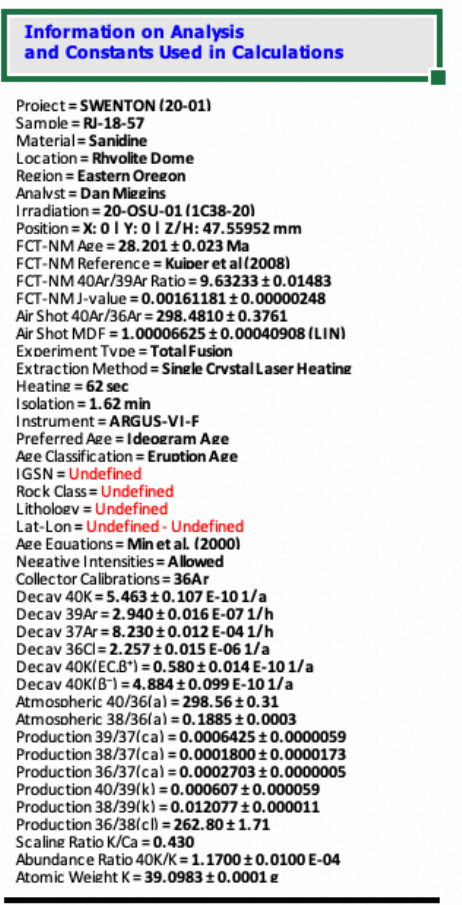

\begin{tabular}{|c|c|c|c|c|c|c|}
\hline Results & $40(a) / 36(a) \pm 2 \sigma$ & $40(r) / 39(k) \pm 2 \sigma$ & $\begin{array}{l}\text { Age } \pm 2 \sigma \\
\text { (Ma) }\end{array}$ & $\sum_{\text {ñ }}^{p}$ & $\begin{array}{l}\text { 39Ar(k) } \\
(\%, n)\end{array}$ & $\mathrm{k} / \mathrm{Ca} \pm 2 \sigma$ \\
\hline $\begin{array}{l}\text { Age Plateau } \\
\text { Error Mean }\end{array}$ & & 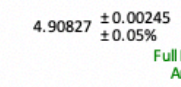 & $\begin{array}{l}\text { Full External Error } \pm 0.75 \\
\text { Analutical Error } \pm 0.01\end{array}$ & $\begin{array}{r}8.58 \\
0 \% \\
1.57 \\
2.9299\end{array}$ & \multicolumn{2}{|c|}{$\begin{array}{l}2 \sigma \text { Confidence Limit } \\
\text { Error Magnification }\end{array}$} \\
\hline TotalFusion Age & \multicolumn{6}{|c|}{$\begin{array}{r}\text { Full External Error } \pm 0.75 \\
\text { Analvicical Error } \pm 0.00\end{array}$} \\
\hline $\begin{array}{l}\text { Normall sochron } \\
\text { Error Chron }\end{array}$ & $347.66 \stackrel{ \pm 37.69}{ \pm 10.84 \%}$ & $4.89934 \begin{array}{r} \pm 0.00526 \\
\pm 0.11 \% \\
\text { Full }\end{array}$ & $\begin{array}{l}14.40 \pm 0.05 \\
\pm 0.32 \% \\
\text { al Error } \pm 0.75 \\
\text { al Error } \pm 0.02\end{array}$ & $\begin{array}{r}16.22 \\
0 \% \\
1.58 \\
4.0278\end{array}$ & \multicolumn{2}{|c|}{$\begin{array}{l}89.29 \\
26 \\
\text { 20 Confidence Limit } \\
\text { Error Magnification }\end{array}$} \\
\hline $\begin{array}{l}\text { Inverse Isochron } \\
\text { Error Chron }\end{array}$ & $302.62 \begin{array}{l} \pm 27.28 \\
\pm 9.02 \%\end{array}$ & $\begin{aligned} & 4.90787 \pm 0.00385 \\
& \pm 0.08 \% \\
& \text { Full }\end{aligned}$ & $\begin{array}{l}14.42 \pm 0.05 \\
\pm 0.32 \% \\
\text { al Error } \pm 0.75 \\
\text { al Error } \pm 0.01\end{array}$ & $\begin{array}{r}8.91 \\
0 \% \\
1.58 \\
2.9854 \\
2 \%\end{array}$ & \multicolumn{2}{|c|}{$\begin{array}{l}89.29 \\
26 \\
2 \sigma \text { Confidence Limit } \\
\text { Error Magnification } \\
\text { Spreading Factor }\end{array}$} \\
\hline
\end{tabular}
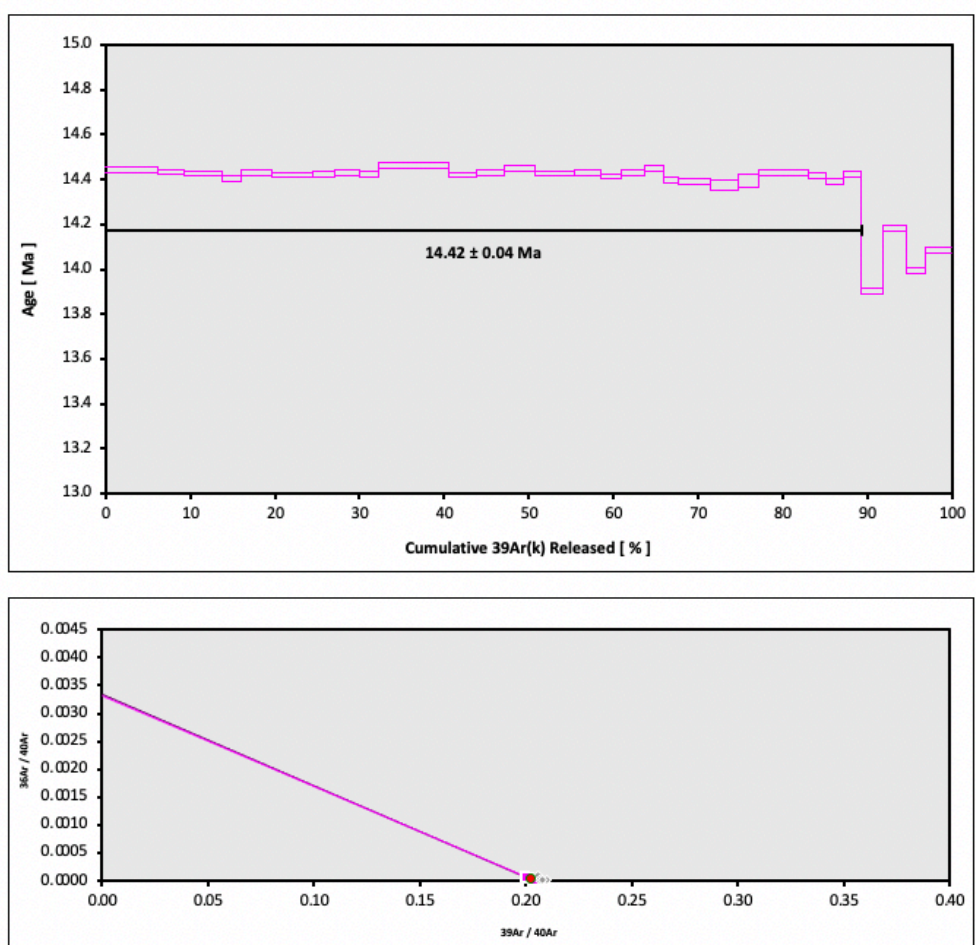

Figure 66. Total fusion ${ }^{40} \mathrm{Ar} /{ }^{39} \mathrm{Ar}$ age dating of McCain Creek Rhyolite lava, sample RJ-18-57. 


\section{APPENDIX B: Thin Sections of Rhyolite Units}

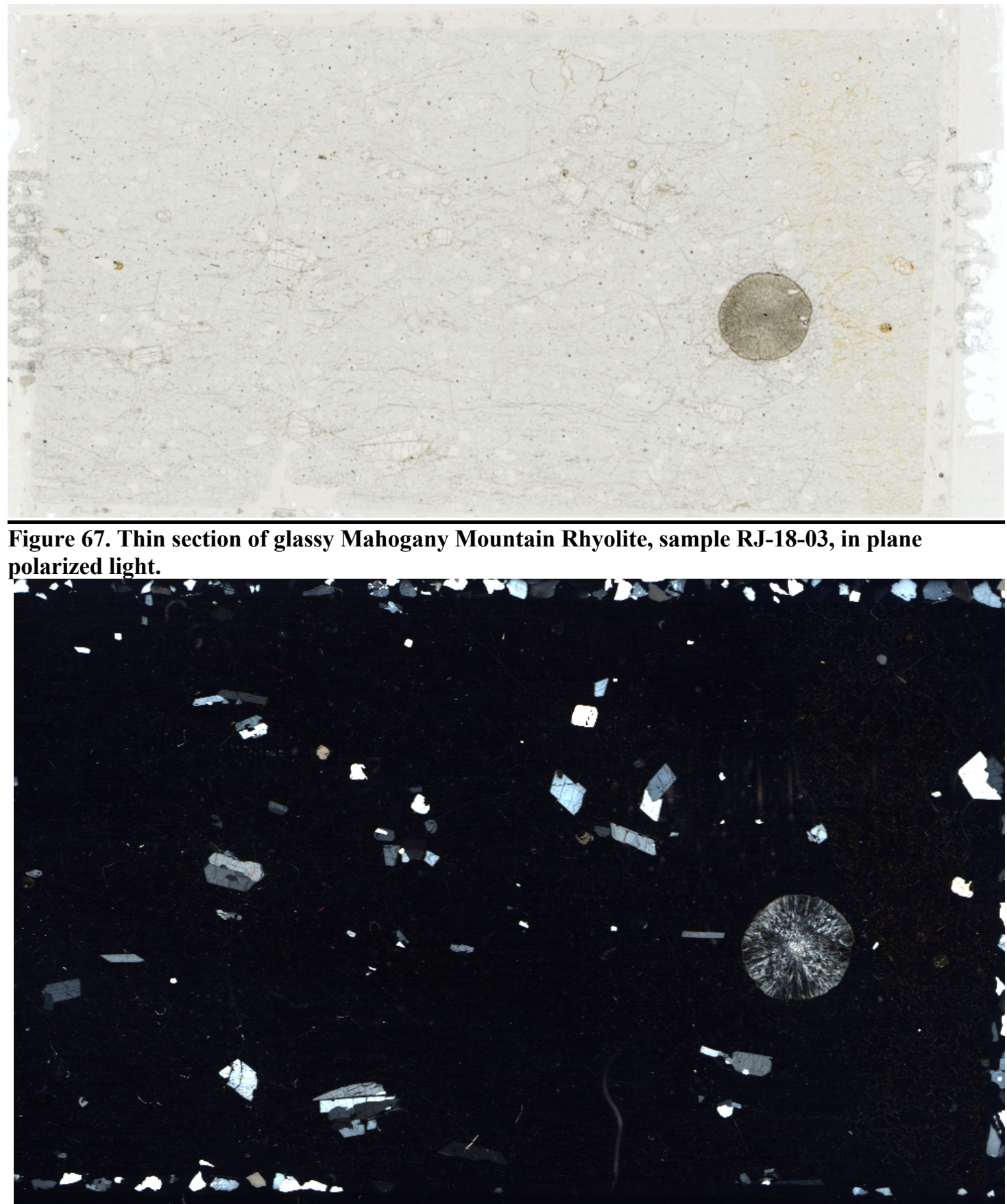

Figure 68. Thin section of glassy Mahogany Mountain Rhyolite, sample RJ-18-03, in cross polarized light. 
APPENDIX B: Thin Sections of Rhyolite Units

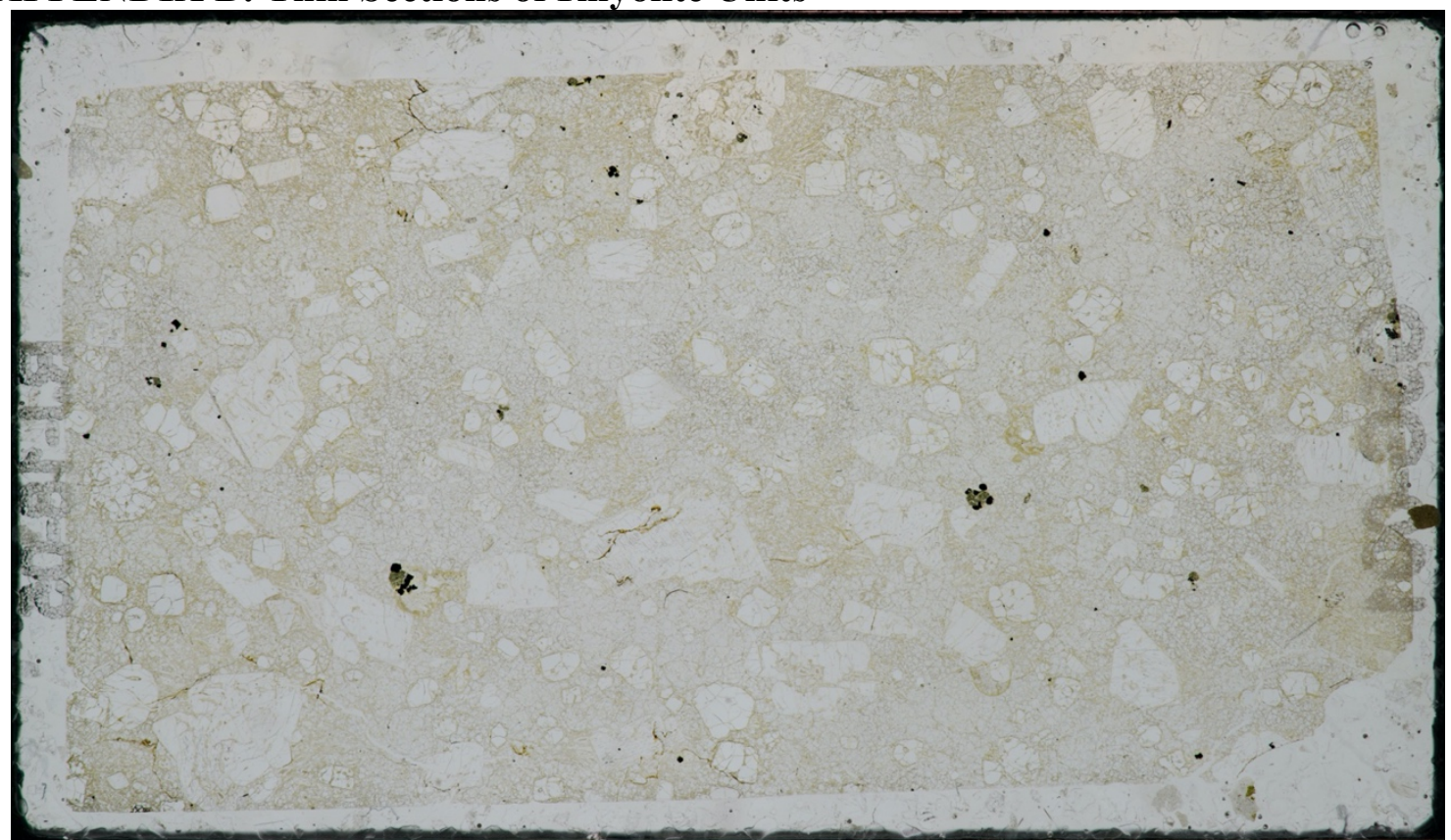

Figure 69. Thin section of 'Rhyolite SE of Round Mtn', sample RJ-18-05, in plane polarized light.

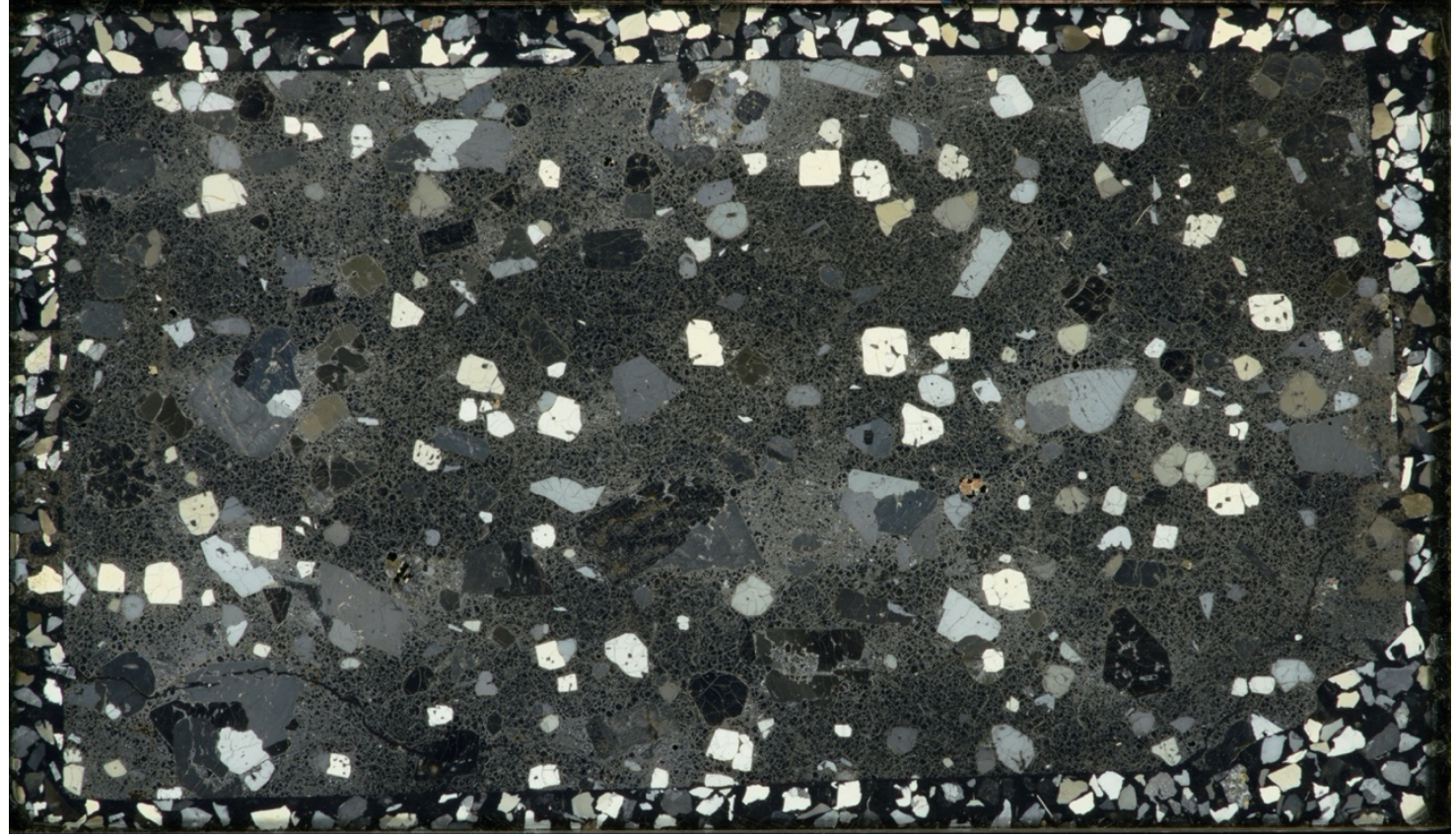

Figure 70. Thin section of 'Rhyolite SE of Round Mtn', sample RJ-18-05, in cross polarized light. 
APPENDIX B: Thin Sections of Rhyolite Units

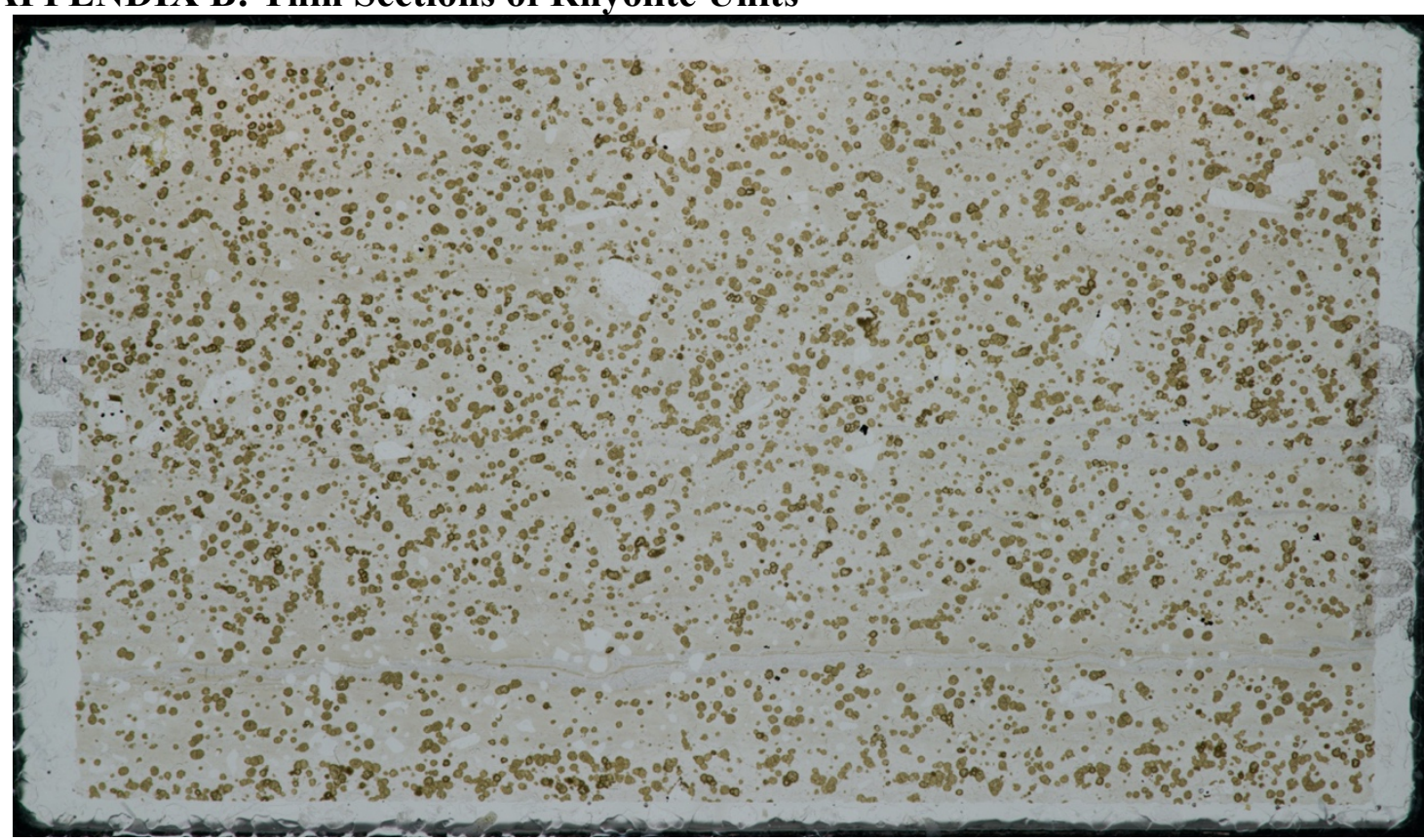

Figure 71. Thin section of Mahogany Mountain rhyolite Flow unit 1, sample RJ-18-11, in plane polarized light.

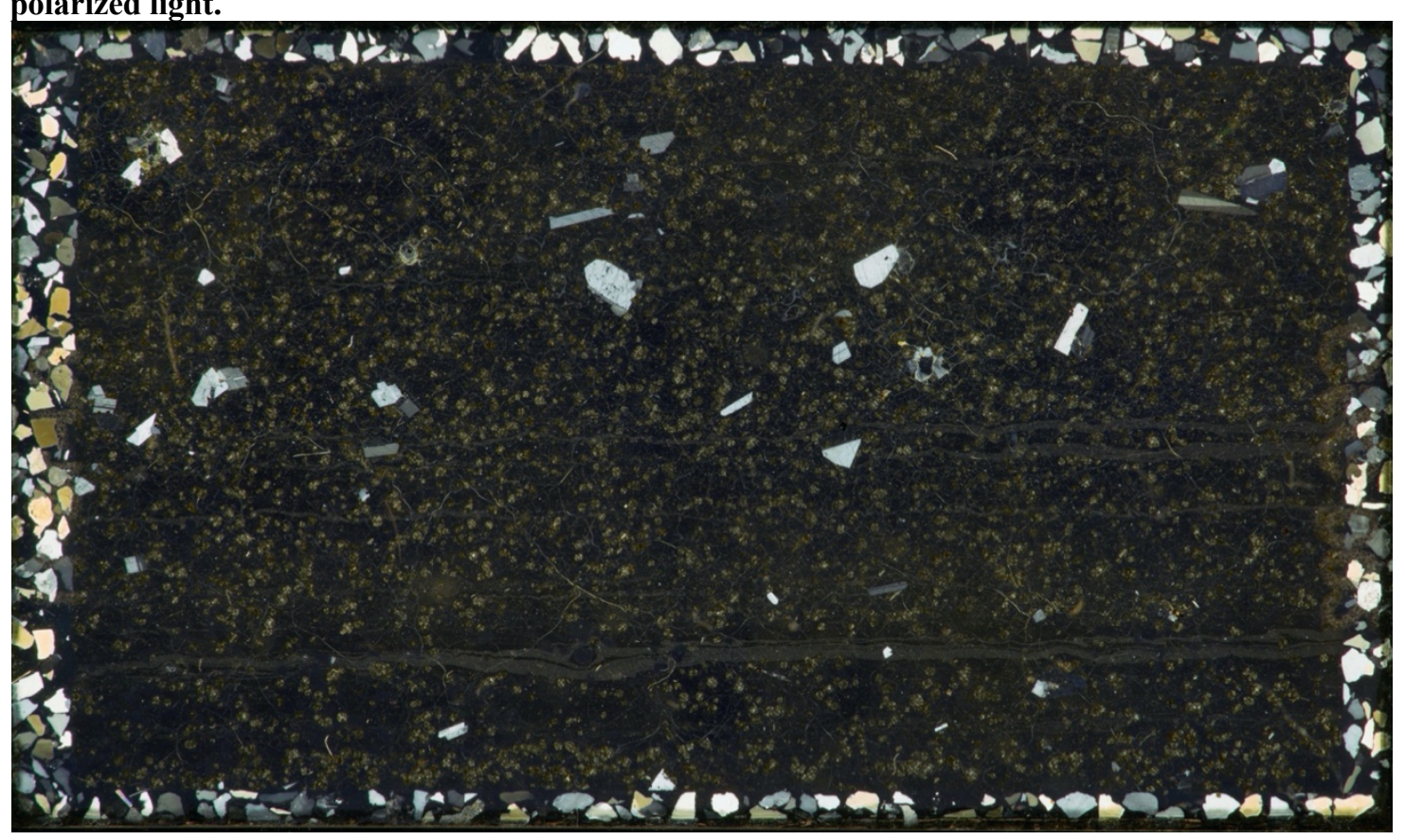

Figure 72. Thin section of glassy Mahogany Mountain rhyolite Flow unit 1, sample RJ-18-11, in cross polarized light. 


\section{APPENDIX B: Thin Sections of Rhyolite Units}

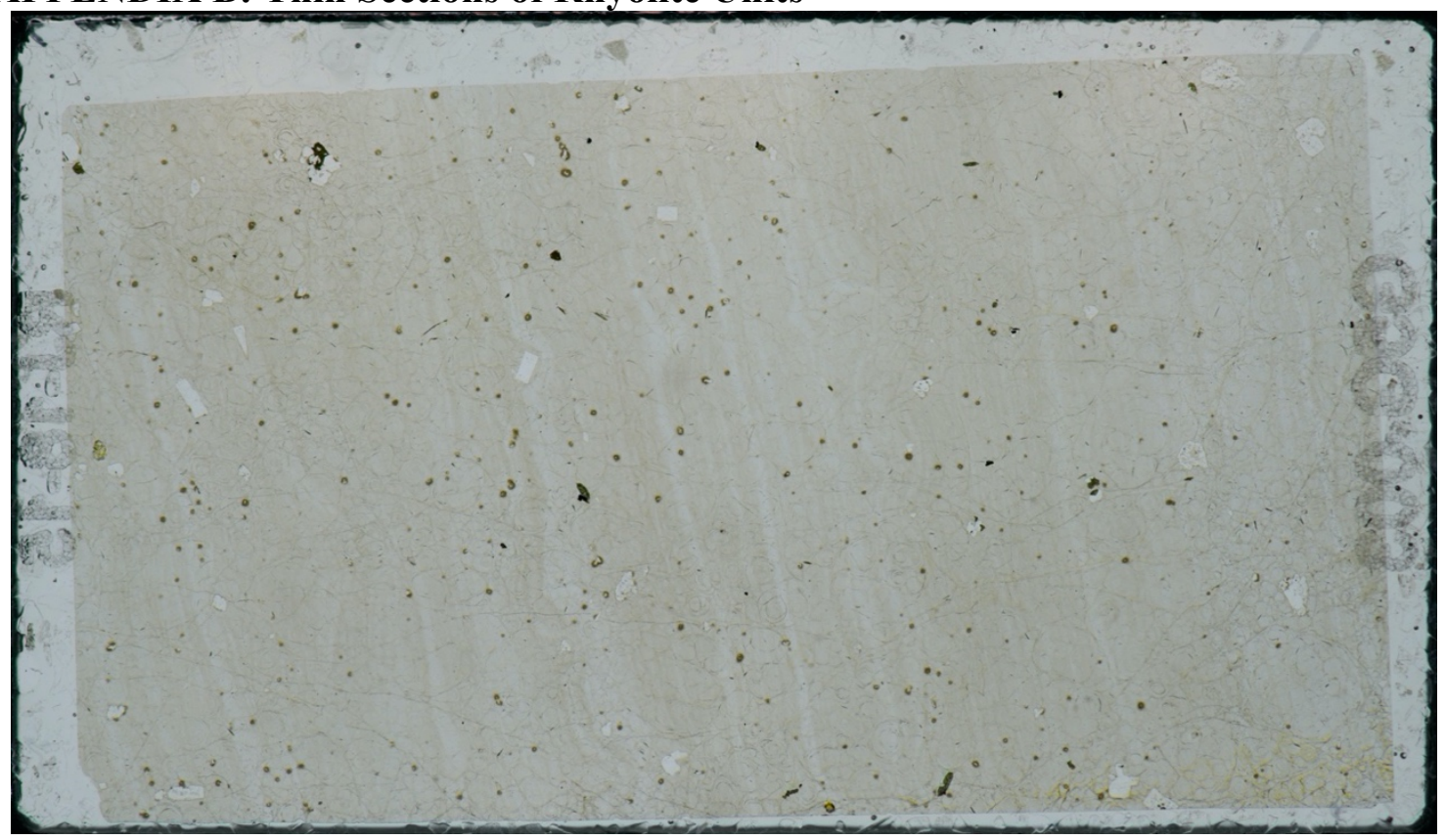

Figure 73. Thin section of glassy Bannock Ridge rhyolite, sample RJ-18-15, in plane polarized light.

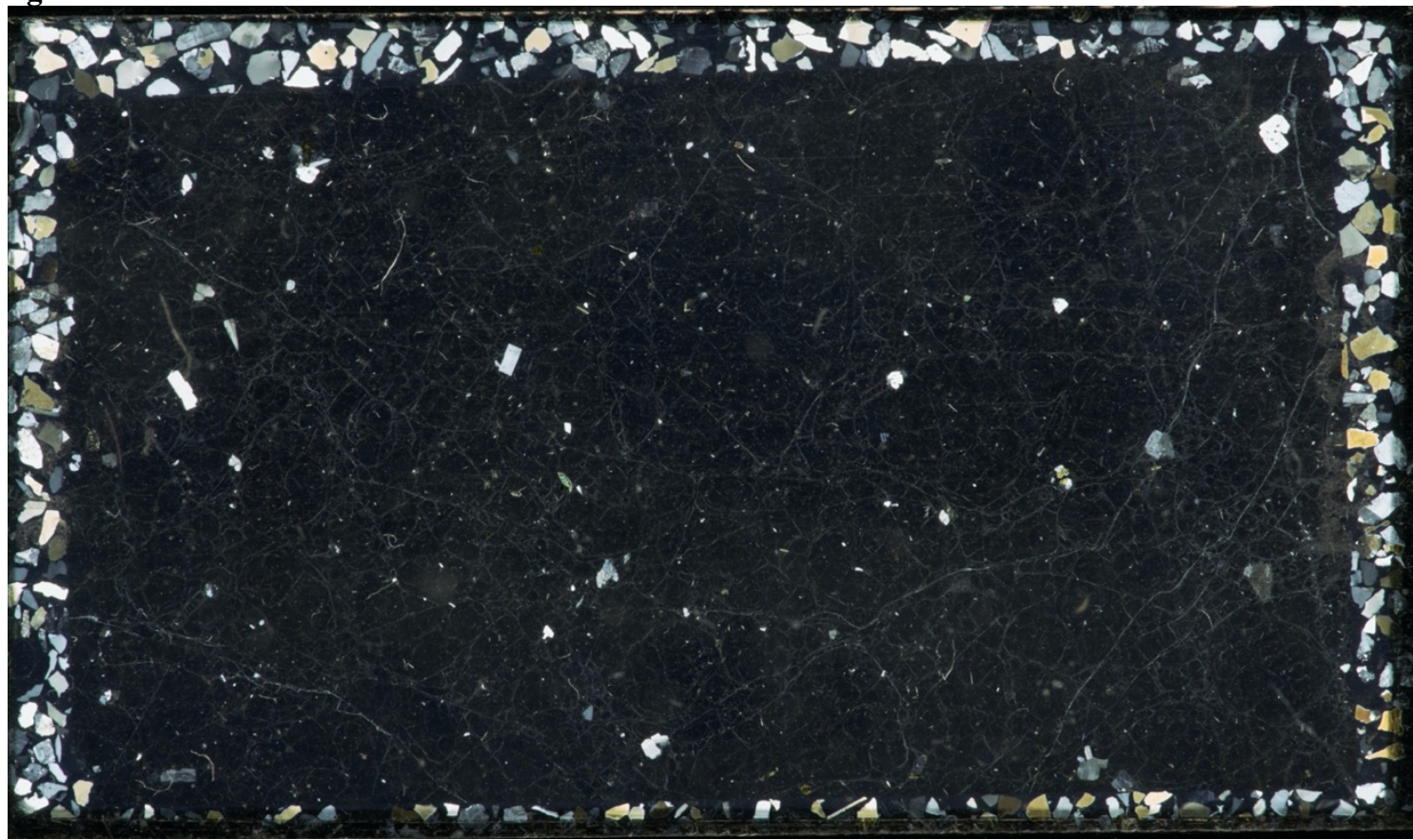

Figure 74. Thin section of glassy Bannock Ridge rhyolite, sample RJ-18-15, in cross polarized light. 
Figure 75. Thin section of glassy Mahogany Mountain rhyolite Flow unit 3, sample RJ-18-19, in plane polarized light.

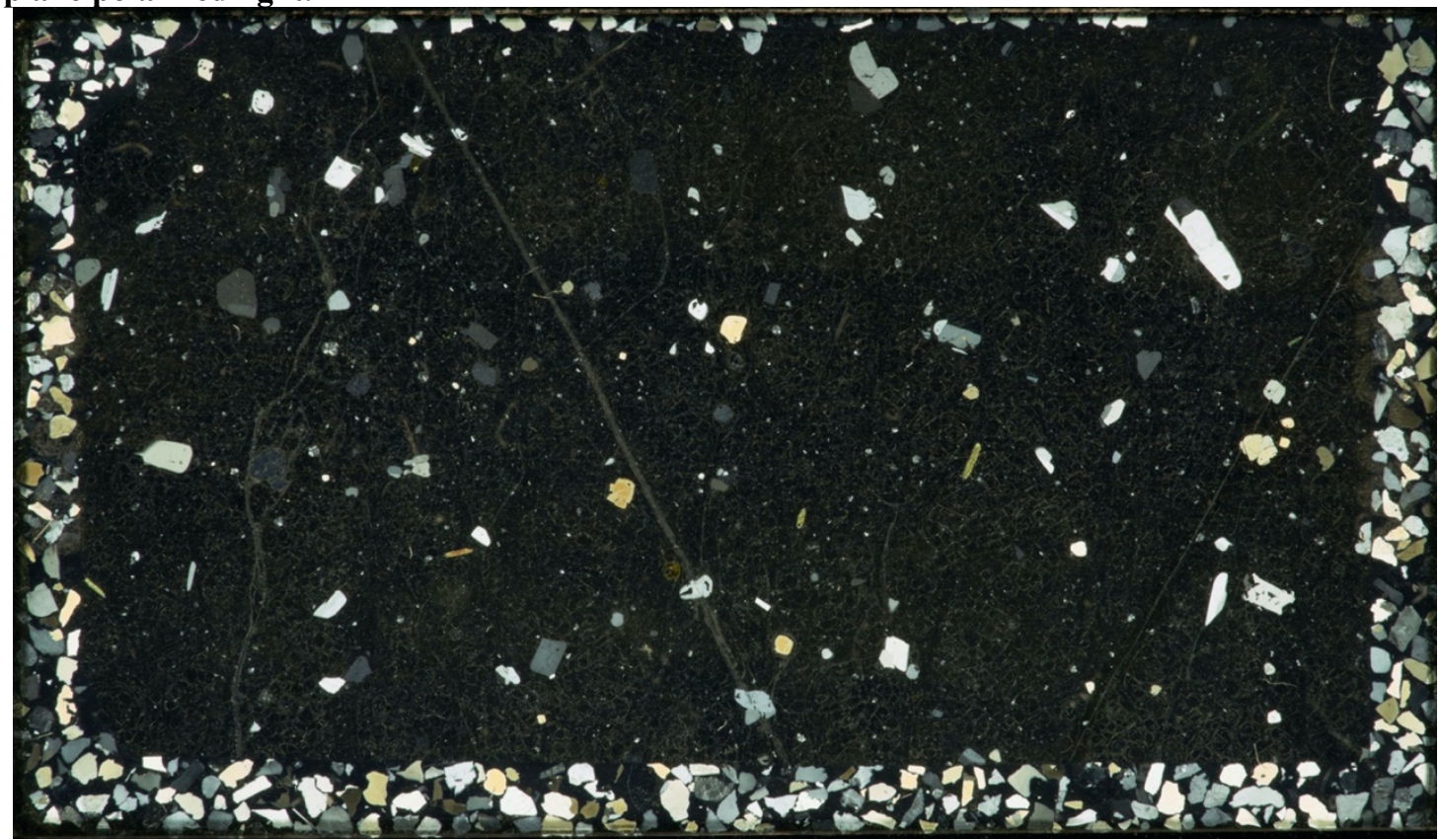

Figure 76. Thin section of glassy Mahogany Mountain rhyolite Flow unit 3, sample RJ-18-19, in cross polarized light. 
APPENDIX B: Thin Sections of Rhyolite Units

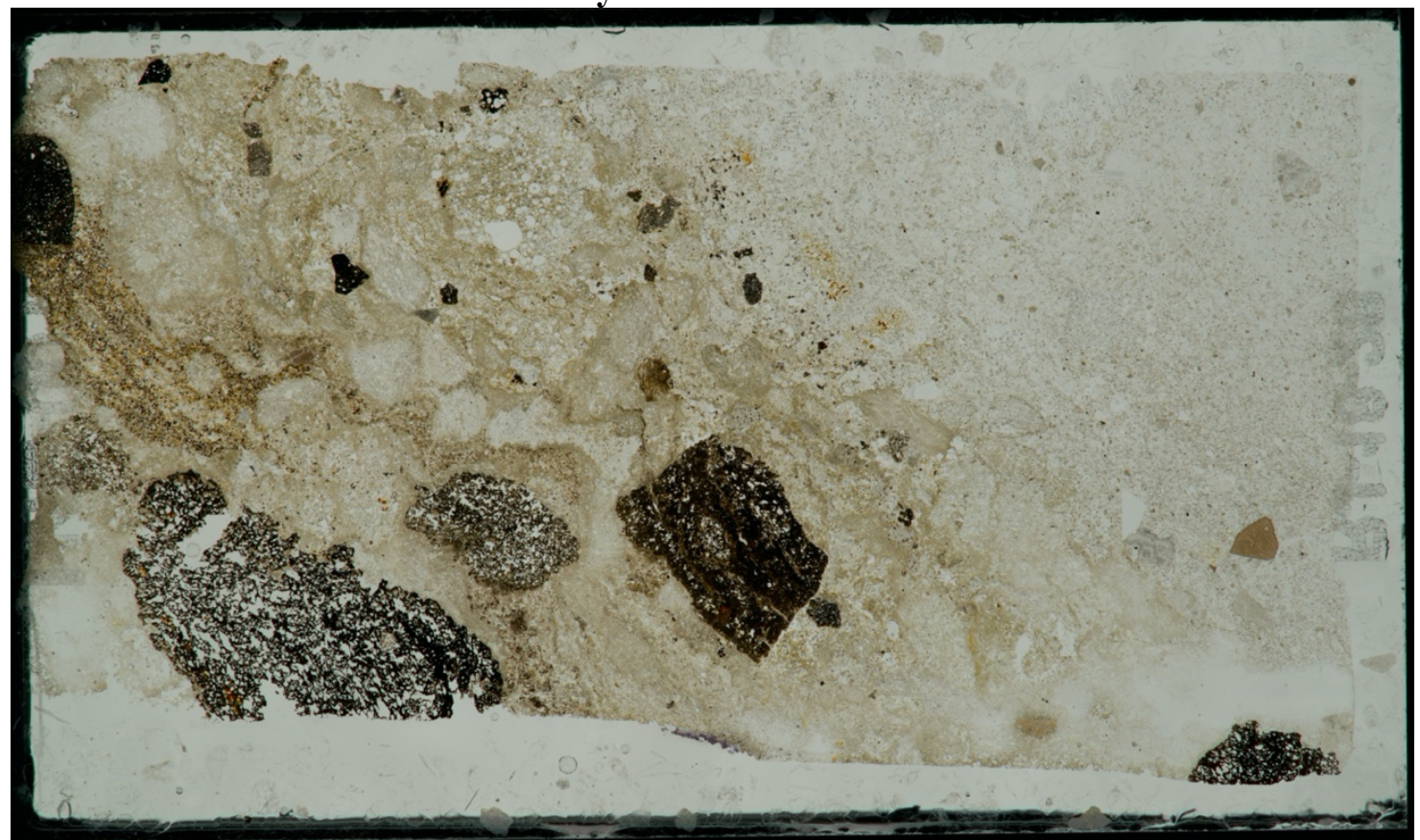

Figure 77. Thin section of Leslie Gulch ash-flow tuff, sample RJ-18-28, in plane polarized light.

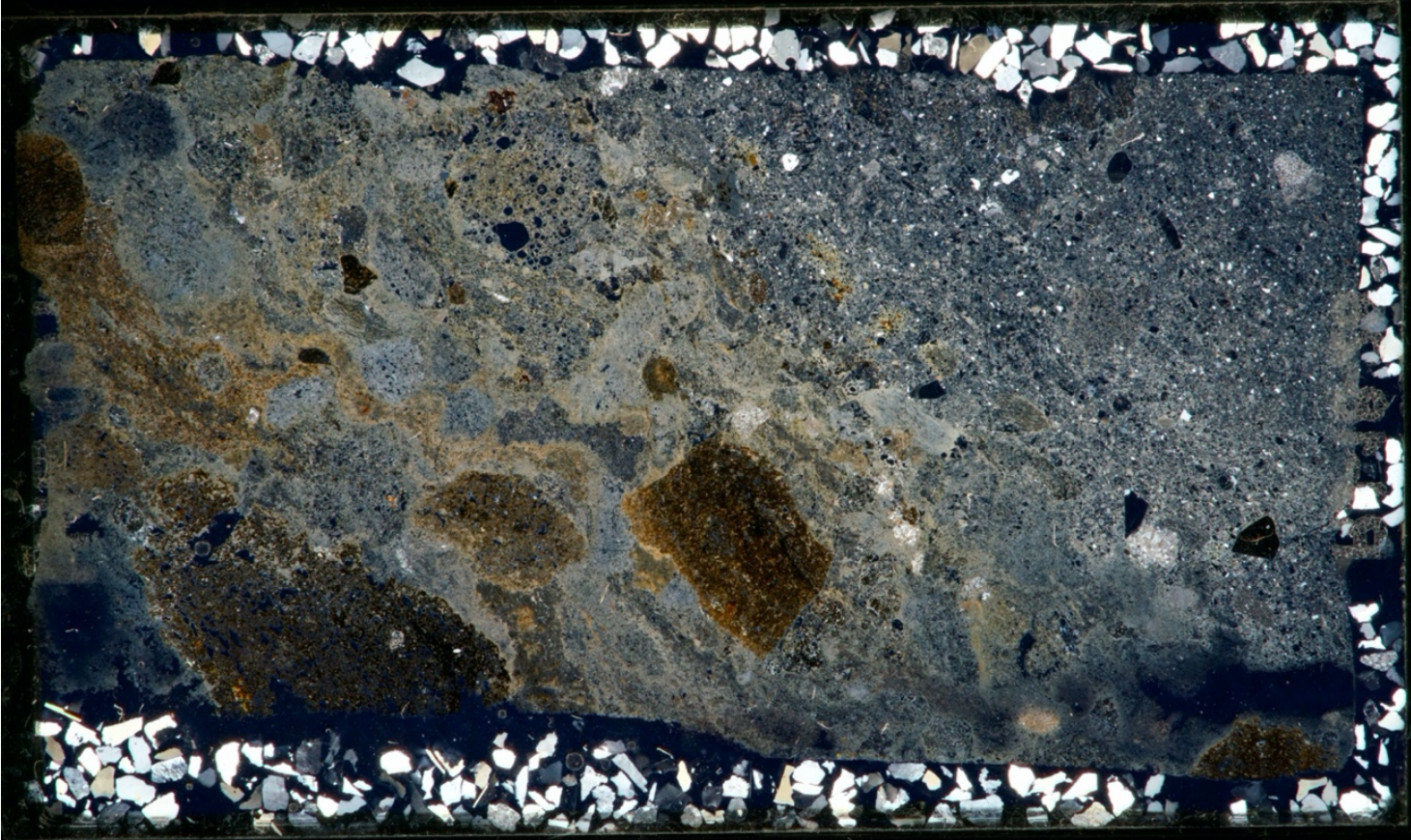

Figure 78. Thin section of Leslie Gulch ash-flow tuff, sample RJ-18-28, in cross-polarized light. 


\section{APPENDIX B: Thin Sections of Rhyolite Units}

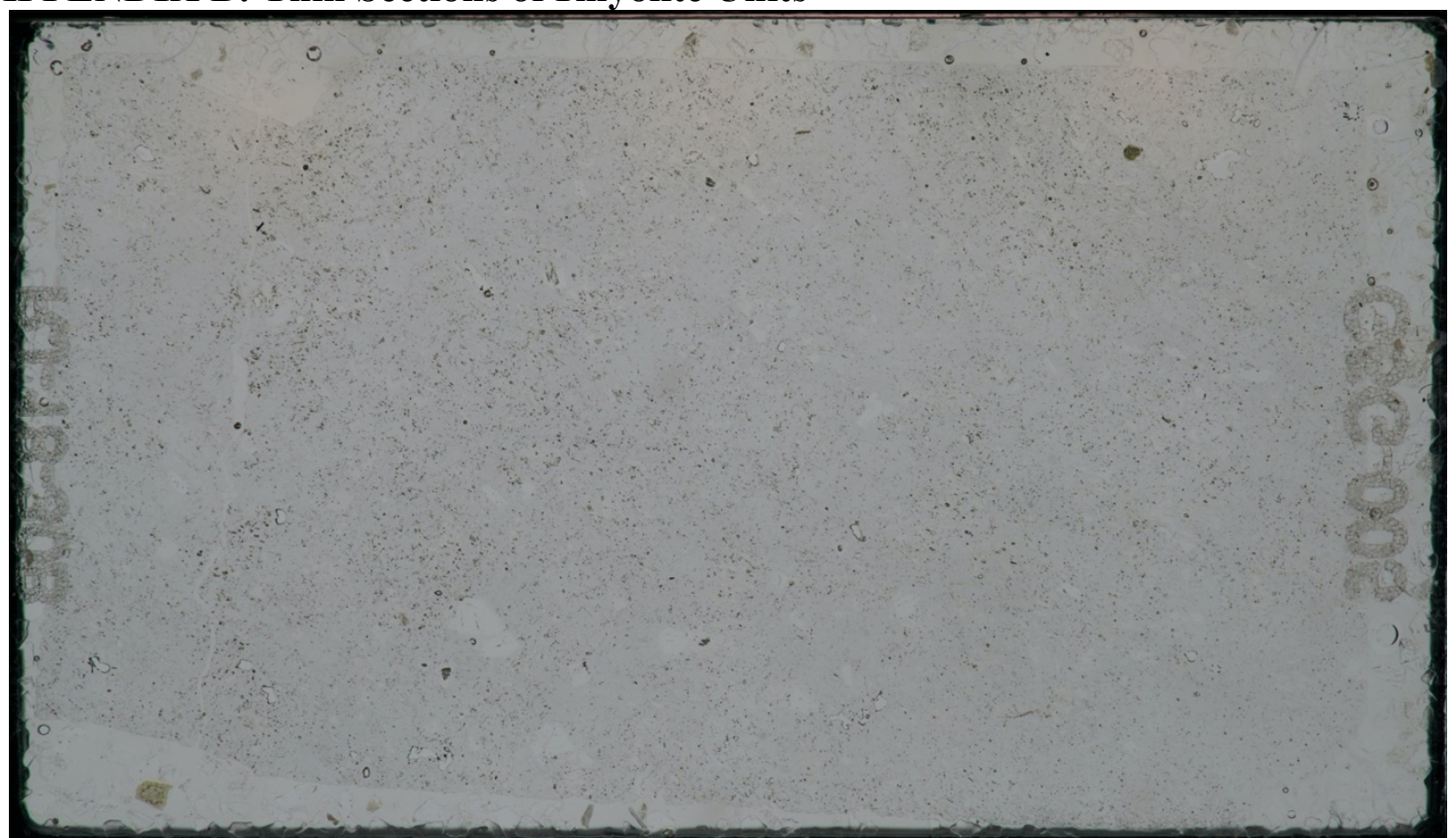

Figure 79. Thin section of glassy Mahogany Mountain rhyolite Flow unit 3, sample RJ-18-30B, in plane polarized light.

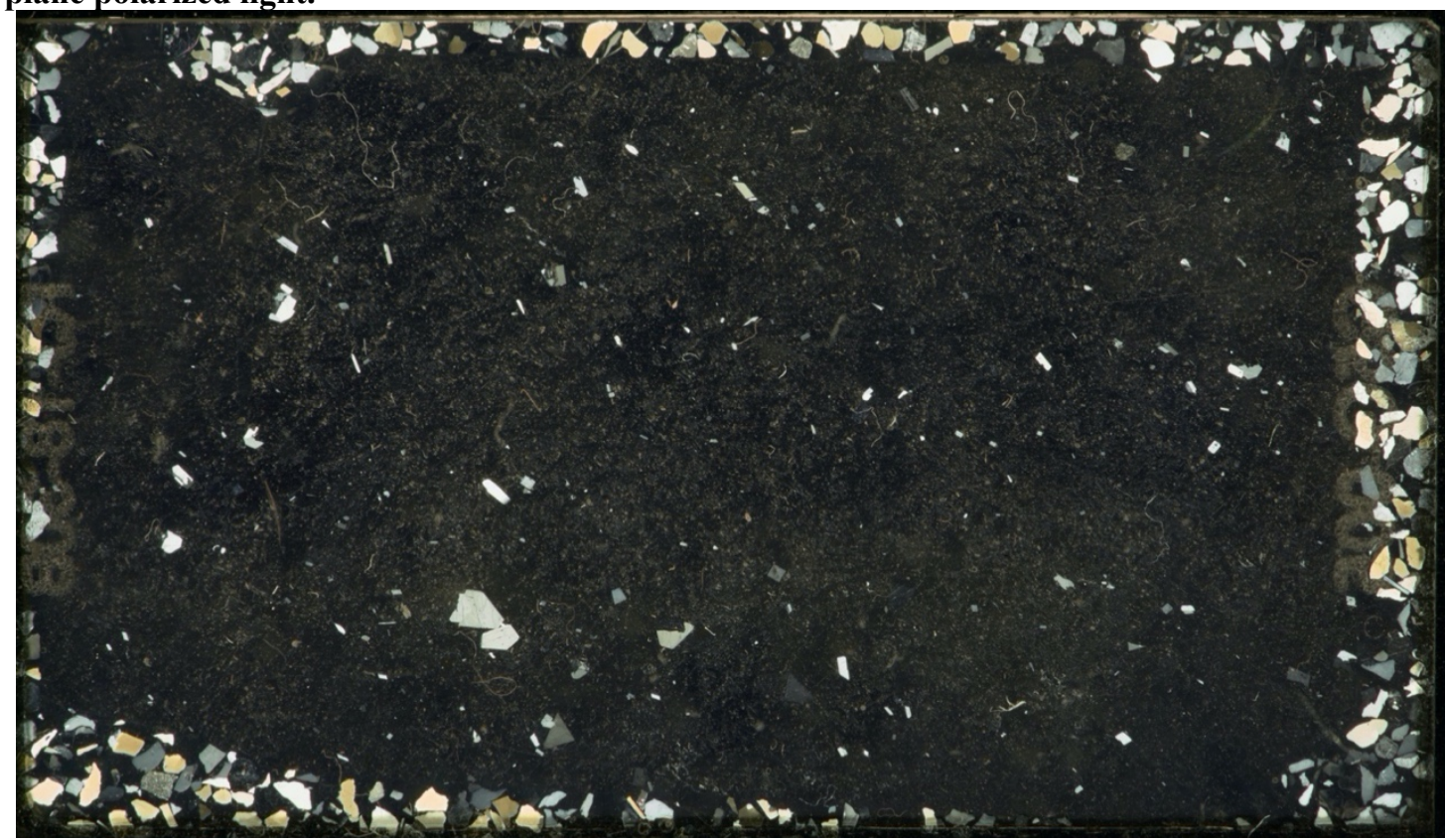

Figure 80. Thin section of glassy Mahogany Mountain rhyolite Flow unit 3, sample RJ-18-30B, in cross polarized light. 
APPENDIX B: Thin Sections of Rhyolite Units

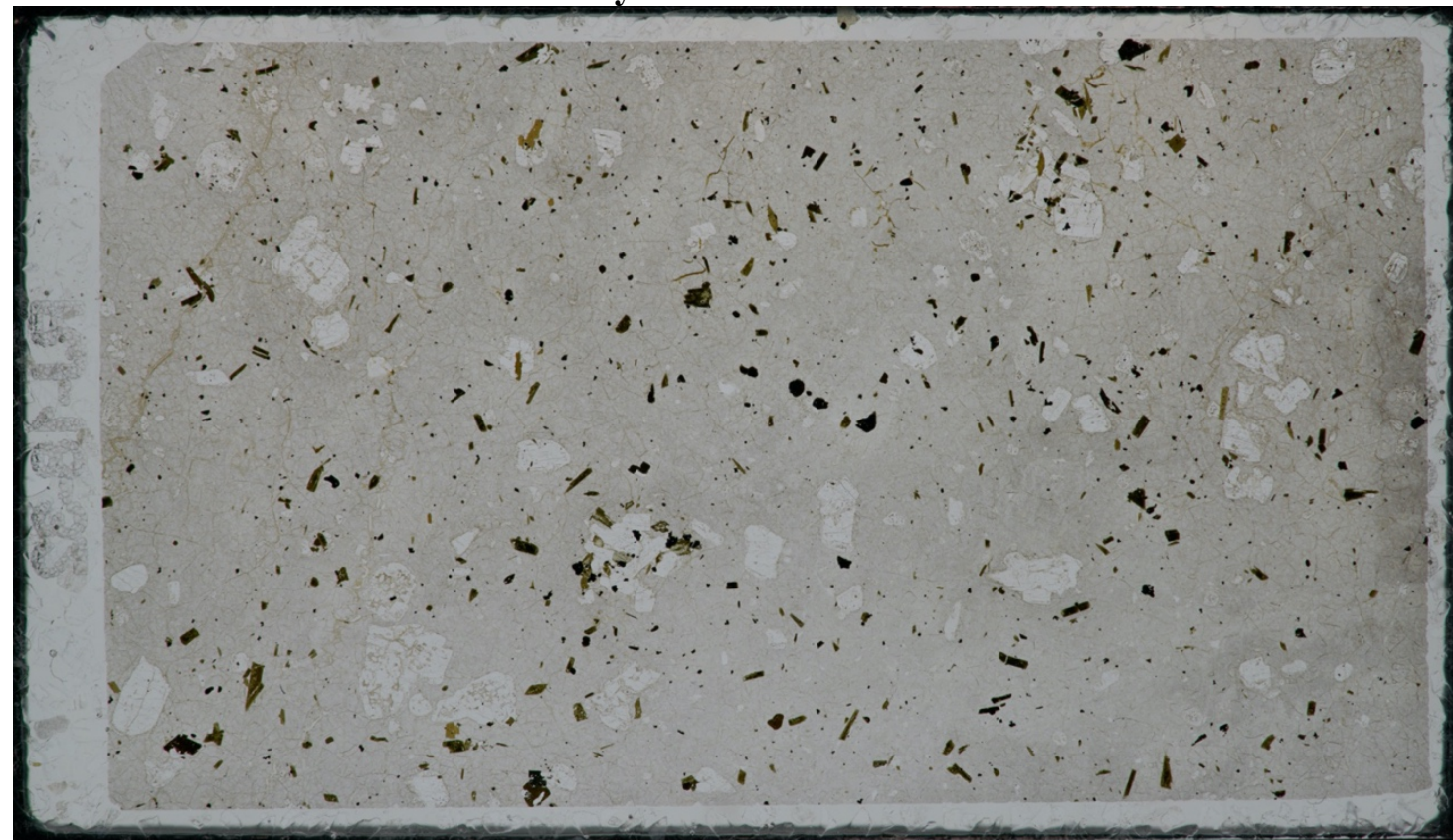

Figure 81. Thin section of glassy Birch Creek rhyolite, sample RJ-18-32, in plane polarized light.

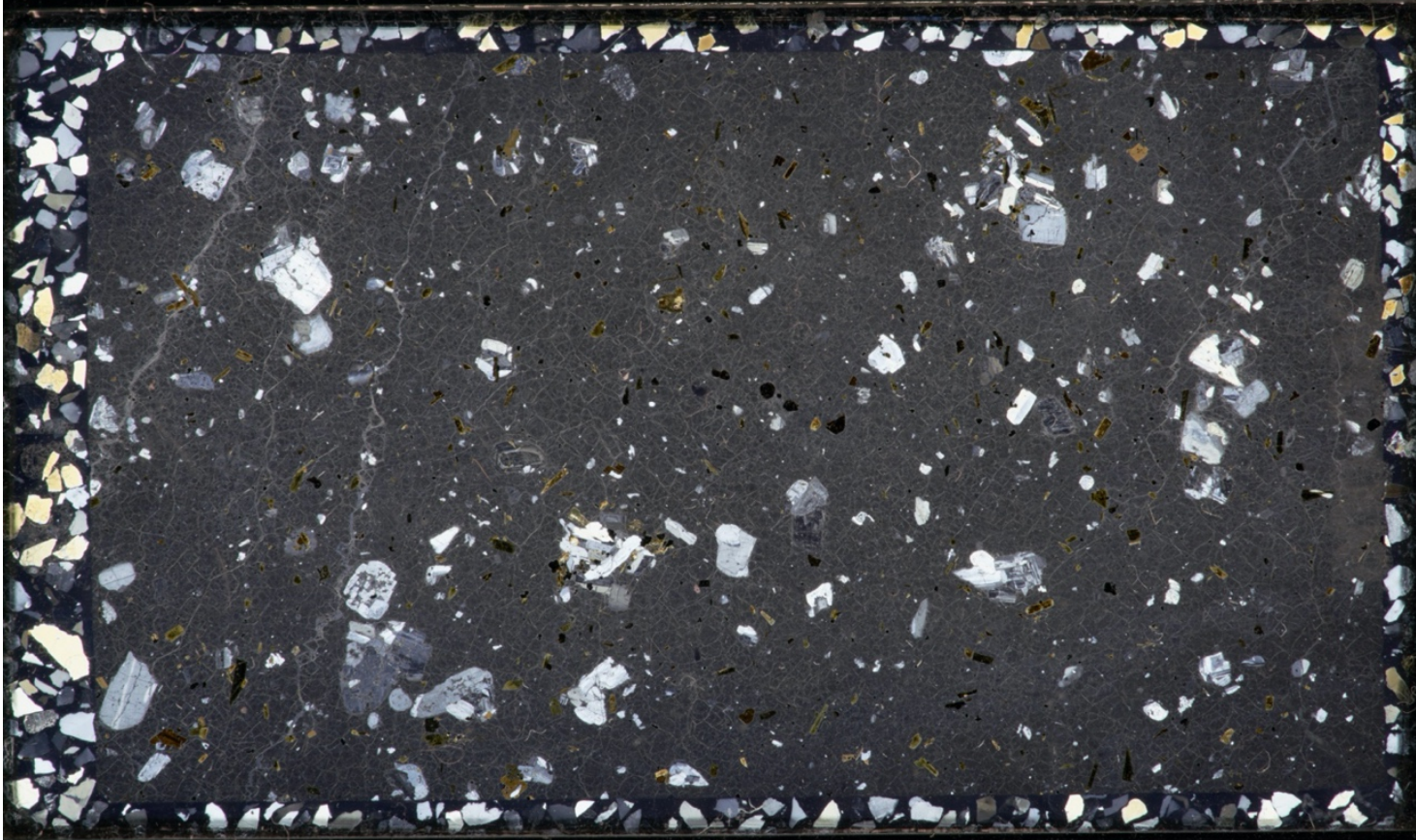

Figure 82. Thin section of glassy Birch Creek rhyolite, sample RJ-18-32, in cross polarized light. 
APPENDIX B: Thin Sections of Rhyolite Units

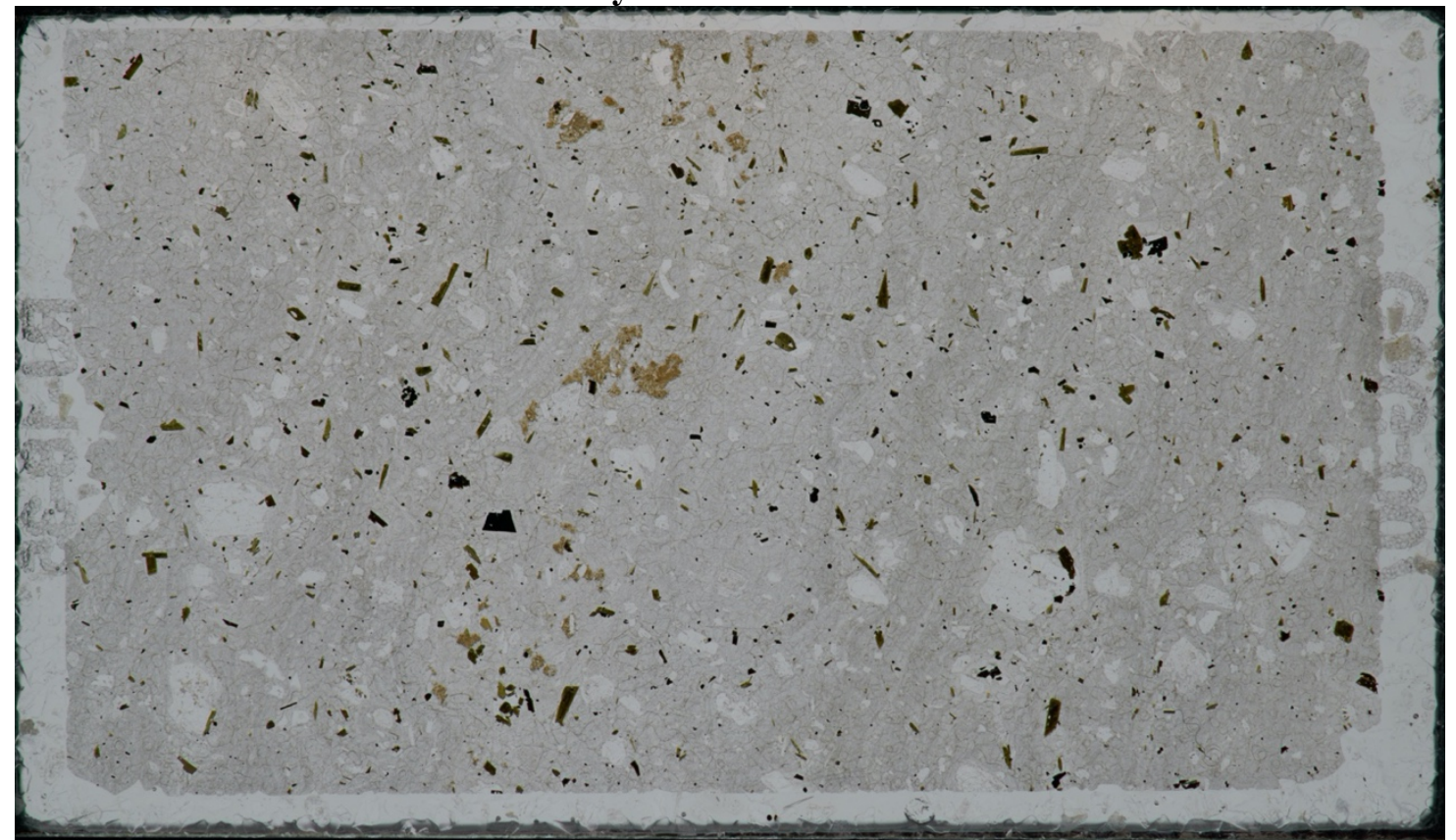

Figure 83. Thin section of glassy Birch Creek Rhyolite, sample RJ-18-35, in plane polarized light.

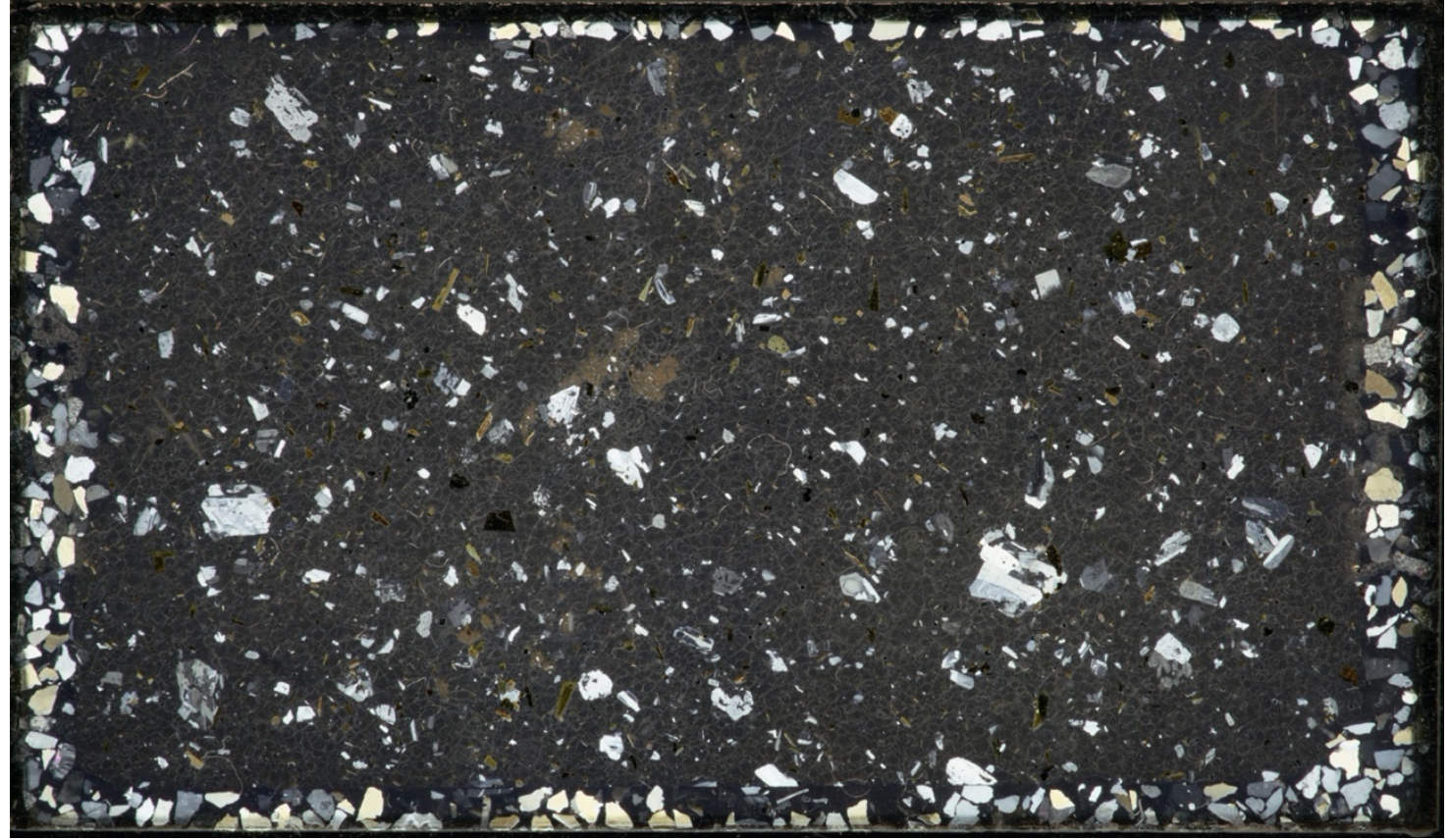

Figure 84. Thin section of glassy Birch Creek Rhyolite, sample RJ-18-35, in cross polarized light. 
APPENDIX B: Thin Sections of Rhyolite Units

Figure 85. Thin section of glassy Mahogany Mountain rhyolite Flow unit 2, sample RJ-18-50, in plane polarized light.

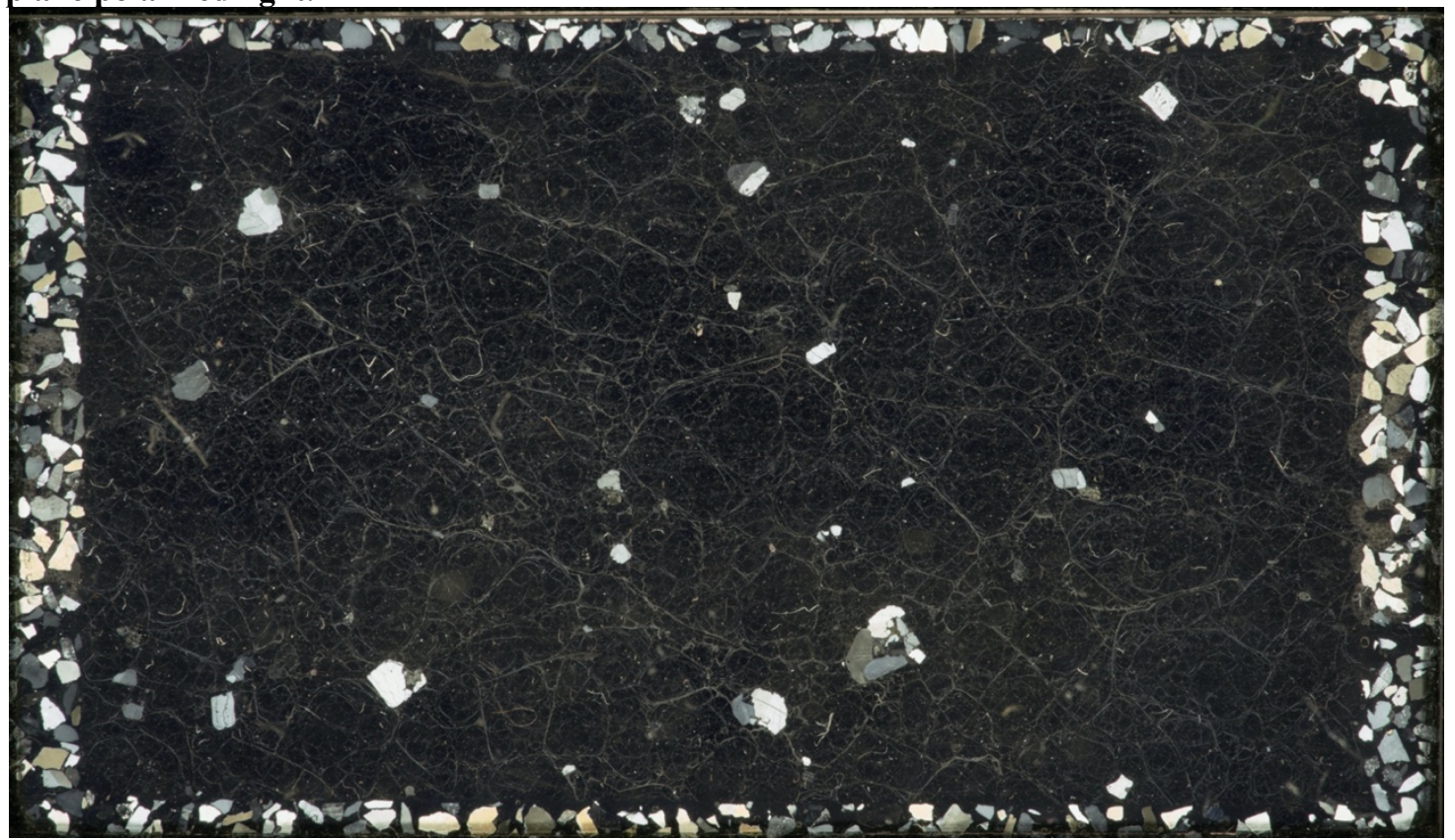

Figure 86. Thin section of glassy Mahogany Mountain rhyolite Flow unit 2, sample RJ-18-50, in cross polarized light. 
APPENDIX B: Thin Sections of Rhyolite Units

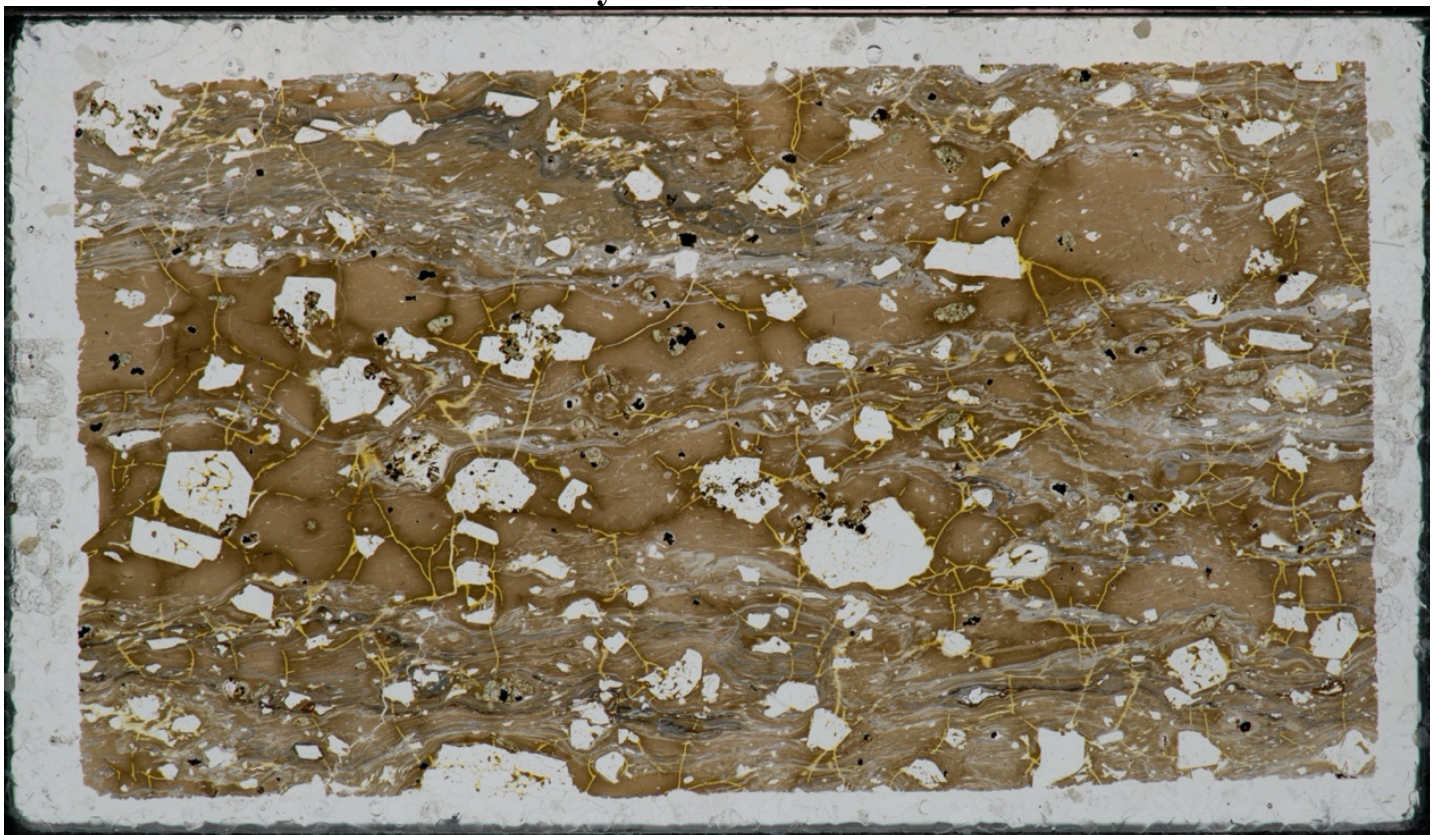

Figure 87. Thin section of glassy McCain Creek rhyolite, sample RJ-18-53, in plane polarized light.

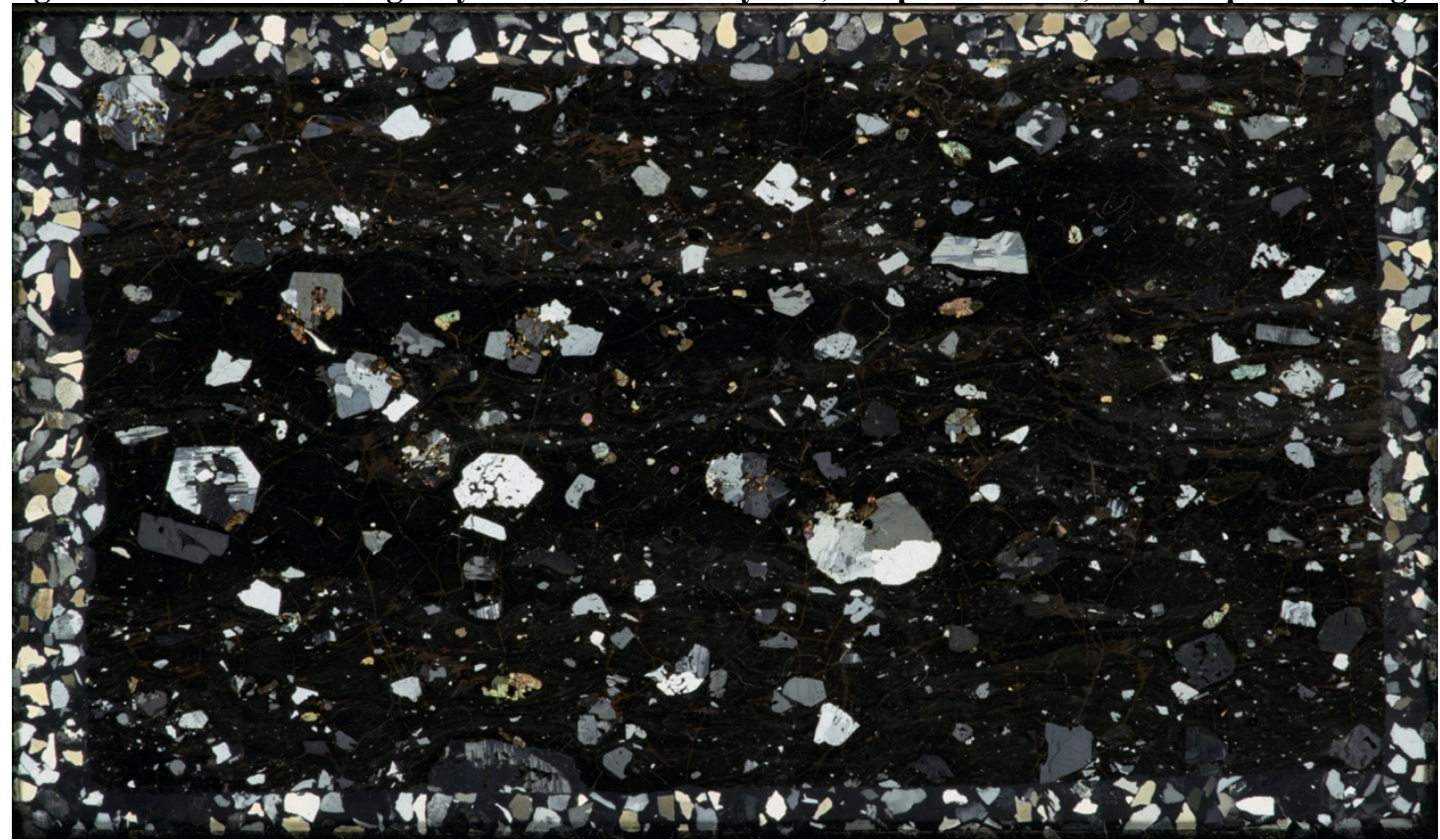

Figure 88. Thin section of glassy McCain Creek rhyolite, sample RJ-18-53, in cross polarized light. 
APPENDIX B: Thin Sections of Rhyolite Units

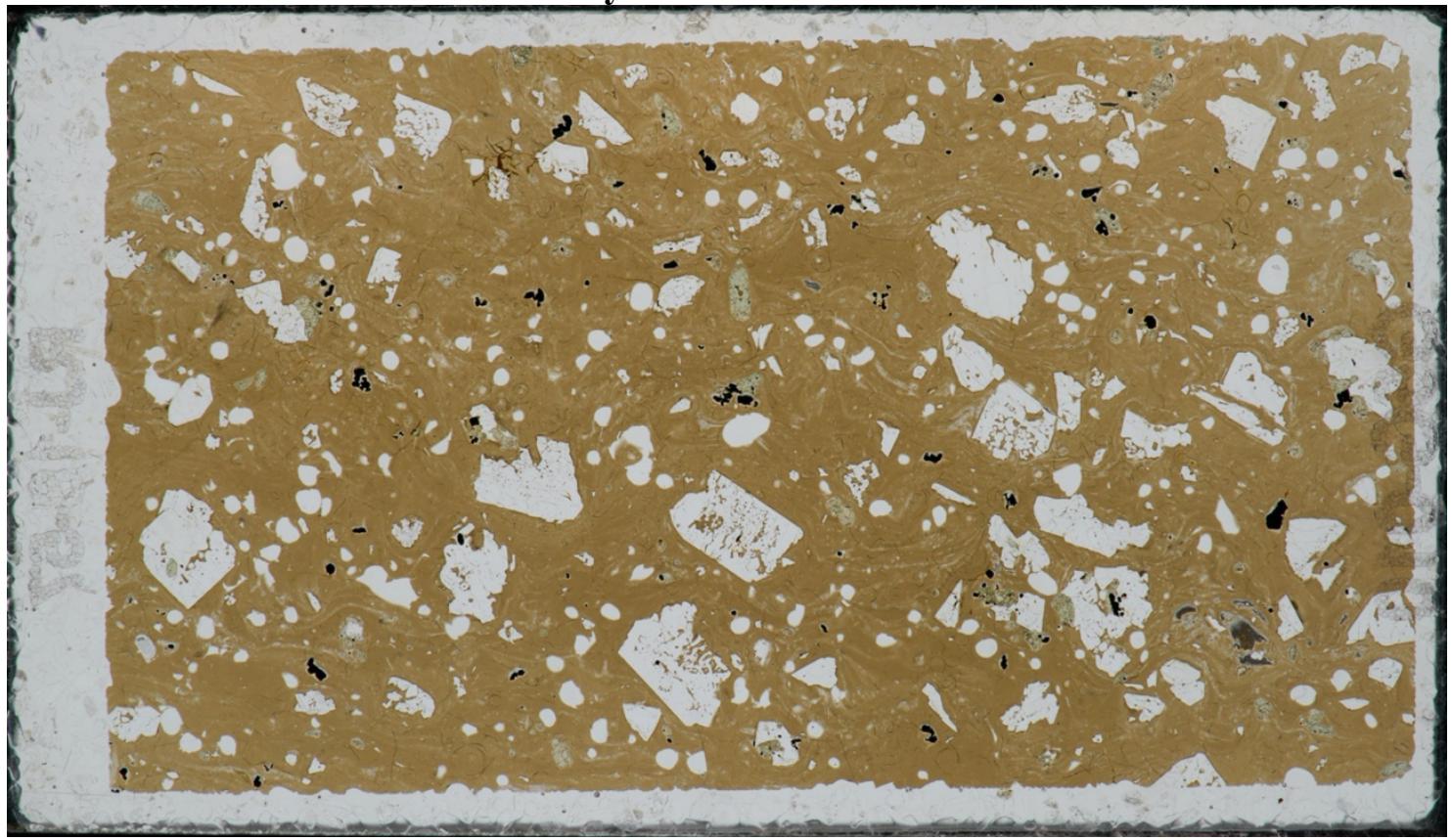

Figure 89. Thin section of glassy McCain Creek rhyolite, sample RJ-18-57, in plane polarized light.

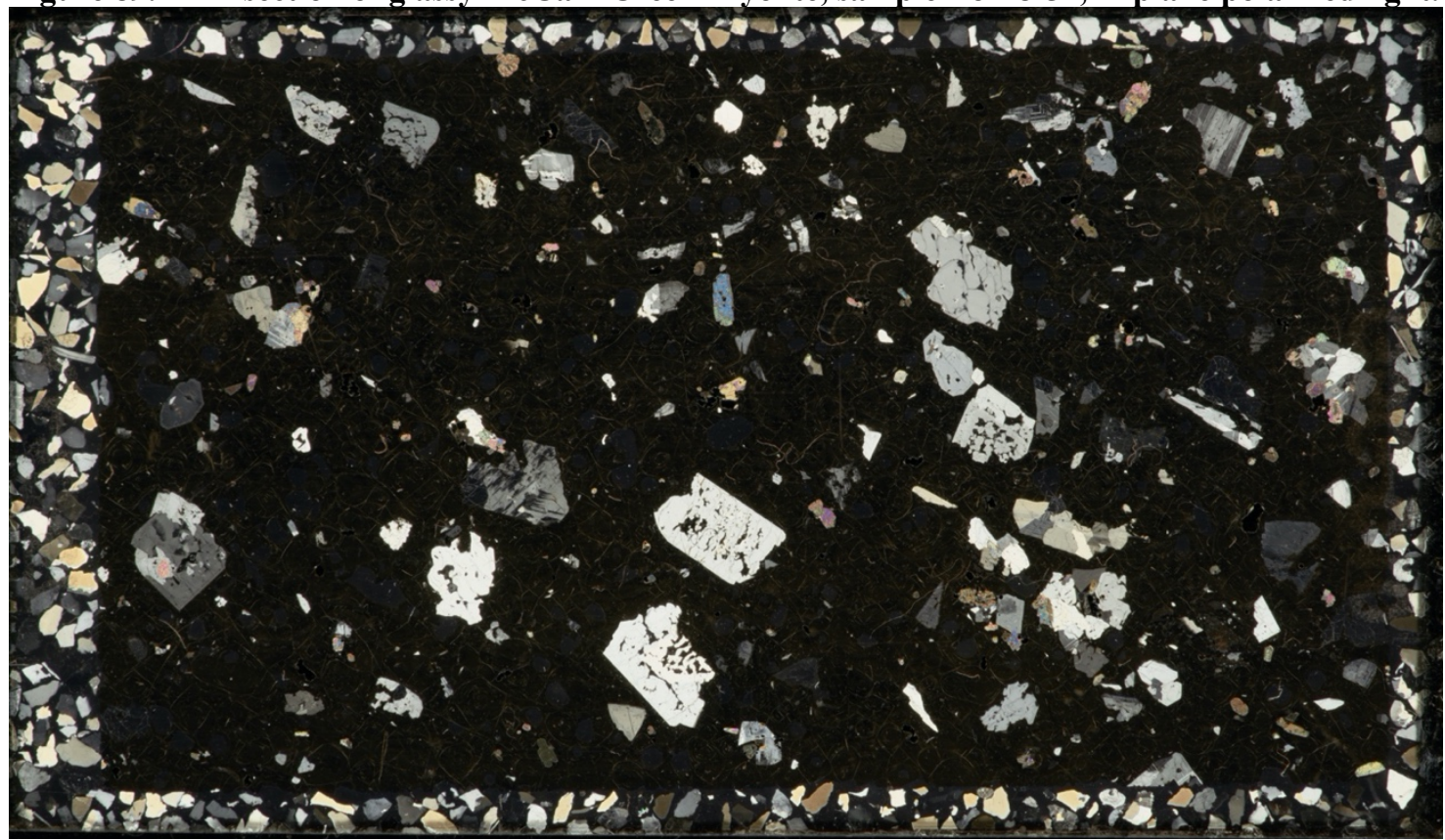

Figure 90. Thin section of glassy McCain Creek rhyolite, sample RJ-18-57, in cross polarized light. 
APPENDIX C: X-Ray Fluorescence (XRF) Chemical Data

Table 16. XRF major and trace element compositions for Bannock Ridge rhyolite and intracaldera rhyolite of the Three Fingers caldera. Sample locations are given in North American Datum 1983, universal Transverse Mercator (UTM), Zone 11N. FeO*, denotes the sum of $\mathrm{FeO} \& \mathrm{Fe}_{2} \mathrm{O}_{3}$. LOI refers to the loss of volatiles through dehydration.

\begin{tabular}{|c|c|c|c|c|}
\hline Sample & RJ-18-02 & RJ-18-04 & RJ-18-05 & RJ-18-15 \\
\hline Unit & $\begin{array}{c}\text { Bannock Ridge } \\
\text { rhyolite }\end{array}$ & $\begin{array}{l}\text { Intra-caldera } \\
\text { rhyolite }\end{array}$ & $\begin{array}{c}\text { Glassy rhyolite } \\
\text { SE of Round } \\
\text { Mtn }\end{array}$ & $\begin{array}{l}\text { Bannock Ridge } \\
\text { rhyolite }\end{array}$ \\
\hline Lat & 43.3304108 & 43.3748552 & 43.4016885 & 43.29641667 \\
\hline Long & -117.184904 & -117.129265 & -117.136126 & -117.183033 \\
\hline \multicolumn{5}{|c|}{ XRF normalized wt. $\%$} \\
\hline $\mathrm{SiO}_{2}$ & 75.86 & 76.96 & 78.70 & 75.43 \\
\hline $\mathrm{TiO}_{2}$ & 0.18 & 0.17 & 0.14 & 0.17 \\
\hline $\mathrm{Al}_{2} \mathbf{O}_{3}$ & 12.65 & 12.91 & 12.04 & 12.51 \\
\hline $\mathrm{FeO}^{*}$ & 2.18 & 1.60 & 1.43 & 2.08 \\
\hline MnO & 0.07 & 0.03 & 0.05 & 0.06 \\
\hline MgO & 0.01 & 0.40 & 0.16 & 0.01 \\
\hline $\mathrm{CaO}$ & 0.85 & 1.22 & 0.97 & 0.82 \\
\hline $\mathrm{Na}_{2} \mathbf{O}$ & 2.50 & 2.73 & 3.17 & 2.51 \\
\hline $\mathbf{K}_{2} \mathbf{O}$ & 5.68 & 3.94 & 3.31 & 6.41 \\
\hline $\mathrm{P}_{2} \mathrm{O}_{5}$ & 0.01 & 0.04 & 0.02 & 0.01 \\
\hline $\begin{array}{c}\text { Unnormalized } \\
\text { Totals }\end{array}$ & 93.17 & 96.28 & 93.46 & 95.23 \\
\hline LOI \% & 6.36 & 3.50 & 6.10 & 4.29 \\
\hline \multicolumn{5}{|l|}{$X R F, p p m$} \\
\hline $\mathbf{N i}$ & 4 & 3 & 3 & 2 \\
\hline $\mathrm{Cr}$ & 3 & 3 & 3 & 3 \\
\hline Sc & 5 & 1 & 2 & 4 \\
\hline $\mathbf{V}$ & 3 & 7 & 3 & 1 \\
\hline $\mathbf{B a}$ & 1488 & 667 & 214 & 1541 \\
\hline $\mathbf{R b}$ & 213 & 60 & 164 & 144 \\
\hline $\mathrm{Sr}$ & 79 & 179 & 39 & 84 \\
\hline $\mathbf{Z r}$ & 401 & 287 & 243 & 395 \\
\hline $\mathbf{Y}$ & 58 & 78 & 80 & 58 \\
\hline $\mathbf{N b}$ & 20 & 35 & 37 & 20 \\
\hline $\mathbf{G a}$ & 18 & 22 & 22 & 18 \\
\hline $\mathrm{Cu}$ & 4 & 9 & 6 & 4 \\
\hline $\mathbf{Z n}$ & 92 & 84 & 92 & 92 \\
\hline $\mathbf{P b}$ & 19 & 21 & 19 & 20 \\
\hline La & 43 & 62 & 52 & 43 \\
\hline $\mathrm{Ce}$ & 85 & 123 & 111 & 88 \\
\hline Th & 11 & 13 & 12 & 12 \\
\hline Nd & 41 & 52 & 45 & 43 \\
\hline $\mathbf{U}$ & 4 & 4 & 3 & 5 \\
\hline
\end{tabular}


Table 17. XRF major and trace element compositions for Mahogany Mountain rhyolite. Sample locations are given in North American Datum 1983, Universal Transverse Mercator (UTM), Zone 11N.

\begin{tabular}{|c|c|c|c|c|}
\hline Sample & RJ-18-03 & RJ-18-03A & RJ-18-06B & RJ-18-07C \\
\hline & Mahogany & Mahogany & Mahogany & Mahogany \\
\hline Unit & $\begin{array}{c}\text { Mountain } \\
\text { rhyolite }\end{array}$ & $\begin{array}{c}\text { Mountain } \\
\text { rhyolite }\end{array}$ & $\begin{array}{c}\text { Mountain } \\
\text { rhyolite }\end{array}$ & $\begin{array}{c}\text { Mountain } \\
\text { rhyolite }\end{array}$ \\
\hline Lat & 43.3304386 & 43.3304386 & 43.24005 & 43.23585 \\
\hline Long & -117.184931 & -117.184931 & -117.119333 & -117.139933 \\
\hline \multicolumn{5}{|c|}{ XRF normalized wt. $\%$} \\
\hline $\mathrm{SiO}_{2}$ & 77.97 & 78.24 & 74.68 & 75.31 \\
\hline $\mathrm{TiO}_{2}$ & 0.11 & 0.12 & 0.22 & 0.22 \\
\hline $\mathbf{A l}_{2} \mathbf{O}_{3}$ & 12.06 & 12.28 & 13.07 & 13.02 \\
\hline FeO* & 1.60 & 1.49 & 2.26 & 1.92 \\
\hline MnO & 0.06 & 0.03 & 0.07 & 0.04 \\
\hline MgO & 0.04 & 0.42 & 0.02 & 0.01 \\
\hline $\mathrm{CaO}$ & 0.31 & 0.94 & 0.90 & 0.71 \\
\hline $\mathrm{Na}_{2} \mathrm{O}$ & 3.05 & 2.26 & 4.27 & 4.20 \\
\hline $\mathbf{K}_{2} \mathbf{O}$ & 4.78 & 4.20 & 4.51 & 4.54 \\
\hline $\mathbf{P}_{2} \mathbf{O}_{5}$ & 0.01 & 0.01 & 0.02 & 0.02 \\
\hline \multicolumn{5}{|c|}{ Unnormalized } \\
\hline Totals & 93.93 & 92.12 & 99.00 & 98.72 \\
\hline LOI \% & 5.62 & 7.59 & 0.46 & 0.60 \\
\hline \multicolumn{5}{|l|}{$X R F, p p m$} \\
\hline $\mathrm{Ni}$ & 4 & 3 & 2 & 2 \\
\hline $\mathrm{Cr}$ & 3 & 3 & 3 & 3 \\
\hline Sc & 1 & 1 & 8 & 9 \\
\hline $\mathbf{V}$ & 0 & 2 & 3 & 3 \\
\hline $\mathbf{B a}$ & 200 & 225 & 1734 & 1749 \\
\hline $\mathbf{R b}$ & 237 & 220 & 120 & 119 \\
\hline $\mathbf{S r}$ & 8 & 118 & 103 & 108 \\
\hline $\mathbf{Z r}$ & 396 & 401 & 452 & 455 \\
\hline $\mathbf{Y}$ & 84 & 79 & 55 & 56 \\
\hline $\mathbf{N b}$ & 32 & 31 & 24 & 23 \\
\hline $\mathbf{G a}$ & 22 & 22 & 19 & 18 \\
\hline $\mathbf{C u}$ & 3 & 4 & 6 & 5 \\
\hline Zn & 147 & 136 & 89 & 101 \\
\hline $\mathbf{P b}$ & 23 & 19 & 19 & 20 \\
\hline La & 53 & 52 & 46 & 50 \\
\hline $\mathrm{Ce}$ & 107 & 105 & 96 & 94 \\
\hline Th & 12 & 13 & 11 & 11 \\
\hline Nd & 52 & 50 & 47 & 48 \\
\hline $\mathbf{U}$ & 6 & 5 & 5 & 5 \\
\hline
\end{tabular}


Table 18. XRF major and trace element compositions for Mahogany Mountain rhyolite. Sample locations are given in North American Datum 1983, Universal Transverse Mercator (UTM), Zone 11N.

\begin{tabular}{|c|c|c|c|c|}
\hline Sample & RJ-18-11 & RJ-18-12A & RJ-18-16B & RJ-18-17B \\
\hline & Mahogany & Mahogany & Mahogany & Mahogany \\
\hline Unit & $\begin{array}{c}\text { Mountain } \\
\text { rhyolite }\end{array}$ & $\begin{array}{l}\text { Mountain } \\
\text { rhyolite }\end{array}$ & $\begin{array}{l}\text { Mountain } \\
\text { rhyolite }\end{array}$ & $\begin{array}{c}\text { Mountain } \\
\text { rhyolite }\end{array}$ \\
\hline Lat & 43.23791667 & 43.2384 & 43.26701667 & 43.2574667 \\
\hline Long & -117.173117 & -117.165183 & -117.195733 & -117.2522 \\
\hline \multicolumn{5}{|c|}{ XRF normalized wt. $\%$} \\
\hline $\mathrm{SiO}_{2}$ & 74.43 & 74.09 & 77.08 & 75.62 \\
\hline $\mathrm{TiO}_{2}$ & 0.22 & 0.22 & 0.11 & 0.17 \\
\hline $\mathbf{A l}_{2} \mathbf{O}_{3}$ & 13.05 & 13.12 & 12.17 & 12.72 \\
\hline FeO* & 2.49 & 2.58 & 1.41 & 2.00 \\
\hline MnO & 0.07 & 0.08 & 0.02 & 0.06 \\
\hline MgO & 0.03 & 0.16 & 0.06 & 0.03 \\
\hline $\mathrm{CaO}$ & 0.95 & 1.05 & 0.23 & 0.74 \\
\hline $\mathrm{Na}_{2} \mathrm{O}$ & 3.25 & 3.02 & 2.82 & 2.50 \\
\hline $\mathbf{K}_{2} \mathbf{O}$ & 5.49 & 5.67 & 6.10 & 6.15 \\
\hline $\mathbf{P}_{2} \mathbf{O}_{5}$ & 0.02 & 0.01 & 0.01 & 0.01 \\
\hline \multicolumn{5}{|c|}{ Unnormalized } \\
\hline Totals & 96.20 & 95.08 & 95.49 & 93.75 \\
\hline LOI \% & 3.27 & 4.36 & 3.99 & 5.77 \\
\hline \multicolumn{5}{|l|}{$X R F, p p m$} \\
\hline $\mathrm{Ni}$ & 1 & 1 & 3 & 0 \\
\hline $\mathrm{Cr}$ & 3 & 2 & 2 & 3 \\
\hline Sc & 8 & 8 & 2 & 4 \\
\hline $\mathbf{V}$ & 4 & 2 & 2 & 1 \\
\hline $\mathbf{B a}$ & 1668 & 1623 & 316 & 1552 \\
\hline $\mathbf{R b}$ & 119 & 115 & 152 & 149 \\
\hline $\mathbf{S r}$ & 105 & 101 & 8 & 70 \\
\hline $\mathbf{Z r}$ & 446 & 439 & 367 & 410 \\
\hline $\mathbf{Y}$ & 54 & 54 & 78 & 55 \\
\hline $\mathbf{N b}$ & 22 & 23 & 29 & 23 \\
\hline $\mathbf{G a}$ & 18 & 18 & 22 & 17 \\
\hline $\mathbf{C u}$ & 5 & 4 & 5 & 3 \\
\hline $\mathbf{Z n}$ & 92 & 92 & 128 & 91 \\
\hline $\mathbf{P b}$ & 20 & 19 & 21 & 19 \\
\hline $\mathbf{L a}$ & 45 & 46 & 56 & 46 \\
\hline $\mathrm{Ce}$ & 92 & 91 & 114 & 87 \\
\hline Th & 11 & 11 & 13 & 11 \\
\hline Nd & 44 & 43 & 55 & 43 \\
\hline $\mathbf{U}$ & 5 & 5 & 6 & 5 \\
\hline
\end{tabular}


Table 19. XRF major and trace element compositions for Mahogany Mountain rhyolite. Sample locations are given in North American Datum 1983, universal Transverse Mercator (UTM), Zone 11N.

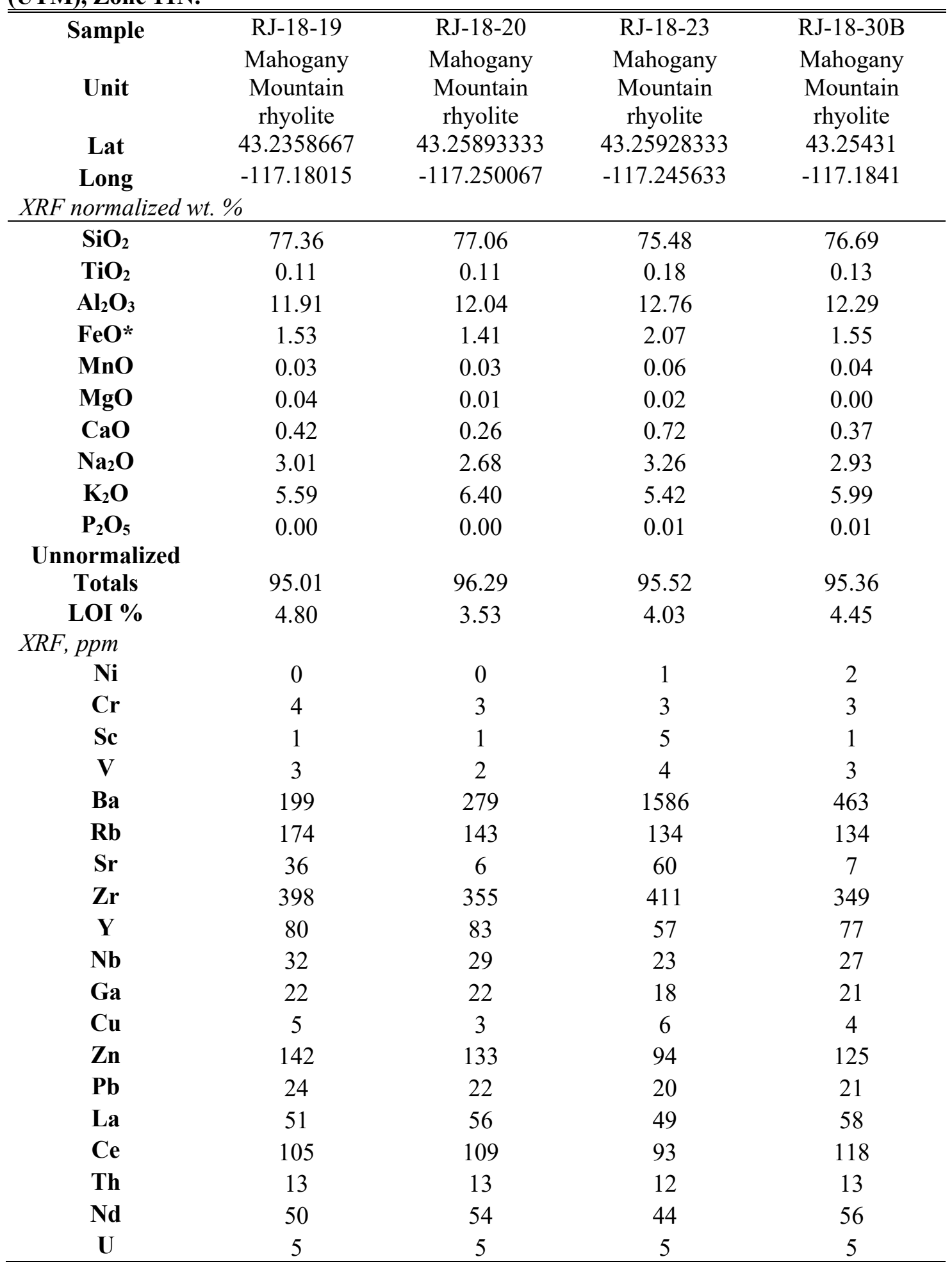


Table 20. XRF major and trace element compositions for Mahogany Mountain rhyolite. Sample locations are given in North American Datum 1983, universal Transverse Mercator (UTM), Zone 11N.

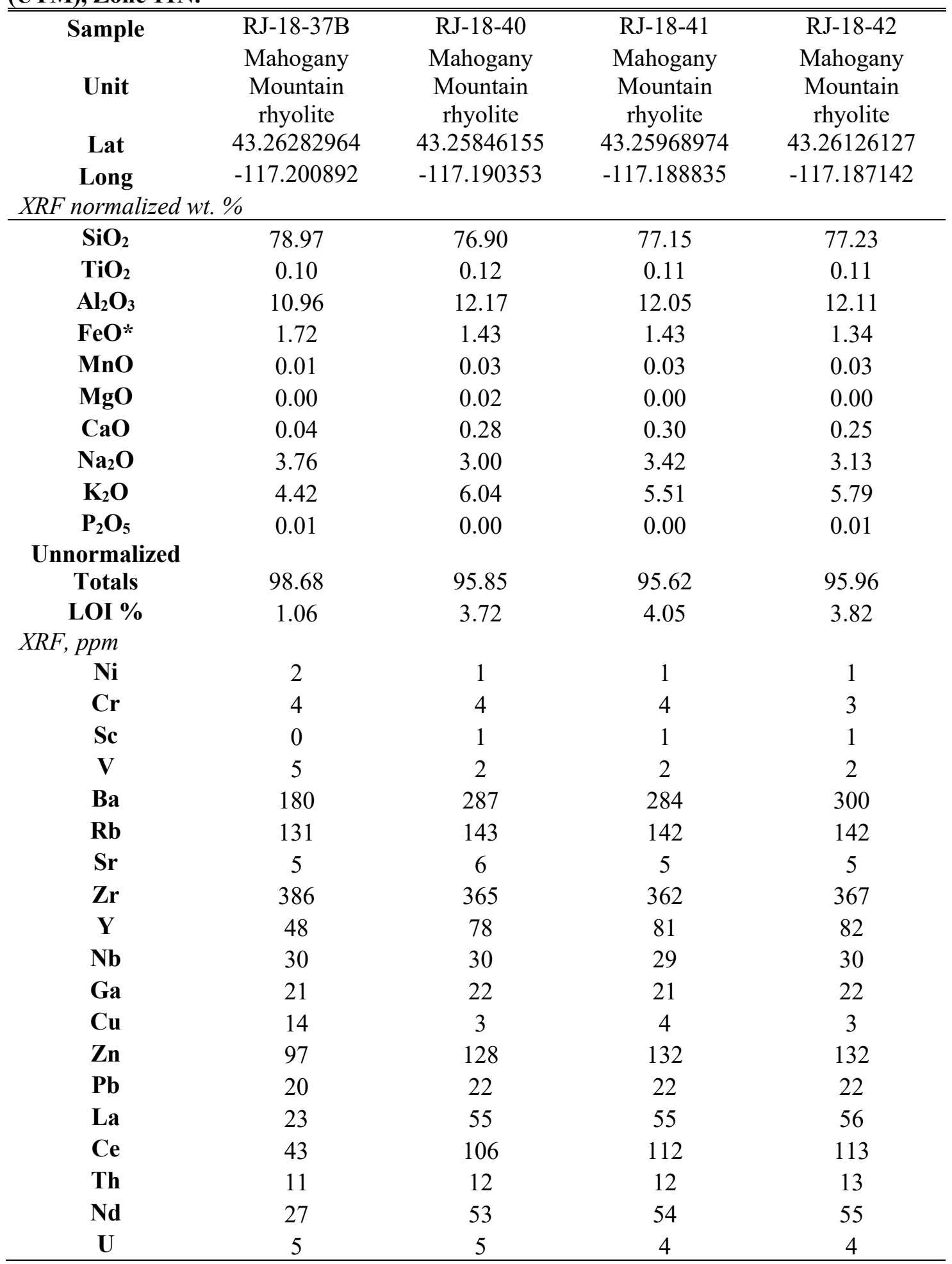


Table 21. XRF major and trace element compositions for Mahogany Mountain rhyolite. Sample locations are given in North American Datum 1983, universal Transverse Mercator (UTM), Zone 11N.

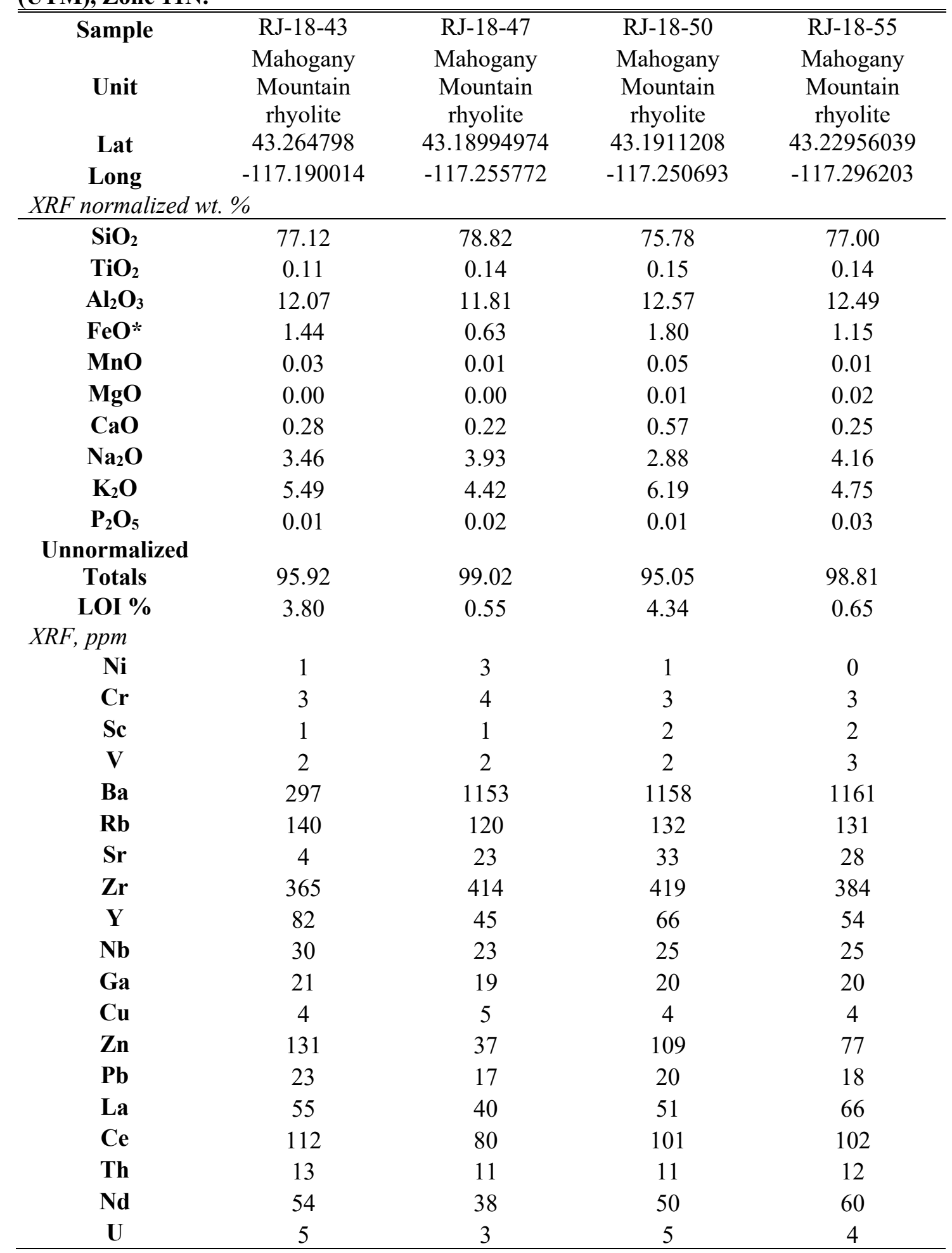


Table 22. XRF major and trace element compositions for Mahogany Mountain rhyolite, Tuff of Leslie Gulch, and Birch Creek rhyolite. Sample locations are given in North American Datum 1983, universal Transverse Mercator (UTM), Zone 11N.

\begin{tabular}{|c|c|c|c|c|}
\hline Sample & RJ-18-56 & RJ-18-28 & RJ-18-32 & RJ-18-35 \\
\hline Unit & $\begin{array}{l}\text { Mahogany } \\
\text { Mountain } \\
\text { rhyolite }\end{array}$ & $\begin{array}{c}\text { Tuff of Leslie } \\
\text { Gulch (Ash } \\
\text { Flow Tuff) }\end{array}$ & $\begin{array}{l}\text { Birch Creek } \\
\text { rhyolite }\end{array}$ & $\begin{array}{l}\text { Birch Creek } \\
\text { rhyolite }\end{array}$ \\
\hline Lat & 43.23252538 & 43.23881667 & 43.2249 & 43.2062333 \\
\hline Long & -117.2973 & -117.174633 & -117.49102 & -117.4947 \\
\hline \multicolumn{5}{|c|}{ XRF normalized wt. \% } \\
\hline $\mathrm{SiO}_{2}$ & 76.43 & 63.47 & 72.81 & 72.95 \\
\hline $\mathrm{TiO}_{2}$ & 0.14 & 1.58 & 0.28 & 0.28 \\
\hline $\mathbf{A l}_{2} \mathbf{O}_{3}$ & 12.59 & 13.77 & 14.49 & 14.34 \\
\hline $\mathrm{FeO}^{*}$ & 1.56 & 9.95 & 2.24 & 2.22 \\
\hline MnO & 0.03 & 0.11 & 0.06 & 0.06 \\
\hline MgO & 0.00 & 1.62 & 0.56 & 0.54 \\
\hline $\mathrm{CaO}$ & 0.22 & 4.64 & 2.03 & 1.80 \\
\hline $\mathrm{Na}_{2} \mathrm{O}$ & 4.12 & 1.32 & 4.83 & 4.65 \\
\hline $\mathbf{K}_{2} \mathbf{O}$ & 4.89 & 2.24 & 2.61 & 3.07 \\
\hline $\mathbf{P}_{2} \mathbf{O}_{5}$ & 0.02 & 1.30 & 0.09 & 0.09 \\
\hline \multicolumn{5}{|c|}{ Unnormalized } \\
\hline Totals & 99.18 & 86.19 & 92.83 & 94.87 \\
\hline LOI \% & 0.43 & 13.28 & 6.74 & 4.72 \\
\hline \multicolumn{5}{|l|}{$X R F, p p m$} \\
\hline $\mathbf{N i}$ & 2 & 4 & 3 & 2 \\
\hline $\mathrm{Cr}$ & 3 & 2 & 4 & 4 \\
\hline Sc & 2 & 20 & 5 & 5 \\
\hline $\mathbf{V}$ & 7 & 130 & 25 & 23 \\
\hline $\mathbf{B a}$ & 1083 & 1051 & 1083 & 1225 \\
\hline $\mathbf{R b}$ & 135 & 70 & 143 & 145 \\
\hline $\mathrm{Sr}$ & 20 & 305 & 223 & 220 \\
\hline $\mathbf{Z r}$ & 384 & 336 & 195 & 199 \\
\hline $\mathbf{Y}$ & 54 & 123 & 25 & 25 \\
\hline $\mathbf{N b}$ & 26 & 19 & 11 & 11 \\
\hline $\mathbf{G a}$ & 20 & 17 & 16 & 16 \\
\hline $\mathbf{C u}$ & 5 & 11 & 13 & 11 \\
\hline $\mathbf{Z n}$ & 91 & 135 & 44 & 47 \\
\hline $\mathbf{P b}$ & 16 & 12 & 15 & 15 \\
\hline La & 56 & 70 & 28 & 29 \\
\hline $\mathrm{Ce}$ & 105 & 114 & 51 & 51 \\
\hline Th & 12 & 6 & 7 & 7 \\
\hline Nd & 53 & 68 & 22 & 22 \\
\hline $\mathbf{U}$ & 4 & 12 & 4 & 3 \\
\hline
\end{tabular}


Table 23. XRF major and trace element compositions for samples of the McCain Creek rhyolite. Sample locations are given in North American Datum 1983, universal Transverse Mercator (UTM), Zone 11N.

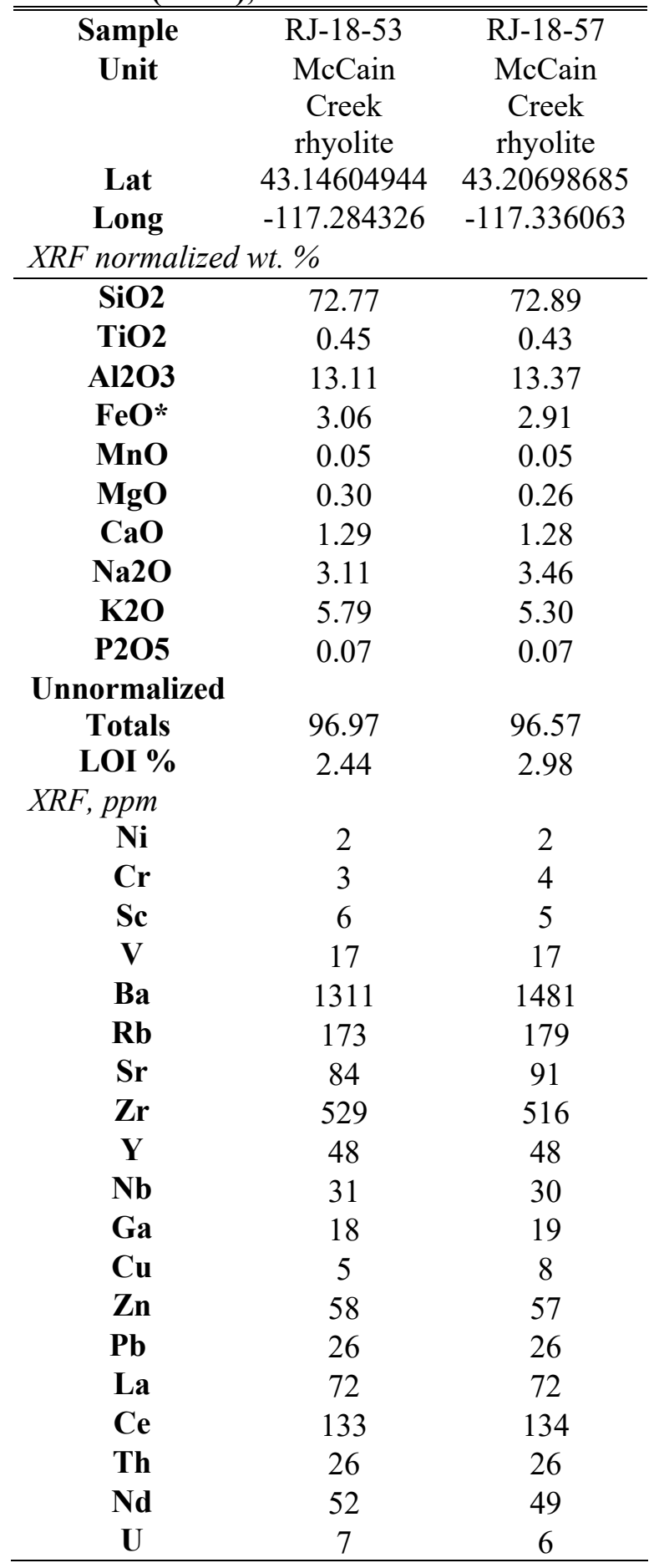




\section{APPENDIX D: Inductively Coupled Plasma-Mass Spectrometry (ICP-MS) Chemical Data}

Table 24. ICP-MS trace element compositions for samples of the Bannock Ridge rhyolite, glassy rhyolite SE of Round Mountain and intra-caldera rhyolite.

\begin{tabular}{|c|c|c|c|c|}
\hline Sample & RJ-18-02 & RJ-18-04 & RJ-18-05 & RJ-18-15 \\
\hline Unit & $\begin{array}{c}\text { Bannock } \\
\text { Ridge } \\
\text { rhyolite }\end{array}$ & $\begin{array}{l}\text { Intra-caldera } \\
\text { rhyolite }\end{array}$ & $\begin{array}{c}\text { Glassy } \\
\text { rhyolite SE } \\
\text { of Round } \\
\text { Mtn }\end{array}$ & $\begin{array}{c}\text { Bannock } \\
\text { Ridge } \\
\text { rhyolite }\end{array}$ \\
\hline \multicolumn{5}{|c|}{$I C P-M S$, ppm } \\
\hline La & 43.47 & 61.78 & 53.93 & 44.42 \\
\hline $\mathrm{Ce}$ & 89.44 & 124.12 & 111.05 & 91.64 \\
\hline Pr & 11.22 & 15.02 & 12.84 & 11.29 \\
\hline Nd & 43.62 & 55.00 & 47.60 & 44.01 \\
\hline Sm & 9.82 & 12.07 & 10.93 & 9.92 \\
\hline $\mathbf{E u}$ & 1.71 & 0.64 & 0.43 & 1.76 \\
\hline Gd & 9.25 & 11.54 & 10.60 & 9.63 \\
\hline $\mathbf{T b}$ & 1.63 & 2.14 & 2.03 & 1.68 \\
\hline Dy & 10.35 & 13.97 & 13.80 & 10.38 \\
\hline Ho & 2.18 & 2.95 & 2.91 & 2.27 \\
\hline $\mathbf{E r}$ & 6.11 & 8.66 & 8.62 & 6.38 \\
\hline $\mathbf{T m}$ & 0.95 & 1.33 & 1.38 & 0.95 \\
\hline $\mathbf{Y b}$ & 6.00 & 8.67 & 8.83 & 6.09 \\
\hline Lu & 0.93 & 1.33 & 1.32 & 0.96 \\
\hline Ba & 1515.15 & 682.11 & 220.23 & 1581.72 \\
\hline Th & 11.84 & 13.44 & 12.86 & 12.15 \\
\hline $\mathbf{N b}$ & 20.22 & 34.99 & 35.00 & 20.66 \\
\hline $\mathbf{Y}$ & 56.78 & 76.28 & 76.96 & 58.32 \\
\hline Hf & 10.29 & 8.21 & 8.02 & 10.38 \\
\hline $\mathbf{T a}$ & 1.35 & 2.33 & 2.31 & 1.38 \\
\hline $\mathbf{U}$ & 5.16 & 3.72 & 4.07 & 5.38 \\
\hline $\mathbf{P b}$ & 19.03 & 19.94 & 19.17 & 19.77 \\
\hline $\mathbf{R b}$ & 210.9 & 59.2 & 162.1 & 142.68 \\
\hline Cs & 5.64 & 1.80 & 7.11 & 5.01 \\
\hline $\mathrm{Sr}$ & 77.34 & 176.72 & 38.46 & 83.74 \\
\hline Sc & 3.53 & 2.03 & 1.55 & 3.27 \\
\hline $\mathbf{Z r}$ & 393.15 & 239.04 & 216.06 & 397.50 \\
\hline
\end{tabular}


Table 25. ICP-MS trace element compositions for samples of the Mahogany Mountain rhyolite.

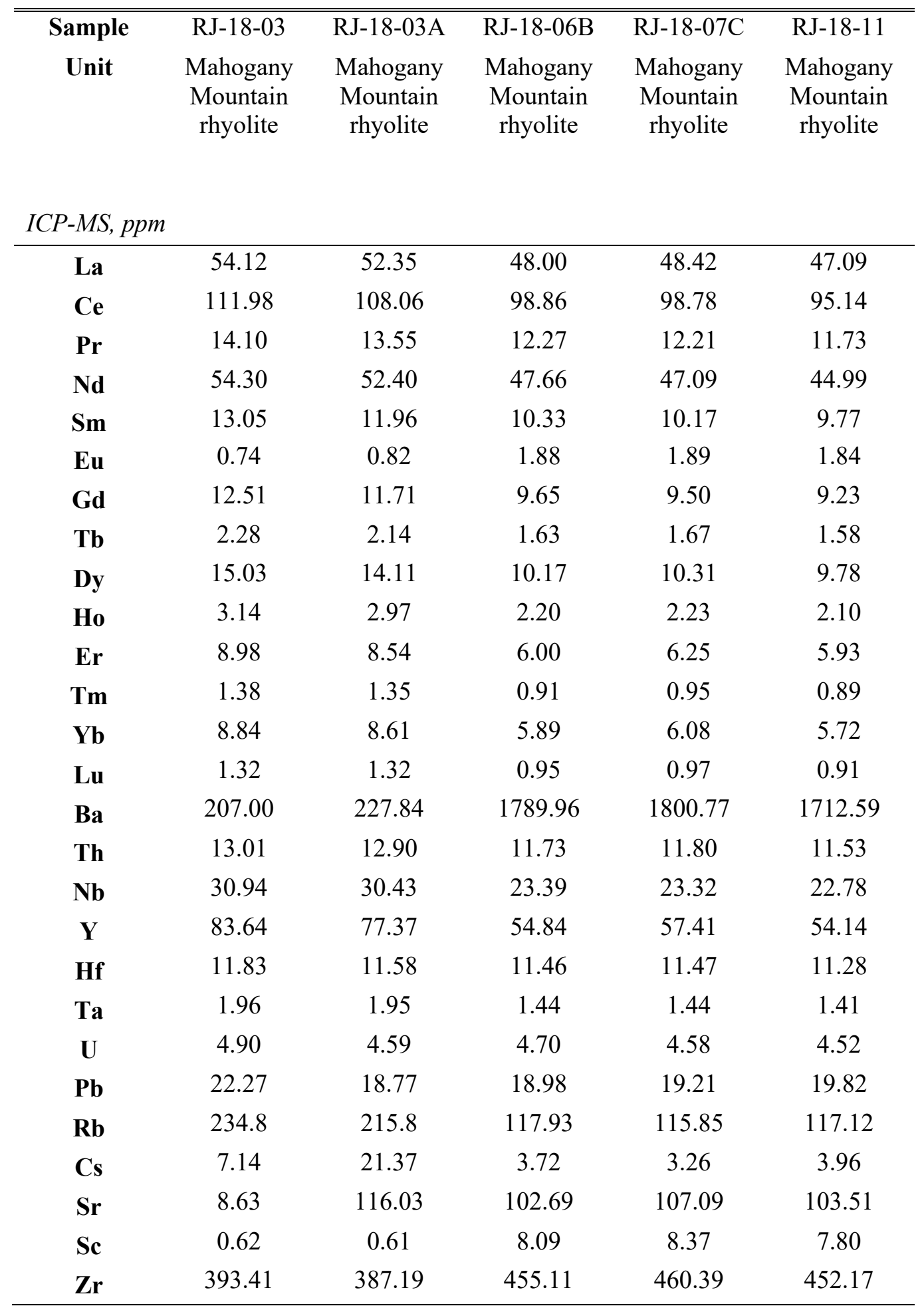


Table 26. ICP-MS trace element compositions for samples of the Mahogany Mountain rhyolite.

\begin{tabular}{|c|c|c|c|c|c|}
\hline Sample & RJ-18-12A & RJ-18-16B & RJ-18-17B & RJ-18-19 & RJ-18-20 \\
\hline Unit & $\begin{array}{l}\text { Mahogany } \\
\text { Mountain } \\
\text { rhyolite }\end{array}$ & $\begin{array}{c}\text { Mahogany } \\
\text { Mountain } \\
\text { rhyolite }\end{array}$ & $\begin{array}{l}\text { Mahogany } \\
\text { Mountain } \\
\text { rhyolite }\end{array}$ & $\begin{array}{l}\text { Mahogany } \\
\text { Mountain } \\
\text { rhyolite }\end{array}$ & $\begin{array}{c}\text { Mahogany } \\
\text { Mountain } \\
\text { rhyolite }\end{array}$ \\
\hline \multicolumn{6}{|c|}{$I C P-M S, p p m$} \\
\hline La & 46.96 & 58.34 & 47.35 & 51.85 & 56.80 \\
\hline $\mathrm{Ce}$ & 94.91 & 116.11 & 95.09 & 109.63 & 115.07 \\
\hline $\operatorname{Pr}$ & 11.65 & 14.68 & 11.74 & 13.51 & 14.62 \\
\hline Nd & 45.09 & 56.91 & 44.83 & 52.60 & 56.10 \\
\hline Sm & 9.77 & 12.94 & 9.81 & 12.11 & 12.58 \\
\hline $\mathbf{E u}$ & 1.82 & 0.78 & 1.55 & 0.72 & 0.83 \\
\hline Gd & 9.19 & 12.44 & 9.24 & 12.20 & 12.65 \\
\hline $\mathbf{T b}$ & 1.56 & 2.22 & 1.62 & 2.24 & 2.28 \\
\hline Dy & 9.67 & 13.93 & 9.97 & 14.33 & 14.46 \\
\hline Но & 2.06 & 3.03 & 2.15 & 3.13 & 3.17 \\
\hline $\mathbf{E r}$ & 5.82 & 8.39 & 5.96 & 8.63 & 8.74 \\
\hline $\mathbf{T m}$ & 0.86 & 1.26 & 0.89 & 1.32 & 1.35 \\
\hline $\mathbf{Y b}$ & 5.68 & 8.08 & 5.92 & 8.43 & 8.32 \\
\hline $\mathbf{L u}$ & 0.90 & 1.24 & 0.94 & 1.26 & 1.30 \\
\hline $\mathbf{B a}$ & 1649.30 & 318.84 & 1589.41 & 200.20 & 283.27 \\
\hline Th & 11.37 & 13.10 & 12.01 & 13.21 & 13.02 \\
\hline $\mathbf{N b}$ & 22.59 & 29.49 & 22.32 & 30.72 & 29.17 \\
\hline $\mathbf{Y}$ & 53.04 & 77.89 & 55.73 & 79.05 & 82.01 \\
\hline Hf & 11.02 & 11.21 & 10.54 & 12.09 & 10.91 \\
\hline Ta & 1.37 & 1.90 & 1.42 & 1.98 & 1.89 \\
\hline $\mathbf{U}$ & 4.46 & 4.84 & 4.77 & 4.94 & 4.89 \\
\hline $\mathbf{P b}$ & 18.39 & 21.63 & 18.81 & 22.78 & 21.80 \\
\hline $\mathbf{R b}$ & 112.68 & 149.70 & 146.22 & 169.92 & 141.38 \\
\hline Cs & 3.64 & 4.12 & 4.48 & 9.74 & 4.28 \\
\hline $\mathrm{Sr}$ & 98.95 & 8.85 & 69.32 & 35.86 & 5.33 \\
\hline Sc & 7.87 & 0.58 & 4.26 & 0.38 & 0.61 \\
\hline $\mathbf{Z r}$ & 440.14 & 367.38 & 409.16 & 396.42 & 353.51 \\
\hline
\end{tabular}


Table 27. ICP-MS trace element compositions for samples of the Mahogany Mountain rhyolite.

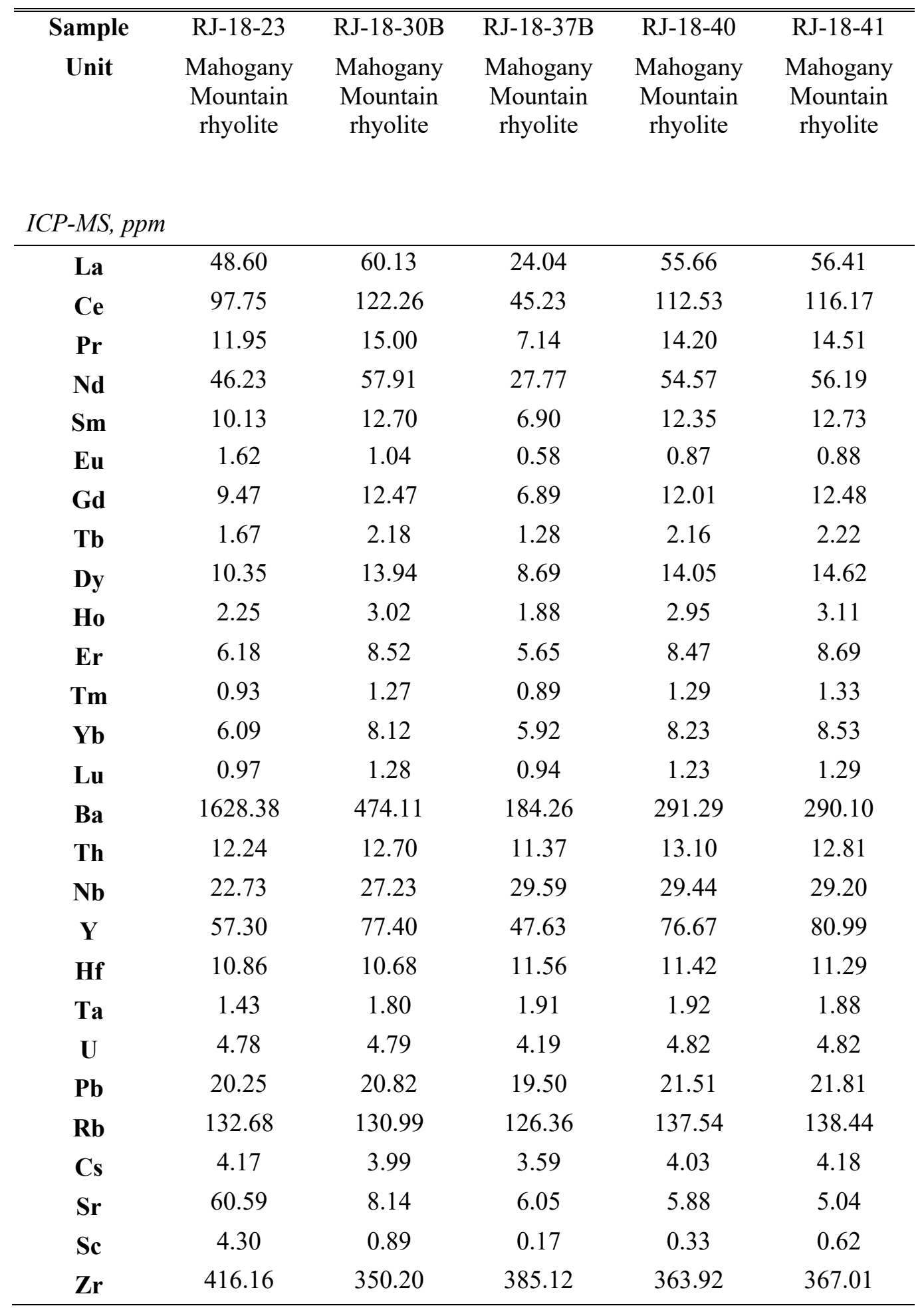


Table 28. ICP-MS trace element compositions for samples of the Mahogany Mountain rhyolite.

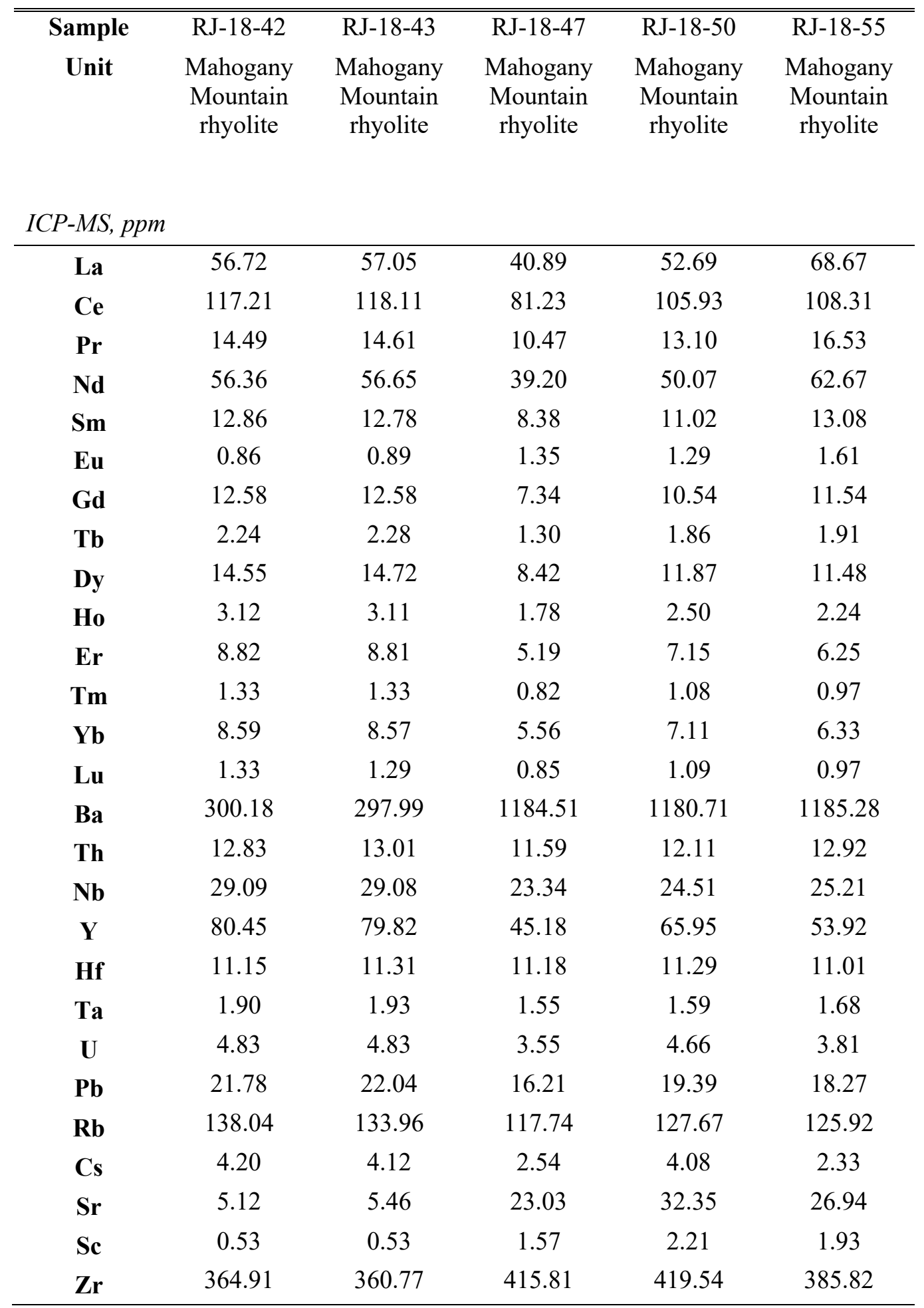


Table 29. ICP-MS trace element compositions for the Mahogany Mountain rhyolite, Tuff of Leslie Gulch, Birch Creek rhyolite, and McCain Creek rhyolite samples.

\begin{tabular}{|c|c|c|c|c|c|c|}
\hline Sample & RJ-18-56 & RJ-18-28 & RJ-18-32 & RJ-18-35 & RJ-18-53 & RJ-18-57 \\
\hline Unit & $\begin{array}{l}\text { Mahogany } \\
\text { Mountain } \\
\text { rhyolite }\end{array}$ & $\begin{array}{l}\text { Tuff of } \\
\text { Leslie } \\
\text { Gulch }\end{array}$ & $\begin{array}{c}\text { Birch } \\
\text { Creek } \\
\text { rhyolite }\end{array}$ & $\begin{array}{l}\text { Birch } \\
\text { Creek } \\
\text { rhyolite }\end{array}$ & $\begin{array}{l}\text { McCain } \\
\text { Creek } \\
\text { rhyolite }\end{array}$ & $\begin{array}{c}\text { McCain } \\
\text { Creek } \\
\text { rhyolite }\end{array}$ \\
\hline \multicolumn{7}{|c|}{$I C P-M S, p p m$} \\
\hline La & 57.84 & 72.52 & 29.34 & 29.74 & 73.99 & 74.14 \\
\hline $\mathrm{Ce}$ & 111.25 & 117.50 & 54.67 & 55.93 & 136.80 & 137.65 \\
\hline $\operatorname{Pr}$ & 14.57 & 16.77 & 6.21 & 6.41 & 15.22 & 15.38 \\
\hline Nd & 54.81 & 71.06 & 22.87 & 23.10 & 53.38 & 54.28 \\
\hline Sm & 11.68 & 15.96 & 4.60 & 4.71 & 10.25 & 10.52 \\
\hline $\mathbf{E u}$ & 1.28 & 4.02 & 0.89 & 0.89 & 1.36 & 1.49 \\
\hline Gd & 10.25 & 18.35 & 4.10 & 4.23 & 8.87 & 8.90 \\
\hline $\mathbf{T b}$ & 1.79 & 2.94 & 0.71 & 0.72 & 1.46 & 1.50 \\
\hline Dy & 11.10 & 18.23 & 4.35 & 4.38 & 8.92 & 9.20 \\
\hline Ho & 2.21 & 4.10 & 0.95 & 0.95 & 1.83 & 1.83 \\
\hline $\mathbf{E r}$ & 6.21 & 11.15 & 2.66 & 2.62 & 5.03 & 5.12 \\
\hline $\mathbf{T m}$ & 0.95 & 1.56 & 0.41 & 0.41 & 0.75 & 0.76 \\
\hline $\mathbf{Y b}$ & 5.95 & 9.33 & 2.77 & 2.77 & 4.80 & 4.72 \\
\hline $\mathbf{L u}$ & 0.90 & 1.52 & 0.44 & 0.45 & 0.71 & 0.72 \\
\hline $\mathbf{B a}$ & 1116.38 & 1053.94 & 1113.33 & 1255.76 & 1331.05 & 1520.74 \\
\hline Th & 13.48 & 5.81 & 7.61 & 7.88 & 27.03 & 27.38 \\
\hline $\mathbf{N b}$ & 25.69 & 19.44 & 11.26 & 11.64 & 29.99 & 29.78 \\
\hline $\mathbf{Y}$ & 54.57 & 125.79 & 24.72 & 25.55 & 47.98 & 48.84 \\
\hline Hf & 11.10 & 8.17 & 5.35 & 5.58 & 13.56 & 13.26 \\
\hline $\mathbf{T a}$ & 1.69 & 1.04 & 0.84 & 0.89 & 2.02 & 2.00 \\
\hline $\mathbf{U}$ & 4.15 & 12.47 & 2.99 & 3.04 & 5.85 & 5.93 \\
\hline $\mathbf{P b}$ & 15.19 & 11.55 & 14.35 & 15.00 & 26.87 & 27.55 \\
\hline $\mathbf{R b}$ & 133.46 & 69.02 & 140.26 & 143.52 & 168.28 & 176.97 \\
\hline Cs & 3.19 & 4.80 & 8.15 & 4.45 & 3.04 & 3.10 \\
\hline $\mathrm{Sr}$ & 20.19 & 301.35 & 215.38 & 215.35 & 80.41 & 89.61 \\
\hline Sc & 1.76 & 19.90 & 4.45 & 4.62 & 5.33 & 4.79 \\
\hline $\mathbf{Z r}$ & 387.34 & 343.29 & 195.87 & 202.33 & 528.00 & 521.26 \\
\hline
\end{tabular}




\section{APPENIDX E: OXYGEN ISOTOPES}

\section{Methods}

Oxygen isotope analysis was performed at University of Oregon in the Stable Isotope Laboratory. Analyses were performed on quartz, plagioclase, and alkali feldspar crystals separated from surrounding matrix. Grains were pretreated with 2 Torr $\mathrm{BrF}_{5}$ overnight to remove surface and water contamination. Oxygen was isolated from the sample using laser fluorination with a $35 \mathrm{~W}$ Newwave $\mathrm{CO}_{2} \mathrm{IR}$ laser and $\mathrm{BrF}_{5}$ reagent. Released oxygen gas was analyzed using a Finnigan MAT 253 large radius 10kv gas source mass spectrometer. Ratios for these analyses are shown in Table 4.

Equations (i.e., correction factors) have been developed to convert mineral $\delta^{18} \mathrm{O}$ data to magma $\delta^{18} \mathrm{O}$ (Bindeman et al., 2004). The MELTS program was used to determine how $\delta^{18} \mathrm{O}$ changes with $\mathrm{SiO}_{2}$ to treat melts (i.e., bulk rock) as mixtures of normative minerals. The correction factor for plagioclase, quartz, and alkali feldspar using bulk rock $\mathrm{SiO}_{2}$ concentrations is:

$$
\begin{gathered}
\text { Plagioclase: } \delta^{18} \mathrm{O}_{\text {magma }}=0.027\left(\mathrm{SiO}_{2} \text { wt. } \% \text { whole rock }\right)-1.45+\delta^{18} \mathrm{O}_{\text {plag }} \text { Eq. D-1 } \\
\text { Quartz: } \delta^{18} \mathrm{O}_{\text {magma }}=\delta^{18} \mathrm{O}_{\mathrm{qtz}}-0.45 \text { Eq. D-2 } \\
\text { Alkali-Feldspar: } \delta^{18} \mathrm{O}_{\text {magma }}=\delta^{18} \mathrm{O}_{\text {kspar }}+0.29 \text { Eq. D-3 }
\end{gathered}
$$

with equation D-1 based on calculations by Bindeman et al. (2004), equation D-2 based on measurements in the Bishop Tuff (Bindeman and Valley, 2002), and equation D-3 
based on the average $\delta^{18} \mathrm{O}$, melt-sanidine value for seventeen sanidine crystals analyzed in the Timber Mountain/Oasis Valley Caldera Complex in southwest Nevada (Bindeman and Valley, 2003). Approximate magma $\delta^{18} \mathrm{O}$ values can be determined adding this correction factor to single grain data. This correction factor will not be valid when applied to xenocrysts or crystals involved in magma mixing because the bulk rock $\mathrm{SiO}_{2}$ content is not the same as the melt the minerals crystallized (Bindeman et al., 2004). These equations provide a means for establishing representative interpretations of $\delta^{18} \mathrm{O}$ data for subject magmas prior to eruption. (Table 28).

Single and pairs of feldspar and quartz phenocrysts from each unit were analyzed for ${ }^{18} \mathrm{O} /{ }^{16} \mathrm{O}$ ratios. The $\delta^{18} \mathrm{O}$ magma values calculated for these units using the equations listed above, based on the $\delta^{18} \mathrm{O}$ values of quartz and feldspar phenocrysts. 
Table 30. Analyzed $\delta^{18} \mathrm{OFeldspar} \delta^{18} \mathrm{O}_{\text {Quartz, }}$ and $\delta^{18} \mathrm{O}_{\text {magma values from alkali feldspars and quartz }}$ phenocrysts. All samples were subject to bulk crystal analysis.

\begin{tabular}{|c|c|c|c|c|}
\hline Unit & Sample ID & Mineral & $\bar{~} \delta^{18}$ O SMOW & $\overline{\delta^{18} O \text { Magma }}$ \\
\hline $\begin{array}{c}\text { Birch Creek } \\
\text { Rhyolite }\end{array}$ & RJ-18-32 & Plagioclase & 6.269 & 6.559 \\
\hline \multirow[t]{2}{*}{$\begin{array}{l}\text { Tuff of Leslie } \\
\text { Gulch }\end{array}$} & RJ-18-28 & $\begin{array}{l}\text { Alkali- } \\
\text { Feldspar }\end{array}$ & 5.28 & 5.57 \\
\hline & & Quartz & 7.135 & 6.685 \\
\hline \multirow[t]{2}{*}{$\begin{array}{l}\text { Rhyolite near } \\
\text { Round Mtn }\end{array}$} & RJ-18-05 & $\begin{array}{l}\text { Alkali- } \\
\text { Feldspar }\end{array}$ & 6.152 & 6.442 \\
\hline & & Quartz & 6.528 & 6.078 \\
\hline $\begin{array}{c}\text { Smith Butte } \\
\text { Rhyolite }\end{array}$ & RJ-18-04 & $\begin{array}{l}\text { Alkali- } \\
\text { Feldspar }\end{array}$ & 5.173 & 5.463 \\
\hline \multirow[t]{4}{*}{$\begin{array}{l}\text { Mahogany } \\
\text { Mountain } \\
\text { Rhyolite }\end{array}$} & RJ-18-12A & $\begin{array}{l}\text { Alkali- } \\
\text { Feldspar }\end{array}$ & 5.993 & 6.283 \\
\hline & RJ-18-50 & $\begin{array}{l}\text { Alkali- } \\
\text { Feldspar }\end{array}$ & 6.635 & 6.925 \\
\hline & RJ-18-19 & $\begin{array}{l}\text { Alkali- } \\
\text { Feldspar }\end{array}$ & 6.023 & 6.313 \\
\hline & & Quartz & 6.717 & 6.267 \\
\hline $\begin{array}{c}\text { McCain } \\
\text { Creek } \\
\text { Rhyolite }\end{array}$ & RJ-18-57 & $\begin{array}{l}\text { Alkali- } \\
\text { Feldspar }\end{array}$ & 3.881 & 4.171 \\
\hline
\end{tabular}


Table 31. Unnormalized chemical data acquired using scanning electron microscopy of ' Rhyolite SE of Round Mountain, sample RJ-18-05. Reported here are atomic and weight percent averages for compositions of targeted phenocrysts.

\begin{tabular}{|c|c|c|c|c|c|c|c|c|c|c|c|}
\hline \multicolumn{12}{|c|}{ Rhyolite SE of Round Mtn: RJ-18-05 } \\
\hline \multirow[b]{2}{*}{ Element } & \multicolumn{2}{|c|}{ Feldspar } & \multirow[b]{2}{*}{ Element } & \multicolumn{2}{|c|}{ Clinopyroxene } & \multirow{2}{*}{ Element } & \multicolumn{2}{|c|}{ Fe-Ti oxides } & \multirow[b]{2}{*}{ Element } & \multicolumn{2}{|c|}{ Zircon } \\
\hline & $\underset{\%}{\operatorname{Atomic}}$ & Wt. \% & & Atomic \% & Wt. \% & & $\underset{\%}{\text { Atomic }}$ & $\begin{array}{l}\text { Wt. } \\
\%\end{array}$ & & $\underset{\%}{\operatorname{Atomic}}$ & $\begin{array}{l}\text { Wt. } \\
\mathbf{\%} \%\end{array}$ \\
\hline $\mathbf{O}$ & 61.72 & 45.84 & $\mathbf{O}$ & 60.05 & 41.47 & $\mathbf{O}$ & 54.87 & 26.34 & $\mathbf{O}$ & 66.67 & 35.5 \\
\hline $\mathrm{Na}$ & 3.57 & 3.81 & Mg & 4.01 & 4.17 & Al & 0.83 & 0.67 & $\mathbf{S i}$ & 16.27 & $\begin{array}{c}15.2 \\
1\end{array}$ \\
\hline Al & 7.72 & 9.67 & Al & 0.24 & 0.28 & $\mathbf{S i}$ & 1.03 & 0.87 & $\mathbf{Z r}$ & 17.06 & $\begin{array}{c}51.7 \\
9\end{array}$ \\
\hline $\mathbf{S i}$ & 23.17 & 30.21 & $\mathbf{S i}$ & 20.03 & 24.26 & $\mathbf{T i}$ & 8.24 & 11.87 & & & \\
\hline $\mathbf{K}$ & 3.63 & 6.58 & $\mathbf{C a}$ & 7.76 & 13.49 & $\mathbf{V}$ & 0.17 & 0.25 & & & \\
\hline $\mathrm{Ca}$ & 0.14 & 0.26 & Mn & 0.29 & 0.70 & Mn & 0.88 & 1.42 & & & \\
\hline $\mathrm{Fe}$ & 0.05 & 0.13 & $\mathrm{Fe}$ & 7.72 & 18.54 & $\mathrm{Fe}$ & 33.68 & 56.37 & & & \\
\hline Ba & 0.02 & 0.11 & & & & $\mathbf{Z n}$ & 0.75 & 1.50 & & & \\
\hline
\end{tabular}

$\stackrel{p}{ \pm}$ 
Table 32. Unnormalized chemical data acquired using scanning electron microscopy of Smith Butte rhyolite sample RJ-18-04. Reported here are atomic and weight percent averages for compositions of targeted phenocrysts.

Smith Butte rhyolite: RJ-18-04

\begin{tabular}{ccc}
\hline & \multicolumn{3}{c}{ Feldspar } \\
\cline { 2 - 3 } Element & Atomic \% & Wt. \% \\
\hline $\mathbf{O}$ & 61.69 & 45.85 \\
$\mathbf{N a}$ & 3.60 & 3.85 \\
$\mathbf{A l}$ & 7.79 & 9.76 \\
$\mathbf{S i}$ & 23.08 & 30.12 \\
$\mathbf{K}$ & 3.60 & 6.53 \\
$\mathbf{C a}$ & 0.16 & 0.30 \\
$\mathbf{F e}$ & 0.05 & 0.14 \\
$\mathbf{B a}$ & 0.02 & 0.16 \\
\hline
\end{tabular}

Table 33. Unnormalized chemical data acquired using scanning electron microscopy of ash-flow tuff sample RJ-18-28. Reported here are atomic and weight percent averages for compositions of targeted phenocrysts.

Ash-flow tuff (cTLG): RJ-18-28

Feldspar

\begin{tabular}{ccc}
\cline { 2 - 3 } Element & Atomic \% & Wt. \% \\
\hline $\mathbf{O}$ & 62.05 & 48.36 \\
$\mathbf{N a}$ & 3.25 & 3.63 \\
$\mathbf{A l}$ & 9.45 & 12.38 \\
$\mathbf{S i}$ & 21.64 & 29.66 \\
$\mathbf{K}$ & 1.81 & 3.48 \\
$\mathbf{C a}$ & 4.06 & 7.86 \\
\hline
\end{tabular}


Table 34. Unnormalized chemical data acquired using scanning electron microscopy of Mahogany Mountain rhyolite sample RJ18-11. Reported here are atomic and weight percent averages for compositions of targeted phenocrysts.

\begin{tabular}{|c|c|c|c|c|c|c|c|c|c|c|c|}
\hline \multicolumn{12}{|c|}{ Mahogany Mtn rhyolite Flow Unit 1: RJ-18-11 } \\
\hline \multirow[b]{2}{*}{ Element } & \multicolumn{2}{|c|}{ Feldspar } & \multirow[b]{2}{*}{ Element } & \multicolumn{2}{|c|}{ Clinopyroxene } & \multirow[b]{2}{*}{ Element } & \multicolumn{2}{|c|}{ Fe-Ti oxides } & \multirow[b]{2}{*}{ Element } & \multicolumn{2}{|c|}{ Zircon } \\
\hline & $\begin{array}{c}\text { Atomic } \\
\%\end{array}$ & Wt. \% & & Atomic \% & Wt. \% & & $\begin{array}{c}\text { Atomic } \\
\%\end{array}$ & $\begin{array}{l}\text { Wt. } \\
\%\end{array}$ & & $\begin{array}{c}\text { Atomic } \\
\%\end{array}$ & $\begin{array}{l}\text { Wt. } \\
\%\end{array}$ \\
\hline $\mathbf{O}$ & 61.65 & 47.74 & $\mathbf{O}$ & 61.71 & 43.09 & $\mathbf{O}$ & 57.73 & 29.46 & $\mathbf{O}$ & 66.67 & 35.14 \\
\hline $\mathbf{N a}$ & 5.15 & 5.73 & Mg & 0.79 & 0.84 & Al & 0.84 & 0.72 & $\mathbf{S i}$ & 16.21 & 15.00 \\
\hline Al & 9.56 & 12.48 & Al & 4.83 & 5.68 & $\mathrm{Si}$ & 2.13 & 1.91 & $\mathbf{Z r}$ & 17.06 & 51.45 \\
\hline Si & 21.32 & 28.98 & Si & 21.44 & 26.27 & $\mathbf{T i}$ & & 19.74 & & & \\
\hline \multirow[t]{3}{*}{$\mathbf{K}$} & 0.47 & 0.89 & $\mathbf{K}$ & 0.85 & 1.46 & Mn & & 1.71 & & & \\
\hline & & & $\mathbf{C a}$ & & 1.82 & $\mathrm{Fe}$ & & 45.25 & & & \\
\hline & & & $\mathrm{Fe}$ & & 22.79 & & & & & & \\
\hline
\end{tabular}


Table 35. Unnormalized chemical data acquired using scanning electron microscopy of Mahogany Mountain rhyolite sample RJ-18-50. Reported here are atomic and weight percent averages for compositions of targeted phenocrysts.

\begin{tabular}{|c|c|c|c|c|c|c|c|c|}
\hline \multicolumn{9}{|c|}{ Mahogany Mtn rhyolite Flow Unit 2: RJ-18-50 } \\
\hline \multirow[b]{2}{*}{ Element } & \multicolumn{2}{|c|}{ Feldspar } & \multirow[b]{2}{*}{ Element } & \multicolumn{2}{|c|}{ Clinopyroxene } & \multirow[b]{2}{*}{ Element } & \multicolumn{2}{|c|}{ Zircon } \\
\hline & $\begin{array}{c}\text { Atomic } \\
\%\end{array}$ & Wt. \% & & Atomic \% & Wt. \% & & $\begin{array}{c}\text { Atomic } \\
\%\end{array}$ & $\begin{array}{l}\text { Wt. } \\
\%\end{array}$ \\
\hline $\mathbf{O}$ & 61.71 & 47.41 & $\mathbf{O}$ & 63.62 & 46.05 & $\mathbf{O}$ & 66.67 & 34.88 \\
\hline $\mathrm{Na}$ & 4.60 & 5.09 & Mg & 0.57 & 0.63 & $\mathbf{S i}$ & 16.26 & 14.94 \\
\hline Al & 8.39 & 10.87 & Al & 3.22 & 3.92 & $\mathbf{Z r}$ & 17.07 & 50.92 \\
\hline Si & 22.56 & 30.43 & $\mathbf{S i}$ & 25.96 & 32.99 & & & \\
\hline $\mathbf{K}$ & 2.06 & 3.87 & $\mathbf{K}$ & 0.66 & 1.16 & & & \\
\hline $\mathrm{Ca}$ & 0.59 & 1.14 & $\mathrm{Ca}$ & 1.02 & 1.86 & & & \\
\hline $\mathbf{B a}$ & 0.23 & 1.50 & $\mathrm{Fe}$ & 4.94 & 12.50 & & & \\
\hline
\end{tabular}


Table 36. Unnormalized chemical data acquired using scanning electron microscopy of Mahogany Mountain rhyolite sample RJ-1819. Reported here are atomic and weight percent averages for compositions of targeted phenocrysts. Clinopyroxene data of this sample was collected using an electron microprobe by Martin Streck.

\begin{tabular}{|c|c|c|c|c|c|c|c|c|c|c|}
\hline \multicolumn{11}{|c|}{ Mahogany Mtn rhyolite Flow Unit 3: RJ-18-19 } \\
\hline \multirow[b]{2}{*}{ Element } & \multicolumn{2}{|c|}{ Feldspar } & \multirow[b]{2}{*}{ Element } & \multirow{2}{*}{$\begin{array}{c}\text { Clinopyroxene* } \\
\text { Atomic \% }\end{array}$} & \multirow[b]{2}{*}{ Element } & \multicolumn{2}{|c|}{ Fe-Ti oxides } & \multirow[b]{2}{*}{ Element } & \multicolumn{2}{|c|}{ Zircon } \\
\hline & $\begin{array}{c}\text { Atomic } \\
\%\end{array}$ & Wt. $\%$ & & & & $\underset{\%}{\text { Atomic }}$ & $\begin{array}{l}\text { Wt. } \\
\%\end{array}$ & & $\begin{array}{c}\text { Atomic } \\
\%\end{array}$ & $\begin{array}{l}\text { Wt. } \\
\%\end{array}$ \\
\hline $\mathbf{O}$ & 61.76 & 47.66 & $\mathrm{SiO}_{2}$ & 47.58 & $\mathbf{O}$ & 62.77 & 38.94 & $\mathbf{O}$ & 66.67 & 33.2 \\
\hline $\mathbf{N a}$ & 3.84 & 4.25 & $\mathrm{TiO}_{2}$ & 0.23 & Al & 0.48 & 0.51 & $\mathbf{S i}$ & 16.16 & 14.13 \\
\hline Al & 7.67 & 9.98 & $\mathrm{Al}_{2} \mathbf{O}_{3}$ & 0.27 & $\mathbf{S i}$ & 14.3 & 15.57 & $\mathbf{Z r}$ & 17.17 & 48.76 \\
\hline $\mathbf{S i}$ & 23.31 & 31.58 & $\mathrm{FeO}$ & 30.91 & $\mathrm{Ca}$ & 2.78 & 4.32 & & & \\
\hline \multirow[t]{6}{*}{$\mathbf{K}$} & 3.43 & 6.46 & MnO & 0.98 & $\mathbf{T i}$ & 10.99 & 20.42 & & & \\
\hline & & & MgO & 0.06 & $\mathrm{Fe}$ & 8.68 & 18.8 & & & \\
\hline & & & $\mathrm{CaO}$ & 18.93 & & & & & & \\
\hline & & & $\mathrm{Na}_{2} \mathrm{O}$ & 0.43 & & & & & & \\
\hline & & & $\mathrm{NiO}$ & 0.01 & & & & & & \\
\hline & & & $\mathrm{ZnO}$ & 0.13 & & & & & & \\
\hline
\end{tabular}


Table 37. Unnormalized chemical data acquired using scanning electron microscopy of Bannock Ridge rhyolite, sample RJ-18-02. Reported here are atomic and weight percent averages for measured elements of targeted minerals. Clinopyroxene data of was collected from Bannock Ridge rhyolite sample RJ-18-15, using an electron microprobe by Martin Streck.

Bannock Ridge rhyolite

\begin{tabular}{cccccc}
\hline & \multicolumn{3}{c}{ Feldspar } & & Clinopyroxene \\
\cline { 2 - 3 } Element & Atomic \% & Wt. \% & Element & Atomic \% \\
\hline $\mathbf{O}$ & 61.93 & 46.45 & $\mathbf{S i O}_{2}$ & 47.31 \\
$\mathbf{N a}$ & 4.87 & 5.25 & & $\mathbf{T i O}_{2}$ & 0.37 \\
$\mathbf{A l}$ & 8.40 & 10.62 & & $\mathbf{A l}_{2} \mathbf{O}_{3}$ & 0.61 \\
$\mathbf{S i}$ & 22.58 & 29.74 & & $\mathbf{F e O}$ & 30.73 \\
$\mathbf{K}$ & 0.95 & 1.73 & $\mathbf{M n O}$ & 1.12 \\
$\mathbf{C a}$ & 1.07 & 2.01 & $\mathbf{M g O}$ & 0.30 \\
$\mathbf{F e}$ & 0.10 & 0.27 & $\mathbf{C a O}$ & 18.85 \\
$\mathbf{B a}$ & 0.09 & 0.57 & $\mathbf{N a 2}$ & 0.26 \\
& & & $\mathbf{N i O}$ & 0.01 \\
& & & $\mathbf{Z n O}$ & 0.10 \\
\hline
\end{tabular}

Table 38. Unnormalized chemical data acquired using scanning electron microscopy of Birch Creek rhyolite, sample RJ-18-35. Reported here are atomic and weight percent averages for measured elements of targeted minerals.

Birch Creek rhyolite: RJ-18-35

\begin{tabular}{ccc}
\hline & \multicolumn{2}{c}{ Feldspar } \\
\cline { 2 - 3 } Element & Atomic \% & Wt. \% \\
\hline $\mathbf{O}$ & 61.67 & 48.07 \\
$\mathbf{N a}$ & 4.55 & 5.10 \\
$\mathbf{A l}$ & 10.14 & 13.33 \\
$\mathbf{S i}$ & 20.74 & 28.38 \\
$\mathbf{K}$ & 0.39 & 0.74 \\
$\mathbf{C a}$ & 2.51 & 4.89 \\
\hline
\end{tabular}


Table 39. Unnormalized chemical data acquired using scanning electron microscopy of McCain Creek rhyolite, sample RJ-18-57. Reported here are atomic and weight percent averages for measured elements of targeted minerals. Clinopyroxene data of this sample was collected using an electron microprobe by Martin Streck.

McCain Creek rhyolite: RJ-18-57

\begin{tabular}{|c|c|c|c|c|c|c|c|}
\hline \multirow[b]{2}{*}{ Element } & \multicolumn{2}{|c|}{ Feldspar } & \multirow[b]{2}{*}{ Element } & \multirow{2}{*}{$\begin{array}{c}\text { Clinopyroxene* } \\
\text { Atomic \% }\end{array}$} & \multirow[b]{2}{*}{ Element } & \multicolumn{2}{|c|}{ Fe-Ti oxides } \\
\hline & Atomic \% & Wt. \% & & & & $\begin{array}{c}\text { Atomic } \\
\%\end{array}$ & Wt. \% \\
\hline $\mathbf{O}$ & 61.69 & 47.48 & $\mathrm{SiO}_{2}$ & 49.82 & $\mathbf{O}$ & 59.61 & 32.91 \\
\hline $\mathbf{N a}$ & 3.73 & 4.16 & $\mathrm{TiO}_{2}$ & 0.23 & Mg & 0.8 & 0.67 \\
\hline Al & 8.83 & 11.49 & $\mathrm{Al}_{2} \mathrm{O}_{3}$ & 0.57 & $\mathbf{T i}$ & 19.21 & 31.76 \\
\hline $\mathbf{S i}$ & 22.05 & 29.76 & $\mathrm{FeO}$ & 27.98 & Mn & 0.34 & 0.65 \\
\hline $\mathbf{K}$ & 2.43 & 4.47 & MnO & 0.75 & $\mathrm{Fe}$ & 20.04 & 38.62 \\
\hline $\mathrm{Ca}$ & 1.18 & 2.32 & MgO & 9.74 & & & \\
\hline \multirow[t]{4}{*}{$\mathbf{B a}$} & 0.23 & 1.44 & $\mathrm{CaO}$ & 10.91 & & & \\
\hline & & & $\mathrm{Na}_{2} \mathbf{O}$ & 0.16 & & & \\
\hline & & & $\mathrm{NiO}$ & 0.01 & & & \\
\hline & & & $\mathrm{ZnO}$ & 0.10 & & & \\
\hline
\end{tabular}




\section{APPENDIX G: Geologic Map with Sample Locations}

Figure 91. Geologic map I generated with marked sample locations for units of this study, denoted by $X$ 's. Map projection and datum are in North American Datum 1983.

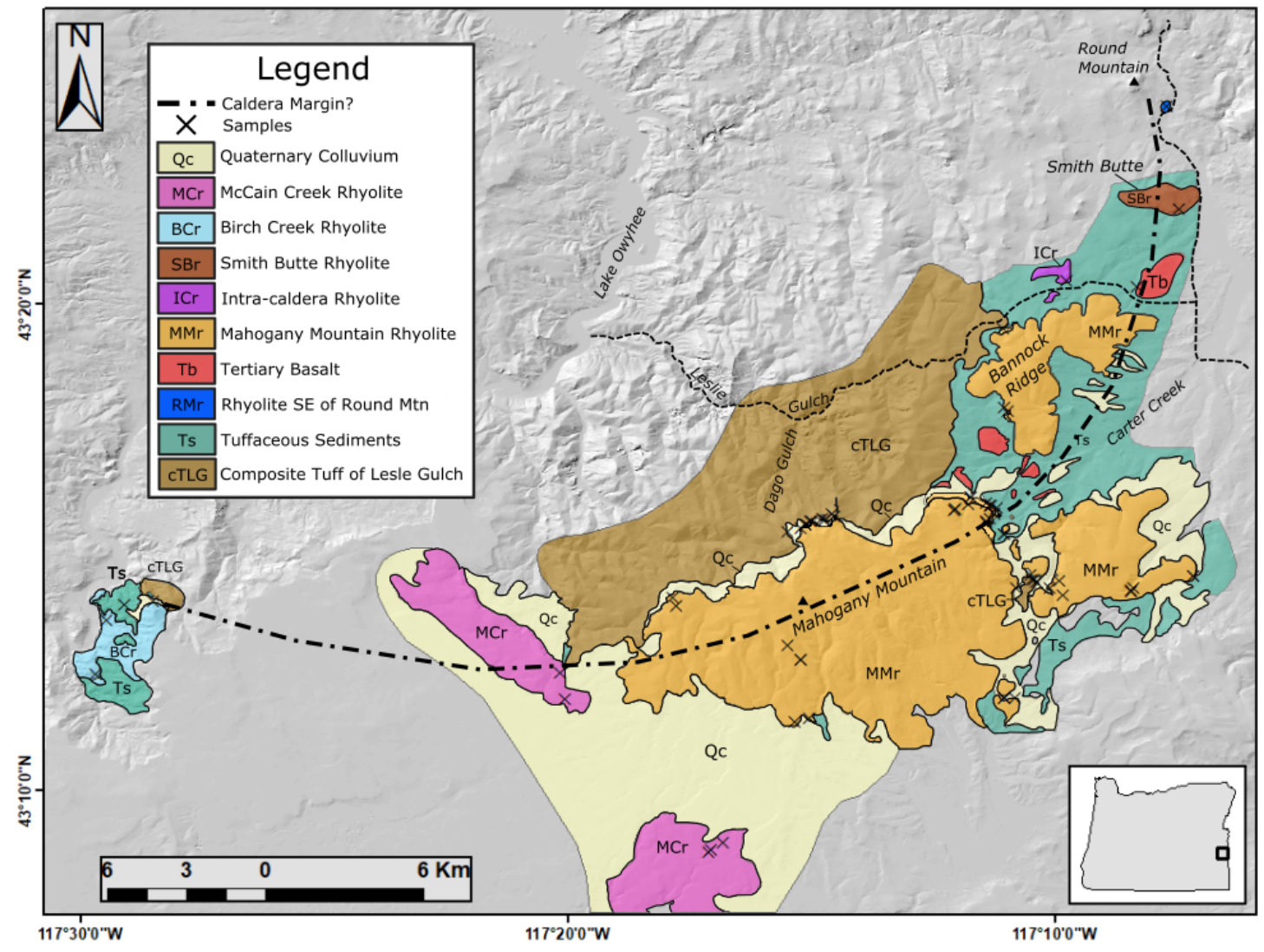




\section{APPENDIX H: Partition Coefficients used in Geochemical Modeling}

Table 40. Partition coefficients for trace elements used in geochemical modeling for rhyolites of this study, separated by respective mineral.

\begin{tabular}{c|c|c|c|c|c|c|c}
\multicolumn{6}{c}{ study, separated by respective mineral. } \\
\multicolumn{2}{c}{ Plagioclase } & $\begin{array}{c}\text { Alkali } \\
\text { Feldspar }\end{array}$ & Quartz & Clinopyroxene & $\begin{array}{c}\text { Fe-Ti } \\
\text { oxides }\end{array}$ & Zircon & Apatite \\
\hline $\mathrm{Rb}$ & 0.02 & 0.2 & 0.005 & 0.01 & 0.05 & 0.05 & 1.5 \\
$\mathrm{Ba}$ & 0.5 & 7 & 0.005 & 0.01 & 0.005 & 0.005 & 0.2 \\
$\mathrm{Th}$ & 0.01 & 0.03 & 0.005 & 0.01 & 0.08 & 41.84 & 1 \\
$\mathrm{U}$ & 0.01 & 0.055 & 0.005 & 0.01 & 0.08 & 192.05 & 1 \\
$\mathrm{Nb}$ & 0.01 & 0.03275 & 0.005 & 0.009 & 1.2 & 1.08 & 1.7 \\
$\mathrm{Ta}$ & 0.01 & 0.047 & 0.005 & 0.009 & 1.4 & 2 & 0.2 \\
$\mathrm{La}$ & 0.3 & 0.138 & 0.005 & 0.2 & 0.22 & 0.24 & 46.2 \\
$\mathrm{Ce}$ & 0.2 & 0.06 & 0.005 & 0.5 & 0.2 & 0.54 & 65.7 \\
$\mathrm{~Pb}$ & 0.4 & 0.8 & 0.005 & 0.03 & 0.1 & 0.1 & 0.2 \\
$\mathrm{Pr}$ & 0.18 & 0.048 & 0.005 & 1 & 0.17 & 0.5 & 70 \\
$\mathrm{Sr}$ & 6 & 11.8 & 0.005 & 0.25 & 0.01 & 0.01 & 2 \\
$\mathrm{Nd}$ & 0.15 & 0.035 & 0.005 & 2 & 0.15 & 0.68 & 101.5 \\
$\mathrm{Zr}$ & 0.01 & 0.03 & 0.005 & 0.2 & 0.8 & 3224.17 & 0.6 \\
$\mathrm{Hf}$ & 0.01 & 0.036 & 0.005 & 0.2 & 0.75 & 1589.76 & 0.7 \\
$\mathrm{Sm}$ & 0.1 & 0.02 & 0.005 & 4 & 0.11 & 3.42 & 130 \\
$\mathrm{Eu}$ & 2.5 & 4.75 & 0.005 & 4.8 & 0.13 & 2.42 & 155 \\
$\mathrm{~Tb}$ & 0.08 & 0.024 & 0.005 & 5.5 & 0.08 & 33.69 & 110 \\
$\mathrm{Dy}$ & 0.07 & 0.024 & 0.005 & 5 & 0.09 & 64.89 & 76.2 \\
$\mathrm{Y}$ & 0.07 & 0.05 & 0.005 & 4.8 & 0.09 & 106.45 & 162 \\
$\mathrm{Yb}$ & 0.07 & 0.02 & 0.005 & 3.8 & 0.09 & 385.75 & 40 \\
$\mathrm{Lu}$ & 0.07 & 0.016 & 0.005 & 3.6 & 0.1 & 0.1 & 20 \\
\hline & & & & & & \\
\hline
\end{tabular}

\begin{tabular}{|l|}
\hline Bacon \& Druitt, 1988 \\
\hline Bea et al. (1994) \\
\hline Broderick (2008) \\
\hline Brown (2013) \\
\hline Brown (2017) \\
\hline Streck \& Grunder (1997) \\
\hline Streck, unpublished data \\
\hline
\end{tabular}

